\title{
SISTEMA ASSOCIATIVO DE SANEAMENTO E SEUS EFEITOS SOBRE A POPULAÇÃO EM COMUNIDADES DO SEMI-ÁRIDO BAIANO
}

\section{SILVIO ROBERTO MAGALHÃES ORRICO}

Tese de Doutorado apresentada ao Departamento de Saúde Ambiental da Faculdade de Saúde Pública da Universidade de São Paulo para obtenção do Grau de Doutor

Área de concentração:

Saúde Ambiental

Orientadora

Prof Dra Wanda Maria Risso Günther

SĀO PAULO 2003 
Autorizo, exclusivamente para fins acadêmicos e científicos, a reprodução total ou parcial desta tese, por processos fotocopiadores.

Assinatura: $\mathrm{N}$ Robet Ono

Data: $\quad 1+/ 06 / 2003$

4428212003 doc 


\section{DEDICATÓRIA}

Dedico esse trabalho à minha esposa Glória e aos meus filhos Gustavo e Gabriel 


\title{
AGRADECIMENTOS
}

\begin{abstract}
À Universidade Estadual de Feira de Santana e ao Departamento de Tecnologia pela viabilização deste Doutorado.
\end{abstract}

À minha orientadora, Prof ${ }^{a}$ Wanda Risso Günther, pelo seu apoio, confiança e paciência com as minhas questões.

Às coordenações do Doutorado Interinstitucional nas pessoas do Prof. Paulo Fortes, da Prof ${ }^{a}$ Evelyn Naked de Castro Sá e do Prof. Guido Rummler, bem como aos professores e orientadores deste Doutorado pelas suas colaborações.

Aos professores Carlos Celso do Amaral, Bernardo Teixeira e Roque Piveli da banca examinadora as quais ajudaram a melhorar este trabalho.

Ao Prof. Ricardo Bernades, com ajuda e a sua forma especial de ver o mundo e as pessoas.

Ao Prof. Moraes, pelo seu estímulo, disponibilidade, exemplo de valores e apoio neste trabalho e na vida profissional.

Sou muito grato à minha mãe, meus irmãos, José, Dantinho e Christina e à minha cunhada Evelyn pelas suas ajudas.

Aos consultores do Banco KfW, Marjo e Hans, pelas informações e apoio ao trabalho e aos funcionários da Central II, Diana, Antônio, Renê e Fábio, que sempre atenderam com gentileza meus pedidos de informações e de materiais 
À equipe de trabalho da CERB nas pessoas de Fátima, Auxiliadora, Jorge, Irinalvo, Rosana, Cirlene, João Lopes e Milton Sodré e aos amigos Picasso Fabrício, Paulo Grisi e Cynthia pelos vários tipos de ajudas.

Aos colegas do curso, em especial a Adélia, Cristina, Maridalva e Sandra com seus apoios nos momentos certos.

Aos estagiários Tiago e Mariane pela dedicação na produção do trabalho.

E por fim a Deus por todas as suas formas de nos ensinar a viver. 


\section{RESUMO}

Orrico SRM. Sistema associativo de saneamento e seus efeitos sobre a população em comunidades do semi-árido baiano. São Paulo; 2003 [Tese de Doutorado - Faculdade de Saúde Pública da USP].

Este trabalho apresenta um estudo sobre saneamento em seis localidades de pequeno porte no semi-árido baiano, onde foram implantados sistemas de abastecimento de água e de esgotamento sanitário dentro de uma ótica de tecnologia apropriada à realidade sócio econômica da região, incluindo nesse caso a educação sanitária, participação da comunidade e projetos de baixo custo de implantação e de simples operação e manutenção. Estas duas últimas, a cargo das associações locais e da federação das mesmas (Central II). $O$ objetivo foi analisar os efeitos da implantação dos sistemas de saneamento na população por meio de entrevistas e de coleta de dados secundários, e as tecnologias utilizadas nesses sistemas.

Verificou-se o aumento do consumo de água per capita de 21L/hab.dia para 63L/hab.dia e redução de $60 \%$ do desembolso mensal familiar para compra da água. A frequência de hábitos adequadamente sanitários passou de $27 \%$ para $70 \%$, em especial a prática do uso do sanitário, superior a $90 \%$. A população aponta como principais vantagens decorrentes da implantação desses sistemas a eliminação do tempo anteriormente gasto para a busca da água ( 1 hora e 20 minutos por dia), as dores na coluna vertebral e a valorização de aproximadamente $50 \%$ do imóvel. Foi verificada, também, uma redução de $28,6 \%$ dos casos de diarréia em crianças de até 2 anos. A adesão ao sistema é superior $98 \%$ com uma taxa de inadimplência de $2 \%$. O modelo adotado fortaleceu as associações locais que implantaram outras atividades comunitárias. Os benefícios à população nos aspectos de saúde, como de conforto e de economia promovem uma melhoria na qualidade de vida dos moradores dessas comunidades e justificam esse investimento.

Descritores: Saneamento Rural, Tecnologia Apropriada, Abastecimento de Água, e Esgotamento Sanitário, Qualidade de Vida. 


\section{SUMMARY}

Orrico SRM. Sistema associativo de saneamento e seus efeitos sobre a população em comunidades do semi-árido baiano [Associative Sanitation

system and their effects on population of communities in semi arid of Bahia state]. São Paulo (BR); 2003 [Tese de Doutorado - Faculdade de Saúde Pública da USP].

This work shows the study of sanitation improvement project in 6 small communities located in the semi-arid region of Bahia, with a population size of 450 to 2,500 inhabitants and an average precipitation of $600 \mathrm{~mm} /$ year. Water supply and sewerage systems based on appropriated technology were installed, after initiatives on education; community involving decision making processes. The management model is a partnership between the resident association of each community that operates the system and a pool of these associations that undertakes the maintenance of the system.

Operation of these systems resulted in water consumption increasing from $21 \mathrm{~L}$ person.day to $6321 \mathrm{~L}$ person.day and a reduced family monthly payment of $60 \%$ for water. People who were surveyed indicated that one of the most important benefits was the time saved to collect and carry water (on average 1 hour and 20 minutes), back pain and an increase in value of their house. The incidence of diarrhoea in infants younger than 2 years old also decreased $28,6 \%$. The use of water in washing hands/flushing toilets etc increased from $27 \%$ to $70 \%$ and the use of toilet is now above $98 \%$.

Despite the low income of the population, the low cost operation and simple maintenance ensures that the majority of the houses $(98 \%)$ are connected to the system and of these less than $2 \%$ have not paid the tax regularly. In addition the local associations have added new communal activities after operating system. Capital costs cannot be included in the water tax, however, but health benefits and the standard of living of rural people justify this kind of investment by the Government.

Descriptors: Sanitation, Appropriated Technology, Water Supply and sewerage systems. 


\section{ÍNDICE DE FIGURAS}

Figura 1 Ponto de abastecimento para população no meio disperso e para caminhão pipa.

Figura 2 Mapa do estado da Bahia com indicação das localidades da pesquisa................................................................... 41

Figura 3 Vista parcial de Vila Cardoso......................................... 45

Figura 4 Vista parcial de Gameleira 46

Figura 5 Aguada utilizada anteriormente pela população de Gameleira.................................................................. 46

Figura 6 Aguadeiros em Gameleira.............................................. 47

Figura 7 Vista parcial de Jacunã................................................. 48

Figura 8 Moradora de Jacunã coletando água de chuva acumulada em uma depressão da pedra........................... 48

Figura 9 Critérios para escolha do síndico da quadra do esgotamento condominial em Vila Cardoso definidos em reunião da comunidade.................................................... 56

Figura 10 Reunião da Comunidade em Vila Cardoso........................ 56

Figura 11 Estação de Tratamento de Água com Filtro Lento para Piaus e Taquari.............................................................. 64

Figura 12 Tanque Imhoff e wetland e campo de irrigação.................. 66

Figura 13 Lagoa de Estabilização de Jacunã.................................. 67

Figura 14 Estação de Tratamento de Esgoto de Lajinha, rio do Aipim e vista parcial da localidade.

Figura 15 Croqui da localidade de Vila Cardoso com rede básica de abastecimento de água e de esgotamento sanitário......... 75

Figura 16 Croqui da localidade de Gameleira com rede básica de esgotamento sanitário..................................................... 76

Figura 17 Croqui da localidade de Jacunã com rede básica de esgotamento sanitário.

Figura 18 Croqui da localidade de Piaus com rede básica de esgotamento sanitário 
Figura 19 Croqui da localidade de Taquari com rede básica de esgotamento sanitário.

Figura 20 Croqui da localidade de Lajinha com rede básica de esgotamento sanitário.

Figura 21 Criança em Gameleira carregando uma lata de água na cabeça.

Figura 22 Moradora de Jacunã transportando água da aguada........ 90

Figura 23 Armazenamento da água antes do saneamento, segundo frequência, níveis de saneamento e localidades do semiárido baiano, 2002 ......................................................... 95

Figura 24 Armazenamento da água depois do saneamento, segundo frequência, níveis de saneamento e localidades do semiárido baiano, 2002 ...............................................

Figura 25 Origem da água de beber antes do saneamento, segundo frequência, níveis de saneamento e localidades do semiárido baiano, 2002

Figura 26 Origem da água de beber depois do saneamento, segundo frequência, niveis de saneamento e localidades do semiárido baiano, 2002

Figura 27 Tipo de tratamento de água antes do saneamento, segundo frequência, níveis de saneamento e localidades do semi-árido baiano, 2002 .............................................. 96

Figura 28 Tipo de tratamento de água depois do saneamento, segundo frequência, níveis de saneamento e localidades do semi-árido baiano, 2002

Figura 29 Local de lavagem de alimentos antes do saneamento, segundo frequência, níveis de saneamento e localidades do semi-árido baiano, 2002

Figura 30 Local de lavagem de alimentos depois do saneamento, segundo frequência, níveis de saneamento e localidades do semi-árido baiano, 2002 
Figura 31 Local de lavagem dos utensílios domésticos antes do saneamento, segundo frequência, níveis de saneamento e localidades do semi-árido baiano, 2002......................... 97

Figura 32 Local de lavagem dos utensílios domésticos depois do saneamento, segundo frequência, níveis de saneamento e localidades do semi-árido baiano, 2002.......................... 97

Figura 33 Local de lavagem das mãos antes do saneamento, segundo frequência, níveis de saneamento e localidades do semi-árido baiano, 2002 ............................................ 97

Figura 34 Local de lavagem das mãos depois do saneamento, segundo frequência, níveis de saneamento e localidades do semi-árido baiano, 2002

Figura 35 Local de lavagem de roupas antes do saneamento, segundo frequência, níveis de saneamento e localidades do semi-árido baiano, 2002.

Figura 36 Local de lavagem das roupas depois do saneamento, segundo frequência, níveis de saneamento e localidades do semi-árido baiano, 2002.

Figura 37 Local de banho antes do saneamento, segundo frequência, níveis de saneamento e localidades do semi-árido baiano, 2002.

Figura 38 Local de banho depois do saneamento, segundo frequência, níveis de saneamento e localidades do semiárido baiano, 2002

Figura 39 Local utilizado para defecar antes do saneamento, segundo frequência, níveis de saneamento e localidades do semi-árido baiano, 2002.

Figura 40 Local utilizado para defecar depois do saneamento, segundo frequência, niveis de saneamento e localidades do semi-árido baiano, 2002 
Figura 41 Práticas sanitárias antes do saneamento segundo frequência, níveis de saneamento e localidades do semiárido baiano, 2002.......................................................... 99

Figura 42 Práticas sanitárias depois do saneamento segundo frequência, níveis de saneamento e localidades do semiárido baiano, 2002 ...........................................................

Figura 43 Incidência média anual da diarréia infantil no período de abril a setembro de 1999 (antes do saneamento) e de outubro de 1999 a setembro de 2000, em Vila Cardoso e demais localidade do município de Caém-BA................... 10

Figura 44 Incidência média semestral da diarréia infantil no período de abril de 1999 a setembro de 2000, em Vila Cardoso e demais localidade do município de Caém-BA

Figura 45 Incidência média anual da diarréia infantil no período de setembro a dezembro de 1999, 2000 e 2001, em Lajinha e demais localidades do município de Pindobaçu-BA.

Figura 46 Incidência média semestral de diarréia infantil nos períodos de 2000 e 2001, em Lajinha e demais localidades do município de Pindobaçu - BA

Figura 47 Incidência média anual da diarréia infantil dos períodos de maio a dezembro de 2001 e janeiro a setembro de 2002, em Gameleira, Jacunã e demais localidade do município de Jaguarari-BA

Figura 48 Incidência média de diarréia infantil nos períodos de 6 meses antes e 9 meses depois da implantação do sistema de saneamento segundo localidades das pesquisas e demais localidades das zonas rurais dos respectivos municípios 


\section{ÍNDICE DE TABELAS}

Tabela 1 Localidades da pesquisa e tipos de mananciais existentes... 34

Tabela 2 Informações sócioeconômicas dos municípios de Caém, Itiúba Jaguarari e Pindobaçu, estado da Bahia, 2000. 43

Tabela 3 Tipo de Abastecimento de Água das localidades antes e depois ao programa de Saneamento................................. 51

Tabela 4 Acesso às localidades da pesquisa................................... 52

Tabela 5 Características das adutoras do sistema de abastecimento de água de Gameleira e Jacunã

Tabela 6 Rede de distribuição de água das localidades de Gameleira e Jacunã.

Tabela 7 Rede de distribuição de água das localidades de Piaus e Taquari.

Tabela 8 População das localidades da pesquisa previstas pelos projetos de abastecimento de água e de esgotamento sanitário para início e final de plano e respectivas taxas de crescimento.

Tabela 9 Período de implantação dos SAA e SES das localidades da pesquisa

Tabela 10 Custo em Reais dos sistemas de abastecimento de água das localidades da pesquisa

Tabela 11 População e custo em reais per capita dos sistemas de abastecimento de água das localidades da pesquisa.

Tabela 12 Custo em Reais dos sistemas de esgotamento sanitário das localidades da pesquisa

Tabela 13 População de final de plano e custo em reais per capita dos sistemas de esgotamento sanitário das localidades da pesquisa.

Tabela 14 População de final de plano e custo per capita dos sistemas abastecimento de água e de esgotamento sanitário das localidades da pesquisa 
Tabela 15 Número de ligações de abastecimento de água e percentual de atendimento por localidade

Tabela 16 Tarifa de água e esgoto em Reais para o consumo mínimo de $10 \mathrm{~m}^{3}$ das localidades do sistema Central II.

Tabela 17 Valores de DBO, DQO, sólidos totais, sólidos voláteis e coliformes fecais da Estação de Tratamento de Esgoto de Vila Cardoso

Tabela 18 Frequência de interrupções nos sistemas de água das localidades do sistema Central II, desde início de operação até o mês julho de 2002.

Tabela 19 Principais problemas relatados pela equipe de manutenção da Central II.

Tabela 20 Consumo médio de água per capita antes e depois da implantação do SAA e SES, segundo localidades do semiárido baiano, 2002

Tabela 21 Variação sazonal do consumo médio per capita em Vila Cardoso, 2001

Tabela 22 Custo da água antes e depois da implantação do SAA e SES, segundo localidades do semi-árido baiano, 2002........

Tabela 23 Desembolso médio mensal para consumo de água por residência antes da implantação do SAA e SES, segundo localidades do semi-árido baiano, 2002.

Tabela 24 Tempo médio diário gasto por moradores para obtenção da água antes da implantação do SAA e SES, segundo localidades do semi-árido baiano, 2002.

Tabela 25 Priorização do tempo disponivel pela população depois da implantação do SAA e SES, segundo atividade e localidades do semi-árido baiano, 2002.

Tabela 26 Priorização da morbidade referida relativa à falta de água antes da implantação do SAA e SES, segundo morbidade e localidades do semi-árido baiano, 2002 
Tabela 27 Alterações no valor do imóvel para compra e aluguel e número de residências nas localidades, segundo informação dos presidentes das associações de moradores das localidades estudadas, após a implantação dos sistemas de saneamento.

Tabela 28 Mudanças nas localidades após implantação de sistema de saneamento segundo informação dos presidentes das associações de moradores das localidades estudadas, após a implantação dos sistemas de saneamento

Tabela 29 Outras atividades comunitárias das associaçōes de moradores das localidades estudadas, após a implantação dos sistemas de saneamento.

Tabela 30 Destino do valor arrecadado pela conta de água após implantação do SAA e SES, segundo localidades do semiárido baiano, 2002

Tabela 31 Destino final dos esgotos domésticos citados pela população depois da implantação do SAA e SES, segundo localidades do semi-árido baiano, 2002.

Tabela 32 Populaçāo dos municípios Caém, Jaguarari e Pindobaçu, nos anos de 1991, 1996 e 2000 e respectivas taxas de crescimento

Tabela 33 Número de ligações, índice de adesão, total de casas, número de casas novas e taxa de crescimento de moradias, segundo localidades do semi-árido baiano, 118 2002

Tabela 34 Local de armazenagem de água antes do saneamento, segundo localidades do semi-árido baiano, 2002.

Tabela 35 Local de armazenagem de água depois do saneamento, segundo localidades do semi-árido baiano, 2002

Tabela 36 Origem da água de beber antes do saneamento, segundo localidades do semi-árido baiano, 2002 
Tabela 37 Origem da água de beber depois do saneamento, segundo localidades do semi-árido baiano, 2002................................

Tabela 38 Tipo de tratamento de água antes do saneamento, segundo localidades do semi-árido baiano, 2002.

Tabela 39 Tipo de tratamento de água depois do saneamento, segundo localidades do semi-árido baiano, 2002.

Tabela 40 Local de lavagem de alimentos antes do saneamento, segundo localidades do semi-árido baiano, 2002

Tabela 41 Local de lavagem de alimentos depois do saneamento, segundo localidades do semi-árido baiano, 2002.

Tabela 42 Local de lavagem de utensílios domésticos antes do saneamento, segundo localidades do semi-árido baiano, 2002.

Tabela 43 Local de lavagem de utensílios domésticos depois do saneamento, segundo localidades do semi-árido baiano, 2002.

Tabela 44 Local de lavagem das mãos antes do saneamento, segundo localidades do semi-árido baiano, 2002.

Tabela 45 Local de lavagem das mãos depois do saneamento, segundo localidades do semi-árido baiano, 2002.

Tabela 46 Local de lavagem de roupas antes do saneamento, segundo localidades do semi-árido baiano, 2002

Tabela 47 Local de lavagem de roupas depois do saneamento, segundo localidades do semi-árido baiano, 2002.

Tabela 48 Local de banho antes do saneamento, segundo localidades do semi-árido baiano, 2002

Tabela 49 Local de banho depois do saneamento, segundo localidades do semi-árido baiano, 2002

Tabela 50 Local de utilizado para defecar antes do saneamento, segundo localidades do semi-árido baiano, 2002.

Tabela 51 Local de utilizado para defecar depois do saneamento, segundo localidades do semi-árido baiano, 2002 
Tabela 52 Frequência de armazenamento da água antes do saneamento, segundo níveis de saneamento e localidades do semi-árido baiano, 2002.

Tabela 53 Frequência de armazenamento da água depois do saneamento, segundo níveis de saneamento e localidades

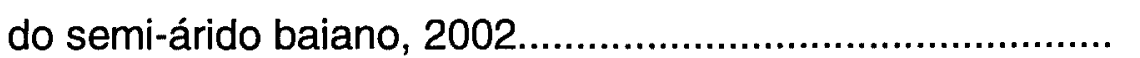

Tabela 54 Frequência de origem da água de beber antes do saneamento, segundo níveis de saneamento e localidades do semi-árido baiano, 2002................................................... 165

Tabela 55 Frequência de origem da água de beber depois do saneamento, segundo niveis de saneamento e localidades do semi-árido baiano, 2002

Tabela 56 Frequência de tipo de tratamento de água antes do saneamento, segundo níveis de saneamento e localidades do semi-árido baiano, 2002

Tabela 57 Frequência de tipo de tratamento de água depois do saneamento, segundo níveis de saneamento e localidades do semi-árido baiano, 2002.

Tabela 58 Frequência de local de lavagem de alimentos antes do saneamento, segundo níveis de saneamento e localidades do semi-árido baiano, 2002

Tabela 59 Frequência de local de lavagem de alimentos depois do saneamento, segundo níveis de saneamento e localidades do semi-árido baiano, 2002 ..

Tabela 60 Frequência de local de lavagem dos utensílios domésticos antes do saneamento, segundo níveis de saneamento $e$ localidades do semi-árido baiano, 2002...............................

Tabela 61 Frequência de local de lavagem dos utensílios domésticos depois do saneamento, segundo níveis de saneamento e localidades do semi-árido baiano, 2002 
Tabela 62 Frequência de local de lavagem das mãos antes do saneamento, segundo niveis de saneamento e localidades do semi-árido baiano, 2002

Tabela 63 Frequência de local de lavagem das mãos depois do saneamento, segundo níveis de saneamento e localidades do semi-árido baiano, 2002.

Tabela 64 Frequência de local de lavagem das roupas antes do saneamento, segundo niveis de saneamento e localidades do semi-árido baiano, 2002

Tabela 65 Frequência de local de lavagem das roupas depois do saneamento, segundo níveis de saneamento e localidades do semi-árido baiano, 2002

Tabela 66 Frequência de local de banho antes do saneamento, segundo níveis de saneamento e localidades do semi-árido baiano, 2002

Tabela 67 Frequência de local de banho depois do saneamento, segundo níveis de saneamento e localidades do semi-árido baiano, 2002.

Tabela 68 Frequência de local utilizado para defecar antes do saneamento, segundo níveis de saneamento e localidades do semi-árido baiano, 2002.

Tabela 69 Frequência de local utilizado para defecar depois do saneamento, segundo niveis de saneamento e localidades do semi -árido baiano, 2002

Tabela 70 Frequência de práticas sanitárias antes saneamento, segundo níveis de saneamento e localidades do semi-árido baiano, 2002

Tabela 71 Frequência de práticas sanitárias depois do saneamento segundo níveis de saneamento e localidades do semi-árido baiano, 2002 
Tabela 72 Número de crianças com menos de 2 anos e crianças com diarréia em Vila Cardoso (Caém). No período de abril de 1999 a setembro de 2000 ..

Tabela 73 Número de crianças com menos de 2 anos e crianças com diarréia nas demais localidades do município de Caém. No período de abril de 1999 a setembro de 2000.

Tabela 74 Número de crianças com menos de 2 anos e crianças com diarréia em Gameleira (Jaguarari). No período de maio de 2001 a outubro de 2002.

Tabela 75 Número de crianças com menos de 2 anos e crianças com diarréia em Jacunã (Jaguarari). No período de maio de 2001 a outubro de 2002

Tabela 76 Número de crianças com menos de 2 anos e crianças com diarréia nas demais localidades do município de Jaguarari. No período de maio de 2001 a outubro 2002.

Tabela 77 Número de crianças com menos de 2 anos e crianças com diarréia em Lajinha (Pindobaçu). No período de setembro de 1999 a dezembro de 2001

Tabela 78 Número de crianças com menos de 2 anos e crianças com diarréia nas demais localidades do município de Pindobaçu. No período de setembro de 1999 a dezembro de 2001

Tabela 79 Número de crianças com menos de 2 anos e crianças com diarréia nas localidades da pesquisa. No período de julho de 2001 a outubro de 2002

Tabela 80 Número de crianças com menos de 2 anos e crianças com diarréia nas demais localidades da pesquisa. No período

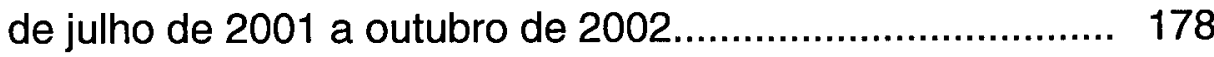

Tabela 81 T-Teste-Média antes e depois das variáveis da planilha....... 179

Tabela 82 T-Teste emparelhado........................................................ 180 


\section{LISTA DE SIGLAS}

ABNT

ACS

BIRD

$\mathrm{BNH}$

CAERN

CAGECE

CENTRAL 1

Associação Brasileira de Normas Técnicas

Agentes Comunitário de Saúde

Banco Interamericano da Reconstrução e Desenvolvimento

Banco Nacional de Habitação

Companhia da Água e Esgoto do Rio Grande do Norte

Companhia de Águas e Esgoto do Ceará

Central de Associações Comunitárias para Manutenção de Sistemas de Abastecimento de Água - Seabra

CENTRAL II Central de Associações Comunitárias para Manutenção de Sistemas de Abastecimento de Água - Jacobina

CERB Companhia de Engenharia Rural da Bahia

COPASA Companhia de Saneamento de Minas Gerais

DATASUS Sistema de Informações de Dados de Saúde do Ministério da Saúde

DNOS Departamento Nacional de Obras de Saneamento

EMBASA Empresa Baiana de Água e Saneamento

EPA Environmental Protection Agency

FGTS Fundo de Garantia de Tempo de Serviço

FMI Fundo Monetário Internacional

IBGE Instituto Brasileiro de Geografia e Estatística

IPEA Instituto de Pesquisa Econômica Aplicada

$\mathrm{KfW}$ Banco Kreditanstalt für Wiederaufbau

MDU Ministério do Desenvolvimento Urbano

MMA Ministério do Meio Ambiente, dos Recursos Hídricos e da Amazônia Legal

MS Ministério da Saúde

PACS Programa de Agente Comunitário de Saúde PLANASA Plano Nacional de Saneamento

PMSS Programa de Modernização do Setor Saneamento PROSANEAR Programa Para Populações De Baixa Renda 
SAA Sistema de Abastecimento de Água

SAAE Serviço Autônomo de Água e Esgoto

SANEPAR Companhia de Saneamento do Paraná

SES Sistema de Esgotamento Sanitário

SESP Serviço de Especial de Saúde Pública

SIAB Sistema de Informação de Atenção Básica

SNIS Sistema Nacional de Informação sobre Saneamento

UNT Unidades Nefelométricas de Turbidez 
SUMÁRIO

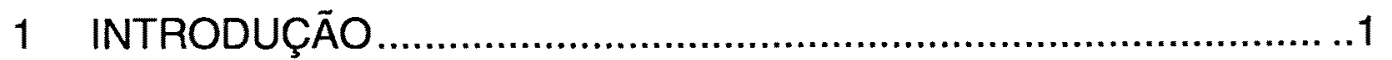

1.1 A Evolução do Saneamento Rural no Brasil..................................1

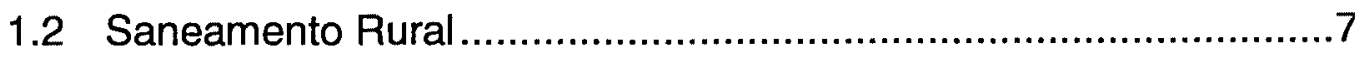

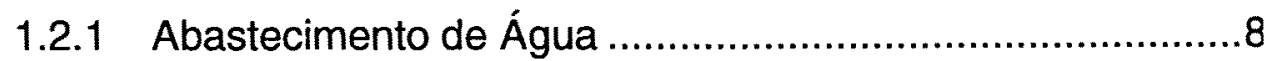

1.2.2 Esgotamento Sanitário ............................................... 14

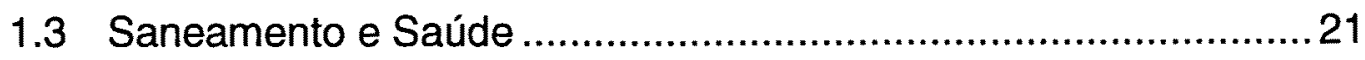

1.4 Saneamento Rural no Modelo Central ......................................27



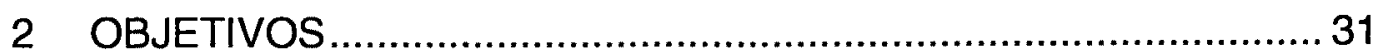

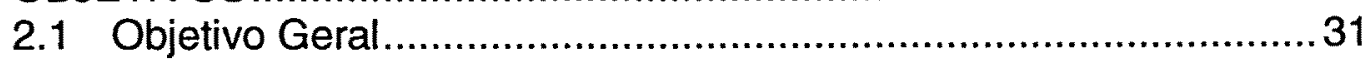

2.2 Objetivos Específicos.............................................................. 31

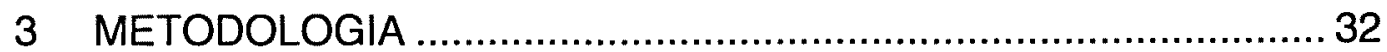

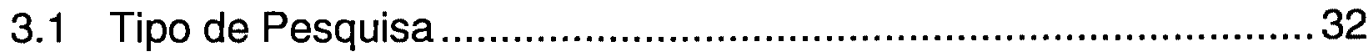

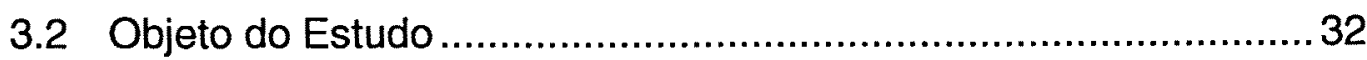

3.3 Procedimentos Metodológicos .................................................. 32

3.3.1 Levantamento Bibliográfico .............................................32

3.3.2 Levantamento Documental........................................... 32

3.3.3 Identificação e Seleção das Localidades do Estudo ...........33

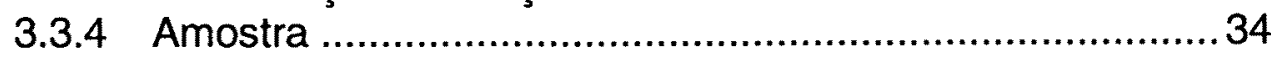

3.3.5 Instrumentos de Coleta de Dados ................................... 35

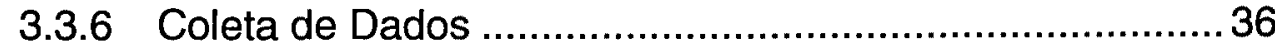

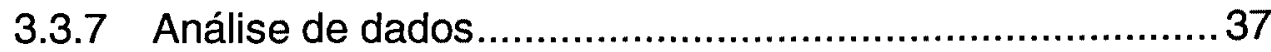

4 CARACTERIZAÇÃO DAS LOCALIDADES E DOS SISTEMAS DE SANEAMENTO

4.1 Caracterização das Localidades ................................................ 40

4.1.1 Vila Cardoso ................................................................. 44

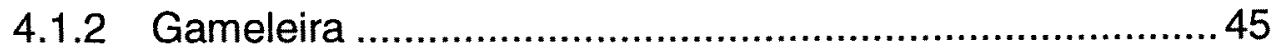

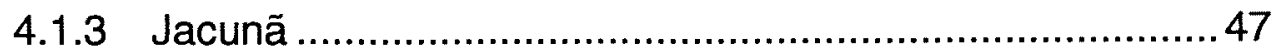

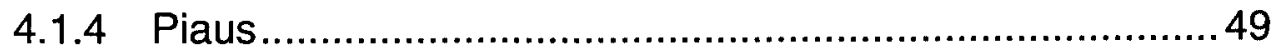

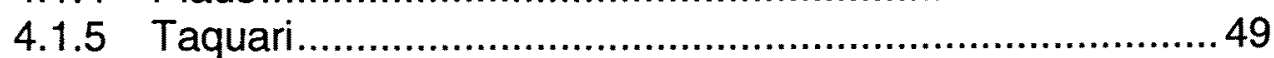

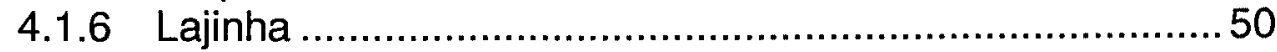

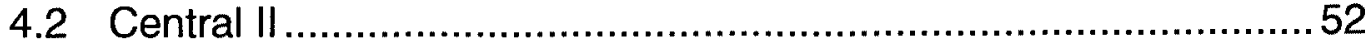


4.3 Sistemas de Abastecimento de Água e de Esgotamento

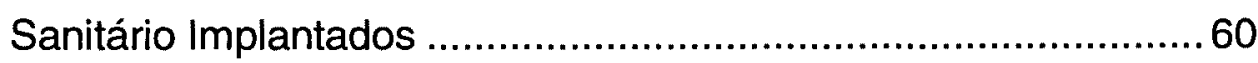

4.3.1 Sistema de Abastecimento de Água................................60

4.3.2 Sistema de Esgotamento Sanitário....................................64

4.3.3 Modelo de Operação dos Sistemas de Saneamento pela Central ............................................................................ 71

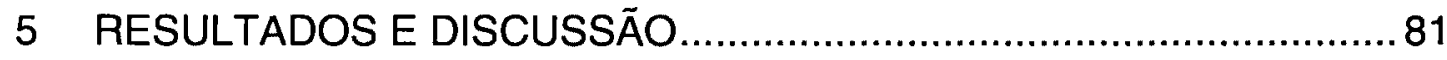

6 CONCLUSÕES E RECOMENDAÇÕES ......................................... 124

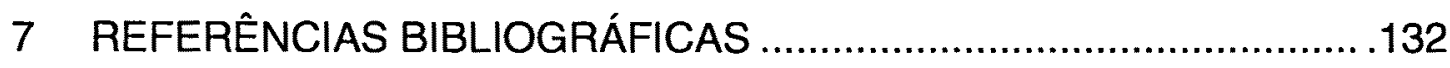

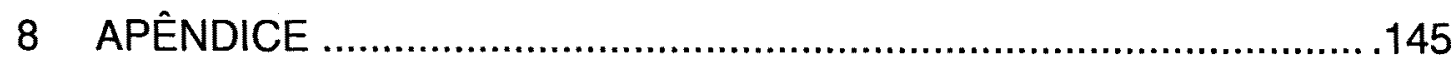

9 ANEXO 


\section{INTRODUÇÃO}

O saneamento rural e em pequenas comunidades apresenta peculiaridades que o diferenciam do saneamento implantado nas zonas urbanas. As comunidades envolvidas são pequenos aglomerados com poucos habitantes e, em muitas vezes, localizados de forma dispersa. Como agravante, destaca-se que em situações com pouca disponibilidade de recursos financeiros, baixa densidade habitacional e custo de captação da água relativamente alto (caso comum no semi - árido do nordeste brasileiro), a implantação de sistemas de saneamento não apresenta retorno financeiro como nos sistemas de saneamento de grandes centros urbanos. A implantação de um sistema de saneamento nos mesmos moldes utilizados nos grandes centros urbanos pode não se adequar à realidade local, resultando em baixa qualidade operacional e, por conseguinte, baixa adesão da população, não se atingindo assim aos objetivos de melhoria da saúde e da qualidade de vida desta população.

Face à recente implantação em localidades rurais do semi-árido baiano de um programa de saneamento com abastecimento de água residencial, esgotamento sanitário, implantação de melhorias sanitárias e estruturado para operar em parceria com a comunidade procurou-se estudar seus efeitos sobre a melhoria das condições de vida da população local.

\subsection{A Evolução do Saneamento Rural no Brasil}

A associação entre saúde e saneamento remete aos meados do século $X I X$, quando o trabalho clássico de John Snow (entre 1850 e 1854) relata a transmissão da cólera por fontes de água que abasteciam a cidade de Londres, antes mesmo de se haver identificado o vibrião da cólera (Cameron e Jones 1983 citado por ALMEIDA FILHO e ROUQUARYOL 1999). Nesse periodo começam na Europa as ações de saneamento básico e de saneamento ambiental com vista ao controle das epidemias de doenças 
veiculadas pela água. No Brasil, o processo de saneamento teve como marcos iniciais as ações, no Rio de Janeiro por Oswaldo Cruz, em 1903 e em São Paulo, por Emílio Ribas em 1904 (CHIORO e col. 1997). O modelo de intervenção baseava-se em campanhas de vacinação e na polícia sanitária. Nesse mesmo período, inicia-se o movimento da formação dos médicos-sanitaristas, quando já se buscava uma ação social que saneasse 0 meio rural para permitir a ocupação do interior do país e a construção de um povo saudável e racialmente forte (SALLES 1994).

Em 1918, Belisário Pena, médico higienista do Instituto Oswaldo Cruz publica o livro Saneamento do Brasil e funda a Liga Pró Saneamento (BRITTO e LIMA, 1991) congregando durante os anos de 1918 e 1919 médicos e intelectuais em torno do saneamento. Em seus dois anos de funcionamento, esta instituição promoveu palestras, conferências em associações e comunidades rurais, incentivando a prevenção da malária, doença de Chagas e ancilostomose. Efetuou também trabalhos junto ao Congresso Nacional no sentido da criação do Ministério da Saúde. Em 1917, o governo federal criou o Serviço de Profilaxia Rural, passando em 1919 a ser denominado Departamento Nacional de Saúde Pública.

A partir da década de 30 o saneamento passa a ser objeto, por parte do governo federal, de políticas que the conferem relevância no panorama nacional. Em 1933 o Governo Federal cria a Comissão de Saneamento da Baixada Fluminense, cuja repercussão positiva levou-a a ser transformada no Departamento Nacional de Obras de Saneamento - DNOS, com jurisdição em todo o território nacional. O DNOS tinha como foco principal a construção de grandes obras de engenharia destinadas ao controle de inundações e de drenagem de áreas alagadiças.

No caso específico do saneamento rural e de pequenas comunidades, um marco importante foi o acordo entre os governos do Brasil e dos Estados Unidos da América, em 1942, para a criação do Serviço de Especial de 
Saúde Pública - SESP, o que poderia permitir a ocupação de regiões importantes para a produção de borracha e minérios estratégicos neste periodo.

O Serviço Especial de Saúde Pública agregou ações da medicina sanitarista com as de engenharia para saneamento do meio, desenvolvendo e disseminando técnicas de construção e maneiras adequadas do uso de instalações sanitárias domiciliares e de sistemas simplificados de abastecimento de água; de destinação adequada de excretas e de resíduos sólidos, com o objetivo de evitar a proliferação dos vetores transmissores de doenças (MS 1987). Nesse sentido tem-se um marco da inserção da engenharia como instrumento de saúde pública, em especial no meio rural.

Após o final da II Guerra Mundial, o governo brasileiro decidiu pela manutençāo do SESP, vinculando-o ao Ministério da Saúde, e a partir deste período, o SESP implantou sistemas de abastecimento de água na zona rural e urbana, inclusive em diversas sedes municipais. Os sistemas eram repassados para os municípios com a criação do Serviço Autônomo de Água e Esgoto - SAAE, porém sob o suporte técnico e financeiro do SESP.

Nos demais municípios do país, o serviço de saneamento continuou a cargo das prefeituras locais, mas com a qualidade variando em função da disponibilidade de recursos e da política de saneamento local, ficando este setor com uma estrutura nitidamente dispersa e deficitária, não se criando uma política governamental de âmbito nacional para o mesmo.

Com o processo de urbanização crescente da década de 60 , o setor tornase incapaz de atender à demanda para ampliações e modernizações nos sistemas de abastecimento de água nas cidades. Em 1970 o Governo Federal cria o Plano Nacional de Saneamento - PLANASA. Com recursos provenientes do Banco Nacional de Habitação - BNH e do Fundo de Garantia de Tempo de Serviço - FGTS seriam criadas as empresas de 
saneamento estatais que teriam a concessão do serviço repassada do município. A meta inicial era de dotar de abastecimento de água em $80 \%$ da população urbana e de esgotamento sanitário em $50 \%$ da população urbana do país até o final da década de 80 (NAJAR 1991).

Em 1982, passados 12 anos da criação do PLANASA, verificou-se que apenas $78,8 \%$ da população urbana brasileira passou a ser atendida com sistema abastecimento de água e $31,9 \%$ por sistema de esgotamento sanitário. Além disso, o PLANASA havia concentrado suas açōes nas grandes cidades onde havia maior viabilidade econômica, não privilegiando as pequenas localidades e a zona rural. Os municípios que permaneceram com seus sistemas autônomos não tiveram acesso ao financiamento do $\mathrm{BNH}$, ainda que esses recursos fossem provenientes do FGTS, para o qual os trabalhadores desses municípios também contribuiam.

Em 1985 foi criado o Ministério do Desenvolvimento Urbano - MDU e o Programa para Populaçōes de Baixa Renda - PROSANEAR, redirecionando - PLANASA, que passa a contemplar os Serviços Autônomos de Água e Esgoto e introduz a drenagem urbana, os resíduos sólidos, na política do Saneamento.

Os baixos resultados obtidos e o consequente endividamento das companhias estatais de saneamento, associado ao processo de redemocratização dos anos 80 e a confecção da nova carta magna do país, fazem uma tentativa de universalização do saneamento e uma maior associação com os seus impactos na saúde e no meio ambiente. Conforme a Constituição Federal de 1988 (BRASIL 1988), compete à União instituir diretrizes para o desenvolvimento urbano, inclusive habitação, saneamento básico e transportes urbanos (Art. $21 \S \mathrm{XX}$ ) e ao sistema único de saúde, participar da formulação da política e da execução das ações de saneamento básico (Art. 200 § IV). 
O saneamento rural teve uma experiência diferenciada na década de 80 , realizada pela Companhia de Saneamento de Minas Gerais - COPASA, onde foi implantado um programa de Saneamento Rural no Vale do Jequitinhonha, denominado Programa de Melhoria Habitacional e Saneamento atendendo 34.600 habitantes em 34 localidades tendo como base a implantação de abastecimento de água, esgotamento sanitário com tecnologia de baixo custo, participação da comunidade no processo decisório e com a operação e manutenção dos sistemas a cargo das comunidades (ENNES 1990). Estas experiências subsidiaram a formulação do Programa Nacional de Saneamento Rural - PRORURAL, criado pelo Governo Federal em 1987. Uma segunda versão deste plano foi estabelecida em 1990, através da Secretaria Nacional de Saneamento e da Fundação Nacional de Saúde, cuja meta era implantar serviços de abastecimento de água e de esgotamento sanitário para 3.000 .000 de habitantes num prazo de 4 anos (OTTANI e col. 1989). O programa foi iniciado em 1987, com uma experiência piloto no estado de Minas Gerais sob a coordenação da COPASA (DIAS 1994).

Este programa não teve continuidade na década de 90 , bem como 0 PLANASA que, com a dispersão dos organismos que o fomentavam, teve $\circ$ seu declínio sem que as suas metas fossem alcançadas (REZENDE e HELER 2002). Em 1991, iniciou-se a tramitação de um projeto de Lei, que em 1993 foi denominado de PLC 199 (Projeto de Lei da Câmara 199) com o objetivo de regulamentar o saneamento no País. Após aprovação na Câmara Federal e no Senado em 1994, o Presidente Fernando Henrique Cardoso vetou-o na íntegra. Segundo MORAES e BORJA (2001), esse veto relaciona-se como 0 objetivo de privatização do setor em atenção às exigências do Banco Interamericano da Reconstrução e Desenvolvimento BIRD e do Fundo Monetário Internacional - FMI. Para isso, o governo apresenta o Programa de Modernização do Setor Saneamento - PMSS, que visava tanto preparar as empresas estatais concessionárias de água e de esgoto para venda, quanto remover da esfera municipal a titularidade dos 
serviços. Sob uma ótica contábil estrita, tem-se afirmado que as empresas do setor saneamento (estatais e municipais) são deficitárias. O ganho na saúde volta a ser colocado em segundo plano e a água passa a ser vista como uma mercadoria como outra qualquer. Nesse caso, o saneamento rural ficaria ainda mais prejudicado por conta da dificuldade técnica de se obter resultados operacionais positivos. O Projeto de Lei encaminhado pelo Poder Executivo ao Congresso Nacional em 2001, com o objetivo de viabilizar as mudanças pretendidas pelo PMSS, foi retirado no mesmo ano, permanecendo o país sem uma lei que ampare esse setor, conforme previsto na Constituição Federal.

No estado da Bahia, a situação é semelhante. Embora a Constituição Baiana, em seu Artigo 229 estabeleça a necessidade da formulação de uma Política Estadual de Saneamento, desde a sua promulgação em 1989, não houve a formulação dessa política, estando, até o presente momento, as definiçōes de prioridades e modos de investimento (MORAES e BORJA 2001) sob responsabilidades do poder executivo.

As ações de saneamento de água e de esgotamento sanitário no estado da Bahia são coordenadas pela Secretaria de Infra-Estrutura do Estado, à qual estão vinculadas a Empresa Baiana de Água e Saneamento - EMBASA, concessionária de serviços de abastecimento de água e de esgotamento sanitário, e a Companhia de Engenharia Rural da Bahia - CERB. Esta, destinada, primordialmente, à implantação de poços profundos, barragens e sistemas de abastecimento de água para a zona rural e para pequenos aglomerados urbanos do Estado. Mais recentemente a CERB também tem implantado sistemas de esgotamento sanitário em pequenas comunidades.

Os resultados da pesquisa do Sistema Nacional de Informação sobre Saneamento - SNIS, de 2000, realizada pelo Instituto de Pesquisa Econômica Aplicada - IPEA indicam que o serviço de abastecimento de água atende a $73,2 \%$ do total dos municípios do Brasil e a $89,6 \%$ da 
população urbana (IPEA 2001). Em termos de esgotamento sanitário os percentuais de atendimento são de $16,01 \%$ e $66,1 \%$, respectivamente.

\subsection{Saneamento Rural}

Neste item é apresentado um panorama geral das técnicas e procedimentos utilizados atualmente no campo do saneamento rural, sendo enfatizada a situação do semi-árido brasileiro. O saneamento rural abordado nesse trabalho compreende as ações de abastecimento de água e de esgotamento sanitário em habitações do meio disperso e de pequenas comunidades localizadas na zona rural dos municípios.

Usualmente o conceito de saneamento rural está associado ao conceito de sistemas simplificados de abastecimento de água e de esgotamento sanitário. O sistema simplificado de abastecimento de água é composto de uma captação em manancial superficial ou subterrâneo preferencialmente com potabilidade natural, seguido por transporte, reservação e distribuição através de chafariz. O esgotamento sanitário consiste da fossa seca ventilada.

A Associação Brasileira de Normas Técnicas - ABNT, através de suas normas técnicas para projeto, construção e operação de sistema de abastecimento de água e de esgotamento sanitário, estabelece poucas diferenças de critérios e parâmetros de dimensionamento e operacional entre os sistemas de saneamento (abastecimento de água e esgotamento sanitário) de grandes centros urbanos e pequenas comunidades do meio rural. Parâmetros como coeficiente de vazão máxima diária $(1,2)$, coeficiente de vazão máxima horária $(1,5)$, relação esgoto gerado/ consumo de água $(0,8)$ e coeficiente de infiltração na rede coletora $(0,0002 \mathrm{~L} / \mathrm{s}$.m a $0,0005 \mathrm{~L} / \mathrm{s} . \mathrm{m}$ ) são os mesmos independentemente do porte da comunidade atendida. A diferenciação é feita no consumo per capita, cujo valor é estabelecido em função do tamanho da população da localidade. 


\subsubsection{Abastecimento de Água}

As etapas comumente utilizadas em um sistema de abastecimento de água são apresentadas a seguir, podendo haver, naturalmente, a eliminação de uma ou mais etapa em função das características de cada sistema.

\section{Captação}

No caso do Estado da Bahia, em especial na área do semi-árido, a pouca disponibilidade de água superficial e a intermitência de vazão da maioria dos rios dificultam a captação tanto a fio d'água quanto por barragem de nivel. As soluções mais comuns para captação de água têm sido o uso do aquífero subterrâneo ou de rios através de barragem de regularização. No entanto, a barragem apresenta uma maior vulnerabilidade a contaminações por atividades antrópicas devido à própria escassez da água na região que faz com que a população utilize este manancial para outros fins como banho, lavagem de roupa e dessedentação de animais.

A captação de água de chuva é uma prática disseminada no semi-árido brasileiro, onde a isoieta média anual é de $500 \mathrm{~mm}$ e variando entre valores inferiores a $300 \mathrm{~mm}$ e $500 \mathrm{~mm}$, sendo que $60 \%$ desse total acontece em apenas 3 meses do ano (REBOUÇAS e col. 1999). A pouca concentração de sais e de outros compostos na água de chuva the confere um sabor mais agradável para ingestão. Quando possível essa é a opção da população, para uso de beber e de cozimento, ao passo que as águas de poços e de cacimbas são utilizadas para lavagem geral.

Para utilização das águas de chuva, o padrão usual é um reservatório com volume entre $25 \mathrm{e} 80 \mathrm{~m}^{3}$ que recebe as águas do telhado da casa. Conforme (AZEVEDO NETTO 1991), uma casa com um telhado de $56 \mathrm{~m}^{2}$ associado a um reservatório de $42 \mathrm{~m}^{3}$ permite a uma familia de 5 pessoas a quantidade 
de água para o consumo por um período de 3 meses, o que corresponde ao período de estiagem usual na região. Uma publicação da Associação Brasileira de Educação Agrícola (MMA 1998) apresenta uma tecnologia de construção de reservatórios pela própria população em que se utiliza a argamassa armada. São tanques com volume em torno de $36 \mathrm{~m}^{3}$, estanques e protegidos de contaminações e que, embora menores do que os tanques anteriormente propostos atendem às necessidades de uma família.

A população costuma utilizar, para desinfecção da água, compostos de cloro (como a água sanitária) ou pedras de enxofre. $O$ uso dessas pedras de enxofre para a desinfecção de água é muito comum nas áreas rurais e também nas cidades do interior do estado, muito provavelmente pela propriedade do enxofre de impedir a proliferação de bactérias, porém, a literatura técnica de saneamento não faz referência a esse método não se conhecendo o real efeito desinfetante ou mesmo se há efeito residual. Todavia, uma pesquisa realizada por meio de entrevistas a uma amostra da população da cidade de Feira de Santana (DIAS e ARAÚJO 1997), apresenta uma grande confiança daquela população nas pedras de enxofre para desinfecção da água e também para terapia de diversos problemas de saúde.

\section{Qualidade da Água}

A qualidade da água fornecida à população por abastecimento público tem sido regulamentada por intermédios de Portarias do Ministério da Saúde, que estabelecem os padrões físicos, químicos e bacteriológicos que a água deve apresentar para a garantia da sua potabilidade. A atual portaria 1.469 de 29 de Dezembro de 2000 (MS 2001), substitui a Portaria 36/GM de 19 de Janeiro de 1990, também expedida pelo Ministério da Saúde. Dentre as diversas mudanças da nova portaria, destaca-se a obrigatoriedade de desinfecção da água a ser distribuída, independentemente da mesma ter potabilidade natural. A frequência de amostragem da água distribuída é 
definida pelo tipo de manancial utilizado e pelo número de pessoas atendidas pelo sistema.

O grupo de sistemas de menor porte refere-se aos que atendem a uma população com menos de 50.000 habitantes, incluindo assim os pequenos sistemas de abastecimento da zona rural cuja realidade sócio econômica é distinta das cidades com população na faixa de 10.000 a 50.000 habitantes. Conforme a nova portaria, pequenas comunidades que utilizam manancial subterrâneo devem efetuar a coleta de amostras na saída do tratamento para análise de cloro residual com uma frequência diária para manancial subterrâneo e a cada duas horas para os sistemas que utiliza manancial superficial.

Considerando as grandes distâncias dessas localidades até os centros urbanos, onde estão localizados os laboratórios de análises físico-químicas e bacteriológicas, bem como as condições precárias de acesso, o atendimento desse item apresenta dificuldades operacionais e logísticas. Estas se traduzem em um custo de monitoramento mais alto do que os das cidades, com o agravante de que a receita tarifária é menor.

\section{Tratamento}

Para as águas superficiais nas quais os teores de cor e turbidez estão acima do limite de potabilidade, deve-se utilizar as estações de tratamento convencional. Porém as Estações Compactas de Tratamento de Água contendo as unidades de mistura rápida, floculação, decantação e filtração além da casa de química, apresentam vantagens relativas à implantação e também podem ser substituídas por outras de maior porte, caso necessário (BARROS e col. 1995). Embora a operação das Estações Compactas de Tratamento de Água seja simples e, portanto, factível de sucesso em pequenas localidades, o seu funcionamento requer $\mathrm{o}$ uso de produtos 
químicos, o que eleva o custo operacional e apresenta dificuldades relativas ao transporte destes produtos.

Uma alternativa de tratamento consiste no Filtro Lento, que tem sido usado para o tratamento de águas de abastecimento na Europa, desde o século $X I X$ até o presente momento, a exemplo de áreas da cidade de Londres, (BARROS e col. 1995). A operação de estações de tratamento de água com Filtro Lento não requer o uso de produtos químicos, porém a sua construção necessita de uma maior área do que à requerida pelo sistema de tratamento convencional, e a água bruta deve também estar enquadrada no Tipo $B$ (ABNT 1992), com turbidez inferior ou igual a 40 Unidades Nefelométricas de Turbidez - UNT.

As águas de poços profundos geralmente possuem baixo teor de cor, turbidez e não apresentam contaminação bacteriológica. Quando os demais compostos encontram-se com teores abaixo dos limites superiores de potabilidade faz-se apenas a desinfecção através da cloração. Os tratamentos mais frequentes referem-se à redução do teor de Ferro e Manganês através de Aerador (CETESB 1977) e da redução do teor de salinidade através de Dessalinizador, utilizando o princípio da osmose reversa (MS 1999).

\section{Sistemas de Recalque}

O bombeamento manual é uma solução indicada para pequenos aglomerados de casas dispersa no meio rural, com poucos recursos econômicos e onde o manancial subterrâneo encontra-se à pouca profundidade. Porém, as características hidrogeológicas do semi-árido brasileiro, com água subterrânea a grandes profundidades (superiores a 50 metros), limitam a sua utilização, sendo a solução mais usual o sistema de recalque com bombas movidas a motores elétricos ou a óleo diesel. Os sistemas de recalque com motores elétricos requerem menor custo de 
manutenção e a operação pode ser automatizada. Sua desvantagem ocorre quando o manancial situa-se afastado da localidade, o que demanda custo adicional da implantação da linha de transmissão. Sistemas com motores elétricos de fonte de energia solar são ainda incipientes no Brasil e, por enquanto, suas potências não são ainda suficientes para recalques de grandes profundidades.

\section{Reservação}

Os reservatórios de distribuição de água, conforme a Norma Brasileira (ABNT 1994a) devem ter um volume correspondente a $1 / 3$ do volume da água consumida por dia pela população abastecida. Atualmente, além do concreto armado, tem-se utilizado materiais a base de resinas químicas como a fibra de vidro pré-moldada, possibilitando a implantação de reservatórios mais leves e em locais de difícil acesso para a construção em concreto armado. Para a reservação domiciliar são também utilizadas unidades pré-fabricadas de fibra de vidro e de cimento amianto.

\section{Chafariz ao longo da adutora}

Nas duas últimas décadas em algumas adutoras de água construidas pela CERB, foram previstos pontos de saída para abastecimento ao longo da adutora para fornecimento de água aos moradores da zona rural (meio disperso). Alguns desses pontos possibilita a conexão da tubulação de Caminhão Pipa, conforme visto na Figura 1. 


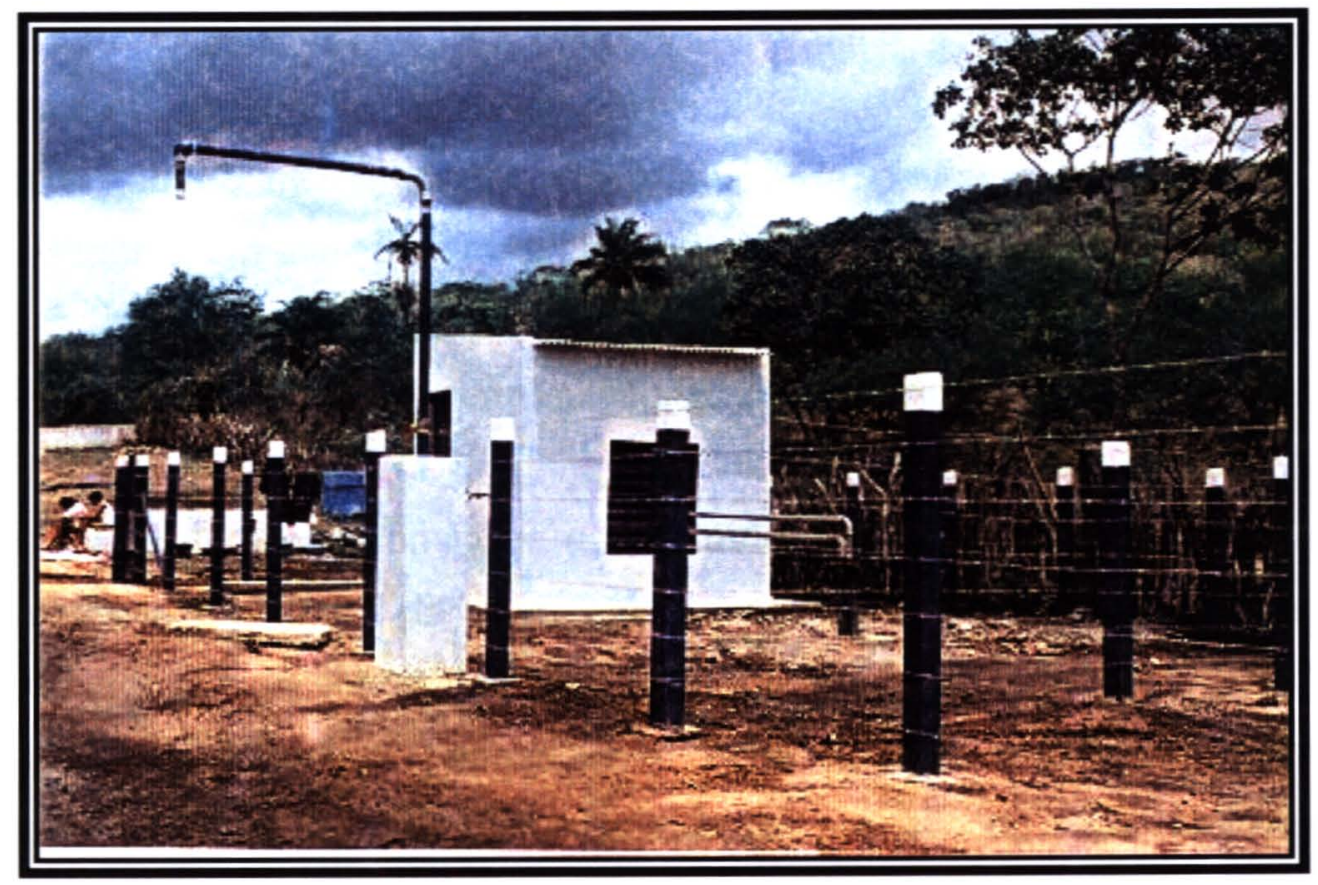

Figura 1 Ponto de abastecimento para população do meio disperso e para caminhão pipa.

Considerando que o saneamento deve ser aplicado de forma progressiva, essa solução pode ser vista como um avanço e como uma melhoria para as condições de abastecimento de água nesses locais. O ponto de água pode estar distante cerca de 2 quilômetros da residência, mas ainda assim tratase de uma condição melhor do que a existente anteriormente. O problema mais frequente tem sido a manutenção e reparos devido à distância e ao isolamento dessas unidades em relação às habitações.

\section{Distribuição}

O chafariz como ponto de distribuição de água potável ainda é uma solução adotada, principalmente, quando o aglomerado possui uma densidade habitacional baixa, inviabilizando a instalação de rede de distribuição domiciliar. O chafariz induz um menor consumo de água por habitante, o que pode ser indicado em situações em que há pouca disponibilidade de água para distribuição, mas inconveniente por oferecer maior probabilidade de contaminação da água em função dos vasilhames que são utilizados em 
transporte e reservação. Na maioria dos casos a água distribuída por chafariz não é tarifada, refletindo na dificuldade de captação de verba para manutenção do sistema e no desperdício da pouca água captada. Em localidades do interior da Bahia após a instalação de rede hidrometrada foi verificada uma redução do consumo de água per capita de 220L/hab.dia para 100L/hab.dia devido à diminuição do desperdício (LOPES e col. 1995).

A rede de distribuição domiciliar, ao contrário do chafariz, permite a tarifação e garante a qualidade da água até as residências, porém, a reservação domiciliar continua sendo um ponto vulnerável à manutenção da qualidade da água. A reservação domiciliar é necessária basicamente devido à intermitência do abastecimento e pela baixa pressão da rede que impede que a água alcance o reservatório superior da residência. Ambos os casos não deveriam acontecer, pois estariam em desacordo com a Norma Brasileira (ABNT 1994b) que estabelece a pressão mínima na rede de distribuição de 8 m.c.a, e também com o Código de Defesa do Consumidor (Brasil 1990) e com a Portaria 1.469 de 2000 do Ministério da Saúde (MS 2001).

\subsubsection{Esgotamento Sanitário}

Para fins desta análise, o esgotamento sanitário será aqui abordado em suas vertentes individual e coletiva.

\subsubsection{Sistemas Individuais}

Os sistemas individuais mais utilizados são a fossa seca ventilada e a fossa séptica seguida de pós-tratamento com disposição no solo. 


\section{Fossa Seca Ventilada}

A fossa seca ventilada é considerada uma solução adequada para locais onde não há disponibilidade de água para a descarga hídrica dos dejetos (fezes e urina) (MS 1999). Em áreas rurais sem rede de distribuição de água, a solução da fossa seca é indicada, pois com este recurso é possível quebrar o ciclo de reprodução de vida de muitos microrganismos patogênicos. Ainda assim, face ao pouco conhecimento dos aspectos sanitários por parte da população rural, observa-se a ausência desses dispositivos em muitas das residências de pequenos povoados.

\section{Fossa Séptica e Pós Tratamento}

A Fossa Séptica é recomendada como a solução de tratamento para sistemas individuais e de pequenos grupos de domicilios em áreas onde não há sistemas coletivos de esgotamento sanitário. $\mathrm{A}$ atual Norma de Projeto de Fossas Sépticas (ABNT 1993), inclui parâmetros de temperatura ambiente e frequência de remoção do lodo como critério para o dimensionamento deste reator. As alternativas de pós-tratamento do efluente do Tanque Séptico passam a ser descritas na nova Norma (ABNT 1997) em que, além dos já anteriormente previstos (Filtro Anaeróbio, Sumidouro, Valas de Infiltração e Valas de Filtração), são apresentados novos tipos de alternativas como Filtro Anaeróbio Submerso, Lodos Ativados por Batelada e Lagoas com Plantas Aquáticas.

\subsubsection{Sistemas Coletivos}

No caso de agrupamento de residências, a opção por rede coletora seguida de tratamento coletivo deve ser priorizada, tendo em vista o custo de implantação e de operação por habitante ser na maioria das vezes inferior ao custo para a solução individualizada. Além dessa vantagem econômica, há um ganho coletivo. Do ponto de vista da coletividade, o tratamento 
individual (fossa séptica seguida de infiltração no solo) é incorporado ao patrimônio privado, ao contrário da rede coletora que pertence à comunidade possibilitando a conexão de futuras casas ao sistema.

\section{Rede Coletora.}

Tanto para grandes cidades quanto para pequenos povoados a proposta de rede coletora vem sofrendo uma modificação conceitual, com base nas experiências do modelo de rede coletora condominial iniciadas na década de 80, em pequenas cidades do Rio Grande do Norte, pela Companhia de Água e Esgoto do Rio Grande do Norte - CAERN (ANDRADE NETO 1985).

O sistema condominial apresenta vantagens no aspecto técnico econômico na medida em que o custo de implantação do sistema condominial (ramal condominial/rede básica) estar entre $1 / 3$ e $1 / 2$ do sistema convencional (AZEVEDO NETTO 1992). Além dessa vantagem, tem-se de uma forma inédita, a incorporação de fatores sociais, como por exemplo, a educação sanitária e a participação da comunidade no processo decisório na construção e na manutenção da rede coletora.

A rede coletora, ao passar no fundo dos lotes, é mais facilmente conectada às instalações hidráulicas residenciais, pois, na maioria das vezes, a cozinha e o sanitário situam-se no fundo da casa e a uma elevação inferior à da rua. Além desse fato, tem-se que, nas localidades da zona rural, é comum a construção da casa ocupar toda a largura do lote, não havendo espaço para a implantação de uma tubulação entre o fundo da casa e a rua.

A participação comunitária é a base do sistema condominial. Sua finalidade é promover a participação no processo de implantação do sistema e na sua futura operação, e através dessa participação se concretizam as propostas pelo novo modelo, as idéias e soluções que levam ao atendimento pleno. 
A reunião condominial é o momento de participação, negociação, decisão e promoção da organização comunitária. Nessa oportunidade é realizado o trabalho de educação sanitária, de conteúdo adaptado às características sócio-culturais da população local, e que deve tratar, pelo menos, do uso adequado e conservação do sistema de esgotos sanitários. É também escolhido um síndico para cada quadra, responsável pela limpeza e manutenção básica, além da mediação de eventuais conflitos entres os moradores (MELO 1985).

\section{Estações Elevatórias}

Face ao pequeno porte das instalações usualmente são utilizadas bombas submersas de eixo vertical, ficando a bomba instalada no próprio poço de sucção. O emprego de estação elevatória de esgoto sanitário em contraposição à adoção de sistemas de esgotamento por bacia deve ser cuidadosamente analisado, pois sistemas de elevação são pontos vulneráveis a falhas e aumentam o custo de operação, manutenção e reparos. Sempre que possivel deve-se procurar adotar soluçōes que dispensem ou reduzam 0 uso de estações de bombeamento em esgotamento sanitário na zona rural.

\section{Tratamento}

O tratamento dos esgotos deve seguir a linha da simplicidade de construção e de operação. Dentre os diversos tipos de sistemas existentes os mais empregados têm sido o Tanque Séptico Coletivo, o Tanque Imhoff e o Reator Anaeróbio de Fluxo Ascendente.

O Tanque Séptico Coletivo, previsto atualmente pela Norma Brasileira (ABNT 1997), possui as mesmas características do Tanque Séptico Unidomicilar, diferenciando apenas nos detalhes construtivos e no número de câmaras. 
O Tanque Imhoff diferencia-se basicamente do Tanque Séptico pela presença, no seu interior, de anteparos destinados a reduzir as interferências no movimento descendente da sedimentação dos sólidos e no movimento ascendente dos gases produzidos pela digestão, assim como pela presença de uma câmara de depósito do material (JORDÃO e PESSOA 1995). Trata-se de um tipo de sistema disseminado no meio rural e em conjuntos habitacionais localizados em zona urbana ou periférica, onde não há rede coletora de esgoto sanitário. Sua operação é simples, não requerendo mão-de-obra especializada nem procedimentos frequentes de manutenção. Requer, todavia, a remoção do lodo digerido num período de 6 meses a 1 ano. A eficiência de remoção da matéria orgânica está no intervalo de 40 a $60 \%$.

Tanto o Tanque Séptico quanto o Tanque Imhoff caracterizam-se pela sua simplicidade operacional, sem partes mecânicas, não requerendo a presença de operador hábil e podendo funcionar durante muitos meses sem exigir cuidados especiais, sendo indicado para diversos tipos de comunidades (AZEVEDO NETTO 1985).

O Reator Anaeróbio de Fluxo Ascendente foi desenvolvido inicialmente com - objetivo básico de aproveitamento do gás metano resultante da biodegradação de águas residuárias de agroindústrias. Atualmente tem sido utilizado com sucesso no tratamento de esgoto doméstico em regiões de clima quente (ORRICO 1992). A eficiência do reator na remoção da matéria orgânica de esgotos domésticos situa-se entre 45 e 85\% (CHERNICHARO 1997) e a na de patógenos em torno de $90 \%$. Sua operação é simples e a alta eficiência de remoção da matéria orgânica em relação aos outros sistemas anaeróbios resulta numa maior conversão da fase líquida para a fase sólida o que faz requerer descargas frequentes do mesmo (entre $15 \mathrm{e}$ 30 dias), podendo vir a ser uma dificuldade para sua utilização em localidades com baixa estrutura econômica e pouca mão-de-obra especializada. 
A entrada do afluente no interior do reator dá-se pela parte inferior, fazendo com que haja um maior contato entre a matéria orgânica do efluente e o lodo de bactéria. Dispositivos internos encaminham separadamente o gás gerado e o líquido para fora do reator. Um compartimento de sedimentação localizado na saída do efluente retém o lodo (bactérias anaeróbias) para retornar ao sistema.

\section{Lagoas de Estabilização}

As lagoas de estabilização são as lagoas anaeróbias e as lagoas facultativas. Estas últimas utilizadas isoladamente ou em conjunto com um tratamento anaeróbio. A simplicidade operacional que apresentam e a adequação às condiçōes climáticas da região são fatores que as indicam como uma opção de tratamento para a zona rural. As lagoas anaeróbias podem trabalhar a uma taxa de $2.000 \mathrm{Kg} \mathrm{DBO} / \mathrm{ha}$.dia e as facultativas a uma taxa de $400 \mathrm{Kg}$ DBO/ha.dia (SPERLING 1996). Suas limitações referem-se à disponibilidade de área com relevo e tipo de solo que possibilitem uma construção econômica.

\section{"Wetland"}

"Wetland" trata-se de um sistema já difundido na Europa e na América do Norte, tendo como princípio a simulação de uma área úmida (área embrejada) onde os microorganismos juntamente com as raízes da vegetação promovem a remoção da matéria orgânica, nitrogênio, fósforo $e$ patógenos (HARBEL 1998). A eficiência de remoção da DBO é na faixa de $90 \%$, a de nitrogênio de 30\% e de fósforo 15\% (EPA 1992). A NBR 13.969 da ABNT apresenta um campo de tratamento onde ocorre a degradação da matéria orgânica por processos bioquímicos, a infiltração no solo e a evapotranspiração. 


\section{Reúso}

O reúso de efluentes através do seu lançamento no solo contribui favoravelmente para a conservação dos cursos d'água superficiais, na medida em que essa prática melhora a qualidade e reduz o volume de água lançado no corpo d'água. A retenção de elementos nocivos dos esgotos no solo permite que os mesmos sejam confinados e controlados mais adequadamente, principalmente na região do semi-árido face à escassez de água. O reúso de efluente tratado é previsto pela Norma Brasileira (ABNT 1997).

O termo reúso no sentido técnico refere-se a um reúso controlado, que vincula qualidade da água a finalidades que não venham a causar conseqüências maléficas nem ao meio ambiente, tampouco à saúde humana. A prática agrícola tem sido a mais recomendada para o reúso da água de esgotamento sanitário. No Brasil, dentro do aspecto formal e controlado, essa prática é ainda incipiente. Em São Paulo, a Companhia de Saneamento Básico do Estado de São Paulo-SABESP vem operando desde 1983 uma estação de tratamento de esgoto com aplicação direta no solo (PAGANINI 1997). Recentemente a Companhia Riograndense de Saneamento - CORSAN negociou com o dono de uma propriedade a compra de uma área para implantação de uma estação de tratamento de esgoto de uma cidade e o direito de uso do efluente para fins de irrigação de cultura de arroz (ANONYMUS 2001).

No caso específico do semi-árido baiano a premência do reúso da água se da pela própria dificuldade de obtenção de água tanto para uso doméstico quanto para atividades econômicas como a agropecuária. 


\subsection{Saneamento e Saúde}

Intervenções em infra-estrutura de saneamento numa comunidade apresentam via de regra efeito multiplicador e sistêmico. De modo que, a longo prazo, os efeitos sobre a saúde podem ser superiores aos das intervenções médicas (Briscoe 1987 citado por HELLER e col. 1997b, p11). Roberts (1997) verificou que a redução de doenças de veiculação hídrica tem sido observada, quase sempre, após a implantação de sistemas de abastecimento de água, mesmo quando o fornecimento é intermitente e a qualidade da água não atende aos padrões de potabilidade estabelecidos. No entanto, ainda que a implantação de infra-estrutura de saneamento básico seja uma condição básica para a redução da incidência de doenças de veiculação hídrica em determinada população, a saúde não é geralmente o objetivo mais importante do saneamento, segundo o entendimento dos usuários (CAIRNCROSS 1993), o objetivo de mais importante do saneamento é o conforto da disponibilidade de água na torneira de sua casa e a um custo inferior ao do que se pagava a vendedores da água.

Usualmente o impacto das intervençōes de saneamento tem sido avaliado através das variações de incidência e prevalência de doenças de veiculação hídrica, sendo a diarréia infantil o agravo à saúde mais freqüentemente enfocado, (HELLER 1997a). Helmintoses, hepatite e doenças de pele também têm sido consideradas. As medidas antropométricas também são consideradas como fatores para avaliação do impacto, uma vez que estão quase sempre relacionadas com o estado nutricional infantil (MORAES 1997). De modo geral os resultados apresentam correlação positiva entre intervenções em infra-estrutura de saneamento e redução da incidência dessas doenças e, consequentemente, diminuição da mortalidade infantil. Casos clássicos, como a redução de incidência de febre tifóide na cidade de São Paulo e em cidades dos Estados Unidos (RODRIGUES 1985), são frequentemente citados na literatura de Saúde Pública e de Saneamento. 
Ainda assim, tem sido observado que, embora necessárias, as intervenções em abastecimento de água e em esgotamento sanitário nem sempre são suficientes para promoção de melhoria na saúde da população. Briscoe (1984) citado por HELLER (1997a, p. 10), verificou que, quando a incidência de uma determinada enfermidade possui diferentes vias de infecção, a eliminação de apenas uma da vias pode não reduzir a incidência na mesma proporção.

CAIRNCROSS (1997) mostra que a redução das doenças de veiculação hídrica a partir de intervenções em infra-estrutura de saneamento pode sofrer interferência negativa de outros fatores, tais como: ausência de instalações sanitárias básicas (vaso e lavatório sanitário dentro do domicílio), inexistência de esgotamento sanitário com tratamento e destino final adequados e falta de hábitos de higiene adequados na população.

Fatores externos e circunstanciais, como ausência de fornecimento de água potável e a presença de esgoto a céu aberto, podem ser controlados através da construção de estruturas de saneamento. No entanto, outros fatores internos, a exemplo de infra-estrutura sanitária da residência e de hábitos de higiene do grupo familiar e da comunidade, devem também ser objeto de controle.

Num estudo realizado na Etiópia (GETANEH e col. 1997), foi verificado que apesar de vários fatores mostrarem associação significativa com a morbidade por diarréia infantil, a idade da criança, sua situação de imunização, a etnia dos pais, a renda familiar e a disponibilidade de latrina em casa, constituíram-se nas mais significativas. No caso de intervenção com obras de saneamento, a disponibilização de latrina seria então um fator preponderante na redução de morbidade infantil diarréica.

Para que a frequência do uso de latrinas aumente, é necessário que a população não só tenha acesso ao equipamento, mas também se 
conscientize dos seus efeitos sobre a qualidade de vida. Em uma pesquisa sobre usos de latrinas na Malásia (KIYU e col. 1993) verificou-se que a maior razão apontada pelos entrevistados, para justificar o não uso da latrina, era a falta d'água e o fato de estar no campo quando necessitava da mesma, e, dentre os motivos de utilizar a latrina, apontados pelas mulheres, apenas $2,4 \%$ das entrevistadas indicaram a prevenção de doenças, ao passo que $55,3 \%$ apontaram a comodidade de manter a área limpa.

A ausência de latrina foi identificada também em um estudo realizado no Egito (MAHMUD e col. 1995), como o fator de maior risco relativo à infecção por Giárdia em crianças, dentre outros componentes referentes a aspectos sociais, educacionais e, até, à qualidade da água.

A implantação de instalações hidráulicas sanitárias necessita ser acompanhada de um programa de educação sanitária para que se possa garantir o uso correto dos equipamentos.

No Paquistão, em um programa de melhoria de infra-estrutura física e social (NORTHROP-CLEWES e col. 1998), foram implantadas bombas manuais nos poços para abastecimento de água e sanitários nas casas, além de campanhas de vacinação e de planejamento familiar. Esses dois últimos tópicos apresentaram resultados positivos, porém foi verificado que após 10 anos do programa, cerca de $50 \%$ da população continuavam a utilizar água de poços abertos e a defecar em campo aberto, além de não armazenar a água com segurança nem de manter práticas doméstica higiênicas. $O$ estudo atribui a essa baixa adesão ao programa à inexistência de um plano de educação sanitária e, como consequência disso, $24 \%$ das consultas médicas, em crianças menores de 5 anos, se dão por diarréia infantil aguda.

A falta de fornecimento contínuo de água resulta em perda da qualidade da água fornecida à população. As manobras de registro realizadas nos sistemas para alternar o fornecimento de água numa dada área deixam a 
tubulação sem pressão interna e em muitas vezes com pressão negativa, ficando a rede vulnerável à contaminação. Um estudo em Nova Iguaçu (D'AGUILA e col. 2000) mostrou que $61 \%$ das amostras de água coletadas na rede de distribuição apresentavam contaminação por coliformes fecais. Em Salvador, um valor de $39 \%$ de amostras contaminadas foi encontrado na rede de distribuição da cidade de Salvador, nos anos de 1988 (CARVALHO e col. 1990) e de 33\% no período de 1989 a 1998 em uma área da periferia de Salvador (MORAES e col. 1999).

Além desse problema, a intermitência do fornecimento de água induz a população a construir reservatórios domiciliares que, por sua vez, são também ponto vulnerável de contaminação da água. A vulnerabilidade dos reservatórios domiciliares decorre da sedimentação de material em seu fundo, da falta de limpeza periódica e da simples ausência da tampa. Em pesquisa realizada em uma cidade do Pará (LIMA e BERNADES 2001), verificou-se que a contaminação por coliformes fecais, nos reservatórios domiciliares pesquisados, variou entre 60 a $80 \%$ dependendo do setor de abastecimento, embora a água fornecida pelo sistema público de abastecimento se apresentasse dentro dos padrões de potabilidade.

Estudo desenvolvido durante 2 anos em 31 cidades cubanas com população entre 500 a 900 habitantes (total de 35.000 habitantes) associou, mediante correlação inversa, a desinfecção da água de abastecimento público e a freqüência de consultas ao serviço de saúde nacional relativas a eventos de diarréia infantil aguda (PRIETO e col. 2000).

Um estudo de coorte realizado em povoados indígena da Bolívia (QUICK e col. 1999), verificou que a incidência de diarréia infantil foi $44 \%$ menor no grupo em que se fazia desinfecção da água no local de consumo, armazenamento seguro e educação da comunidade neste sentido. 
A desinfecção da água de distribuição em zonas rurais é um desafio, pois a situação de longa distância e de acesso, muitas vezes difícil, pode trazer empecilhos ou inviabilizar esse procedimento.

Em uma comunidade Masai no Quênia (CONROY e col. 1999), verificou-se que o grupo populacional que utilizava a mesma água do grupo controle com turbidez acima de 200 NTU e $10^{3}$ de coliformes fecais, porém, armazenada em frascos transparentes e expostos ao sol, apresentou uma prevalência de diarréia infantil de $48,8 \%$, diferentemente do grupo controle que apresentou o valor de $58,1 \%$ (odds ratio de 0,65 ). Estes dados comprovam que, se a redução do risco não é significativa, o custo também não o é.

O custo da água pode influenciar nos resultados de melhoria da saúde da população, uma vez que, sendo elevados, podem induzir a população a consumir água de outras fontes, não confiáveis, a restringir o consumo da água fornecida ou a reduzir gastos com alimentação para garantir o pagamento da conta de água.

Muitos dos casos de não adesão da população ao sistema de saneamento deve-se a diversos fatores, como a não adequação da sua concepção à realidade sócioeconômica da região, o custo e sabor da água e a intermitência do seu fornecimento. Nos anos 60 , estudos indicaram que a ocorrência dos fatores citados acima muito se devia à adoção de tecnologias exógenas, de alto custo operacional, requerendo mão-de-obra com habilidades técnicas, não disponíveis na região (MOTTA 1996).

O conceito de tecnologias apropriadas foi introduzido na década de 60 para alcançar resultados sociais e econômicos nos projetos de infra-estrutura dos países em desenvolvimento. Para MOTTA (1996) a tecnologia apropriada deve estar orientada para a população de menor renda e para as soluções das suas necessidades básicas. Além disso deve ser capaz de criar empregos, aumentar a renda e melhorar a produtividade da população pobre. Seus principios baseiam-se nos seguintes eixos norteadores: 
- Baixo custo relativo;

- Baixo investimento por posto de trabalho;

- Uso intensivo do trabalho em vez do uso intensivo do capital;

- Simplicidade no projeto e na construção;

- Facilidade na operação, manutenção e reparos;

- Pouco impacto ambiental ou de fácil reparo;

- Mercado definido;

- Utilização de recursos naturais locais;

- Baixo consumo de materiais e de energia;

- Fácil adaptação ao meio cultural.

OVALLES e VIEZZER (1995) ressaltam a aplicação do conceito de tecnologia apropriada a aquelas que, mesmo aparentemente simples, sem uso intensivo de energia e de capital, sejam capazes de atender os objetivos de um determinado programa.

Para ENNES (1989), a tecnologia apropriada é aquela que permite atender às comunidades com serviços de saneamento em condições sanitárias seguras e eficientes, que sejam aceitos pelas comunidades e que contemplem aspectos construtivos, operacionais e de custos compativeis com as características sócioeconômicas, ambientais e culturais das respectivas comunidades. A tecnologia apropriada não é alienígena, nem nacional, é ambas, se aplica em cada caso de acordo com as conveniências sócio-culturais e econômicas objetivando chegar a todos 0 benefício (CYNAMON 1987).

No caso específico do saneamento o uso de tecnologias apropriadas é uma condição necessária para que sejam conseguidos os resultados positivos de suas intervenções. Além da tecnologia apropriada relacionada com os aspectos de engenharia sanitária, a participação comunitária e o modelo operacional devem situar-se dentro dessa ótica. Segundo ANDRADE NETO 
(1999) "Quando há uma ativa participação coletiva nas decisões e na execução de um projeto, a ponto de a população local familiarizar-se e envolver-se emocionalmente com o mesmo, a comunidade passa a considerar a realização como própria, assume responsabilidade ao seu alcance e fará tudo para mantê-la" (p.3). Contudo, ressalta que não se pode esperar que a população local planeje algo que não sabe fazer, nem tampouco que assuma função técnica de legítima responsabilidade de engenheiros, como também não se pode desprezar a contribuição de técnicas especializadas na mobilização comunitária.

Segundo MARA e FEACHEN (1981), os sistemas de saneamento devem levar em conta fatores como:

- Educação Sanitária;

- Participação e comprometimento da comunidade no processo decisório;

- Tecnologia de simples manejo, com baixo custo operacional e de manutenção/reposição;

- Existência de instalações sanitárias prediais.

Caso contrário, os sistemas poderão apresentar problemas e até a própria falência após alguns anos de funcionamento, fazendo com que haja um recrudescimento na incidência de doenças de veiculação hídrica.

\subsection{Saneamento Rural no Modelo Central}

Em 1983, o Governo do estado da Bahia, por intermédio da Companhia de Engenharia Rural da Bahia - CERB e com financiamento do Banco Kreditanstalt für Wiederaufbau - KfW (Banco de Crédito para Reconstrução) da República Federal da Alemanha, executou um projeto denominado Saneamento Bahia I que consistiu na implantação de poços profundos e sistemas simplificados de abastecimento de água (distribuição por chafariz) 
em municípios das regiōes de Santa Maria da Vitória (região do Além São Francisco) e de Seabra e Caetité (região da Chapada Diamantina).

Esses sistemas foram repassados (mas não doados) para as associações comunitárias das localidades, mediante compromisso formal de operação/manutenção e de responsabilidade de custeio. Eventualmente, algumas prefeituras e a própria CERB contribuiam com recursos financeiros e/ou materiais, mas não de forma sistematizada que pudesse garantir uma efetiva continuidade dos sistemas, e dessa forma os sistemas foram se deteriorando progressivamente.

Em 1994, o Banco KfW constatou alguns problemas na gestão desses sistemas, especialmente no tocante à concepção do modelo gerencial, e decidiu por adotar uma reformulação voltada para um novo modelo, em que a operação seria feita por uma Federação das Associações Locais. Com o auxilio da estrutura de Engenharia e do Serviço Social da CERB, a Consultoria do Banco (GITEC) iniciou, em pequenas localidades que possuíam população residente entre 250 e 1.000 habitantes, um trabalho de organização das associações. A adesão ao sistema era efetivada mediante o pagamento, por parte dos moradores (chefes de família), de uma taxa inicial e do compromisso formal de pagamento pela água consumida. Essas associaçōes, por sua vez, formaram a Central de Associações Comunitárias para Manutenção de Sistemas de Abastecimento de Água - CENTRAL I, uma sociedade civil, sem fins lucrativos, com sede em Seabra, região da Chapada Diamantina, composta pelos presidentes das associações locais e por representantes das administrações municipais das localidades atendidas.

Os sistemas simplificados de abastecimento de água foram recuperados e adequados ao novo modelo, que previa o fornecimento de água domiciliar com micromedição. Para um consumo de cerca de 60L/hab.dia, a conta mensal de água foi estabelecida em torno de cinco reais, sendo dois reais e vinte centavos para a CENTRAL $\mathrm{l}$, e dois reais e oitenta centavos rateados 
entre o custo da energia elétrica consumida no bombeamento e a remuneração do operador local do sistema.

A CENTRAL I, sediada na cidade de Seabra, é constituída por 38 associações comunitárias de localidades de 20 municípios. Muitas dessas localidades distam mais de $100 \mathrm{~km}$ da sede da Central e o acesso é feito em estradas não pavimentada com tempo de viagem de cerca de 10 horas.

Em 1997, foi firmado um novo contrato de empréstimo entre o Governo do Estado da Bahia, por intermédio da CERB, e o Banco KfW da República Federal da Alemanha para o Programa de Saneamento Básico Bahia II, com o objetivo de implantação de sistemas de abastecimento de água e de esgotamento sanitário em outras 42 localidades e a criação da CENTRAL II. Dentro do programa foi também prevista, pela CERB, a construção de instalações sanitárias (vaso e ponto de chuveiro) nos domicílios e a implementação de ações locais de educação sanitária em conjunto com a comunidade, para melhorar a eficiência na utilização desses recursos por parte da população local.

A implantação dos sistemas de saneamento dentro do modelo da CENTRAL II apresenta alguns aspectos diferenciados que podem resultar em melhores benefícios à população. Dentre esses aspectos destacam-se:

- Criação de Associações de Moradores nas localidades, favorecendo uma base para futuras ações da comunidade em relação a outros tópicos de saneamento;

- Programa de educação sanitária pela equipe social (assistentes sociais e pedagogos), para a formação da associação, para a construção dos sistemas condominiais e para o uso do sistema, enfatizando-se o caráter condominial devido às imposições físicas e o seu modo gerencial, bem como a responsabilidade de cada morador (usuário) na sua preservação 
com vistas à redução de custos de reparos e à garantia do bom funcionamento por um maior período de tempo;

- Projeto de engenharia com técnicas adequadas à realidade local, de modo que a construção, e especialmente a operação do sistema, sejam passíveis de êxito, em condições de operação simplificada e com pouco recurso arrecadado;

O modelo Central de implantação e de operação de um sistema de saneamento deverá possivelmente ocasionar mudanças na qualidade de vida da população, que poderá ser percebida por diversos aspectos, tanto na melhoria do dia-a-dia da população, possibilitando novas atividades, quanto na redução de incidências de doenças de veiculação hídrica.

Considerando os dados apresentados, verifica-se a importância de estudos que investiguem de modo sistemático as mudanças que se relacionam entre a população e os sistemas de abastecimento de água e de esgotamento. A forma como ocorrem essas mudanças, os valores que a população dá à água como instrumento de melhoria da qualidade de vida, as relações da população com a água, os ganhos da população pela maior disponibilidade de água, são mudanças que requerem uma investigação contínua. $E$ nesse sentido, o presente trabalho é de interesse não apenas para a saúde pública, mas também para a viabilização e otimização dos recursos públicos aplicados em saneamento.

\section{$1.5 \quad$ Hipótese}

A implantação de um sistema de saneamento de água e de esgotamento sanitário que atende aos pressupostos das condições básicas de saneamento em uma comunidade promove a adesão da população local ao sistema e às mudanças nas práticas de higiene relacionadas com a água, com consequentes melhorias na saúde. 


\section{OBJETIVOS}

\subsection{Objetivo Geral}

Avaliar os resultados da implantação de um modelo de sistema associativo de saneamento com tecnologia apropriada nas condições de vida da população de comunidades rurais do semi-árido baiano.

\subsection{Objetivos Específicos}

- Estudar as principais mudanças dos hábitos sanitários da população após a implantação de um SAASES;

- Investigar a percepção da população com referência às melhorias na saúde após a implantação de um SAA/SES;

- Estudar os benefícios econômicos introduzidos nas condições de vida nas familias a partir da mudança da forma de aquisição de água para o consumo doméstico;

- Identificar as benfeitorias hidráulico-sanitárias prediais alavancadas pela implantação de um SAAVES.

- Verificar a relação entre a redução da incidência de diarréia infantil nas localidades estudadas e as condições do saneamento local após a implantação de um SAA/SES;

- Descrever o modelo de Saneamento Central II no aspecto de tecnologia apropriada de implantação e de operação. 


\section{METODOLOGIA}

\subsection{Tipo de Pesquisa}

Trata-se de uma pesquisa descritiva observacional, que toma como foco central a análise de um sistema de saneamento com tecnologia apropriada, a assimilação dos novos hábitos pela população e a comparação entre as condições de vida de uma população anterior e posteriormente à sua implantação.

\subsection{Objeto do Estudo}

O objeto de estudo dessa pesquisa é a comunidade de seis localidades atendidas por serviço de abastecimento de água e esgotamento sanitário operados pela Central II.

\subsection{Procedimentos Metodológicos}

\subsubsection{Levantamento Bibliográfico}

Foram feitos levantamentos bibliográficos através de sistemas bancos de dados e diretamente em bibliotecas e livrarias e internet.

\subsubsection{Levantamento Documental}

O levantamento documental foi feito nos arquivos da CERB e na CENTRAL II através de entrevistas com os funcionários dessas instituições que participaram na etapa da implantação e/ou no período atual de operação. 


\subsubsection{Identificação e Seleção das Localidades do Estudo}

A escolha das localidades de estudo baseou-se no critério: fonte de abastecimento de água utilizada anterior à implantação dos sistemas de saneamento da CENTRAL, considerando-se quatro diferentes tipos de fonte de água:

- Localidade que utilizava preferencialmente água de chuva e de um poço com rede de distribuição parcial;

- Localidade que utilizava preferencialmente água de rio;

- Localidade que utilizava preferencialmente água de açude;

- Localidade que utilizava preferencialmente água de poço/aguada ${ }^{(1)}$.

As localidades deveriam ser integrantes do Programa de Saneamento Bahia II (CENTRAL II) e estar sendo atendidas pelo Programa de Agente Comunitário de Saúde - PACS e pelo Sistema de Informação de Atenção Básica - SIAB por um período superior a um ano (6 meses antes e depois da implantação dos referidos sistemas). Como controle dos resultados de diarréia infantil, utilizaram-se os dados relativos de todas as localidades da Zona Rural do mesmo município, as quais, conforme informações das respectivas prefeituras municipais, não tiveram implantação e ou melhoria de sistema de abastecimento de água ou de esgotamento sanitário.

As localidades do programa Central que atenderam aos critérios quanto aos tipos de mananciais e de dados de diarréia infantil são apresentadas no tabela 1, a seguir, juntamente com as condições de disponibilidade de água no que se refere à quantidade e à qualidade.

\footnotetext{
${ }^{(1)}$ As aguadas são pequenas represas para acumulação de águas de chuva, cujo dique de barramento é geralmente um trecho de aterro da estrada de acesso. Aguadas próxima a uma localidade e em ponto mais baixo, geralmente recebem também as águas pluviais da localidade as quais carreiam partículas e todo tipo de resíduos sólidos.
} 
Tabela 1 Localidades da pesquisa e os tipos de mananciais existentes.

\begin{tabular}{|c|c|c|c|}
\hline Localidade & Manancial principal & $\begin{array}{c}\text { Qualidade da } \\
\text { Água }\end{array}$ & Disponibilidade \\
\hline Vila Cardoso & $\begin{array}{c}\text { Poço com chafariz/ } \\
\text { Rede (parcial)/ Aguada }\end{array}$ & Regular & Regular \\
\hline Gameleira & Aguada/Carro Pipa & Ruim & Pouca \\
\hline Jacunã & $\begin{array}{c}\text { Poço com Chafariz/ } \\
\text { Carro Pipa }\end{array}$ & Regular & Pouca \\
\hline Piaus & Açude/Carro Pipa & Regular & Boa \\
\hline Taquari & Açude & Regular & Boa \\
\hline Lajinha & Rio & Regular & Boa \\
\hline
\end{tabular}

\subsubsection{Amostra}

A pesquisa utilizou 3 grupos amostrais. O primeiro grupo amostral refere-se à população das localidades onde foram aplicados questionários em uma amostra aleatória da mesma. O segundo grupo refere-se a uma amostra intencional constituída dos presidentes das associações de moradores responsáveis pela operação dos sistemas de saneamento. O terceiro grupo refere-se ao universo populacional de crianças das localidades, menores de 2 anos, para informações relativas à diarréia infantil.

Para o cálculo do tamanho da amostra dos domicílios foram utilizadas as informações das plantas cadastrais das localidades do projeto, elaboradas em 1998 pela CERB, referentes ao número total de residências das localidades (1.740 residências), e adotados os seguintes parâmetros: grau de confiança de $95 \%$, poder de $80 \%$ e erro de $2 \%$. O tamanho da amostra calculado foi de 152 residências, porém a fim de se evitar possíveis perdas decorrentes da ausência de habitantes na residência, expandiu-se o tamanho da amostra para 174, o que corresponde a $10 \%$ do total das residências.

A escolha das residências foi feita numerando todas as casas constantes na planta baixa de cada localidade. Embora as características sócioeconômicas das residências sejam semelhantes, optou-se em escolher uma casa a cada grupo de 10 casas. O número sorteado foi o número 2 (dois). Dessa forma, o entrevistador deveria escolher as casas com término 2, ou 
seja, 2, 22, 32, 42, etc. Caso a residência estivesse fechada ou houvesse algum outro motivo que impedisse de se fazer a entrevista, o entrevistador passaria para o número seguinte. Se em campo fossem observadas novas construções estas seriam adicionadas à planta cadastral, numeradas em sequência, e incorporadas ao grupo de amostragem.

\subsubsection{Instrumentos de Coleta de Dados}

As informações da população referente às mudanças ocorridas na suas práticas diárias relacionadas com a água foram obtidas por intermédio da aplicação de um questionário estruturado com perguntas fechadas destinado a uma análise quantitativa, cujo questionário encontra-se no Apêndice $A$. $O$ questionário foi apresentado para os funcionários da Central, que por estarem frequentemente próximos à comunidade, poderiam apresentar sugestōes. Seu pré-teste foi aplicado em 10 residências de uma outra localidade integrante do programa Central. Após o pré-teste verificou-se a necessidade da reformulação de algumas questões para então a aplicação definitiva.

O questionário aplicado aos presidentes das associações de moradores das localidades -Apêndice B-, é do tipo estruturado com perguntas semi-abertas destinadas ao levantamento de informações referentes às mudanças ocorridas na comunidade após a implantação do sistema de saneamento.

As informações de diarréia infantil referem-se aos dados secundários de diarréia em crianças menores de 2 anos das localidades selecionadas para a pesquisa, registrados por Agentes Comunitários de Saúde - ACS dos respectivos municípios, e lançados pelas secretarias municipais de saúde no banco de dados SIAB. 


\subsubsection{Coleta de Dados}

Os dados referentes aos componentes de estrutura e de operação dos sistemas de saneamento foram obtidos pelas informações da CERB e da CENTRAL II. Para caracterização das localidades referentes às condições sócioeconômicas da população foram utilizadas informações da Fundação IBGE, DATASUS e CERB.

Os questionários destinados à população foram aplicados no mês de maio de 2002 por um profissional de pesquisa de campo com experiência comprovada em trabalhos similares e que também havia contribuído nos ajustes do questionário após a aplicação do pré-teste. Os questionários destinados aos presidentes das associações foram aplicados pelo próprio pesquisador, também no mês de maio de 2002.

Os dados de incidência mensal diarréia infantil em crianças com idade inferior a 2 anos registrados no SIAB foram coletados nas secretarias de saúde dos municípios das localidades da pesquisas uma vez que no banco de dados nacional e/ou estaduais, os dados disponíveis são os agrupados por município, porém, para a presente pesquisa, era necessária a informação desagrupada por localidade. O SIAB segue a definição de diarréia infantil adotada pela Organização Mundial de Saúde, que considera a condição de 3 evacuações ou mais por um indivíduo, liquefeitas, num período de 24 horas.

A coleta desses dados foi feita no mês de abril de 2002 fazendo-se uma varredura nos 9 municípios que possuíam localidades com o sistema de saneamento em questão implantado, verificando a efetiva existência e o seu período de registro do dado procurado (quantidade mensal de casos de diarréia em crianças menores de 2 anos), para então ser feita a identificação e seleção das localidades do estudo que atendessem à condição estabelecida no item 3.3.3. 
As visitas às localidades da pesquisa e às sedes de secretarias dos respectivos municípios para a coleta de dados possibilitaram um melhor conhecimento das realidades locais, visto que além da aplicação de questionários e a realização das entrevistas foi possivel uma interação pessoal em outro nível, o que segundo Minayo (2000) "constitui-se numa relação intersubjetiva, de integração social com o pesquisador, daí resultando um produto novo e confortante tanto com a realidade concreta, como com as hipóteses e pressupostos teóricos, num processo mais amplo de construção de conhecimentos". Essa relação permite apreender certas nuances que não apareceriam através das informações dos questionários ou das entrevistas, mas que, no entanto, são de interesse na compreensão do objeto estudado. Ainda segundo Minayo (2000), a observação participante, embora informal, não prescinde de um rigor teórico e prático visto que as conclusões tiradas em decorrência desse tipo de observação podem clarear ou obscurecer a realidade.

\subsubsection{Análise de dados}

Os dados foram analisados dentro da ótica dos componentes estruturais, operacionais e da comunidade.

Os efeitos na população foram avaliados através dos seguintes indicadores: mudança no valor do consumo per capita de água, valor e custo da água, tempo gasto para obtenção da água, mudanças nas práticas de higiene, melhoria na infra-estrutura sanitária da casa, percepção de melhoria na saúde, mudança na incidência de diarréia em crianças menores de 2 anos. As respostas referentes a práticas de higiene foram classificadas em 3 niveis relacionados com a segurança sanitária. Considerou-se Nivel 1 aquele em que as práticas têm pouca ou nula probabilidade de ocorrência de contaminação, o Nivel 2 aquele em que as práticas com médio potencial de contaminação e o Nível 3 aquele em que as práticas são consideradas sanitariamente inadequadas. A classificação das práticas relatadas dentro 
de um dos níveis baseou-se no critério do conhecimento prático teórico das consequências benéficas e maléficas à saúde que uma dada prática poderia causa.

A estrutura e o processo operacional da Central I foram analisados dentro do conceito de tecnologia apropriada utilizando os seguintes indicadores: taxa de cobertura, taxa de inadimplência, qualidade e frequência da água fornecida, frequência e duração das interrupções, operação e qualidade do efluente tratado, sustentabilidade da tarifa.

Para as análises estatísticas das variáveis sócioeconômicas, ambientais e comportamentais do estudo foram estimadas as medidas de tendência central e dispersão, média e desvio-padrão, respectivamente e as freqüências absolutas e percentuais. Essa análise contou com a participação de um profissional de estatísitca.

As informações coletadas por intermédio dos questionários aplicados nas residências foram processadas com o auxilio do programa EPI-INFO, versão 6.0, para o sistema operacional DOS. E as análises, bem como os teste estatísticos foram realizados no programa SPSS Win, versão 9.0. O nível de significância adotado para os teste estatísticos ( $p$ pareado) foi de $5 \%$ ou $p<=0,05$. As tabelas dos testes compõem o Apêndice $F$.

A respostas fornecidas pelos presidentes das associações, foram selecionados trechos que se relacionavam com o tema da questão proposta.

Especificamente para a avaliação do efeito na saúde da população, utilizouse como indicador a diarréia infantil em menores de 2 anos num delineamento do tipo ecológico, face ao tempo disponível, e à existência desses dados no SIAB. Segundo (FREITAS e col. 1990), este método melhor se aplica quando se está procurando um resultando global da ação de saneamento e não um âmbito individualizado por algum tipo de 
classificação de grupos da população. Nesse nivel de abordagem mais totalizadora, não há lugar para o isolamento de variáveis simples, de inspiração biológica. Um estudo ecológico pode sintetizar um conjunto enorme de variáveis, aproximando mais esse tipo de estudo da realidade social concreta (ALMEIDA FILHO e ROUQUARYOL 1990). 


\section{CARACTERIZAÇÃO DAS LOCALIDADES E DOS SISTEMAS DE SANEAMENTO}

\subsection{Caracterização das Localidades}

Todos os municípios das localidades da pesquisa pertencem à região do estado denominada Piemonte da Chapada Diamantina (CEI 1994). Segundo a classificação de Koepen, o clima dessa região é do tipo Aw, que consiste de um clima tropical quente com precipitação média anual variando entre 500 e $1.000 \mathrm{~mm}$. Particularmente, na área da pesquisa, no semestre mais seco (maio a outubro), a precipitação média não ultrapassa o valor de $175 \mathrm{~mm}$, ao passo que no semestre mais úmido (novembro a abril), o valor alcança $327 \mathrm{~mm}$ (CERB 1996). A temperatura média é de $23,5^{\circ} \mathrm{C}$, a umidade relativa do ar de $69 \%$, a insolação anual é $2.097,2$ horas e a evaporação anual é de $1.767,3 \mathrm{~mm}$. A região apresenta temperatura mínima média anual de $18,7^{\circ} \mathrm{C}$ e a máxima média anual de $30,3^{\circ} \mathrm{C}$ (CERB 1996). De acordo com o relatório Riscos e Secas na Bahia (CEI 1991), o risco de seca é alto em toda a região. A figura 2 a seguir apresenta o mapa do estado da Bahia, destacando a localização dos municípios e das localidades da pesquisa. 


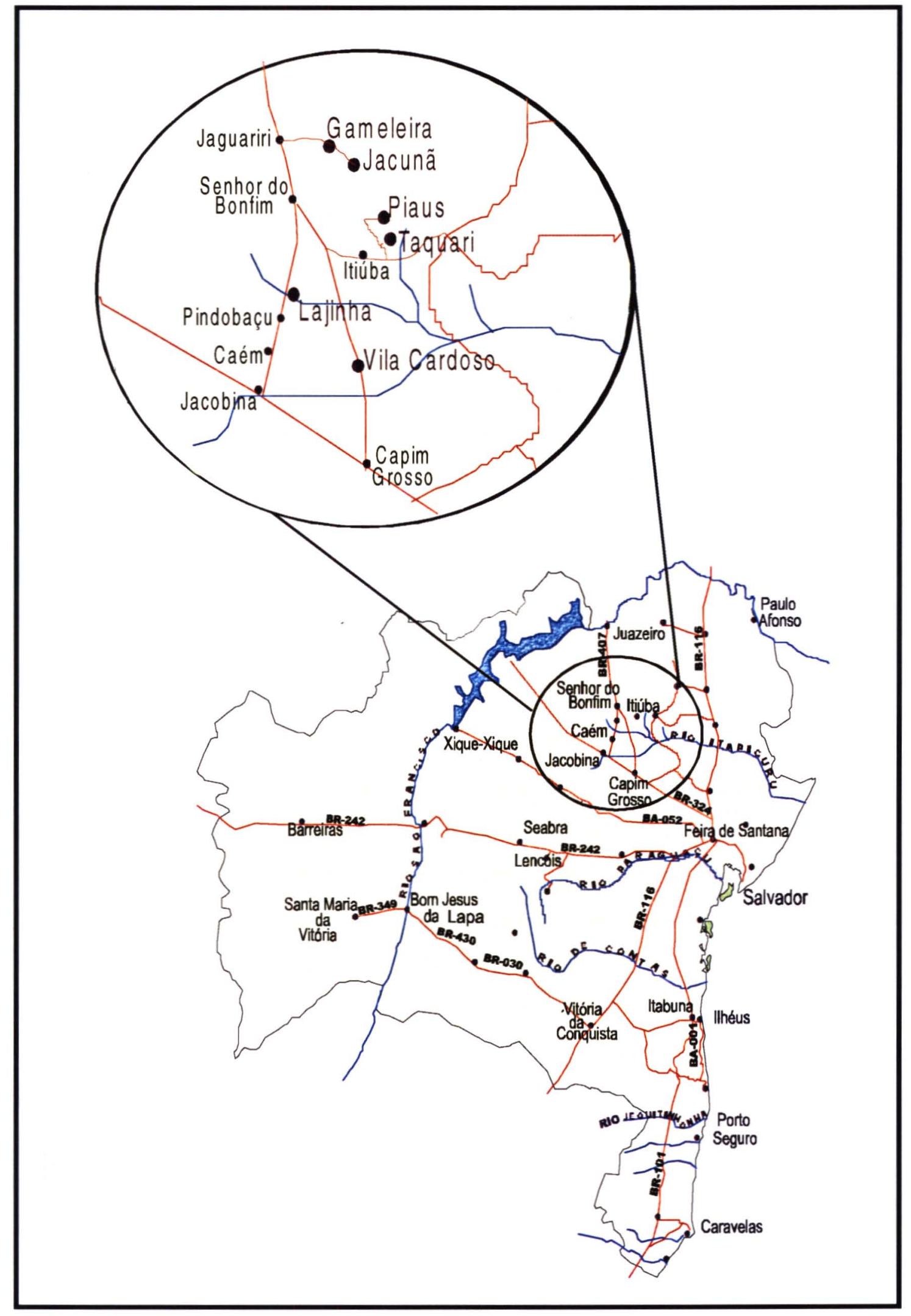

Figura 2 Mapa do estado da Bahia com indicação das localidades da Desauisa 
A atividade econômica predominante é a agro pecuária, havendo também o extrativismo mineral, em especial o garimpo de esmeralda e de ouro, e a mina de cobre da Caraibas Metais no município de Jaguarari Da atividade agrícola, a pecuária (predominando o rebanho bovino e caprino) evidenciase como a mais importante atividade econômica com cerca de $50 \%$ das terras dos estabelecimentos rurais destinadas à pastagem, porém, para a lavoura, são dedicados menos de $10 \%$ da área total (PLANARQ 2001). As pastagens naturais predominam nos estabelecimentos rurais, característica de região com baixo índice de desenvolvimento tecnológico. A pesca nos açudes da região destina-se predominantemente para a subsistência e para o consumo local. $\mathrm{Na}$ agricultura verifica-se o predomínio das lavouras temporárias sobre as permanentes. Mais de $70 \%$ dos estabelecimentos praticam agricultura temporária de subsistência de feijão, mandioca ou do apoio à pecuária, como a palma, cana de açúcar e milho. Os pólos de comércio regionais são as cidades de Jacobina e Senhor do Bonfim.

As localidades selecionadas para a pesquisa têm uma estrutura similar, com arruamento definido, com a construção ocupando toda a testada do lote, cuja área é na maioria dos casos inferior a $200 \mathrm{~m}^{2}$. O padrão construtivo é de uma casa com sala, cozinha, dois quartos, sendo o sanitário de diversos tipos (interno, externo, casinha, ou ausente). Em um levantamento cadastral realizado nas localidades integrantes do programa em 1998 pela CERB (CERB 1998f), cerca de 90\% das casas são próprias, com paredes de tijolo ou adobe e piso cimentado ou revestido com cerâmica. Em todas as localidades há escola de ensino fundamental e posto de saúde onde uma auxiliar de enfermagem realiza pequenos curativos, vacinação, medição de pressão arterial, etc. A tabela 2 a seguir apresenta informações referentes a aspectos sócio-econômicos dos municípios, segundo dados da Fundação IBGE. 
Tabela 2 Informações socioeconômicas dos municípios de Caém, Jaguarari, Itiúba e Pindobaçu, estado da Bahia, 2000.

\begin{tabular}{|c|c|c|c|c|}
\hline INFORMAÇŌES & CAÉM & JAGUARARI & PINDOBAÇU & ITIÚBA \\
\hline Área & $498 \mathrm{Km}^{2}$ & $5.267 \mathrm{Km}^{2}$ & $528 \mathrm{Km}^{2}$ & $1.731 \mathrm{Km}^{2}$ \\
\hline População Residente (2000) & 12.562 & 27.395 & 20.813 & 35.550 \\
\hline População Residente (1991) & 17.116 & 31.141 & 24.047 & 34.403 \\
\hline População Residente (1996) & 17.120 & 37.365 & 24.551 & 34.804 \\
\hline População Urbana (2000) & 3.374 & 13.376 & 10.413 & 8.857 \\
\hline População Rural (2000) & 9.188 & 14.019 & 10.400 & 26.693 \\
\hline Posto de Saúde (1999) & 0 & 6 & 3 & 2 \\
\hline Centro de Saúde (1999) & 5 & 1 & 1 & 1 \\
\hline Óbitos (1998) & 59 & 121 & 47 & 114 \\
\hline Mortalidade Infantil (/1.000 nascidos vivos) & 72,10 & 70,05 & 70,09 & 70,05 \\
\hline Óbitos Doença Infecciosas e Parasitárias (1998) & 1 & 2 & 1 & 3 \\
\hline Receita Orçamentária & $\mathrm{R} \$ 2.729 .000,39$ & $\mathrm{R} \$ 6.274 .701,15$ & $\mathrm{R} \$ 4.059 .152,84$ & $\mathrm{R} \$ 3.664 .414,14$ \\
\hline Pessoas residentes- 10 anos ou mais de idade alfabetizada & 6.889 & 16.170 & 11.528 & 19.078 \\
\hline Domicílios Particulares Permanentes & 2.887 & 7.112 & 5.278 & 8.216 \\
\hline Dom. Part. Perm. C/ Banheiro, ou Sanitário - Esgoto Rede Geral & 5 & 2.440 & 353 & 659 \\
\hline Dom. Part. Perm. Forma de Abast. de Água - Rede Geral 2000 & 1.104 & 4.315 & 2.983 & 2.782 \\
\hline Domicílios Particulares Permanentes Destino de Lixo Coletado & 1.034 & 3.523 & 3.597 & 1.764 \\
\hline Hospitais & 1 & 1 & 1 & 2 \\
\hline Leito Hospitalar & 44 & 30 & 35 & 71 \\
\hline Unidades Ambulatoriais (1999) & 6 & 8 & 5 & 6 \\
\hline Matrícula Ensino Fundamental & 4.206 & 8.682 & 6.167 & 10.136 \\
\hline Matrícula Ensino Médio & 353 & 1.484 & 543 & 806 \\
\hline Estabelecimentos de Ensino Fundamental & 44 & 77 & 42 & 148 \\
\hline Estabelecimentos de Ensino Médio & 3 & 6 & 2 & 2 \\
\hline Nascidos Vivos & 471 & 897 & 496 & 1.346 \\
\hline Valores do Fundo de Participação dos Municípios & $\mathrm{R} \$ 2.377 .092,95$ & $\mathrm{R} \$ 3.565 .639,11$ & $\mathrm{R} \$ 2.773 .274,88$ & $R \$ 3.181 .942,87$ \\
\hline
\end{tabular}




\subsubsection{Vila Cardoso}

A localidade de Vila Cardoso situa-se à margem da rodovia BR-407. Sua denominação popular é "Quilômetro Trinta" dado que a localidade (como muitas no estado da Bahia) originou-se a partir da implantação de um posto de combustivel, o qual se localiza a $30 \mathrm{~km}$ da cidade mais próxima, Capim Grosso. As atividades econômicas são basicamente agricultura de subsistência, pequeno comércio local e comércio e serviço de apoio aos viajantes que transitam pela rodovia. Pela facilidade de transporte, muitos dos moradores também trabalham em cidades próximas, especialmente Capim Grosso, que se situa mais próximo do que a sede do município a que pertence (Caém). A população prevista, pela CERB em 1998, era de 1.350 habitantes.

Seu relevo é ondulado e a maioria das ruas não possui calçamento, havendo apenas um trecho calçado na margem da rodovia e no largo onde é realizada a feira semanal. A localidade possui um posto de saúde, uma creche e duas escolas pública do ensino fundamental.

Anteriormente à implantação do Sistema CENTRAL II, o abastecimento de água era realizado de forma precária, utilizando a água de um poço localizado a cerca de 600 metros da comunidade. O sistema anterior abastecia cerca $40 \%$ das residências da localidade, porém o fornecimento era precário com paradas freqüentes devido a problemas do sistema de recalque. Opcionalmente a população utilizava água da chuva armazenada e de uma aguada existente junto à localidade, que recebe as águas drenadas na área da cidade e que é também utilizada para lavagem de roupas, animais, etc. Não havia sistema coletivo de esgotamento sanitário. No questionário aplicado pela CERB em 1998 (CERB 1998f), a população reclamava do esgoto a céu aberto, da presença de porcos soltos e do lixo. $O$ lixo gerado na localidade é disposto inadequadamente a céu aberto em uma 
área situada no outro lado da rodovia, em frente à localidade. A Figura 3 apresenta uma vista parcial da localidade.

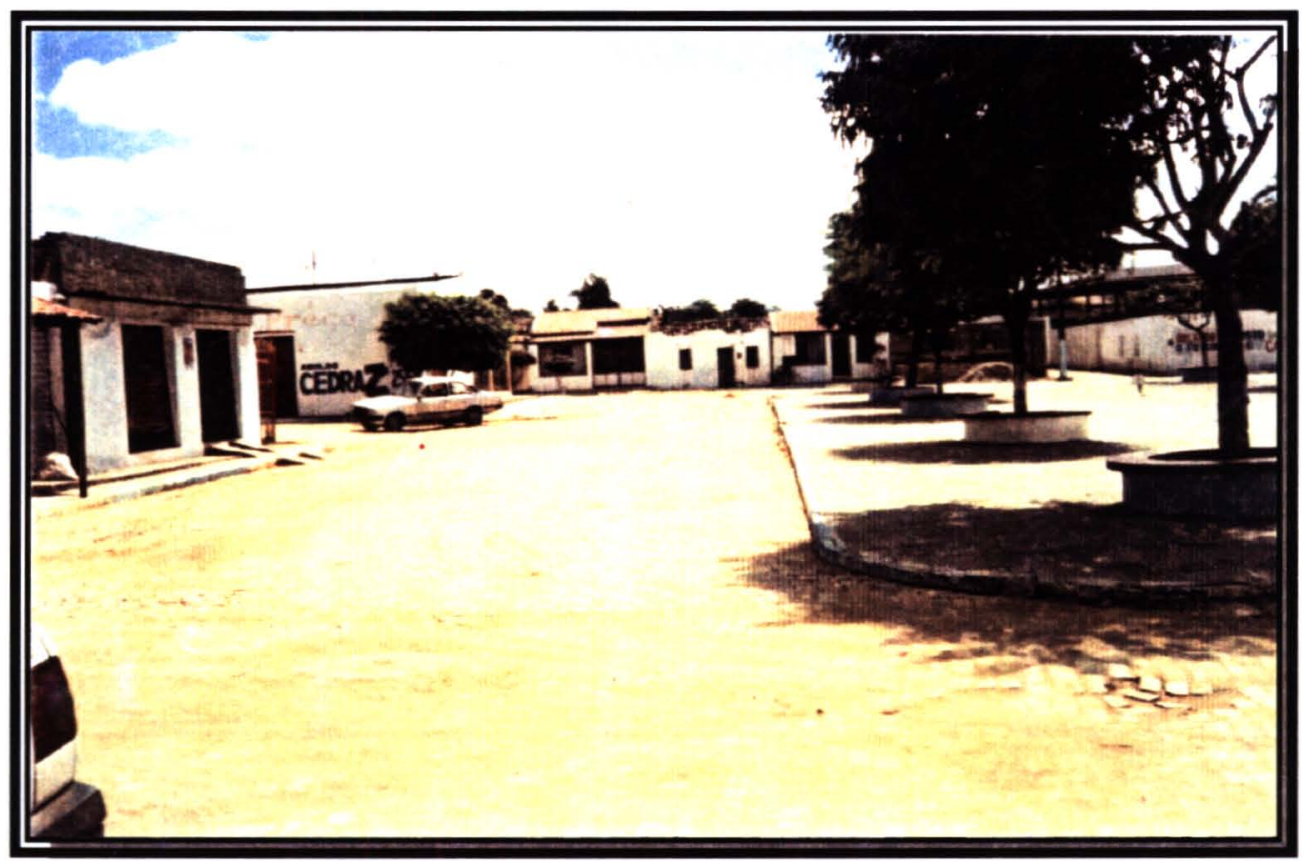

Figura 3 Vista parcial de Vila Cardoso.

\subsubsection{Gameleira}

O acesso a esta localidade é feito pela rodovia BR-407 (junto à cidade de Jaguarari), seguindo $16 \mathrm{~km}$ de estrada sem pavimento. A população prevista, pela CERB em 1998, era de 2.755 habitantes, cujas atividades econômicas são basicamente agricultura e pecuária de subsistência e pequeno comércio local. A localidade possui espaço coberto para feira, um matadouro de animais, armazéns, oficina mecânica, um posto de saúde e uma escola pública do ensino fundamental e ginásio com quadra de esporte.

Anteriormente ao programa de saneamento não havia sistema público de abastecimento de água. A população utilizava a água de uma aguada situada junto à localidade, visivelmente contaminada, de caminhão pipa e da coleta de água de chuva. Não havia também sistema coletivo de esgotamento sanitário. As Figuras 4, 5 e 6 a seguir mostram aspectos dessa localidade. 


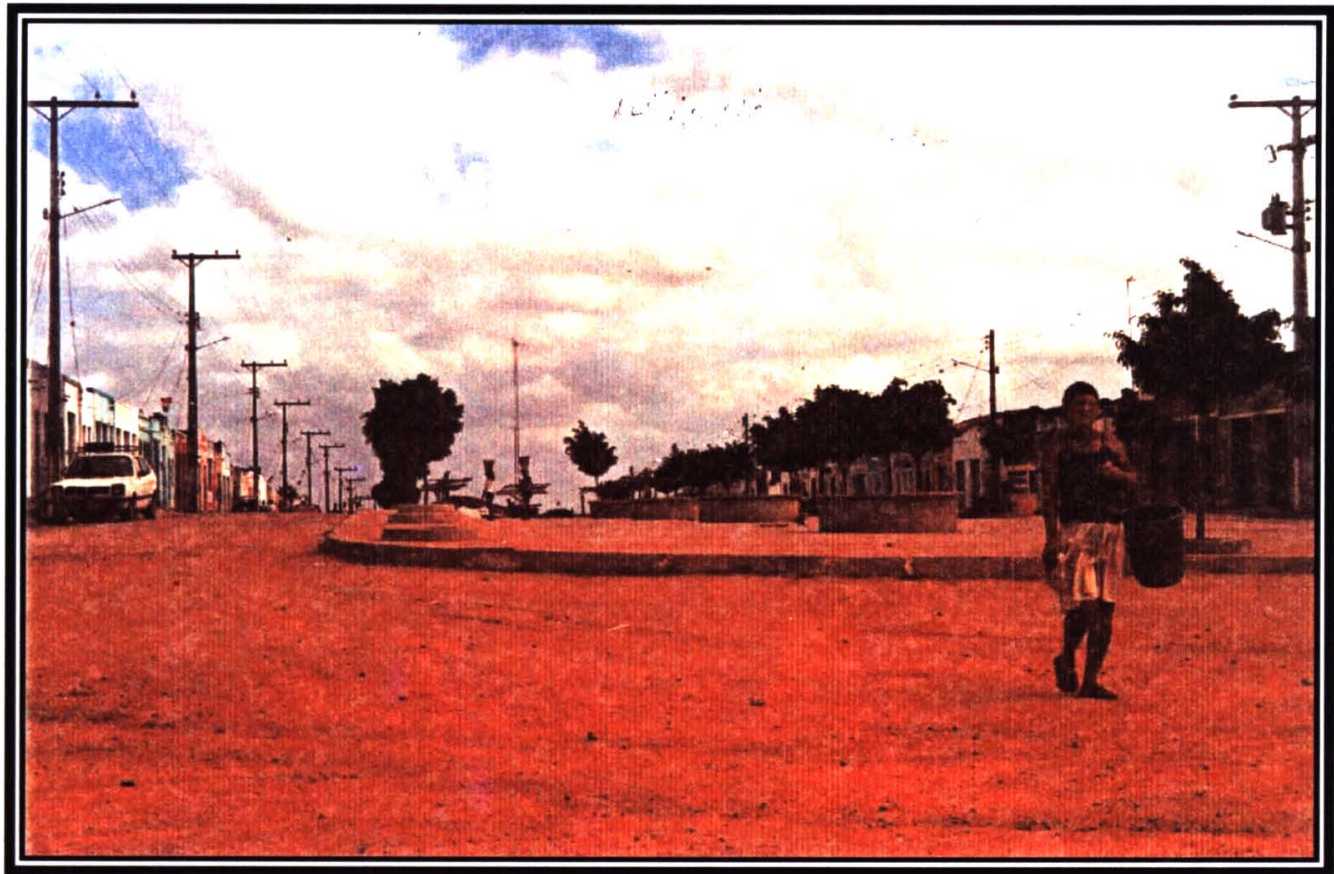

Figura 4 Vista parcial de Gameleira.

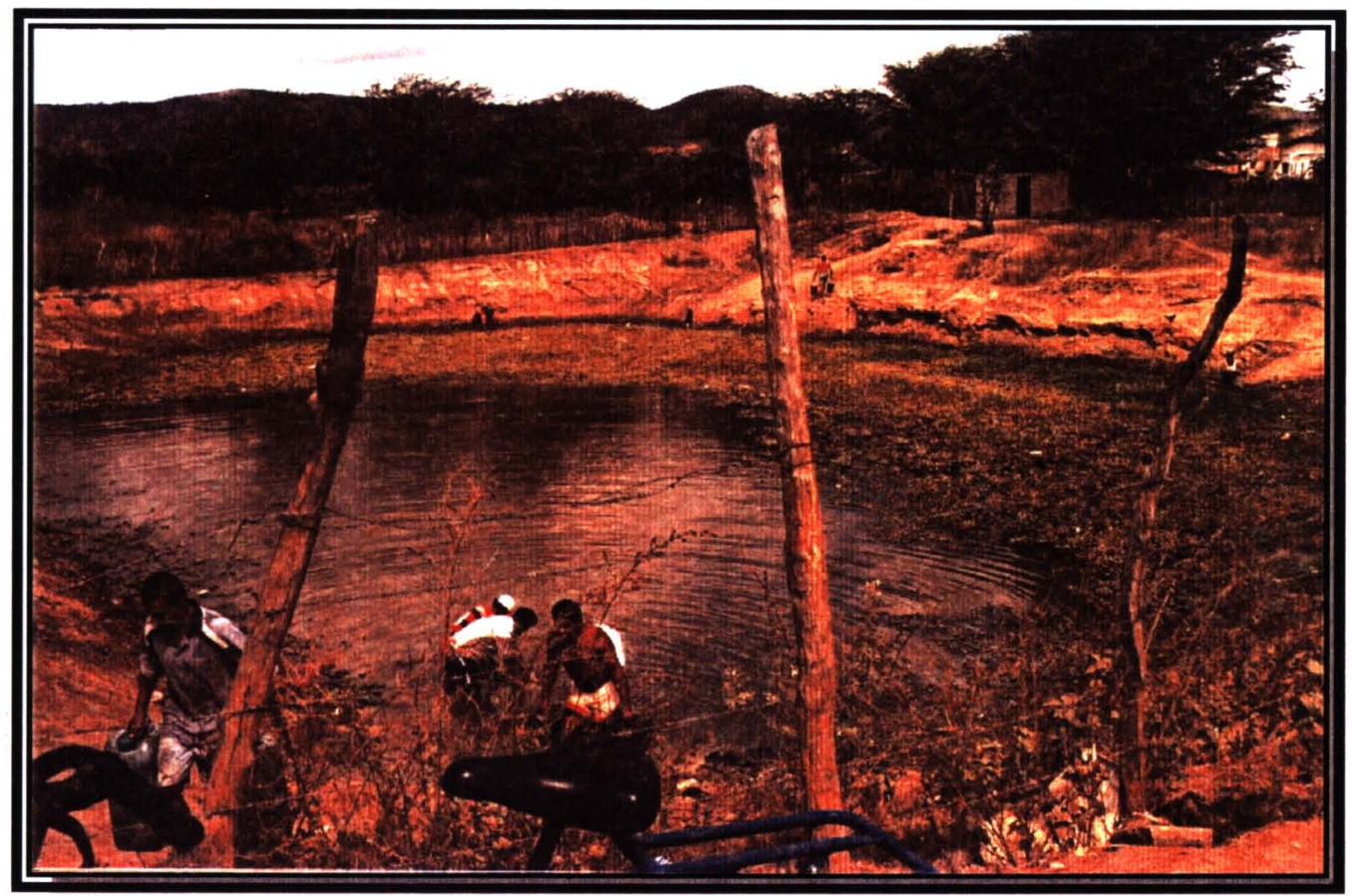

Figura 5 Aguada utilizada anteriormente pela população de Gameleira. 


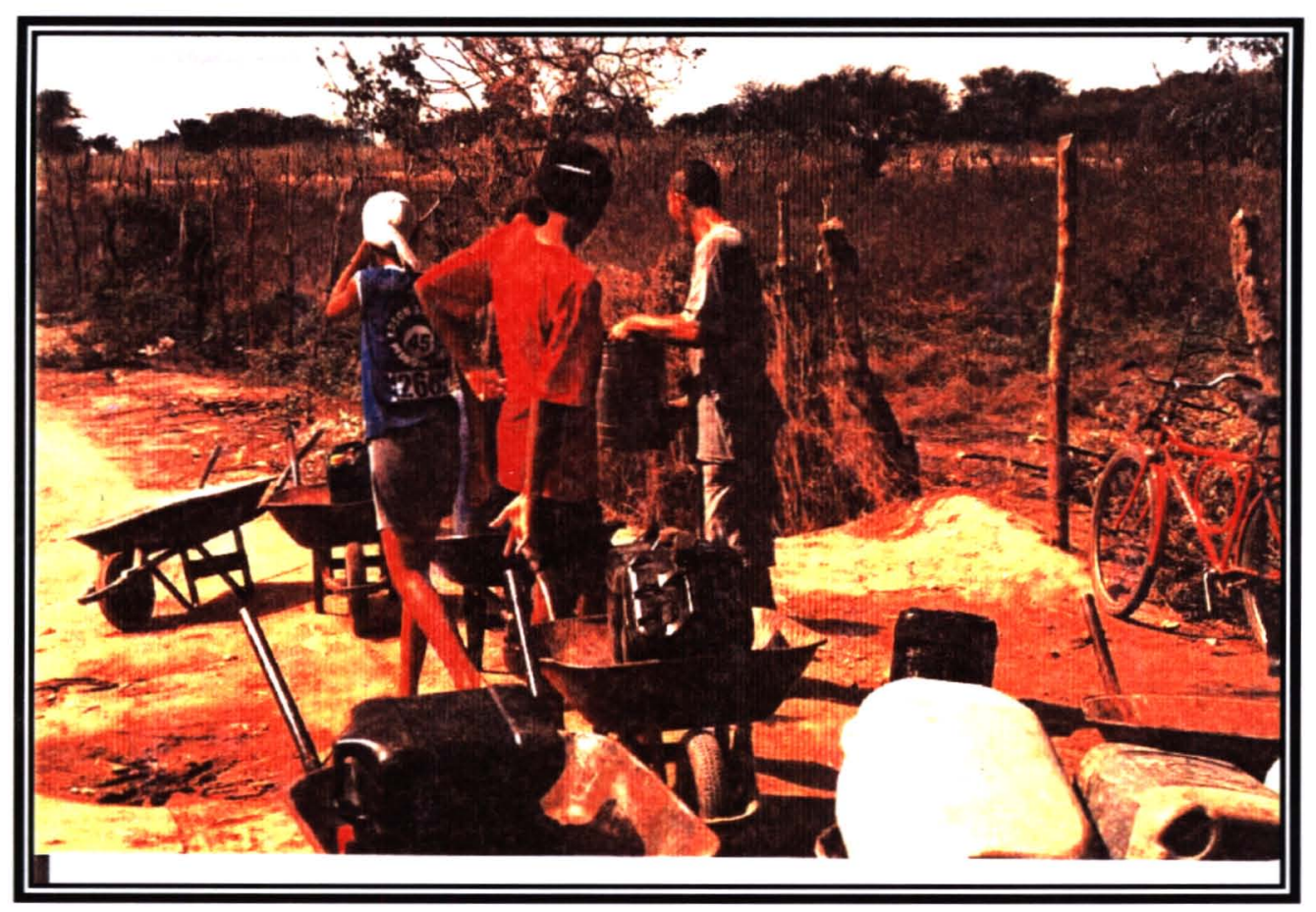

Figura 6 Aguadeiros de Gameleira.

\subsubsection{Jacunã}

A localidade de Jacunã situa-se a $4 \mathrm{~km}$ da localidade de Gameleira, cujo acesso se dá pela rodovia BR-407 (junto à cidade de Jaguarari), seguindo $20 \mathrm{~km}$ de estrada sem pavimento. A população prevista, pela CERB em 1998, era de 1.220 habitantes, cujas atividades econômicas são basicamente agricultura e pecuária de subsistência e pequeno comércio local. A localidade possui um posto de saúde e uma escola pública do ensino fundamental. Apenas as ruas principais são pavimentadas com paralelepípedo.

Anteriormente ao programa de saneamento não havia sistema público de abastecimento de água. A população utilizava água de um poço situado junto à localidade, de caminhão pipa e da coleta de água de chuva. Não havia sistema coletivo de esgotamento sanitário. As figuras 7 e 8 a seguir mostram aspectos desta localidade. 


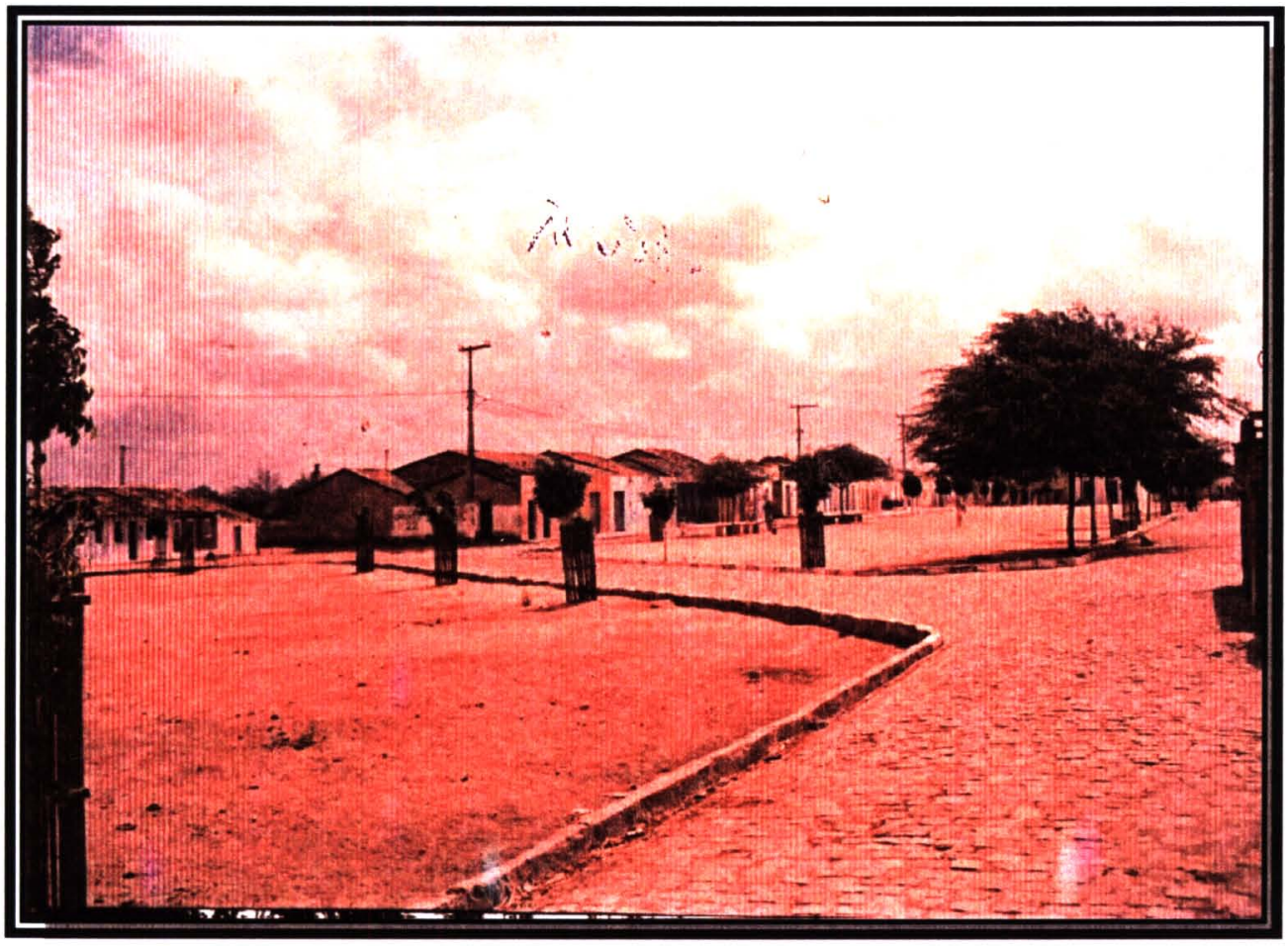

Figura 7 Vista parcial de Jacunã.

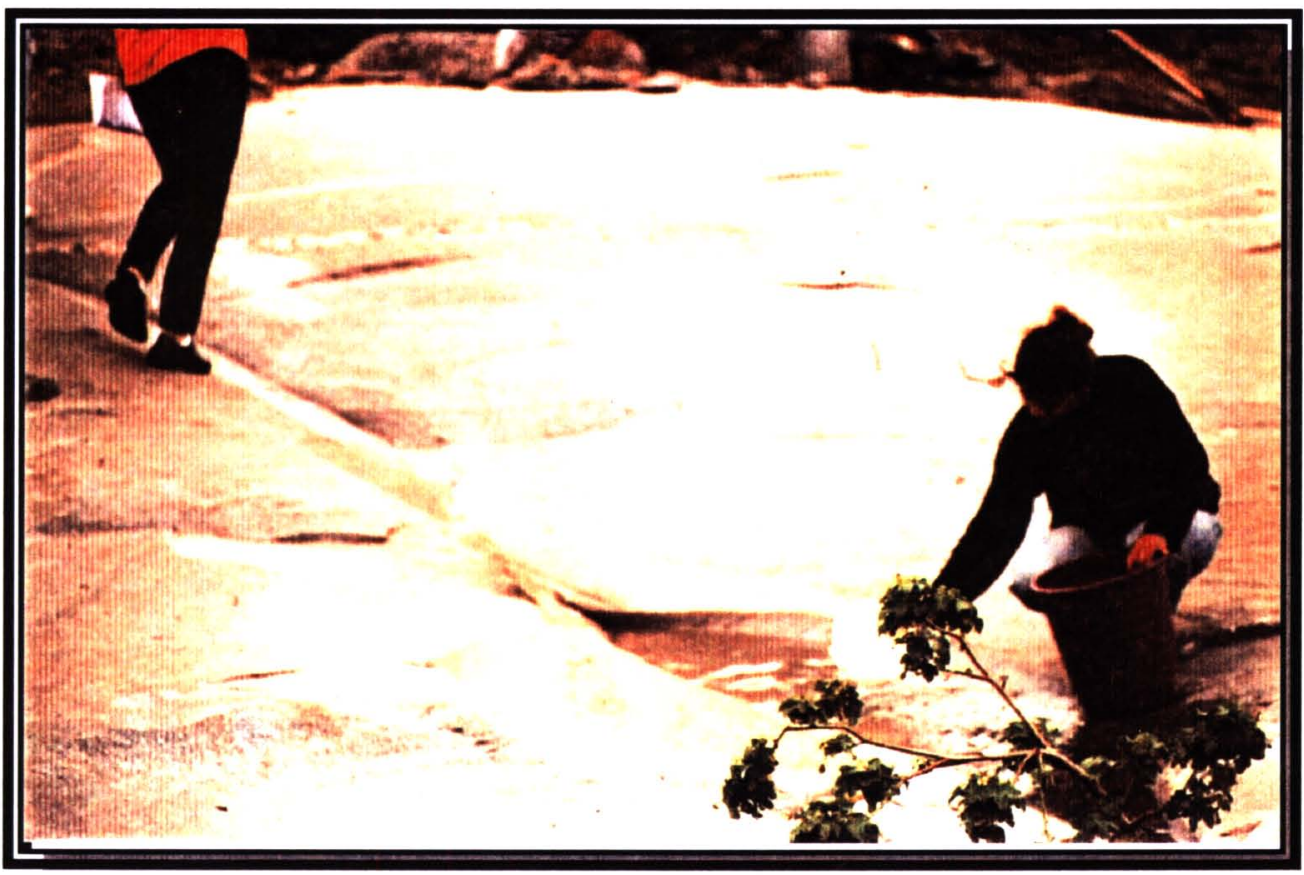

Figura 8 Moradora de Jacunã coletando água de chuva acumulada em uma depressão da pedra em 1999. 


\subsubsection{Piaus}

A localidade de Piaus situa-se na margem direita do açude de Jacurici. Seu acesso dá-se a partir da sede municipal, percorrendo $16 \mathrm{~km}$ em asfalto pela BA-381 e $14 \mathrm{~km}$ em estrada de barro. Esta localidade originou-se com a construção do açude que atraiu pessoas para a pesca e sua comercialização, sendo essas, juntamente com um pequeno comércio e serviço para a população da região e a agricultura de subsistência, as atividades econômicas básicas da população local, cuja previsão feita pela CERB em 1998, foi de 1.780 habitantes.

A localidade possui espaço coberto para a feira que se realiza semanalmente, um campo de futebol, um posto de saúde e uma escola pública do ensino fundamental.

Anteriormente, o abastecimento de água era feito através de um poço com dessalinizador e chafariz, os quais encontravam-se desativados por falta de manutenção. A população utilizava água do açude, água de chuva e de caminhão pipa.

O lixo gerado na localidade é disposto em terrenos baldios da localidade, atraindo animais como porcos, galinhas e vetores de doenças.

\subsubsection{Taquari}

A localidade de Taquari situa-se a cerca de $4 \mathrm{~km}$ da localidade de Piaus, e também na margem direita do açude de Jacurici. Seu acesso dá-se a partir da sede municipal, percorrendo $16 \mathrm{~km}$ pela BA-381 e $10 \mathrm{~km}$ em estrada de barro. Como Piaus, sua origem ocorreu a partir da criação do lago deste açude. A conformação do relevo local permite à população da região utilizar o açude como balneário no final de semana, sendo atualmente uma fonte de 
renda para os moradores locais, além da pesca e da agricultura de subsistência. A população prevista, pela CERB em 1998, era de 460 habitantes. $O$ relevo é ligeiramente ondulado com ruas sem calçamento. $A$ localidade é contornada por duas fazendas de gado, cujos proprietários não vendem nem arrendam área, restringindo assim as possibilidades de expansão da mesma. A localidade possui um posto de saúde e uma escola pública de ensino fundamental.

Anteriormente à implantação do sistema de abastecimento e de esgotamento da CENTRAL II, o abastecimento de água era feito por intermédio do açude, em locais onde também se faziam outros usos. A água era transportada através de baldes ou por um sistema particular improvisado com uma bomba centrífuga e uma pequena adutora. A água era vendida. $A$ maioria das casas não possuía sanitário.

O lixo gerado na localidade é acrescido ao gerado pela população flutuante do final de semana que contribui com embalagens descartáveis como latas de bebidas e invólucros de plástico e de alumínio. $O$ acumulo de lixo causa reclamações e prejuízos para os barraqueiros da borda do açude. A Prefeitura Municipal de Itiúba faz ocasionalmente uma limpeza da área.

\subsubsection{Lajinha}

A localidade de Lajinha situa-se na margem da rodovia BA-134, junto ao rio do Aipim, à jusante da barragem do Aipim. Dista $16 \mathrm{~km}$ da sede do município e $18 \mathrm{~km}$ da cidade de Senhor do Bonfim. A população prevista pela CERB em 1998 era de 610 habitantes, cujas atividades econômicas são basicamente agricultura e pecuária de subsistência, pequeno comércio e serviço local e para apoio aos viajantes que transitam pela rodovia. Pela facilidade de transporte, muitos dos moradores também trabalham em cidades próximas, como Pindobaçu, Cândido Sales e Senhor do Bonfim. 
A maioria das ruas é calçada. A localidade possui um posto de saúde, uma creche e uma escola de ensino fundamental com classes da $1^{\underline{a}}$ a $4^{\underline{a}}$. Os estudantes da $4^{\text {a }}$ a $8^{\text {a }}$ série cursam em escola da sede municipal com transporte fornecido pela prefeitura municipal.

Anteriormente ao programa de saneamento, as condições sanitárias eram precárias e não havia sistema público de abastecimento de água, sendo a água do rio o principal manancial. Não havia sistema de esgotamento sanitário e a presença de rocha a pouca profundidade dificultava inclusive a construção de fossa seca.

O lixo gerado na localidade é disposto inadequadamente em uma área no outro lado da rodovia em frente à localidade.

As tabelas 3 e 4 a seguir apresentam um resumo das principais características das localidades do projeto.

Tabela 3 Tipo de abastecimento de água das localidades antes e depois ao programa de saneamento.

\begin{tabular}{|l|l|l|}
\hline Localidade & \multicolumn{1}{|c|}{ Antes } & \multicolumn{1}{c|}{ Depois } \\
\hline Vila Cardoso & Poço/Aguada & Poço/Reservatório/Rede de Distribuição \\
\hline Gameleira & Aguada/Caminhão Pipa & Poço/Reservatório/Rede de Distribuição \\
\hline Jacunã & Poço/Caminhão Pipa & Poço/Reservatório/Rede de Distribuição \\
\hline Piaus & Açude/Caminhão Pipa & Filtro Lento/Reservatório/Rede de Distribuição \\
\hline Taquari & Açude/Distribuição particular & Filtro Lento/Reservatório/Rede de Distribuição \\
\hline Lajinha & Rio & Poço/Reservatório/Rede de Distribuição \\
\hline
\end{tabular}


Tabela 4 Acesso às localidades da pesquisa

\begin{tabular}{|l|l|}
\hline \multicolumn{1}{|c|}{ Localidade } & \multicolumn{1}{|c|}{ Acesso } \\
\hline Vila Cardoso & $\begin{array}{l}\text { Margem da rodovia BR 407, 30km ao norte da cidade de Capim } \\
\text { Grosso. }\end{array}$ \\
\hline Gameleira & $\begin{array}{l}16 \mathrm{~km} \text { em estrada de barro ao leste da BR 407 iniciando em frente à } \\
\text { cidade de Jaguarari }\end{array}$ \\
\hline Jacunã & $\begin{array}{l}\text { 20km em estrada de barro ao leste da BR 407 iniciando em frente à } \\
\text { cidade de Jaguarari }\end{array}$ \\
\hline Piaus & $\begin{array}{l}14 \mathrm{~km} \text { em estrada de barro ao norte da BA 381, 16km após a cidade de } \\
\text { ltiúba. }\end{array}$ \\
\hline Taquari & $\begin{array}{l}10 \mathrm{~km} \text { em estrada de barro ao norte da BA 381, 16km após a cidade de } \\
\text { ltiúba. }\end{array}$ \\
\hline Lajinha & $\begin{array}{l}\text { Margem da rodovia BA 134, 18km ao sul da cidade de Senhor do } \\
\text { Bonfim. }\end{array}$ \\
\hline
\end{tabular}

\subsection{Central II}

As localidades estudadas nesta pesquisa têm seus sistemas de abastecimento de água e de esgotamento sanitário operados pela CENTRAL II - Central de Associações Comunitárias para Manutenção de Sistemas de Abastecimento de Água, que opera um total de 32 localidades integrantes do programa de Saneamento Bahia II. No momento, a população atendida é de cerca de 27.000 habitantes, sendo que as estruturas foram dimensionadas e implantadas para um período de 20 anos, quando se prevê o atendimento para aproximadamente o dobro da população atual.

A Central tem sua origem em um programa de implantação e de gerenciamento da operação de sistemas de abastecimento de água e de esgotamento sanitário, denominado Programa Bahia II, firmado entre o Governo do Estado da Bahia e o Banco Alemão KfW, com um investimento de 20.500.000 DM (Marco Alemão), sendo 12.500.000 DM provenientes do empréstimo do Governo da Bahia junto ao banco a serem pagos em 20 anos com juros de 4\% ao ano com 2 anos de carência, 7.000.000 DM, como contrapartida do Estado e 1.000.000 DM, a título de fundo perdido, doados pelo KfW para serem aplicados na estruturação da CENTRAL II. 
A CENTRAL II foi fundada em 1998. É sediada na cidade de Jacobina e formada pelas associações comunitárias filiadas, tendo como coparticipantes as prefeituras das respectivas localidades, a CERB e o KfW. Os órgãos administrativos e deliberativos da Central são:

- A Diretoria, com seis membros: presidente, vice-presidente, tesoureiro e segundo tesoureiro, secretário e segundo secretário;

- O Conselho Deliberativo, com três membros da Diretoria, um representante das associações comunitárias indicado pela Assembléia, dois representantes de prefeituras, um representante da CERB e um representante do $\mathrm{KfW}$;

- O Conselho Fiscal, com seis membros, sendo três efetivos e três suplentes.

O objetivo principal da Central (conforme o capítulo II do estatuto) é garantir o funcionamento dos sistemas de abastecimento de água dos associados. Toda a água fornecida é medida e cobrada com vistas ao funcionamento e à manutenção dos sistemas de abastecimento de água de esgotamento sanitário. As taxas são computadas pelo volume mensal de água consumido por cada ligação predial e medido por hidrômetros. O consumo mínimo mensal é de $10 \mathrm{~m}^{3}$. Uma assembléia geral é realizada anualmente quando são apresentadas a prestação de contas, a relação das atividades e as propostas para reajustes de taxas.

As localidades do Programa Bahia II foram selecionadas observando a distância entres as mesmas e a sede da Central para facilitar a prestação de serviços de manutenção e a emissão e controle das contas diretamente pela Central II com base na leitura fornecida pelas associações comunitárias (operadores).

Nas comunidades do Programa Bahia II foram construídos sistemas de esgotamento sanitário: convencional, condominial ou individual. A 
manutenção e a operação destes sistemas necessitam de um acompanhamento mais freqüente, especialmente no início, quando a população ainda está se familiarizando com o uso e também de cuidado para evitar o entupimento, diferentemente das comunidades do Programa Bahia I, em que foram instaladas privadas secas, que não representam custo de manutenção para a Central I. Segundo a Central, muitas dessa privadas já foram transformadas em banheiros sanitários e chuveiro.

A Central II iniciou o seu funcionamento em $1999 \mathrm{com} 120 \mathrm{~m}^{2}$ em Jacobina onde estão instalados o escritório, o almoxarifado e a oficina para reparos dos hidrômetros e das bombas. O escritório possui a infra-estrutura básica, com telefone, fax, computador, espaço para reunião e pequenos treinamentos equipados com televisor, vídeo cassete e retroprojetor. $O$ escritório é ainda alugado, havendo previsão da compra de uma sede própria. Um automóvel e um caminhão são utilizados para os deslocamentos entres as localidades e para o transporte de equipamentos e um equipamento portátil para remoção de lodo de tanque séptico. O quadro de pessoal consiste em um gerente administrativo, um gerente técnico, um técnico de manutenção, um agente de desenvolvimento comunitário e um auxiliar de escritório. Não há motoristas, faxineiras ou copeiras, nem vigilantes sendo todos responsáveis pelas atividades de limpeza e manutenção geral das instalações da sede. A remuneração dos funcionários varia de $R \$ 350,00$ a 500,00 por mês, sendo que os dois gerentes recebem gratificação de um salário mínimo.

Os sistemas de abastecimento de água possuem outorga para captação de água fornecida pela Superintendência de Recursos Hídricos do Estado da Bahia - SRH e a outorga de lançamento de efluentes tratados onde há corpo d'água receptor encontra-se em processo de análise. A Central não possui ainda a concessão municipal de exploração do serviço de fornecimento de água e de esgotamento sanitário. 
O processo de formação da Central iniciou-se com a visita da equipe técnica da CERB formada por profissionais de Serviço Social, e Ciências Sociais que efetuam contatos com as prefeituras e lideranças locais. A partir daí visitam todas as residências de cada localidade para explicar os objetivos do programa e convidam para uma assembléia de formação da associação, em cujo estatuto estaria prevista a operação do sistema de abastecimento de água e de esgotamento sanitário.

Para a formação da associação com o citado objetivo, na assembléia deveria haver o aceite de no mínimo de $70 \%$ dos presentes às condições de fornecimento de água determinadas pelo programa quais sejam hidrometração e pagamento pela água consumida.

Segundo a equipe técnica da CERB, em todas as localidades já havia uma associação de moradores sendo o trabalho da equipe reformulá-la para o citado fim, bem como estruturá-la em auxílio a contabilidade, formação de regimento, etc. A associação paga uma taxa de ingresso para a Central, seguindo posteriormente, das taxas mensais.

Quando da implantação do sistema de saneamento, a equipe social retorna à localidade para atividades de educação sanitária em toda a comunidade e de formação dos síndicos das quadras da rede condominial de esgotamento sanitário. No final da obra a equipe assessora a associação para o recebimento do sistema de saneamento. As figuras 9 e 10 mostram momentos das reuniões com a comunidade. 

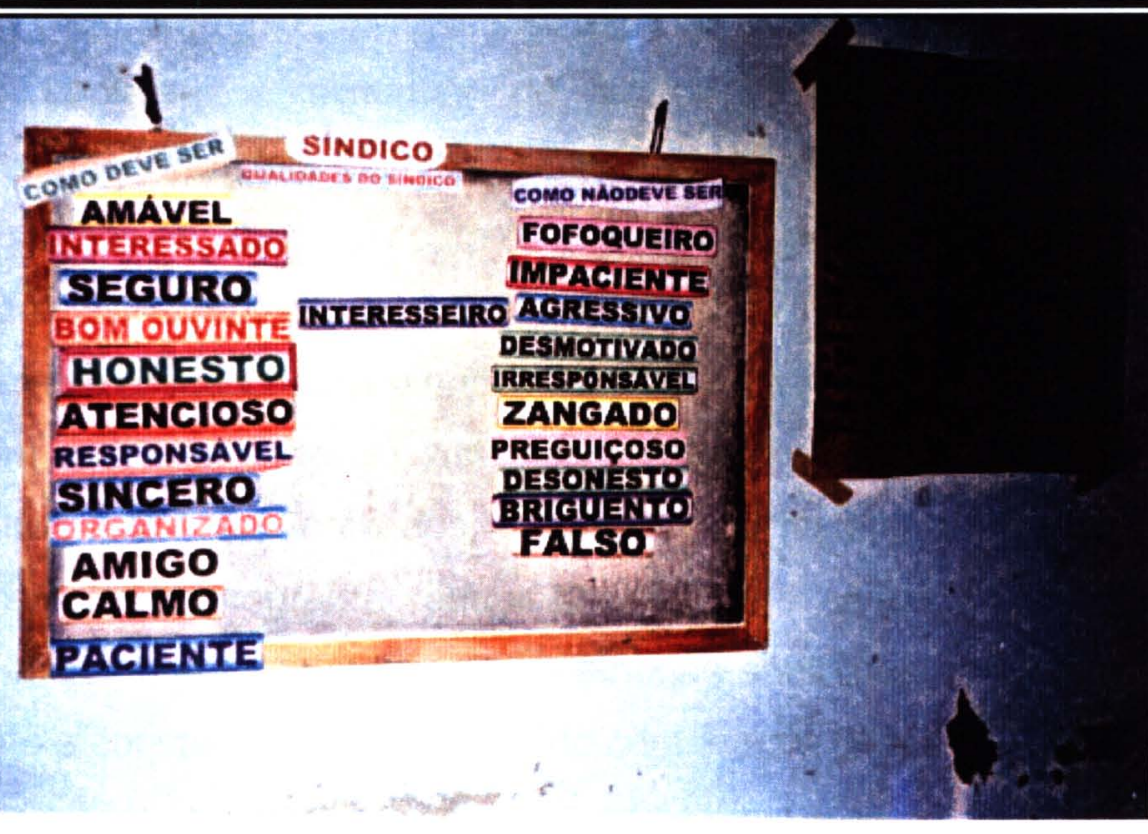

Figura 9 Critérios para escolha do síndico da quadra do esgotamento condominial em Vila Cardoso definidos em reunião da comunidade.

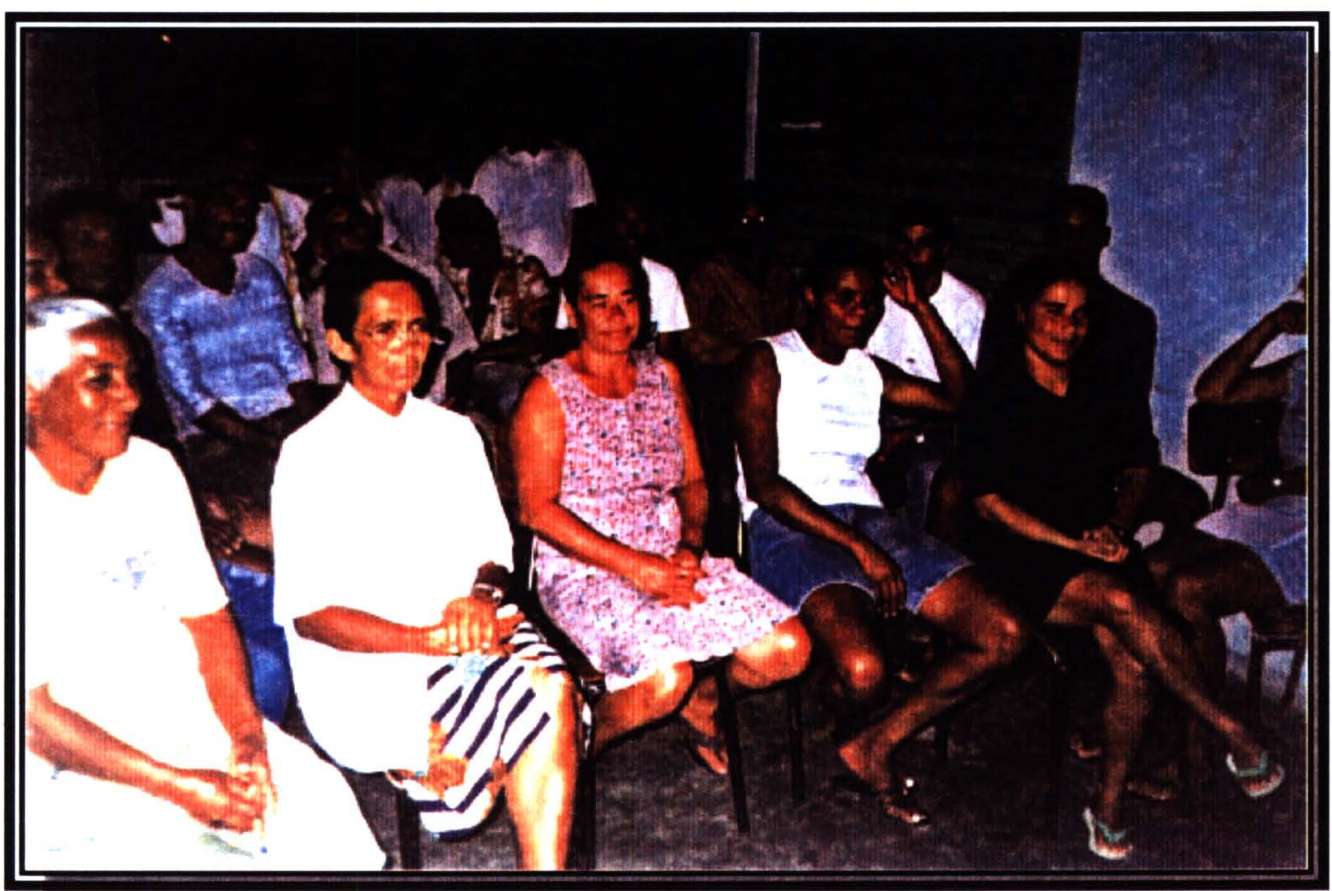

Figura 10 Reunião da comunidade em Vila Cardoso. 
O programa Central II visou inicialmente atender apenas as localidades em que foram implantados sistemas de abastecimento de água e de esgotamento sanitário pelo convênio Bahia II. Novas localidades que já possuem sistemas de abastecimento de água podem ser incorporadas, mas a filiação dessas novas associações comunitárias requer que o sistema existente seja modificado para atender às exigências do padrão técnico da Central, com automatização do sistema, bomba submersa padronizada e quadro de comandos padronizados, e hidrômetros instalados em todas as ligações prediais. O programa requer também que sejam implantados o sistema de esgotamento sanitário e as melhorias sanitárias nas residências (basicamente a construção de um sanitário com vaso e descarga).

A operação dos sistemas fica a cargo das Associações de Moradores Locais que é também responsável pelo pagamento da conta de energia elétrica da estação elevatória e do salário do operador, cabendo a este efetuar:

- A medição do consumo de água e cobrança da conta de água,

- A operação e limpeza do clorador;

- A limpeza das áreas do poço de captação e da estação de tratamento de esgoto;

- Pequenos reparos de vazamento na rede de distribuição de água e nos barriletes;

- Desobstrução da rede de esgotamento sanitário e da estação de tratamento de esgoto.

A Central encarrega-se da manutenção preventiva do sistema e reparos, controle de perdas, emissão das contas de água, assessoria às associações e trabalho com a comunidade.

Os operadores dos sistemas são moradores das próprias localidades, selecionados e treinados pela equipe social da CERB e pelos técnicos da equipe da Central em práticas operacionais e instalações prediais e 
conhecimentos básicos de saúde ambiental e tratamento de água e de esgotamento sanitário.

Os técnicos da Central foram inicialmente treinados pelo SENAI, na fábrica das bombas utilizadas nos sistemas de água (Bomba Leão), no Liceu de Artes e Ofícios de São Paulo, em Sobral, no Ceará, junto ao SISAR, e em Santa Catarina, junto à CASAN, (ambos programas financiados com empréstimos do KfW) para a operação e manutenção dos sistemas de esgotamento sanitário e filtros lentos.

O pessoal administrativo e os dirigentes das associações comunitárias (presidentes, tesoureiros, secretários e conselheiros fiscais) foram treinados pela equipe da CERB e por empresas de consultoria em contabilidade, associativismo e saúde ambiental, havendo cursos de reciclagem a cada seis meses. Há também um intercâmbio entre as duas Centrais, tanto de informações como na troca de peças e equipamentos.

O compromisso da Central é de reparar os sistemas que apresentarem problemas operacionais dentro de um prazo de 48 horas. No entanto, existem roteiros para a manutenção preventiva, como uma frequência trimestral e de visitas de inspeção para verificar as perdas e ligações clandestinas e efetuar cortes. Como os sistemas de água possuem macro e micro medição, é possível fazer um controle efetivo do volume aduzido e do volume total faturado.

A Central cobra uma taxa para a manutenção dos sistemas de abastecimento de água, não incluindo a conta de energia elétrica e o salário do operador. Essas despesas são pagas separadamente, conforme estabelecido pela associação comunitária, havendo inclusive a possibilidade (a exemplo da Central I), de a associação fazer um acordo com a prefeitura local para esta pagar a conta de energia e/ou o salário do operador, cabendo à Central acompanhar os valores que estão sendo pagos. 
O estudo de viabilidade da Central é baseado na filiação de pelo menos cinco mil ligações prediais, a partir da consideração das despesas de reposição de peças e equipamentos e de administração/operação da própria Central (escritório, pessoal, transporte, etc.). Atualmente a Central II possui 6.000 ligações prediais de abastecimento de água, o que representa uma arrecadação mensal de aproximadamente $R \$ 24.000,00$. Cabe ainda ao Governo do Estado a coordenação geral do programa e da Central II através de uma consultoria, além da assistência técnica, através da CERB, de reparos de poços profundos e eventuais perfurações de novos poços, caso sejam necessárias.

A Central promove ainda alguns cursos especiais para formação geral como os cursos de "Dinâmica das Águas Subterrâneas" para operadores e "A Mulher e sua Atuação na comunidade". Existe também um programa com o objetivo de manter o contato com os seus usuários, em que as associações comunitárias filiadas são convidadas a indicar estudantes com interesse em trabalhar no escritório da Central durante as férias, por um período de no máximo dois meses. Durante este período, o estudante tem a oportunidade de aprender a trabalhar com computador, controle de estoque, banco de dados, controle de pagamento, etc. Como estímulo à regularidade de pagamento das contas de água, a Central premia mensalmente a associação que melhor mantém os pagamentos, o controle e os recibos em dia. A associação vencedora recebe um conjunto de material de escritório, camisas ou relógios com o logotipo da Central. No final do ano, a associação comunitária que permaneceu mais vezes em primeiro lugar, ganha a taça "Associação do Ano" e um conjunto de uniforme (camisa, calção, meia e bola) para seu time de futebol.

Como meio de divulgação com os usuários, a Central publica mensalmente um pequeno jornal no qual são informadas as situações dos sistemas de abastecimento de água e de esgotamento sanitário, eventos e cursos, a situação financeira e notícias diversas relacionadas ao interesse das 
comunidades, em especial ao assunto água e saúde. Faz-se também uma campanha constante, solicitando à população que utilize a água da Central apenas para o abastecimento humano e utilize água de cacimbas, tanques, etc para irrigação e dessedentação de animais, dada às dificuldades de obtenção de água subterrânea em certas áreas e que os sistemas foram projetados apenas para o consumo humano.

A Central é registrada como de Instituição de Utilidade Pública Estadual e Federal possibilitando, assim, se habilitar a receber verbas oficiais, subvenções de deputados, recursos de organizações internacionais e gozar isenções fiscais.

\subsection{Sistemas de Abastecimento de Água e de Esgotamento Sanitário Implantados}

\subsubsection{Sistema de Abastecimento de Água}

Os sistemas de abastecimento de água implantados pelo programa Saneamento Bahia II nas localidades da pesquisa compõem-se, na maioria dos casos, de Captação em Poço Profundo, seguido de Bombeamento para o Reservatório e Rede de Distribuição. A exceção se faz para as localidades de Piaus e Taquari, cujo manancial é de água superficial (Açude de Jacurici) e sem potabilidade natural, sendo necessário um tratamento, que é feito por Filtro Lento antecedido por um Pré Filtro.

Os projetos previram o abastecimento de água para toda a população residente na localidade e a do meio disperso situada a até 50 metros da adutora e, para isso, a tubulação de saída do reservatório foi dimensionada para a vazão de rede de distribuição (vazão máxima horária). A taxa de crescimento populacional adotada foi de $3,53 \%$ ao ano, resultando no dobro da população inicial após 20 anos (final de projeto) e o consumo per capita de água adotado de $80 \mathrm{~L} / \mathrm{hab}$.dia com um coeficiente de retorno para esgoto 
de 0,8. A seguir são apresentados os principais dados dos sistemas de abastecimento de água.

\subsubsection{Vila Cardoso}

Manancial subterrâneo com captação em poço tubular com profundidade de 83 metros, recalcando $7,10 \mathrm{~L} / \mathrm{s}$ a uma altura manométrica de $93,90 \mathrm{~m} . c . a$. A adutora é em PVC DN 150, e possui uma extensão de 1.964 metros conduzindo para um reservatório com volume de $150 \mathrm{~m}^{3}$. A partir do reservatório segue a rede de distribuição, sendo 2.496 metros de linha tronco (DN 150) e 3.708 metros no trecho urbano com diâmetros de 150 , 100 e $75 \mathrm{~mm}$ (CERB 1998a).

\subsubsection{Gameleira e Jacunã}

As localidades de Gameleira e Jacunã têm um Sistema de Abastecimento de Água Integrado, cujo manancial são dois poços tubulares com profundidades de 120 e 95 metros. O sistema de adução é constituído por três adutoras, sendo as duas primeiras destinadas para conduzir a água recalcada dos poços para uma Chaminé de Equilíbrio e a terceira para conduzir, por gravidade, para o Reservatório de Distribuição de $280 \mathrm{~m}^{3}$, que alimenta as redes de distribuição de Gameleira e Jacunã (CERB 1998b). As adutoras e as redes de distribuição possuem as características apresentadas nas tabelas 5 e 6 a seguir: 
Tabela 5 Características das adutoras do sistema de abastecimento de água de Gameleira e Jacunã

\begin{tabular}{|c|c|c|c|c|}
\hline \multirow{2}{*}{ Adutoras } & \multicolumn{4}{|c|}{ Características } \\
\cline { 2 - 5 } & Diâmetro $(\mathbf{m m})$ & Material & Extensão $(\mathbf{m})$ & Tipo \\
\hline Adutora I & 75 & Aço Galvanizado & 33,77 & Recalque \\
Poço VI & 100 & DEFoFo & 124,78 & \\
\hline Adutora II & 75 & Aço Galvanizado & 34,62 & Recalque \\
Poço V & 100 & DEFoFo & 77,14 & \\
\hline Adutora III & & & & \\
Trecho 1 & 150 & DEFoFo & $5.530,64$ & Gravidade \\
Trecho 2 & 150 & FoFo & 90,64 & Gravidade \\
Trecho 3 & 100 & FoFo & 661,00 & Gravidade \\
Trecho 4 & 100 & DEFoFo & 681,84 & Gravidade \\
Trecho 5 & 100 & FoFo & 573,56 & Gravidade \\
Trecho 6 & 100 & DEFoFo & $1.245,19$ & Gravidade \\
Trecho 7 & 100 & FoFo & 1995,95 & Gravidade \\
\hline
\end{tabular}

Tabela 6 Rede de distribuição de água das localidades de Gameleira e Jacunã.

\begin{tabular}{c|c|c}
\hline \multirow{2}{*}{ Diâmetro (mm) } & \multicolumn{2}{|c}{ Extensão (m) } \\
\cline { 2 - 3 } & Gameleira & Jacunã \\
\hline 50 & 4.230 & 2.042 \\
\hline 75 & 1.459 & 249 \\
\hline 100 & - & 993 \\
\hline 150 & 468 & 311 \\
\hline 200 & - & 1.561 \\
\hline Total & $\mathbf{6 . 1 5 7}$ & $\mathbf{5 . 1 5 6}$ \\
Fonte: CERB (1998b). & &
\end{tabular}

\subsubsection{Piaus e Taquari}

As localidades de Piaus e Taquari possuem um sistema de abastecimento de água integrado que utiliza o Açude Jacurici como manancial de abastecimento, onde uma captação flutuante conduz água através de mangotes, para a Caixa de Transição, daí seguindo por uma adutora para a Estação de Tratamento de Água, que possui um Reservatório de Regulação de Vazões, um Pré - Filtro de Fluxo Ascendente, Filtros Lentos e o Reservatório Apoiado. Este, com as finalidades de Tanque de Contato, Reservatório de Distribuição para a localidade de Taquari e Poço de Sucção da Estação Elevatória que conduz a água tratada para o Reservatório Elevado de distribuição da localidade Piaus (CERB 1998c). As principais características dessas unidades são apresentadas a seguir: 
Adução com o primeiro trecho em mangote flexível de pressão com 250 metros de extensão e DN 100 e o segundo trecho em PVC DN 100 com 1.700 metros de extensão.

Pré Filtro com área de $24,54 \mathrm{~m}^{2}$ (taxa de filtração de $18 \mathrm{~m}^{3} / \mathrm{m}^{2}$.dia) e Filtro Lento com duas células filtrantes e (taxa de filtração de $5 \mathrm{~m}^{3} / \mathrm{m}^{2}$ ).

Estação Elevatória de Água Tratada para Piaus com vazão de 3,95 l/s, altura manométrica de 29,04 m.c.a. e potência instalada de 5CV enviando a água para o reservatório de Piaus com volume de $75 \mathrm{~m}^{3}$. O reservatório de Taquari é o próprio tanque de contato da cloração e o poço de sucção do recalque para Piaus. A seguir são apresentadas as redes de distribuições na Tabela 7 e uma vista da estação de tratamento com Filtro Lento na figura 11.

Tabela 7 Rede de distribuição de água das localidades de Piaus e Taquari

\begin{tabular}{c|c|c}
\hline \multirow{2}{*}{ Diâmetro (mm) } & \multicolumn{2}{|c}{ Extensão $(\mathbf{m})$} \\
\cline { 2 - 3 } & Piaus & Taquari \\
\hline 50 & 3.339 & 1.033 \\
\hline 75 & 1.454 & - \\
\hline 100 & 177 & 1.706 \\
\hline 150 & 17 & - \\
\hline Fonte: CERB (1998c) & $\mathbf{4 . 9 8 7}$ & $\mathbf{2 . 7 3 9}$
\end{tabular}




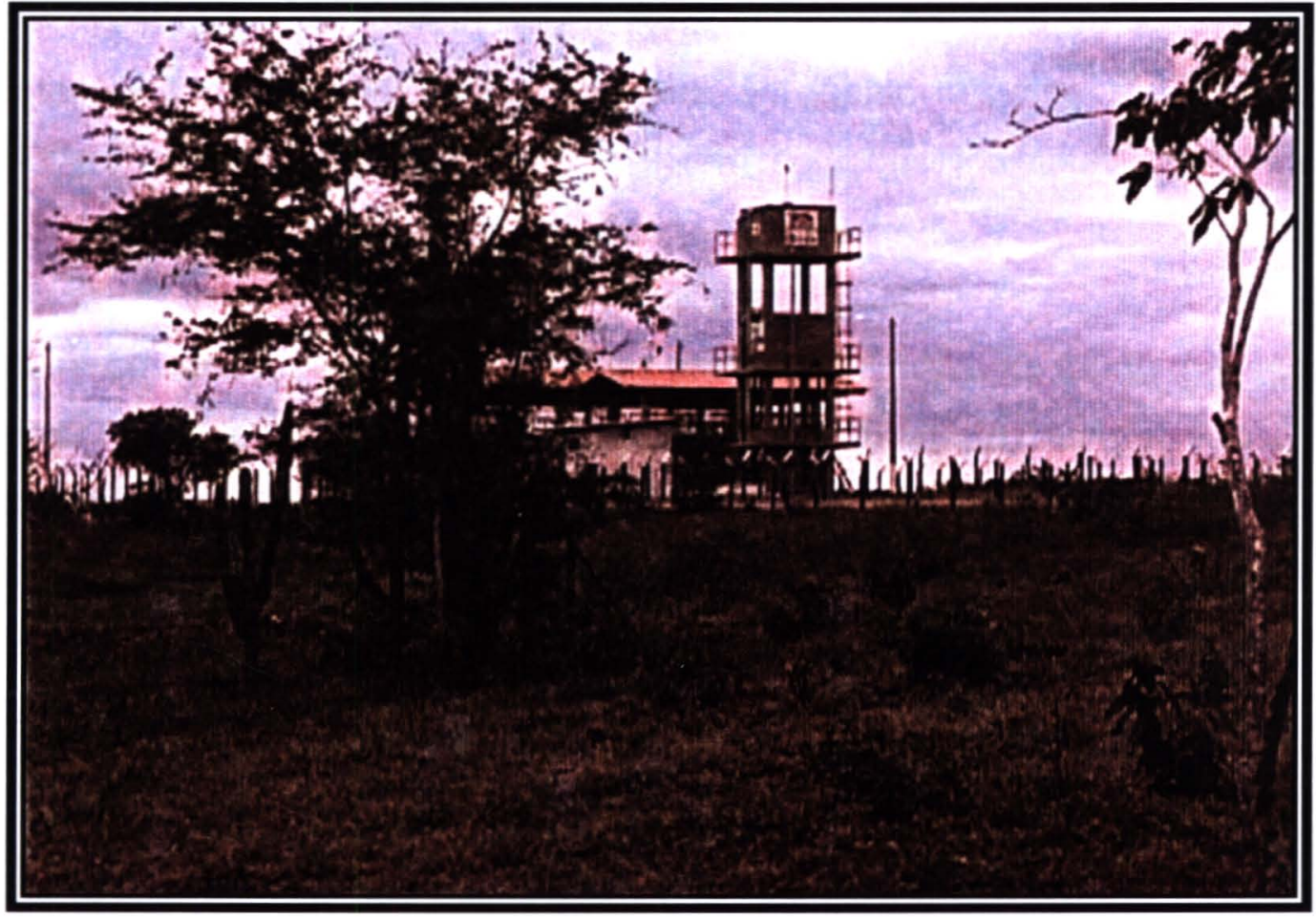

Figura 11 Estação de Tratamento de Água com Filtro Lento para Piaus e Taquari.

\subsubsection{Lajinha}

Manancial subterrâneo com captação em Poço Tubular com profundidade de 117 metros, vazão de $8,46 \mathrm{~L} / \mathrm{s}$, elevando a uma altura manométrica de 55 m.c.a. para um reservatório com volume de $100 \mathrm{~m}^{3}$ através de uma adutora em PVC DN 100 e 170 metros de extensão (CERB 1998d).

A partir do reservatório tem-se a rede de distribuição com 3.059 metros de linha tronco (DN 150) e 11.622 metros no trecho urbano com DN 150, DN 100, DN 75 E DN 50.

\subsubsection{Sistema de Esgotamento Sanitário}

Os sistemas de esgotamento sanitários implantados nas localidades da pesquisa compõem-se basicamente de rede coletora condominial, rede coletora convencional e estação de tratamento por Tanques Imhoff, seguidos 
por "Wetland", ou, quando há disponibilidade de área, por Lagoa de Estabilização. As residências situadas em ponto distante ou com cota topográfica inferior à da rede geral têm soluçōes individuais com fossa séptica seguida de infiltração no solo.

As redes condominiais são instaladas preferencialmente no fundo das casas, próximo ao local de implantação do módulo sanitário. As definições do traçado foram acordadas nos encontros com as equipes de educação ambiental, quando também foram escolhidos os síndicos das quadras. A seguir são apresentados os principais dados dos sistemas de esgotamento dessas localidades:

\subsubsection{Vila Cardoso}

Rede Coletora: Rede condominial com extensão de 4.015 metros e DN 150, e rede básica com extensão de 1.795 metros e DN 150 .

Estação de Tratamento: Sete Tanques Imhoff, cada um com 10 metros de comprimento, 3,5 metros de largura e 3,5 metros de profundidade e um conjunto de 3 áreas de "Wetland", cada uma com 15 metros de comprimento, 10 metros e largura e $90 \mathrm{~cm}$ de profundidade (CERB 1999a).

Corpo Receptor: Talvegue seco do rio Itapicurú Mirim (bacia hidrográfica do rio Itapicurú Açu).

A figura 12, a seguir, mostra a estação de tratamento de Vila Cardoso e uma plantação de milho irrigado com o efluente. 


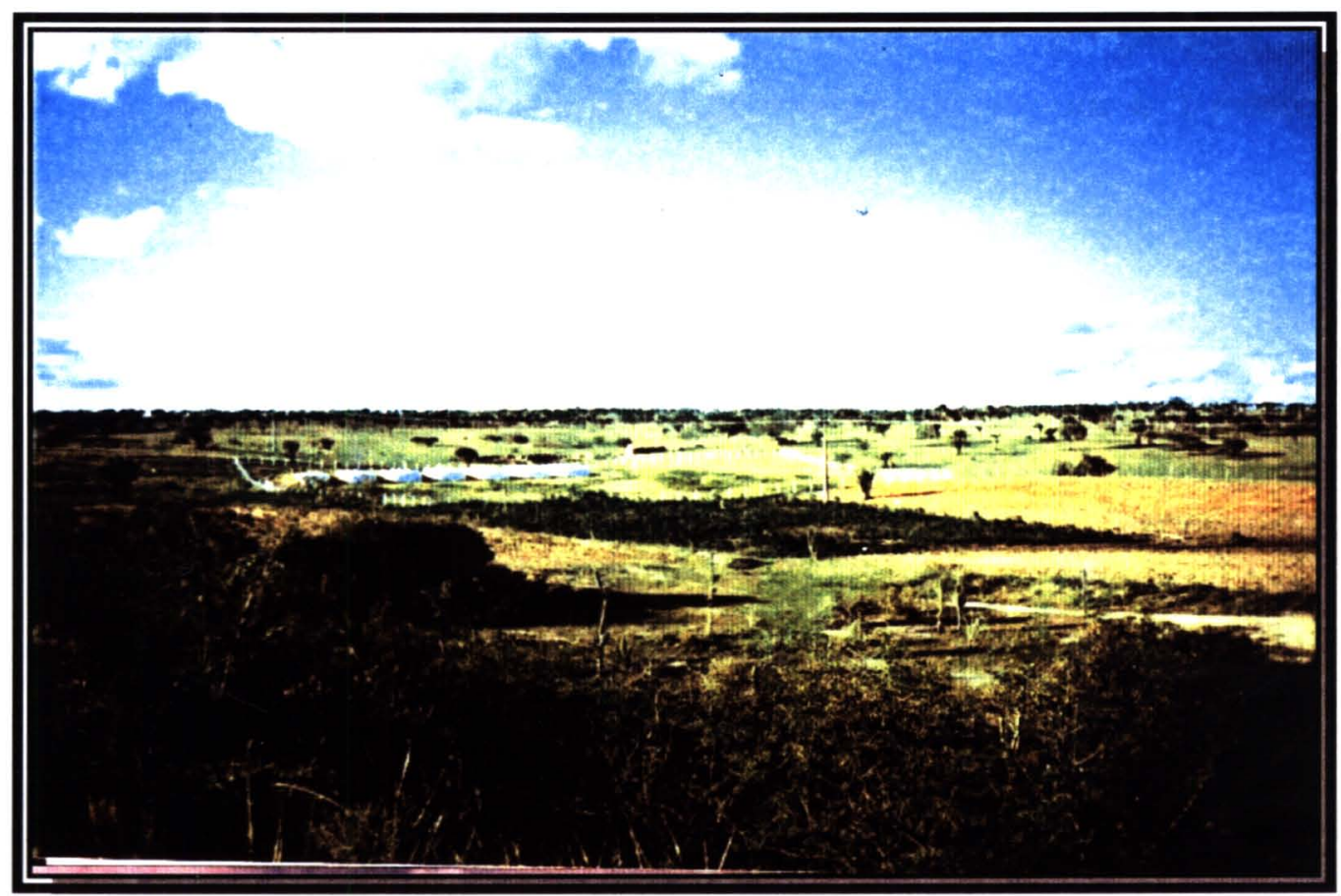

Figura 12 Tanque Imhoff e wetland e campo de irrigação.

\subsubsection{Gameleira}

Rede Coletora: Rede condominial com extensão de 5.199 metros e DN 150, e rede básica com extensão de 2.899 metros e DN 150.

Estação de Tratamento: Cinco Tanques Imhoff, cada um com 10 metros de comprimento, 3,5 metros de largura e 3,5 metros de profundidade e um conjunto de 3 áreas de "Wetland", cada uma com 20 metros de comprimento, 10 metros e largura e $90 \mathrm{~cm}$ de profundidade.

Corpo Receptor: Talvegue seco da bacia do rio Jacurici (bacia hidrográfica do rio Itapicurú Açu) (CERB 2000a).

\subsubsection{Jacunã}

Rede Coletora: Rede condominial com extensão de 1.551 metros e DN 150, e a rede básica com extensão de 790 metros e DN 150. 
Estação de Tratamento: Duas lagoas de Estabilização em paralelo, cada uma com 60 metros de comprimento, 30 metros de largura e 1 metro de profundidade útil.

Corpo Receptor: Talvegue seco da bacia do rio Jacurici (bacia hidrográfica do rio Itapicurú Açu) (CERB 2000b).

A figura 13 mostra a Lagoa de Estabilização de Jacunã.

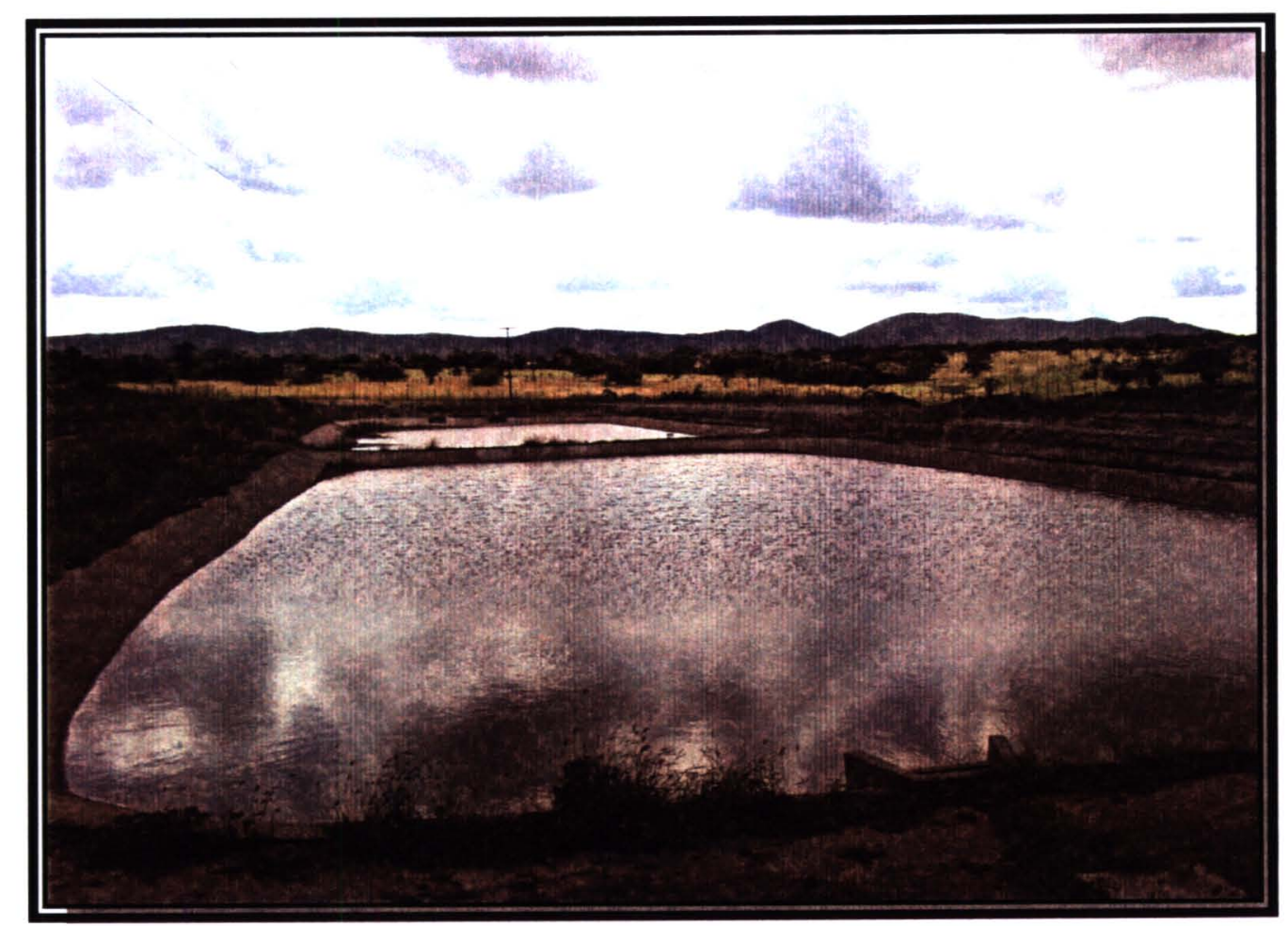

Figura 13 Lagoa de Estabilização de Jacunã.

\subsubsection{Piaus}

O sistema de esgotamento implantado consiste em um conjunto de soluções coletivas para grupos de casas, com fossa séptica, filtro anaeróbio e "Wetland" distantes do espelho d'água do açude para que este não receba efluentes sanitários, ainda que tratados (CERB 1999b). 


\subsubsection{Taquari}

Semelhante à situação de Piaus, o sistema consiste predominantemente de Fossas Sépticas e Sumidouro (ou Vala de Infiltração) para uma residência ou um conjunto de até 3 residências (CERB 1999b).

\subsubsection{Lajinha}

Rede Coletora: Rede condominial com extensão de 1.770 metros e DN 150, e rede básica com extensão de 843 metros e DN 150.

Estação de Tratamento: Cinco Tanques Imhoff cada um com 10 metros de comprimento, 3,5 metros de largura e 3,5 metros de profundidade e um conjunto de 3 áreas de "wetland", cada uma com 14 metros de comprimento, 5 metros e largura e $90 \mathrm{~cm}$ de profundidade (CERB 1998e).

Corpo Receptor: rio do Aipim (bacia hidrográfica do rio Itapicurú Açu).

A figura 14 mostra a estação de tratamento de esgoto de Lajinha. 


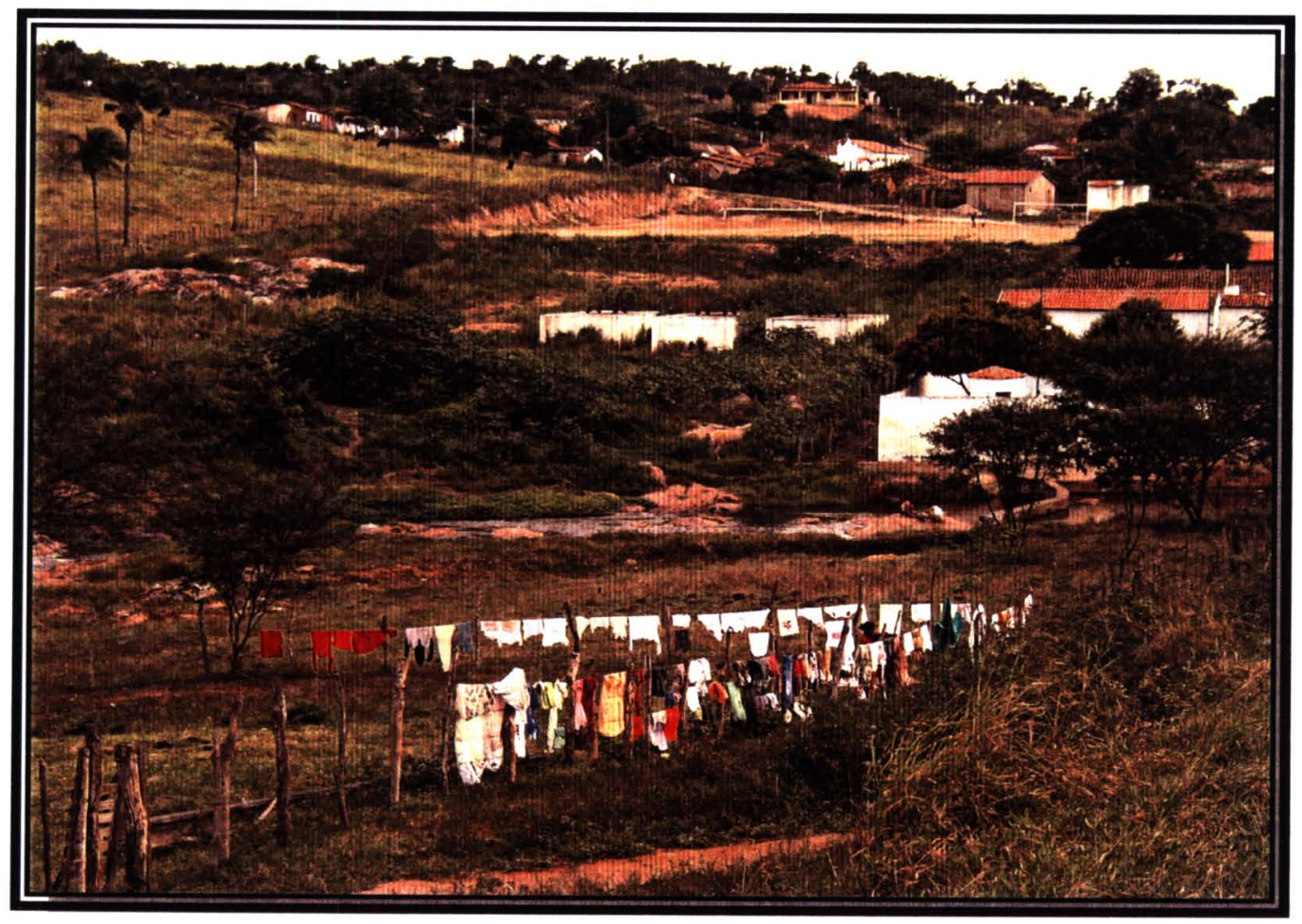

Figura 14 Estação de Tratamento de Esgoto de Lajinha, rio do Aipim e vista parcial da localidade.

A tabela 8 apresenta as populações das localidades previstas nos projetos de abastecimento de água e de esgotamento sanitário para início e final de plano, considerando a taxa de crescimento de $3,53 \%$ ao ano, o que corresponde à duplicação da população após 20 anos.

Tabela 8 População das localidades da pesquisa previstas pelos projetos de abastecimento de água e de esgotamento sanitário para início e final de plano.

\begin{tabular}{c|c|c}
\hline \multirow{2}{*}{ Localidade } & \multicolumn{2}{|c}{ População } \\
\cline { 2 - 3 } & $\mathbf{( 1 9 9 9 )}$ & $\mathbf{( 2 0 1 9 )}$ \\
\hline Vila Cardoso & 1.350 & 2.700 \\
\hline Gameleira & 2.755 & 5.510 \\
\hline Jacunã & 1.220 & 2.440 \\
\hline Piaus & 1.780 & 3.560 \\
\hline Taquari & 460 & 920 \\
\hline Lajinha & 610 & 1.220 \\
\hline \multirow{2}{*}{ Total } & 8.175 & 16.350
\end{tabular}


Os períodos de implantação dos sistemas de saneamento são apresentados na tabela 9, e nas tabelas 10, 11, 12, 13 e 14 a seguir, tem-se respectivamente, os períodos e custos de implantação dos sistemas, de água e de esgoto das localidades do projeto. Os custos compõem-se do valor do projeto, construção do sistema e das melhorias sanitárias. Foi acrescido um custo de $10 \%$ sobre o valor do projeto e da construção relativos ao serviço de acompanhamento e fiscalização feito pela CERB. No caso específico da localidade de Lajinha, para efeito de cálculo do custo per capita, como a construção englobou outros pequenos aglomerados dispersos, a população utilizada (1.642 habitantes) refere-se a todas as comunidades e não apenas à de Lajinha.

Tabela 9 Período de implantação dos SAA e SES das localidades da pesquisa.

\begin{tabular}{c|c|c|c|c|c|c}
\hline \multirow{2}{*}{ Itens } & \multicolumn{6}{c|}{ Localidades } \\
\cline { 2 - 6 } & $\begin{array}{c}\text { Vila } \\
\text { Cardoso }\end{array}$ & Gameleira & Jacunã & Piaus & Taquari & Lajinha \\
\hline $\begin{array}{c}\text { Período de } \\
\text { Implantação }\end{array}$ & OUT/99 & JAN/02 & JAN/02 & JUL/00 & JUL/00 & JAN/01
\end{tabular}

Fonte: CERB

Tabela 10 Custo em Reais dos sistemas de abastecimento de água das localidades da pesquisa.

\begin{tabular}{|c|c|c|c|c|c}
\hline \multirow{2}{*}{ Itens } & \multicolumn{5}{|c}{ Localidades } \\
\cline { 2 - 6 } & Vila Cardoso & Gameleira/Jacunã & Piaus/Taquari & Lajinha & TOTAL \\
\hline Projeto & $18.981,01$ & $91.410,98$ & $53.093,74$ & $27.282,01$ & $190.767,74$ \\
\hline Poço & $20.000,00$ & $40.000,00$ & - & $20.000,00$ & $80.000,00$ \\
\hline Construção & $189.810,13$ & $914.109,82$ & $530.937,35$ & $272.820,12$ & $1.907 .677,42$ \\
\hline Fisc/Admin & $18.981,01$ & $91.410,98$ & $53.093,74$ & $27.282,01$ & $190.767,74$ \\
\hline $\begin{array}{c}\text { Total } \\
\text { Fonte (CERB 1998a; 1998b; 1998c; 1998d) }\end{array}$ & $\mathbf{2 4 7 . 7 7 2 , 1 6}$ & $\mathbf{1 . 1 3 6 . 9 3 1 , 7 8}$ & $\mathbf{6 3 7 . 1 2 4 , 8 2}$ & $\mathbf{3 4 7 . 3 8 4 , 1 4}$ & $\mathbf{2 . 3 6 9 . 2 1 2 , 9 0}$
\end{tabular}

Tabela 11 População de final de plano e custo per capita dos sistemas de abastecimento de água das localidades da pesquisa.

\begin{tabular}{c|c|c|c|c|c}
\hline \multirow{2}{*}{ Itens } & \multicolumn{5}{|c}{ Localidades } \\
\cline { 2 - 6 } & $\begin{array}{c}\text { Vila } \\
\text { Cardoso }\end{array}$ & Gameleira/Jacunã & Piaus/Taquari & Lajinha & TOTAL \\
\hline $\begin{array}{c}\text { População } \\
\text { (hab.) }\end{array}$ & 3.074 & 7.950 & 4.458 & 1.642 & 17.124 \\
\hline $\begin{array}{c}\text { Custo per } \\
\text { capita (R\$/hab.) }\end{array}$ & $\mathbf{8 1}$ & $\mathbf{1 4 3}$ & $\mathbf{1 4 3}$ & $\mathbf{2 1 2}$ & $\mathbf{1 3 8}$ \\
Fonte & & & &
\end{tabular}


Tabela 12 Custo em Reais dos sistemas de esgotamento sanitário das localidades da pesquisa.

\begin{tabular}{c|c|c|c|c|c|c}
\hline \multirow{2}{*}{ Itens } & \multicolumn{7}{c}{ Localidades } \\
\cline { 2 - 7 } & $\begin{array}{c}\text { Vila } \\
\text { Cardoso }\end{array}$ & Gameleira & Jacunã & $\begin{array}{c}\text { Piaus/ } \\
\text { Taquari }\end{array}$ & Lajinha & Total \\
\hline Projeto & $35.141,98$ & $35.474,04$ & $16.418,09$ & $29.799,87$ & $19.660,67$ & $136.494,66$ \\
\hline Construção & $351.419,82$ & $354.740,43$ & $164.180,93$ & $297.998,72$ & $196.606,67$ & $1.364 .946,57$ \\
\hline Fisc/Admin & $35.141,98$ & $35.474,04$ & $16.418,09$ & $29.799,87$ & $19.660,67$ & $136.494,66$ \\
\hline $\begin{array}{c}\text { Total } \\
\text { Fonte (CERB 1998; 1999a; 1999b; 2000a; 20006) }\end{array}$ & $\mathbf{4 2 1 . 7 0 3 , 7 8}$ & $\mathbf{4 2 5 . 6 8 8 , 5 2}$ & $\mathbf{1 9 7 . 0 1 7 , 1 2}$ & $\mathbf{3 5 7 . 5 9 8 , 4 6}$ & $\mathbf{2 3 5 . 9 2 8 , 0 0}$ & $\mathbf{1 . 6 3 7 . 9 3 5 , 8 8}$ \\
\end{tabular}

Tabela 13 População de final de plano e custo per capita dos sistemas de esgotamento sanitário das localidades da pesquisa.

\begin{tabular}{c|c|c|c|c|c|c}
\hline \multirow{2}{*}{ Itens } & \multicolumn{6}{|c}{ Localidades } \\
\cline { 2 - 7 } & $\begin{array}{c}\text { Vila } \\
\text { Cardoso }\end{array}$ & Gameleira & Jacunã & Piaus/Taquari & Lajinha & Total \\
\hline $\begin{array}{c}\text { População } \\
\text { (hab.) }\end{array}$ & 3.074 & 5.510 & 2.440 & 4.458 & 1.642 & 17.124 \\
\hline $\begin{array}{c}\text { Custo per } \\
\text { capita (R\$/hab.) } \\
\text { Fonte (CERB 1998; 1999a; 1999b; 2000a; 2000b) }\end{array}$ & $\mathbf{1 3 7}$ & $\mathbf{7 7}$ & $\mathbf{8 1}$ & $\mathbf{8 0}$ & $\mathbf{1 4 4}$ & $\mathbf{9 6}$ \\
\hline
\end{tabular}

Tabela 14 População de final de plano e custo per capita dos sistemas abastecimento de água e de esgotamento sanitário das localidades da pesquisa.

\begin{tabular}{c|c|c|c|c|c}
\hline \multirow{2}{*}{ Itens } & \multicolumn{5}{|c}{ Localidades } \\
\cline { 2 - 6 } & $\begin{array}{c}\text { Vila } \\
\text { Cardoso }\end{array}$ & $\begin{array}{c}\text { Gameleira/ } \\
\text { Jacunã }\end{array}$ & $\begin{array}{c}\text { Piaus/ } \\
\text { Taquari }\end{array}$ & Lajinha & Total \\
\hline $\begin{array}{c}\text { População } \\
\text { (hab.) }\end{array}$ & 3.074 & 7.950 & 4.458 & 1.642 & 17.124 \\
\hline $\begin{array}{c}\text { Custo total } \\
\text { (R\$) }\end{array}$ & $669.475,94$ & $1.759 .637,42$ & $994.723,28$ & $583.312,15$ & $4.007 .148,79$ \\
\hline $\begin{array}{c}\text { Custo per capita } \\
\text { (R\$/hab.) }\end{array}$ & 218 & 143 & 223 & 355 & 234 \\
Fonte (CERB 1998a; 1998b; 1998c; 1998d; 1998e; 1999a; 1999b; 2000a; 2000b)
\end{tabular}

\subsubsection{Modelo de Operação dos Sistemas de Saneamento pela Central}

A Tabela 15 a seguir apresenta para cada localidade da pesquisa o número de ligações à rede de abastecimento de água e o número correspondente de casas da localidade. 
Tabela 15 Número de ligações de abastecimento de água e percentual de atendimento por localidade.

\begin{tabular}{l|c|c|c|c|c|c|c}
\hline \multirow{2}{*}{ Itens } & \multicolumn{7}{c}{ Localidades } \\
\cline { 2 - 8 } & V. Cardoso & Gameleira & Jacunã & Piaus & Taquari & Lajinha & Total \\
\hline N. de ligações & 382 & 526 & 233 & 255 & 122 & 200 & 1.718 \\
\hline $\begin{array}{l}\text { Atendimento (\%) } \\
\text { Fonte: Central II }\end{array}$ & 98,7 & 100,0 & 100,0 & 96,5 & 100,0 & 97,0 & 98,8
\end{tabular}

O valor da tarifa de água e esgoto de cada localidade é calculado para cobrir as despesas da energia elétrica dos sistemas de recalque, o salário do operador de cada localidade e a taxa de manutenção para a Central II. Os valores das tarifas para o consumo mínimo de $10 \mathrm{~m}^{3}$ são apresentados na Tabela 16 a seguir.

Tabela 16 Tarifa de água e esgoto em Reais para o consumo mínimo de $10 \mathrm{~m}^{3}$ das localidades do sistema Central II.

\begin{tabular}{c|c|c|c|c|c|c}
\hline \multirow{2}{*}{ Entidades } & \multicolumn{7}{|c}{ Localidades } \\
\cline { 2 - 7 } & V. Cardoso & Gameleira & Jacunã & Piaus & Taquari & Lajinha \\
\hline Associação & 3,00 & 3,00 & 3,00 & 4,65 & 4,65 & 2,30 \\
\hline Central & 3,85 & 3,85 & 3,85 & 3,85 & 3,85 & 3,85 \\
\hline Total & $\mathbf{6 , 8 5}$ & $\mathbf{6 , 8 5}$ & $\mathbf{6 , 8 5}$ & $\mathbf{8 , 5 0}$ & $\mathbf{8 , 5 0}$ & $\mathbf{6 , 1 5}$
\end{tabular}

Segundo o relatório da Central II, 75\% das contas são pagas até o dia do vencimento, $20 \%$ pagas com multa no período subsequente, $4 \%$ pagas ao receber $\mathrm{o}$ aviso de corte e $1 \%$ efetivamente cortadas, sendo estas religadas dentro de 2 meses em média.

O controle básico da qualidade da água de abastecimento é feito por medição diária do cloro residual em campo pelo método colorimétrico, quando o operador efetua os ajustes através do clorador. Semestralmente, são enviadas amostras de água para laboratório onde são feitas análises de turbidez, pH e coliformes. Segundo a Central II, os resultados da análise de laboratório apresentam valores em acordo com os limites estabelecidos na Portaria 1.469 de 2000 do Ministério da Saúde (MS 2001). 
A qualidade dos efluentes das estações de tratamento tem sido monitorada basicamente pelos parâmetros de DBO (Demanda Bioquímica de Oxigênio) e de Coliformes Totais e Fecais. Os efluentes são monitorados com uma frequência anual. A tabela 17 a seguir apresenta os resultados de uma campanha de amostragem feita para a localidade de Vila Cardoso cuja cópia encontra-se no Anexo A.

Tabela 17 Valores de DBO, DQO, sólidos totais, sólidos voláteis e coliformes fecais da Estação de Tratamento de Esgoto de Vila Cardoso.

\begin{tabular}{c|c|c|c}
\hline \multirow{2}{*}{ Parâmetros } & \multicolumn{3}{|c}{ Local de coleta } \\
\cline { 2 - 4 } & Entrada & Saída do tanque & Saída da wetland \\
\hline DBO $(\mathrm{mg} / \mathrm{l})$ & 780 & 320 & 80 \\
\hline DQO $(\mathrm{mg} / \mathrm{l})$ & 1.500 & 500 & 250 \\
\hline Sólidos totais $(\mathrm{mg} / \mathrm{l})$ & 2.260 & 1.818 & 1.462 \\
\hline Sólidos voláteis $(\mathrm{mg} / \mathrm{l})$ & 1.196 & 1.130 & 654 \\
\hline C. total $(\mathrm{NMP} / 100 \mathrm{ml})$ & $10^{6}$ & $10^{5}$ & $10^{3}$ \\
\hline C. fecal $(\mathrm{NMP} / 100 \mathrm{ml})$ & $10^{6}$ & $10^{5}$ & $10^{3}$
\end{tabular}
Fonte: Central II

A frequência de interrupção e os principais problemas registrados pela equipe de operação desde o início de funcionamento são listados nas tabelas 18 e 19 a seguir:

Tabela 18 Frequência de interrupções nos sistemas de água das localidades do sistema Central II, desde início de operação até o mês julho de 2002.

\begin{tabular}{|c|c|c|c|c|c|c|}
\hline \multirow{2}{*}{$\begin{array}{c}\text { Período } \\
\text { da } \\
\text { parada } \\
\text { (hora) }\end{array}$} & \multicolumn{6}{|c|}{ Localidades } \\
\hline & $\begin{array}{l}\text { V. Cardoso } \\
\text { (33 meses) }\end{array}$ & $\begin{array}{l}\text { Gameleira } \\
\text { (6 meses) }\end{array}$ & $\begin{array}{c}\text { Jacunã } \\
\text { (6 meses) }\end{array}$ & $\begin{array}{c}\text { Piaus } \\
\text { (24 meses) }\end{array}$ & $\begin{array}{c}\text { Taquari } \\
\text { (24 meses) }\end{array}$ & $\begin{array}{c}\text { Lajinha } \\
\text { (18 meses) }\end{array}$ \\
\hline$<6$ horas & - & - & - & - & - & - \\
\hline $\begin{array}{l}\text { Entre } 6 \text { e } \\
12 \text { horas }\end{array}$ & 1 & - & - & - & - & 3 \\
\hline $\begin{array}{c}\text { Entre } 12 \mathrm{e} \\
24 \text { horas }\end{array}$ & 2 & 1 & - & 1 & 1 & 1 \\
\hline $\begin{array}{c}\text { Superior a } \\
24 \text { horas } \\
\text { Fonte: Central }\end{array}$ & - & - & - & - & 3 & 1 \\
\hline
\end{tabular}


Tabela 19 Principais problemas relatados pela equipe de manutenção da Central II.

\begin{tabular}{|l|c|}
\hline \multicolumn{1}{|c|}{ Problema } & Frequência \\
\hline Roubos de quadro de comando & 1 \\
\hline Vandalismo (isolador da Coelba) & 1 \\
\hline Violação de registro & 6 \\
\hline Ligação clandestina & 3 \\
\hline Vazamentos iniciais & 2 meses iniciais \\
\hline Fonte: Central II
\end{tabular}

Nas figuras 15 a 20 a seguir são apresentados os croquis das localidades da pesquisa, com as respectivas redes básicas de esgotamento sanitário. 


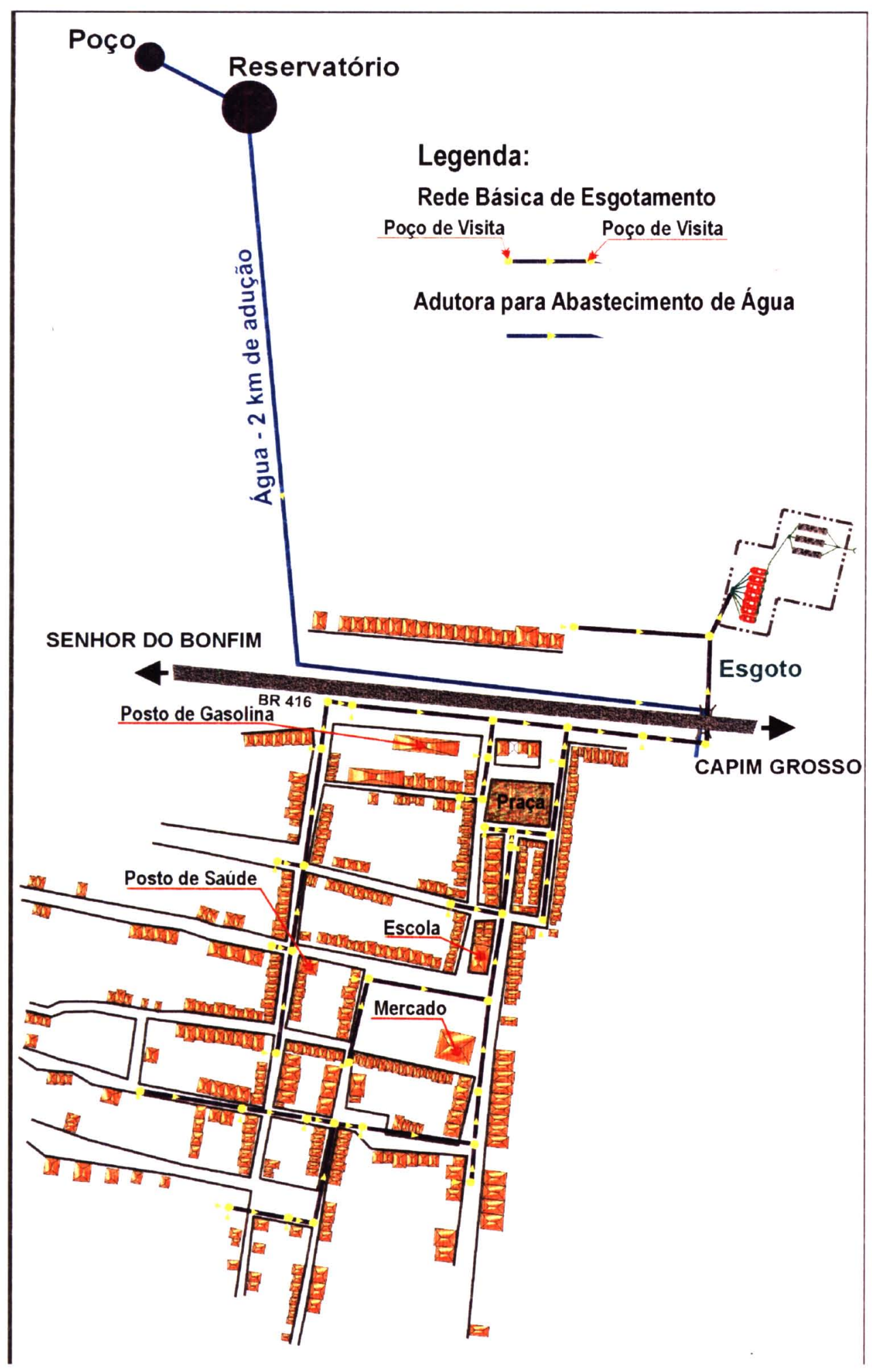

Figura 15 Croqui da localidade de Vila Cardoso com rede básica de abastecimento de água e de esgotamento sanitário. 


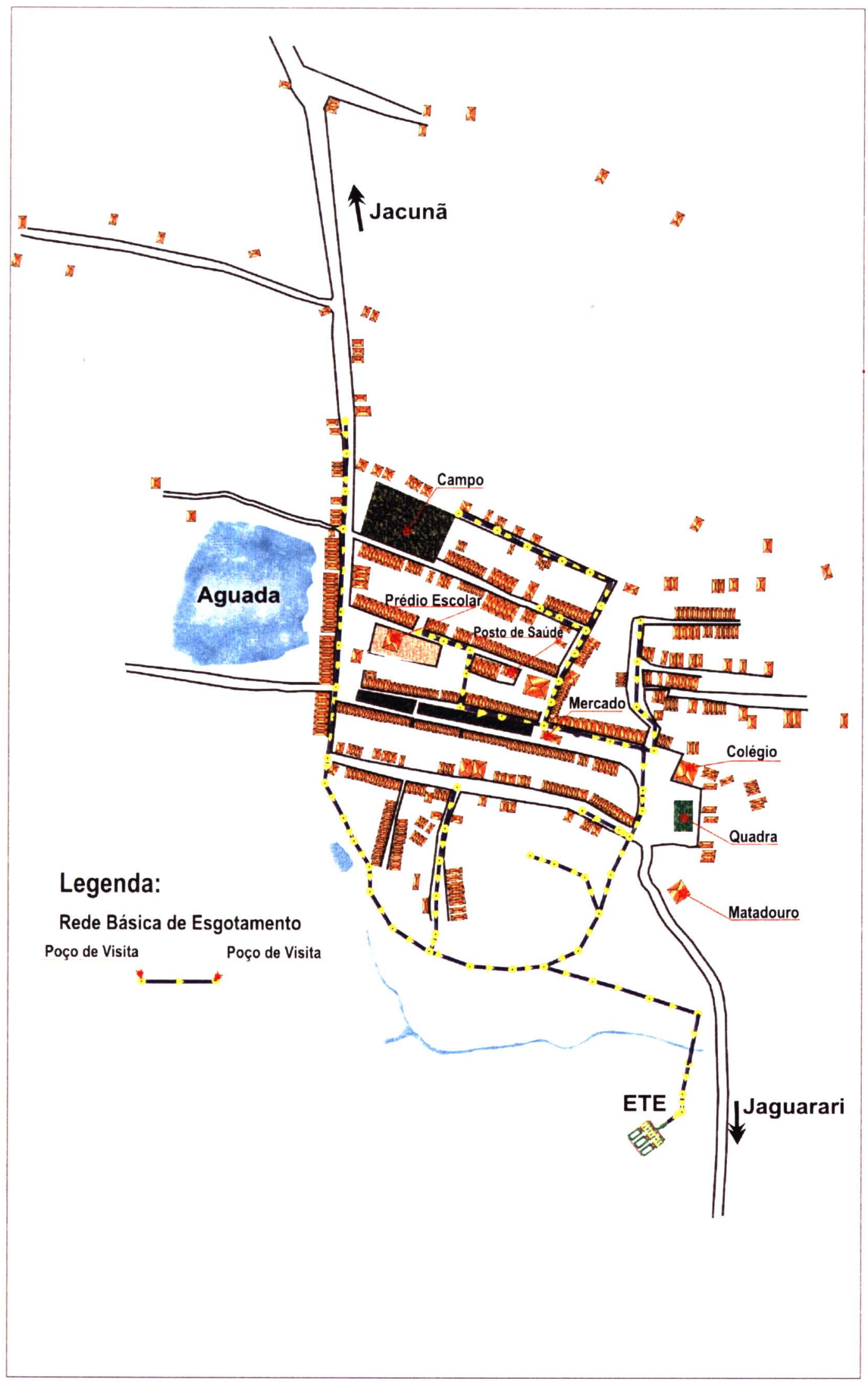

Figura 16 Croqui da localidade de Gameleira com rede básica de esgotamento sanitário. 


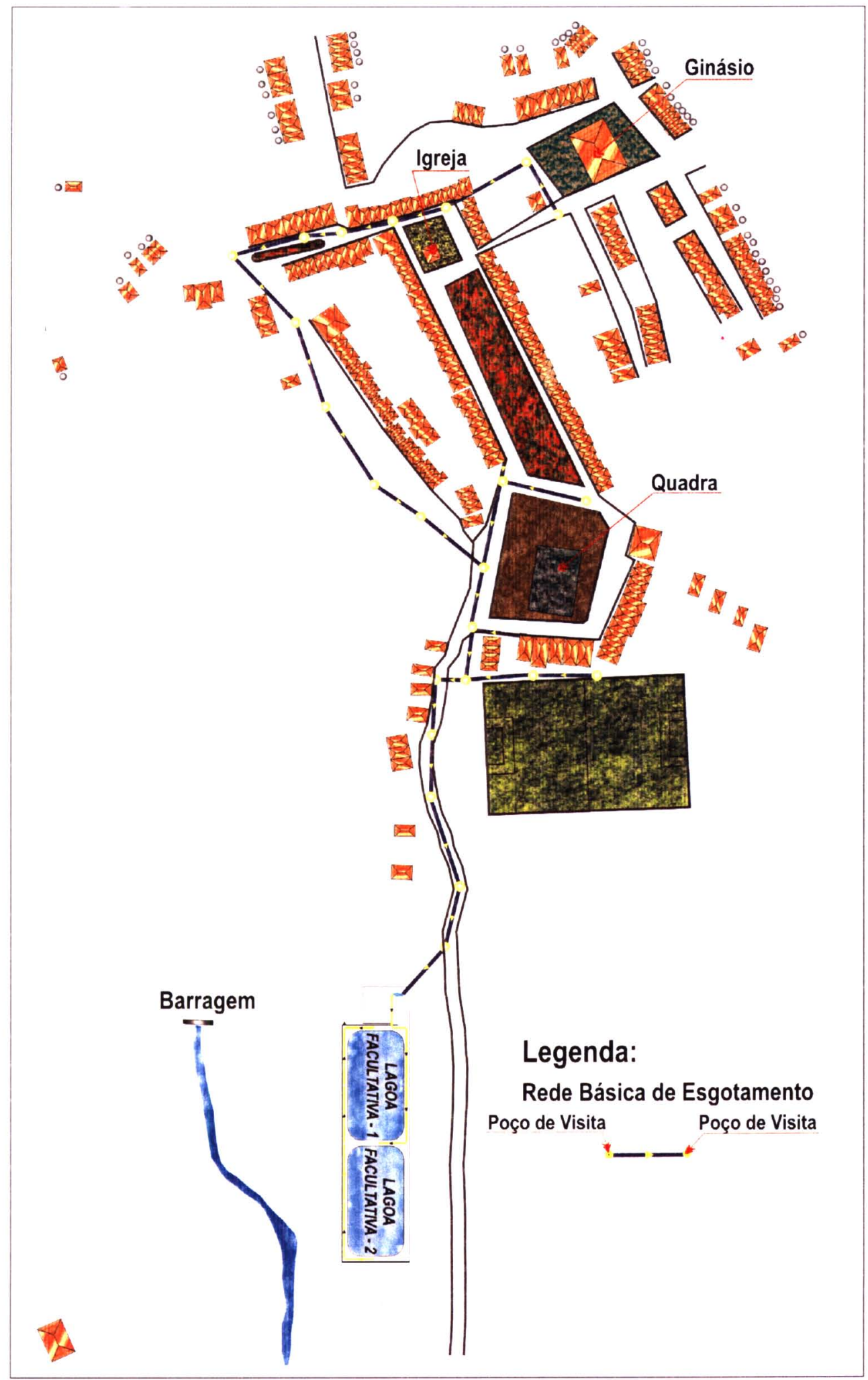

Figura 17 Croqui da localidade de Jacunã com rede básica de esgotamento sanitário. 


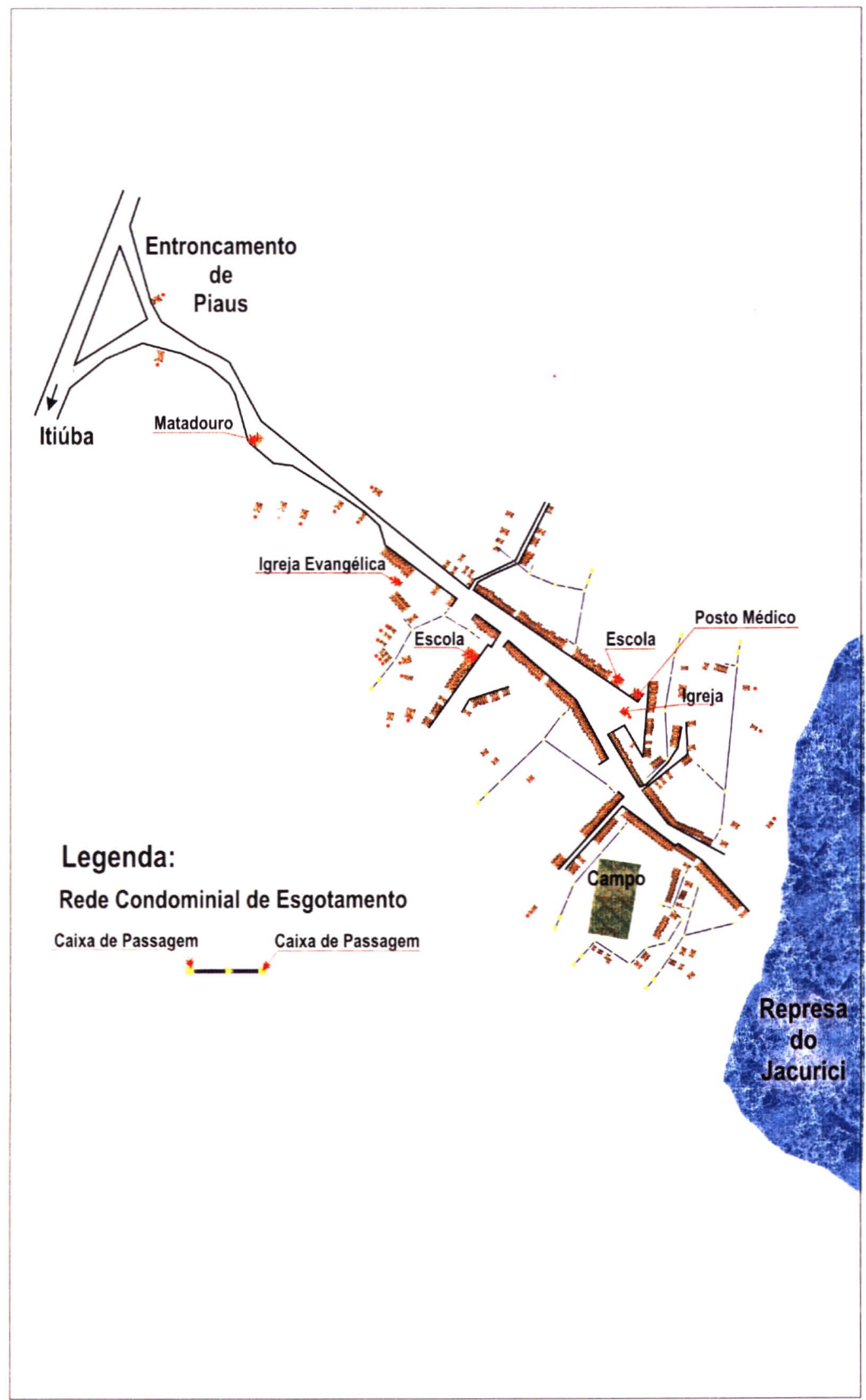

Figura 18 Croqui da localidade de Piaus com rede básica de esgotamento sanitário. 


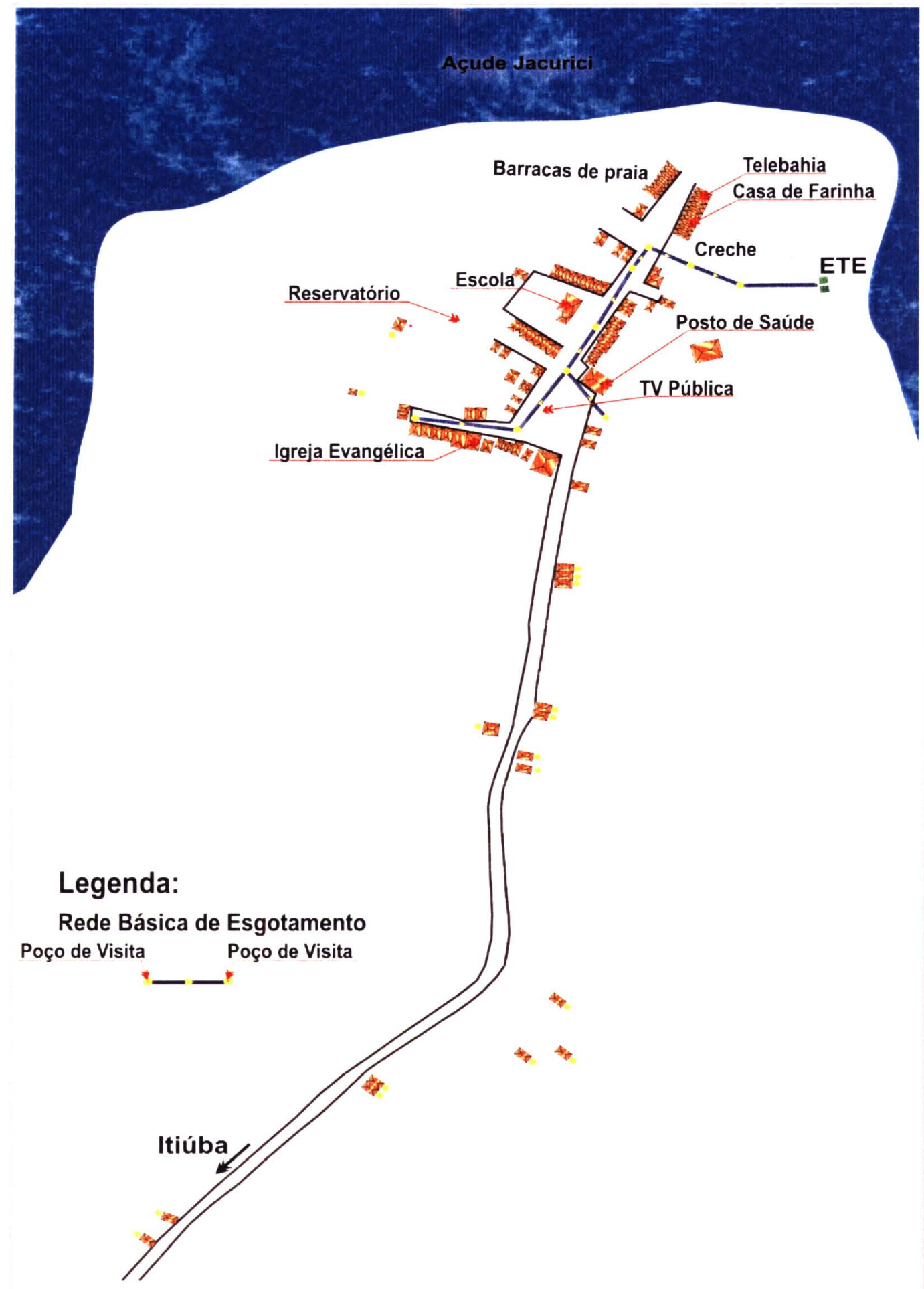

Figura 19 Croqui da localidade de Taquari com rede básica de esgotamento sanitário. 


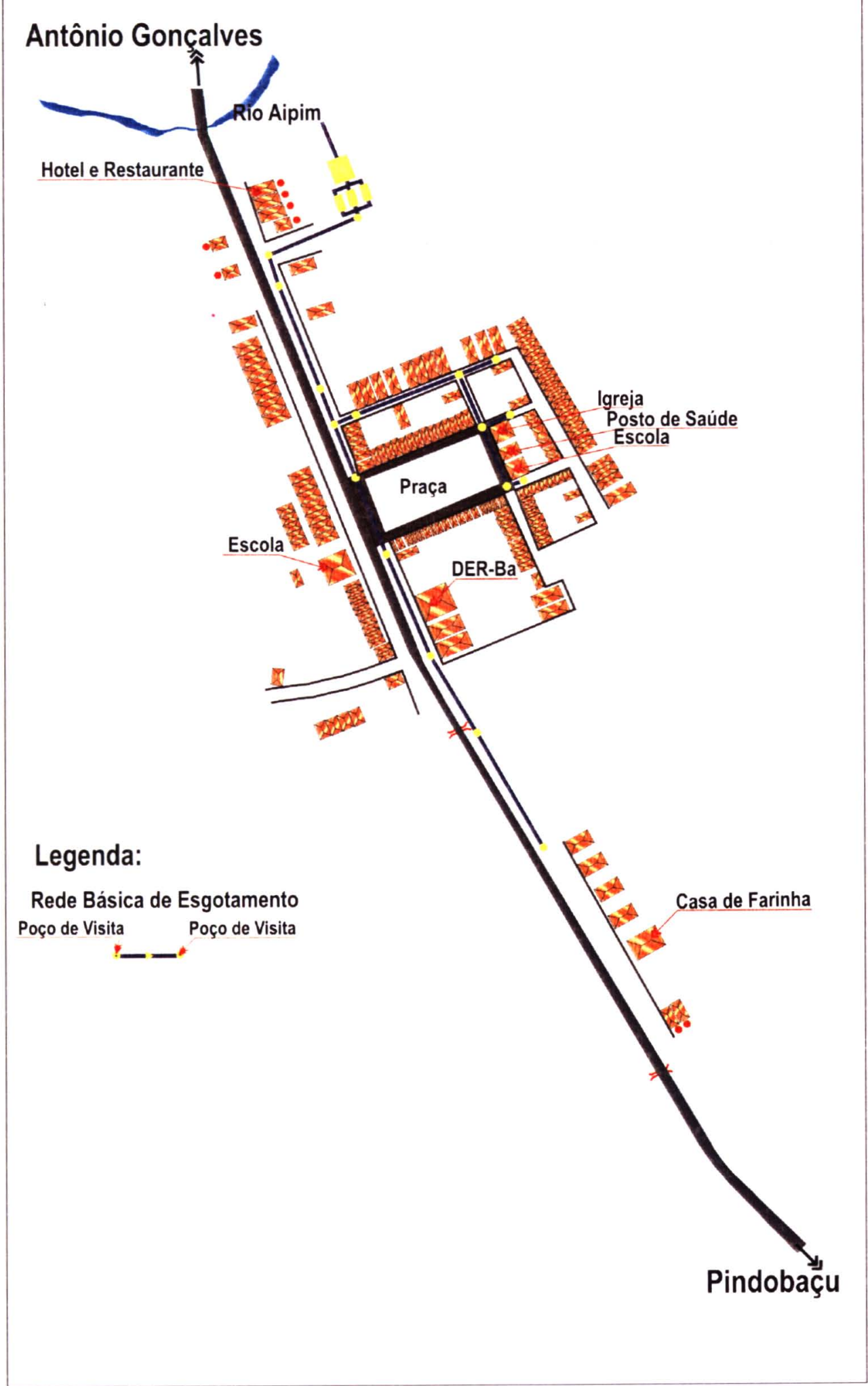

Figura 20 Croqui da localidade de Lajinha com rede básica de esgotamento sanitário. 


\section{$5 \quad$ RESULTADOS E DISCUSSÃO}

A seguir, são apresentados os resultados dos questionários aplicados em uma amostra da população das localidades da pesquisa depois da implantação do sistema de saneamento.

A tabela 20 a seguir apresenta o consumo médio per capita antes e depois da implantação do saneamento, baseado nas informações do questionário e nos registros de consumos da Central II.

Tabela 20 Consumo médio de água per capita antes e depois da implantação do SAA e SES, segundo localidades do semi-árido baiano, 2002.

\begin{tabular}{c|c|c}
\hline \multirow{2}{*}{ Localidade } & \multicolumn{2}{|c}{ Consumo médio de água per capita (L/hab.dia) } \\
\cline { 2 - 3 } & Antes & $\begin{array}{c}\text { Depois * } \\
\text { média }\end{array}$ \\
\hline Vila Cardoso & $23,4(16,7)$ & 62 \\
Gameleira & $23,1(15,1)$ & 72 \\
Jacunã & $21,4(8,6)$ & 73 \\
Piaus & $25,2(13,9)$ & 63 \\
Taquari & $\mathrm{NI}$ & 74 \\
Lajinha & $\mathrm{NI}$ & 70 \\
\hline Valor médio & $\mathbf{2 2 , 6 ( 1 3 , 9 )}$ & $\mathbf{7 0}$ \\
NI =Não informado & &
\end{tabular}

Os valores do consumo de água per capita, do preço do metro cúbico da água e do desembolso mensal que as famílias tinham antes da implantação do SAA e do SES foram calculados a partir das diversas unidades de volume citadas pela população (lata, carro, pipa, tonel. etc) e transformados para a unidade métrica. As variações ocorridas são estatisticamente significantes ao nível de $5 \%$.

O consumo per capita médio encontrado foi de 22,6L/hab.dia com desvio padrão de 13,9L/hab.dia, havendo uma variação no consumo médio entre as localidades de 21,0 a 25,2L/hab.dia. A quantidade de 22,6L/hab.dia equivale aproximadamente ao volume de um pouco mais de uma lata de 18 litros e representa cerca de um quarto da quantidade prevista pela Norma Brasileira 
de 80L/hab.dia (ABNT 1994b). Valores de 27L/hab.dia foram encontrados numa pesquisa em áreas da periferia de Salvador, onde não havia água potável domiciliar, (MORAES 1997). Esses valores são limitados pela própria escassez da água e/ou pela dificuldade de transporte do manancial até a residência, e que atendem apenas aos usos de bebida, cozimento e limpeza sendo esta última feita de forma simplificada e com potencial de contaminação e de veiculação de doenças.

No momento atual, o consumo médio das localidades varia entre 62 e 74L/hab.dia (média de 69 L/hab.dia), correspondendo a $85 \%$ do previsto pela referida norma e superior a 60Lhab/dia encontrado por MORAES (1997), numa área da periferia de Salvador, após implantação de melhorias no saneamento local. Já em um estudo realizado na cidade de São Paulo (ROCHA e BARRETO 1999) verificou-se que o consumo de água per capita de uma habitação unifamiliar de um conjunto de apartamento era de 109L/hab.dia, sendo o consumo de água do chuveiro correspondente a $55 \%$ desta quantidade, o da pia de cozinha a $18 \%$. Os consumo do vaso sanitário e do lavatório correspondiam a apenas $5 \%$ e $8 \%$ respectivamente.

A diferença entre o consumo médio per capita da população das localidades estudadas em comparação com o estudo na cidade de São Paulo pode ser atribuída à diferença de hábitos entre estas populações e especialmente à escassez histórica da água que condiciona as pessoas a um hábito de economia da água em todas as formas de uso.

Os entrevistados das localidades de Lajinha e de Taquari declararam não se lembrar da quantidade de água que carregavam para casa antes dos sistemas de saneamento. Na localidade de Piaus apenas 2 entrevistados lembravam dessa informação.

As variações do consumo médio per capita em diferentes períodos do ano podem ser vistas na tabela 21 a seguir, na qual são apresentados os 
consumos médios de água per capita da localidade de Vila Cardoso, em 3 períodos do ano (fevereiro, maio e novembro), utilizando o registro de consumo das contas de água dessa localidade, fornecido pela Central II.

Tabela 21 Variação sazonal do consumo médio per capita em Vila Cardoso, 2001.

\begin{tabular}{c|c}
\hline Período & $\begin{array}{c}\text { Consumo médio per capita } \\
\text { Média (DP) }\end{array}$ \\
\hline FEV/01 & $60(16)$ \\
MAl/01 & $65(10)$ \\
NOV/01 & $83(15)$ \\
\hline Médio & $69(111)$
\end{tabular}

Dentre os três períodos analisados, o menor consumo per capita (60L/hab.dia) ocorreu no mês de Fevereiro (período de chuva), representando $87 \%$ do consumo médio de $69 \mathrm{~L} /$ hab.dia. No mês de novembro, (período de seca) o consumo de 83L/hab.dia representa um acréscimo de $20 \%$ do consumo médio. Embora este acréscimo de consumo refira-se ao consumo mensal e o acréscimo de vazão recomendado pela Norma Brasileira (ABNT 1994b) refira-se ao dia de maior consumo $\left(k_{2}\right)$, poder-se-ia traçar um paralelo entre esses dois acréscimos observando que ambos apresentam um valor de $20 \%$.

Os valores médios do metro cúbico de água vendida nas localidades da pesquisa antes da implantação do sistema de saneamento são apresentados na tabela 22, onde também se encontram os valores do metro cúbico de água fornecido pelos atuais sistemas de abastecimento de água. 
Tabela 22 Custo da água antes e depois da implantação do SAA e SES, segundo localidades do semi-árido baiano, 2002.

\begin{tabular}{c|c|c}
\hline \multirow{2}{*}{ Localidade } & \multicolumn{2}{|c}{$\begin{array}{c}\text { Custo da água }\left(\mathbf{R} \$ \mathbf{m}^{3}\right) \\
\text { Média (DP) }\end{array}$} \\
\cline { 2 - 3 } & Antes & Depois $^{\star}$ \\
\hline V. Cardoso & $11,90(6,70)$ & 0,69 \\
Gameleira & $18,80(18,90)$ & 0,69 \\
Jacunã & $14,80(9,10)$ & 0,69 \\
Piaus & $22,30(8,60)$ & 0,85 \\
Taquari & $1,00(0,00)$ & 0,85 \\
Lajinha & $\mathrm{NI}$ & 0,62 \\
\hline Médio & $\mathbf{1 6 , 0 0 ( 1 6 , 7 0 )}$ & \\
*Fonte: Central II & & \\
$\mathrm{NI}=$ Não Informado & &
\end{tabular}

O preço médio do metro cúbico de água comprada através de tonéis, latas, caminhão pipa, etc., encontrado na pesquisa foi de $\mathrm{R} \$ 16,60$. Com exceção de Taquari onde o preço era único de $1,00 \mathrm{R} \$ / \mathrm{m}^{3}$, nas outras localidades o preço variou entre 5,00 a $35,00 \mathrm{R} \$ / \mathrm{m}^{3}$, havendo valores extremos de $5,00 \mathrm{e}$ $100,00 \mathrm{R} \$ / \mathrm{m}^{3}$. Estes valores foram informados por 68 entrevistados $(40 \%)$ que disseram comprar a água. Os demais entrevistados $(60 \%)$ informaram serem eles próprios a coletar e a trazer a água para suas residências. Os valores das mudanças ocorridas são estatisticamente significantes ao nível de $5 \%$.

Na localidade de Lajinha, todos os moradores informaram não saber o preço da água nem o volume de água transportado para casa. Esta localidade, situada à margem do rio do Aipim, tem características diferentes das demais em relação ao transporte e custo da água. O rio do Aipim é perene e de fácil acesso, não demandando dos moradores o trabalho típico das demais localidades.

A tabela 23 a seguir apresenta o desembolso médio mensal das famílias para a compra da água antes do saneamento, considerando a dificuldade de acesso à água e o seu custo elevado. 
Tabela 23 Desembolso médio mensal para consumo de água por residência antes da implantação do SAA e SES, segundo localidades do semiárido baiano, 2002.

\begin{tabular}{c|c}
\hline Localidade & $\begin{array}{c}\text { Desembolso médio mensal (R\$) } \\
\text { Média (DP) }\end{array}$ \\
\hline Vila Cardoso & $12,60(6,30)$ \\
\hline Gameleira & $27,60(46,40)$ \\
\hline Jacunã & $22,40(23,30)$ \\
\hline Piaus & $14,90(15,00)$ \\
\hline Taquari & $5,10(1,70)$ \\
\hline Lajinha & $\mathrm{NI}$ \\
\hline Médio & $\mathbf{1 9 , 7 0 ( 3 3 , 1 0 )}$
\end{tabular}

O desembolso médio mensal para aquisição da água consumida anteriormente ao programa era de $\mathrm{R} \$ 19,70$, sendo as localidades de Gameleira e de Jacunã as que apresentaram os maiores valores ( $R$ \$ 27,60 e $\mathrm{R} \$ 22,40$ respectivamente). Havia variação do preço unitário em função da quantidade adquirida, do tipo de recipiente, da distância entre o manancial e a residência e do tipo de acesso aos tanques domiciliares. Relações pessoais entre o comprador e o fornecedor podiam também influenciar no preço de compra da água. As variações ocorridas são estatisticamente significantes ao nível de $5 \%$.

De acordo com observação local, atualmente os usuários procuram não ultrapassar o consumo mensal de $10 \mathrm{~m}^{3}$ com o objetivo de garantir o valor mínimo da conta de água situada entre $R \$ 6,15$ e $R \$ 8,00$. A diferença de desembolso para a condição anterior cujo custo mensal era de $\mathrm{R} \$ 15,70$ para um volume de água 2,3 vezes maior é de cerca de $R \$ 8,00$, que corresponde a $80 \%$ do valor de uma diária avulsa de trabalho na região $(R \$ 10,00)$. Este é um forte motivo de aceitação da população do sistema de abastecimento de água hidrometrado. O ganho monetário pode então ser revertido na compra de outros bens, como alimentos e/ou medicamentos.

A localização das fontes de água das localidades e as dificuldades para coleta e transporte demandavam um tempo diário da rotina de trabalho para 
execução dessa tarefa. A tabela 24 apresenta o tempo médio diário gasto pela população para obtenção da água.

Tabela 24 Tempo médio diário gasto por moradores para obtenção da água antes da implantação do SAA e SES, segundo localidades do semiárido baiano, 2002.

\begin{tabular}{c|c}
\hline Localidade & $\begin{array}{c}\text { Tempo (hora/dia) } \\
\text { Média (DP) }\end{array}$ \\
\hline Vila Cardoso & $1,3(0,8)$ \\
\hline Gameleira & $2,0(0,9)$ \\
\hline Jacunã & $1,2(0,6)$ \\
\hline Piaus & $1,7(1,0)$ \\
\hline Taquari & $0,7(0,5)$ \\
\hline Lajinha & $1,3(0,7)$ \\
\hline Médio & $\mathbf{1 , 3 ( 0 , 9 )}$
\end{tabular}

De acordo com as respostas dos moradores, o tempo médio diário utilizado para o transporte de água era de 1 hora e 20 minutos. Nas localidades de Gameleira e Piaus, os moradores consumiam mais tempo no transporte da água, sendo que nesta última, apesar de o açude situar-se próximo, as condições do relevo e o próprio tamanho da localidade não facilitavam a coleta direta da água no açude. As variações ocorridas são estatisticamente significantes ao nível de $5 \%$.

Segundo CAIRNCROSS (1993), em localidades onde o tempo gasto para transporte de água é superior a 10 minutos, há uma tendência de redução de consumo per capita para valores inferior a 20L/hab.dia. Considerando tal atividade como parte de uma jornada comum de trabalho, esta disponibilização da água no domicílio representa uma economia de tempo de $16 \%$ da jornada diária.

No questionário aplicado foi solicitada a informação de quais atividades o entrevistado passou a realizar no período anteriormente utilizado para coleta da água. A tabela 25 apresenta as atividades citadas em forma de prioridade uma vez que há a possibilidade de se optar por mais de uma atividade. 
Tabela 25. Priorização do tempo disponível pela população depois da implantação do SAA e SES, segundo atividade e localidades do semi-árido baiano, 2002.

\begin{tabular}{|c|c|c|c|c|c|c|c|}
\hline \multirow{2}{*}{ Atividades } & \multicolumn{6}{|c|}{ Localidades } & \multirow{2}{*}{$\begin{array}{l}\text { Valor } \\
\text { médio }\end{array}$} \\
\hline & v. Cardoso & Lajinha & Jacunã & Piaus & Taquari & Gameleira & \\
\hline Cuidar da casa & $97,3 \%$ & $93,6 \%$ & $100,0 \%$ & $100,0 \%$ & $100,0 \%$ & $100,0 \%$ & $98,8 \%$ \\
\hline Cuidar dos filhos & $81,1 \%$ & $93,6 \%$ & $56,0 \%$ & $100,0 \%$ & $100,0 \%$ & $82,0 \%$ & $83,7 \%$ \\
\hline Trabalhar em casa & $83,8 \%$ & $93,6 \%$ & $84,0 \%$ & $88,2 \%$ & $80,0 \%$ & $86,0 \%$ & $86,1 \%$ \\
\hline Descansar & $95,0 \%$ & $93,6 \%$ & $100,0 \%$ & $100,0 \%$ & $100,0 \%$ & $98,0 \%$ & $97,7 \%$ \\
\hline Trabalhar fora & $32,4 \%$ & $25,0 \%$ & $16,0 \%$ & $44,1 \%$ & $40,0 \%$ & $40,0 \%$ & $34,3 \%$ \\
\hline Lazer & $81,1 \%$ & $93,6 \%$ & $56,0 \%$ & $94,1 \%$ & $100,0 \%$ & $74,0 \%$ & $80,2 \%$ \\
\hline NS/NR & $2,7 \%$ & $6,3 \%$ & $0,0 \%$ & $0,0 \%$ & $0,0 \%$ & $0,0 \%$ & $1,2 \%$ \\
\hline
\end{tabular}

Cuidar da casa foi a atividade mais indicada pela população $(98,8 \%)$ quanto ao uso do tempo, antes ocupado na tarefa de transportar a água e como segunda prioridade encontra-se a resposta descansar (97,7\%). A opção de menor prioridade foi a do trabalho formal fora de casa $(34,3 \%)$.

O efeito indireto sobre o bem estar é apresentado quando a população relata que o tempo antes gasto para busca da água é agora utilizado para o lazer e o descansar. Pode-se também pensar na redução do risco de acidentes domésticos em crianças, consequência do aumento do tempo de presença da mãe em casa. Segundo BURGER (1995), estudos em vários países indicam que o tempo economizado de transporte da água é despendido para produção e preparo de alimentos. Evidências indiretas sugerem que o estado nutricional das crianças pode ser melhorado mesmo que as doenças relacionadas com a água não tenham a sua incidência e/ou prevalência reduzidas. Além da preparação de alimentos, a disponibilidade de tempo da mulher propicia a leitura e o aprendizado de prática de melhores cuidados com a saúde, como, por exemplo, àquelas difundidas pelo PACS, potencializando assim a sua ação. O tempo disponível permite também maior possibilidade de aleitamento decorrendo em um maior aporte nutricional e proteção imunológica das crianças. 
A pouca prioridade dada à procura de emprego é justificada pelo fato de que as localidades têm uma atividade econômica restrita, com pouca oferta de trabalho. A maioria das mulheres possui baixa escolaridade e suas habilidades produtivas restringem-se a atividades domésticas, incluindo a coleta de água, a qual está relacionada com o preparo de alimentos e limpeza da casa. Quando a atividade de coleta e transporte de água é realizada pelos homens, transforma-se numa ocupação profissional remunerada. São chamados de aguadeiros e utilizam o auxílio de animais, bicicleta, camionete e caminhão pipa para otimizar a sua distribuição.

A melhoria na saúde com relação às doenças que a população relata como consequência da ausência de saneamento são apresentadas na tabela 26.

Tabela 26 Priorização da morbidade referida relativa à falta de água antes da implantação do SAA e SES, segundo morbidade e localidades do semi-árido baiano, 2002.

\begin{tabular}{|c|c|c|c|c|c|c|c|}
\hline \multirow[t]{2}{*}{ Agravos } & \multicolumn{6}{|c|}{ Localidades } & \multirow{2}{*}{$\begin{array}{l}\text { Valor } \\
\text { médio }\end{array}$} \\
\hline & V. Cardoso & Lajinha & Jacunã & \begin{tabular}{|l|} 
Piaus \\
\end{tabular} & Taquari & Gameleira & \\
\hline Diarréia & $81,1 \%$ & $50,0 \%$ & $76,0 \%$ & $79,4 \%$ & $70,0 \%$ & $62,0 \%$ & $70,9 \%$ \\
\hline Dores de Barriga & $64,9 \%$ & $12,5 \%$ & $36,0 \%$ & $50,0 \%$ & $50,0 \%$ & $40,0 \%$ & $44,8 \%$ \\
\hline Dores nas Costas & $94,6 \%$ & $93,6 \%$ & $96,0 \%$ & $97,1 \%$ & $80,0 \%$ & $100,0 \%$ & $95,9 \%$ \\
\hline Doença de Pele & $18,9 \%$ & $6,6 \%$ & $12,0 \%$ & $35,3 \%$ & 40,0 & $22,0 \%$ & $22,1 \%$ \\
\hline Não Mudou & $2,7 \%$ & $0,0 \%$ & $0,0 \%$ & $0,0 \%$ & $10,0 \%$ & $0,0 \%$ & $1,7 \%$ \\
\hline Outros & $0,0 \%$ & $0,0 \%$ & $0,0 \%$ & $0,0 \%$ & $0,0 \%$ & $0,0 \%$ & $0,0 \%$ \\
\hline NS/NR & $0,0 \%$ & $6,6 \%$ & $0,0 \%$ & $0,0 \%$ & $0,0 \%$ & $0,0 \%$ & $0,6 \%$ \\
\hline
\end{tabular}

A maior mudança com relação à saúde foi reportada como dores nas costas $(95,9 \%)$ seguidas de diarréia $(70,9 \%)$, dores de barriga $(44,87 \%)$ e doenças de pele $(22,1 \%)$. Em Lajinha e Taquari, a população relata uma menor queixa de dores nas costas (93,5\% e $80 \%$ respectivamente), provavelmente por transportar pouca água para as residências, utilizando-as diretamente nas margens do rio ou do açude. 
A literatura técnica costuma não incluir o relato de dores nas costas como um fator associado à falta de sistema de abastecimento de água. $\mathrm{O}$ constante carregar de lata d'água na cabeça, além do desconforto, reduz ou impossibilita a realização de outras tarefas e pode a longo prazo ocasionar danos crônicos na coluna vertebral. Outros fatores ao longo da vida de um indivíduo morador da zona rural podem também levar a problemas na coluna vertebral, porém a constância de um peso excessivo sobre a coluna cervical desde a infância é provavelmente um fator relevante que contribui para esta situação. A fígura 21, a seguir, mostra uma criança em Gameleira carregando uma lata de água, distando cerca de 800 metros da fonte. $\mathrm{Na}$ figura 22 tem-se uma moradora de Jacunã trazendo água da aguada.

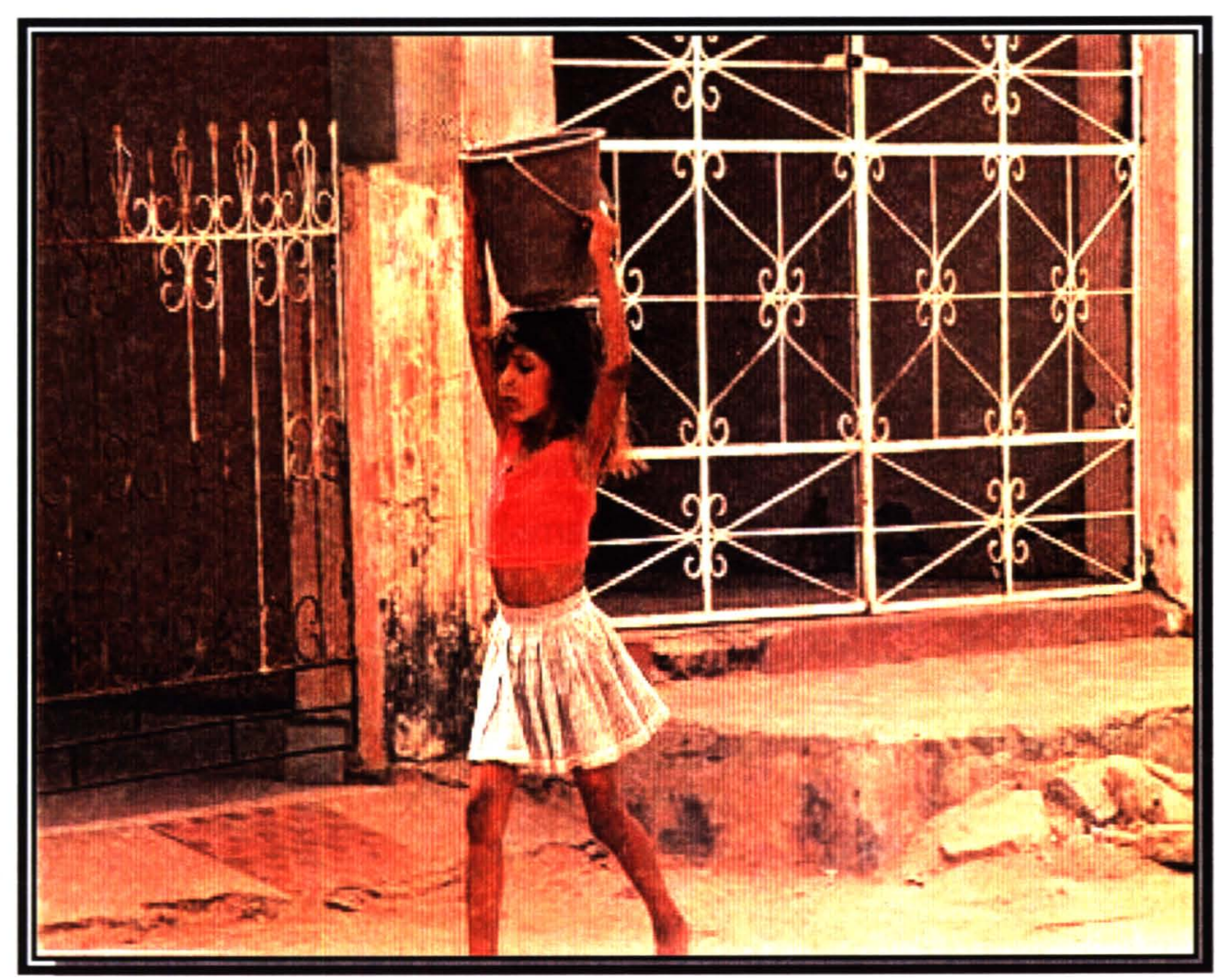

Figura 21 Criança em Gameleira carregando uma lata de água na cabeça. 


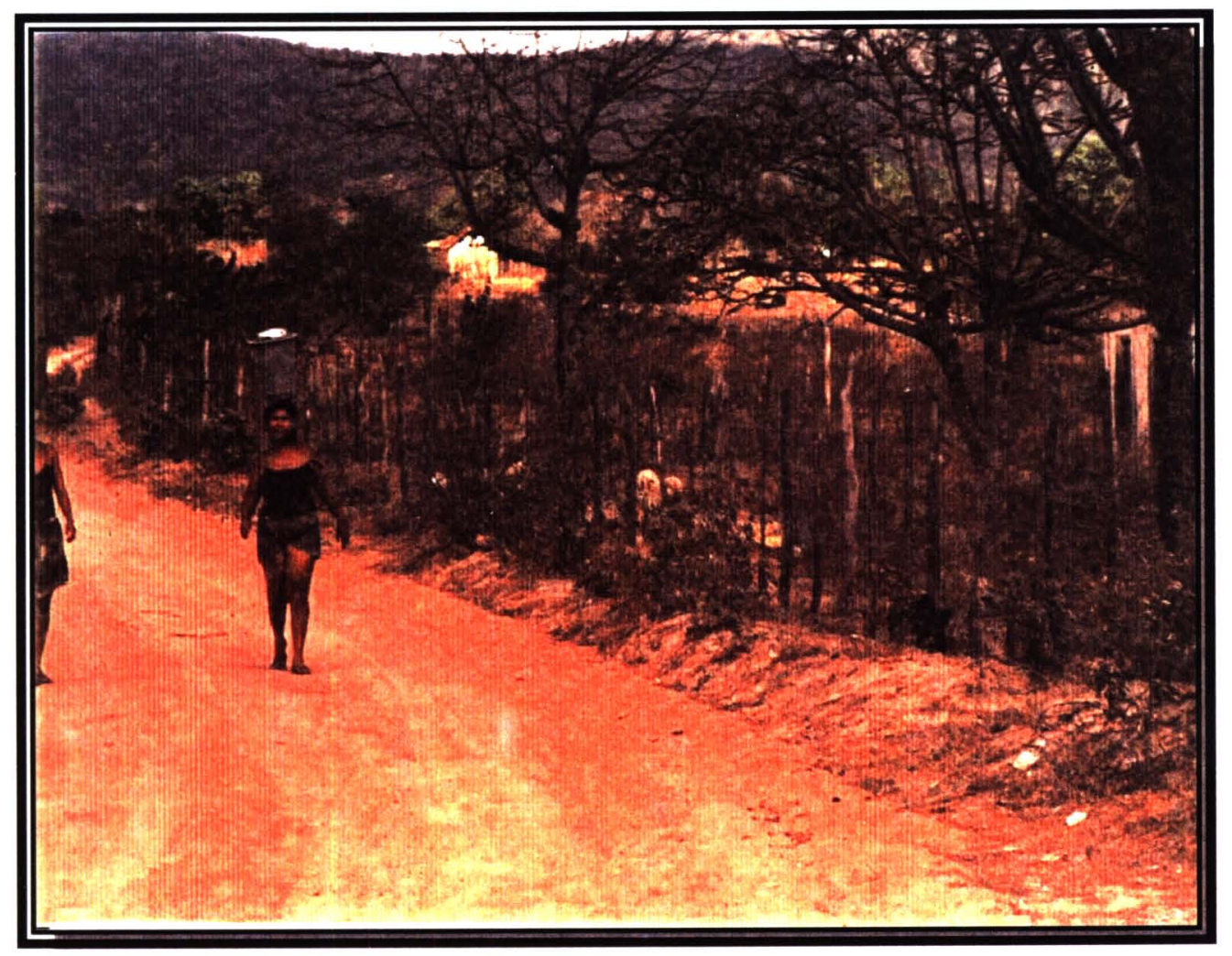

Figura 22 Moradora de Jacunã transportando água da aguada.

Os resultados descritos a seguir referem-se às informações coletadas nos questionários aplicados na amostra da população, com relação aos hábitos sanitários antes e após a implantação do sistema de saneamento. No Apêndice $C$ encontram-se os resultados apresentados nas tabelas 34 a 51 com a freqüência de todas as alternativas respondidas.

Muitos moradores, quando possível, costumavam utilizar dois tipos de fontes de água. Uma para consumo geral (chamada de água de gasto), e outra para beber e cozinhar alimentos. A compra da água pode ser feita para todo o consumo doméstico, ou apenas para usos mais nobres como bebida $\mathrm{e}$ preparo de alimentos, utilizando-se de outras fontes menos seguras para os outros usos. Estas opções variam em função do tipo de manancial de cada localidade e pelas condições financeiras de cada família.

As fontes de água para beber variaram em função da própria disponibilidade local, sendo comum o caminhão pipa (26\%) e o poço, represa, açude ou rio 
existente em cada localidade. Após a implantação do sistema de saneamento há a eliminação da compra da água de carro pipa e o uso da água da Central passam para um percentual de $57 \%$. Cerca de $27 \%$ das pessoas utilizam água de cisterna coletada pela chuva $e$ as demais ainda utilizam o poço e a barragem.

A população justifica a escolha da água proveniente de poço ou de barragem pelo sabor da água, consequência de um maior teor de sais ou pela rejeição ao cloro adicionado para desinfecção da água do SAA, ainda que esses teores estejam dentro dos limites de potabilidade. Na maioria das pequenas cidades do interior é comum a população utilizar outras fontes de água para beber, motivada pela falta de confiança na qualidade da água distribuída ou pelas suas propriedades organolépticas. O processo de adaptação da população para um novo sabor da água pode ser lento e campanhas educativas poderiam ser promovidas para acelerar essa mudança.

A prática mais comum encontrada para o armazenamento da água foi em recipientes como baldes $(30 \%)$, potes $(23 \%)$ e tonéis $(23 \%)$, muitas vezes instalados em frente à casa. Após o SAA, a mudança mais significativa foi a do armazenamento em caixas d'água que passou de $8 \%$ para $22 \%$ ao passo que a prática de armazenamento em baldes diminuiu para $13 \%$.

Anteriormente à instalação dos sistemas de saneamento predominavam as práticas de coar e filtrar a água (52\%). A cloração era uma prática usual (21\%), havendo também o hábito de criar peixes no reservatório $(8,4 \%)$ com o objetivo de manter a água limpa, principalmente de larvas de insetos. Após a implantação desses sistemas, o tratamento doméstico da água concentrou-se no ato de coar e filtrar a água, conforme informaram $90 \%$ dos entrevistados.

A mudança mais significativa com relação ao local de lavagem de mãos e de alimentos relaciona-se à redução do uso da bacia e ao aumento do uso da 
água corrente da torneira da pia ou do tanque. A frequência de uso da bacia para lavagem de alimentos diminuiu de $61 \%$ para $42 \%$, ao passo que o uso de torneira aumentou de $37 \%$ para $42 \%$. No caso da lavagem de mãos a frequência do uso da bacia cai de $61 \%$ para $41 \%$, ao contrário do uso da torneira que passa de $39 \%$ para $59 \%$. As dores nas costas relatadas pela população são consequências também da postura corporal incorreta quando da realização de atividades de lavagem de roupa e de utensílios domésticos em bacias no chão.

As mudanças da prática de lavagem de roupa variam em cada localidade em função do tipo de água disponível para esta atividade. Na localidade de Lajinha, onde há um rio perene, com pedras no seu leito que facilitam o acesso da população às suas águas, a redução foi apenas de $48 \%$ para $40 \%$. Em locais com água pouco disponível e visivelmente contaminada como o caso de Jacunã e Gameleira, houve quase que uma eliminação dessa prática ( $4 \%$ e $0 \%$ respectivamente). Como a lavagem de roupa em fontes abertas é uma prática cultural e de economia na despesa da conta de água, tem-se ainda a continuidade da lavagem de roupa em chafariz, represa e rio.

Após a instalação dos módulos sanitários compostos de vaso hídrico e de ponto para chuveiro, a prática do banho neste local aumentou de $46 \%$ para $92 \%$. Nas localidades de Lajinha e de Taquari, $11 \%$ e $10 \%$ respectivamente, ainda utilizam a represa ou o rio. Contudo, anteriormente, os percentuais anteriores eram de $44 \%$ e $42 \%$ respectivamente.

A prática de defecar em locais abertos, com grandes riscos de contaminação do meio, foi reduzida de $28,4 \%$ para $4 \%$, e o uso do sanitário que era de $65 \%$ passou para $95 \%$. Antes do programa de saneamento, os sanitários existentes na maioria das residências eram do tipo Fossa Seca, que, embora ofereça uma condição sanitária adequada, não possui o conforto e a praticidade do vaso hídrico. Cerca de $65 \%$ das famílias utilizavam esta 
instalação sanitariamente segura, enquanto $35 \%$ restantes utilizavam meios sanitariamente inadequados tais como a céu aberto. Na situação posterior, 97\% das famílias utilizam o sanitário conectado à rede de esgotamento sanitário restando $3 \%$ que corresponde a residências de Vila Cardoso e de Lajinha que não fizeram ligação com o sistema de água, ficando assim fora do programa. A presença de torneira no sanitário e a condução dos esgotos domésticos, em especial as fezes e urina, para tratamento e destino final adequado possibilita o corte, em médio prazo, do ciclo das doenças associadas à falta de esgoto.

Além das instalações sanitárias construídas dentro do programa de saneamento, verificou-se que $41 \%$ das residências foram acrescidas de pia de cozinha, $32,8 \%$ de tanque de lavar roupa e $37 \%$ de chuveiro.

Como são obras que necessitam de recursos financeiros, sua execução não se dá logo após a implantação de obras de saneamento e sim com o passar do tempo, quando a população absorve novos hábitos e consequentemente procura conseguir recursos financeiros para tais melhorias.

Na pergunta sobre os tipos de equipamentos hidrosanitários que pretende implantar posteriormente, $71 \%$ dos entrevistados optaram pelo tanque de lavar roupa e $65,5 \%$ pelo lavatório.

Ressalte-se que nas localidades de Gameleira e Jacunã os SAA e SES haviam sido implantados há apenas 4 meses, sendo um período ainda pequeno para uma família planejar e provisionar recursos para obras dentro de casa.

A análise das respostas sobre as práticas sanitárias indicou a possibilidade de agrupar em 3 níveis relacionados com a condição de segurança sanitária dessas práticas, que são descritas a seguir: 
Nível 1 Práticas sanitárias adequadas.

São práticas com probabilidade de ocorrência de contaminação pequena ou nula. Esta condição pode ser exemplificada com a água potável distribuída em domicilio, sob pressão e sem intermitência.

Nível 2 Práticas sanitárias com potencial de contaminação.

São práticas como a situação de se buscar água no chafariz proveniente de um poço profundo onde a água é potável, mas o modo de coletar, transportar e armazenar pode (ou não) vir a contaminá-la.

Nível 3 Práticas sanitárias inadequadas.

São práticas em que é visível a contaminação da mesma como a uso de água de "aguadas".

A classificação das respostas em função dos grupos descritos acima é apresentada junto às perguntas do questionário, no Apêndice A. As figuras 23 a 42 a seguir apresentam as respostas categorizadas para as condições anteriores e posteriores à implantação do sistema de saneamento. As respectivas tabelas encontram-se no Apêndice $D$. Utilizando como indicador a classificação dos grupos pela sua qualidade sanitária tem-se que:

- Anteriormente, em relação à água utilizada para beber, predominava a classificação do Nível $2(68,4 \%)$, que passa a ter uma frequência de $6,4 \%$ e o Nível 1, inexistente anteriormente, passa para uma frequência de $42,7 \%$.

- A lavagem de alimentos que antes tinha uma frequência de $54,4 \%$ no Nível 3, passa para os Níveis 2 e 1, sendo que neste, a frequência passa de $17 \%$ para $54 \%$.

- A lavagem das mãos demonstra também um aumento na frequência do Nível 1, muito embora de pequeno valor, passando de $34,5 \%$ para $51 \%$. A pia é ainda um equipamento pouco comum nas residências das localidades. 




Figura 23 Armazenamento da água antes do saneamento, segundo frequência, níveis de saneamento e localidades do semi árido baiano, 2002



Figura 25 Origem da água de beber antes do saneamento, segundo frequência, níveis de saneamento e localidades do semiárido baiano, 2002.



Figura 24 Armazenamento da água depois do saneamento, segundo frequência, níveis de saneamento e localidades do semi-árido baiano, 2002.

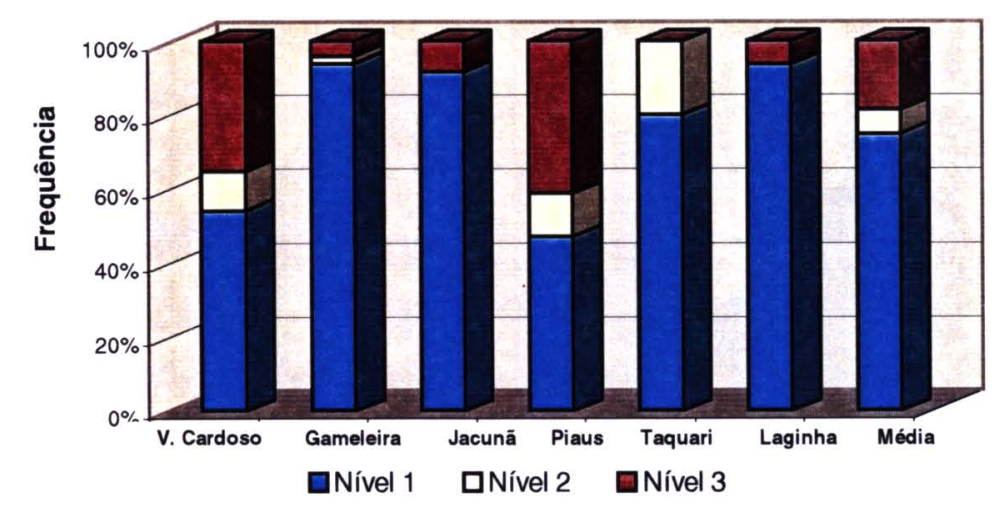

Figura 26 Origem da água de beber depois do saneamento, segundo frequência, níveis de saneamento e localidades do semiárido baiano, 2002. 


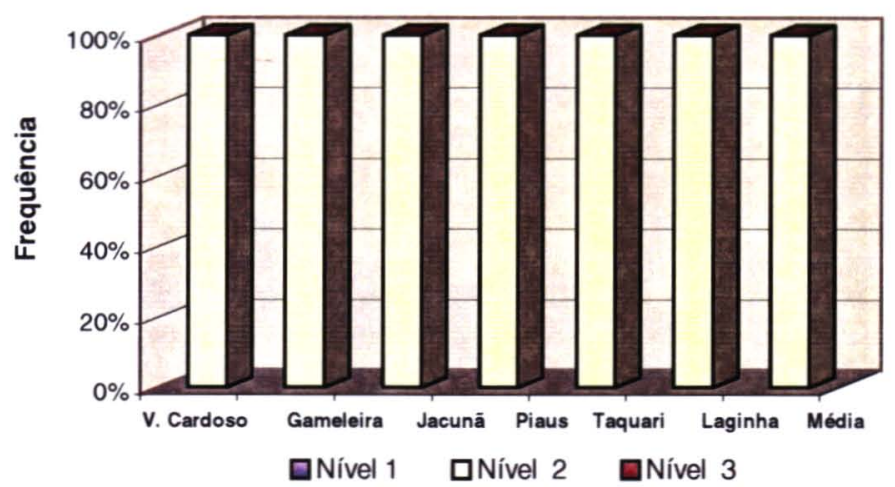

Figura 27 Tipo de tratamento de água antes do saneamento, segundo frequência, niveis de saneamento e localidades do semi árido baiano, 2002

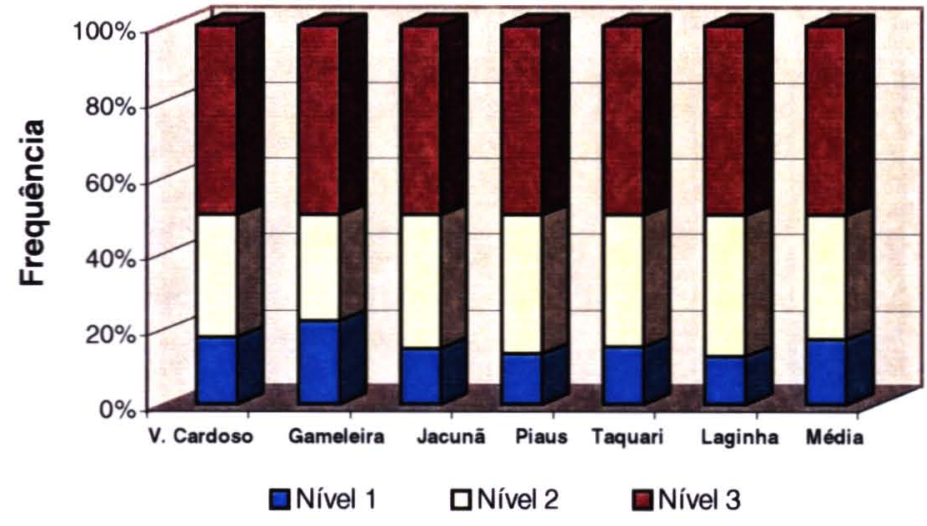

Figura 29 Local de lavagem de alimentos antes do saneamento, segundo frequência, níveis de saneamento e localidades do semi árido baiano, 2002.

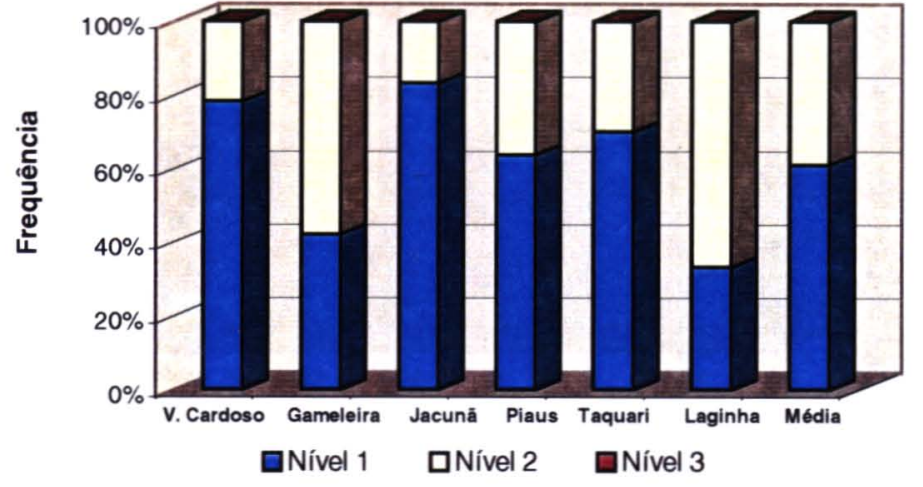

Figura 28 Tipo de tratamento de água depois do saneamento, segundo frequência, níveis de saneamento e localidades do semi árido baiano, 2002.

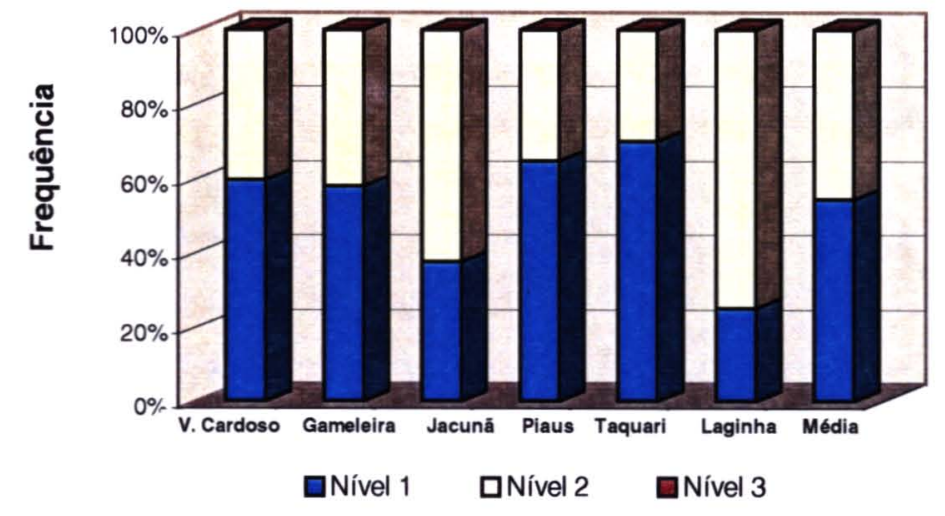

Figura 30 Local de lavagem de alimentos depois do saneamento, segundo frequência, níveis de saneamento e localidades do semi árido baiano, 2002. 


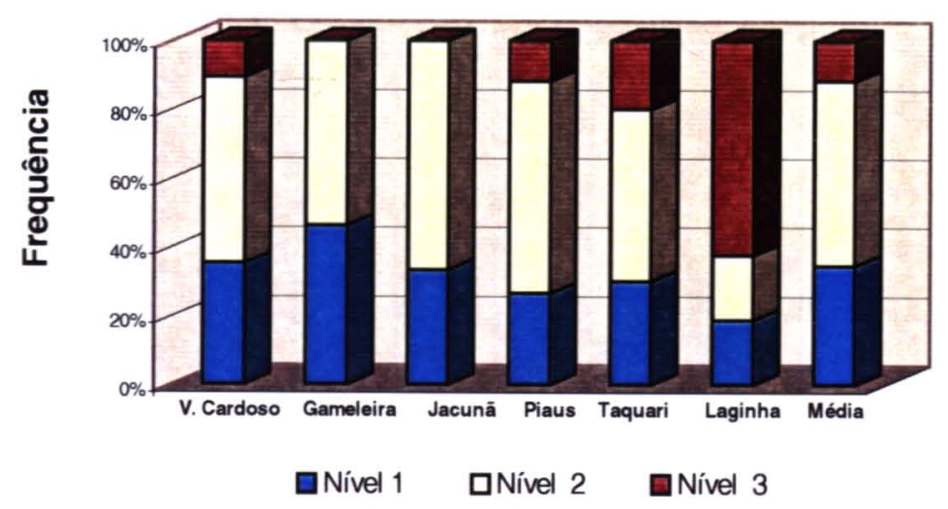

Figura 31 Local de lavagem dos utensilios domésticos antes do saneamento, segundo frequência, níveis de saneamento e localidades do semi-árido baiano, 2002.

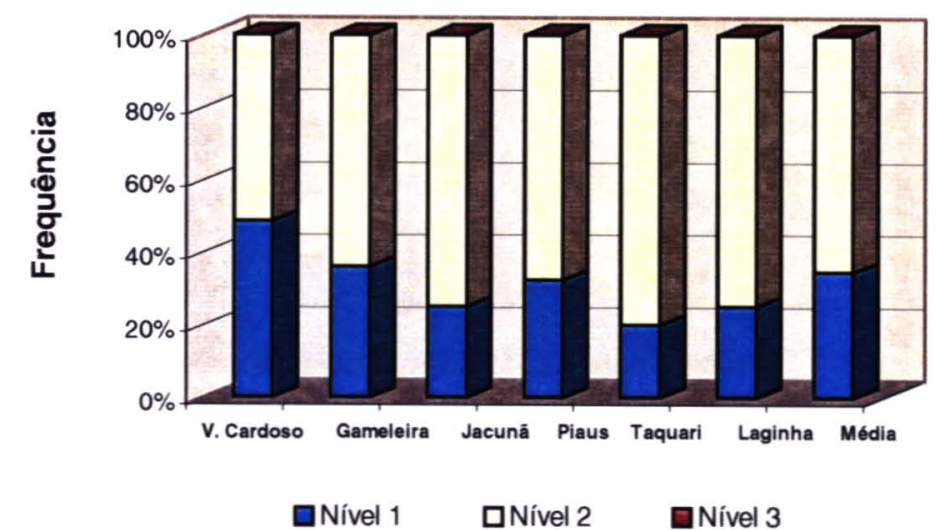

Figura 33

Local de lavagem das mãos antes do saneamento, segundo frequência, níveis de saneamento e localidades do semi árido baiano, 2002.

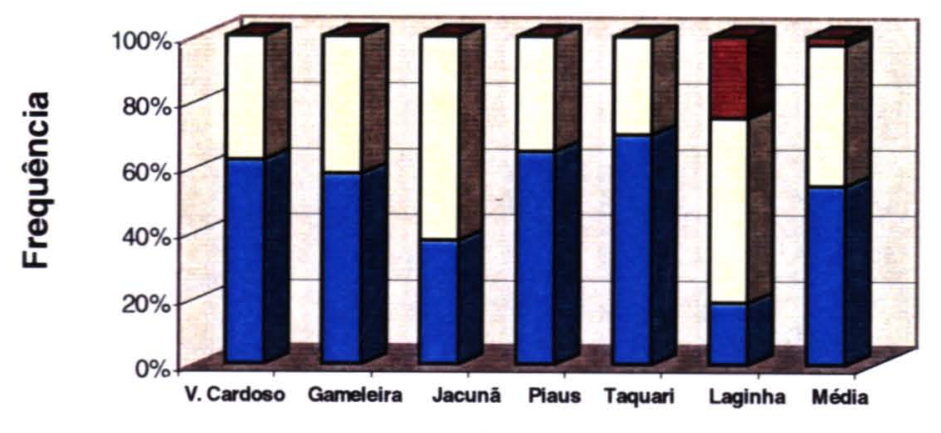

口Nível 1 aNivel 2 日Nível 3

Figura 32 Local de lavagem dos utensílios domésticos depois do saneamento, segundo frequência, níveis de saneamento e localidades do semi árido baiano, 2002.

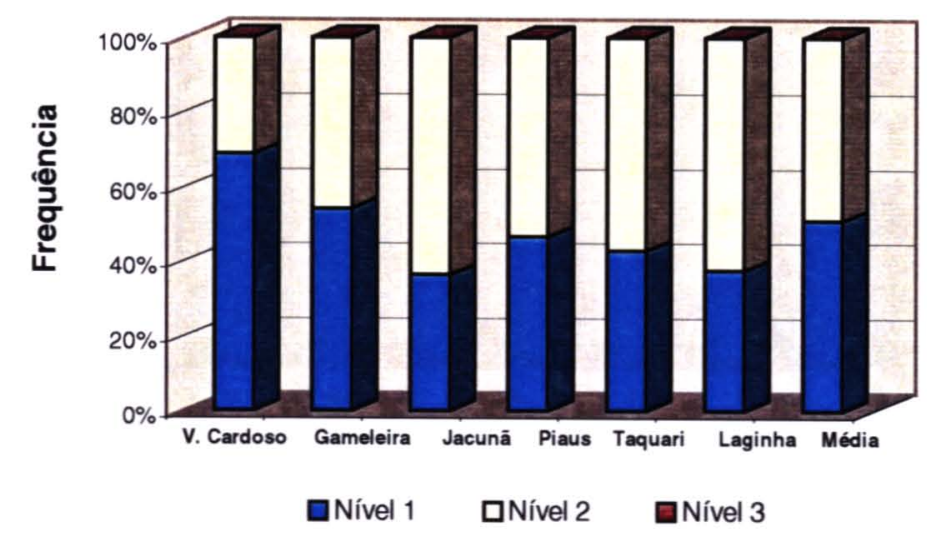

Figura 34

Local de lavagem das mãos depois do saneamento, segundo frequência, níveis de saneamento e localidades do semi árido baiano, 2002 


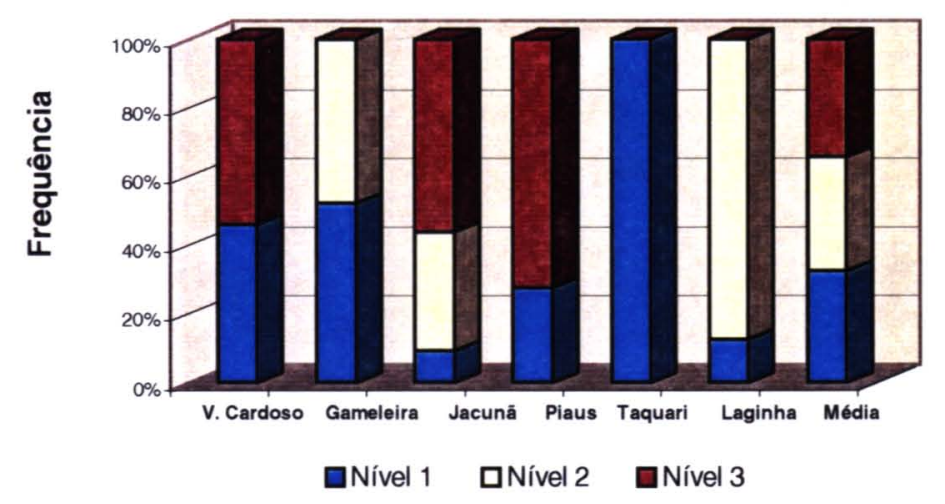

Figura 35 Local de lavagem de roupas antes do saneamento, segundo frequência, niveis de saneamento e localidades do semi árido baiano, 2002.

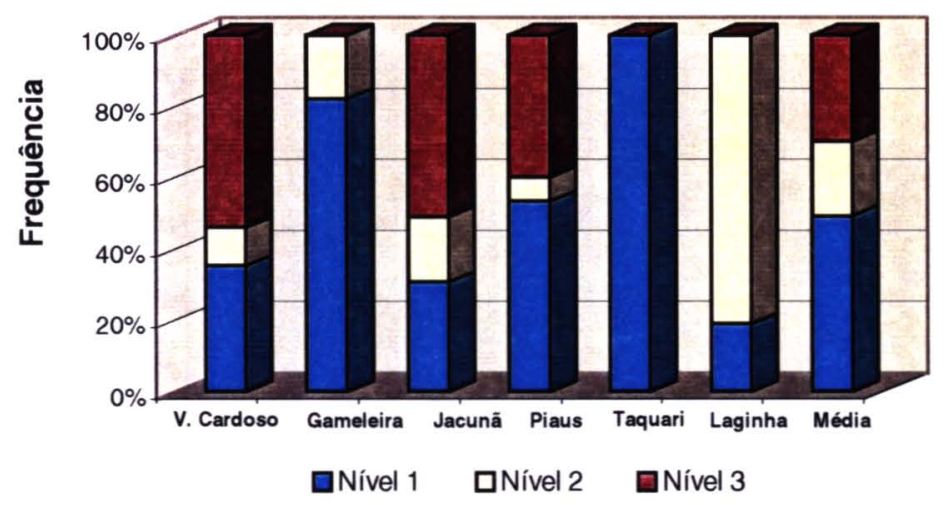

Figura 37 Local de banho antes do saneamento, segundo frequência níveis de saneamento e localidades do semi árido baiano, 2002

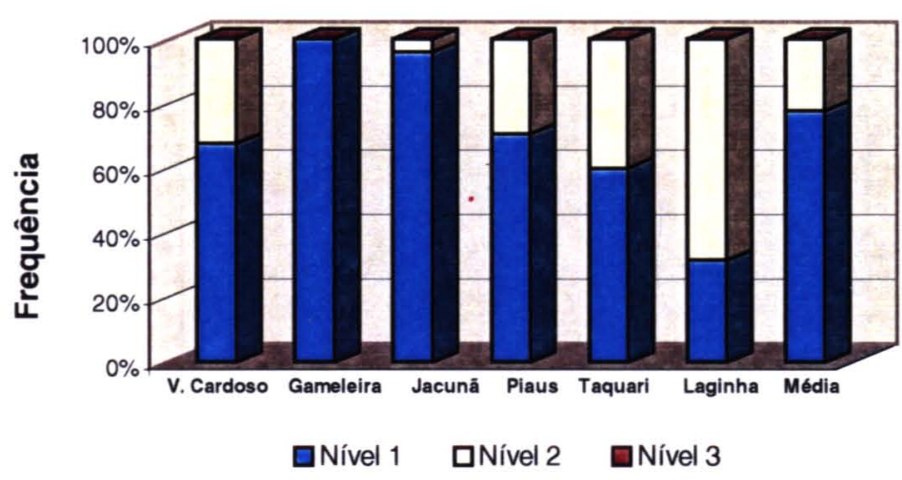

Figura 36 Local de lavagem das roupas depois do saneamento, segundo frequência, niveis de saneamento e localidades do semi árido baiano, 2002.

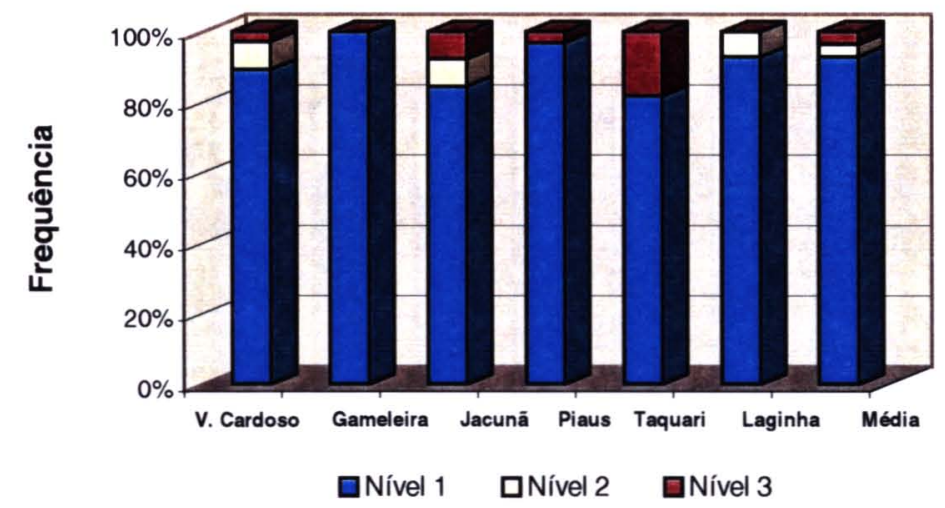

Figura 38 Local de banho depois do saneamento, segundo frequência, niveis de saneamento e localidades do semi árido baiano, 2002. 


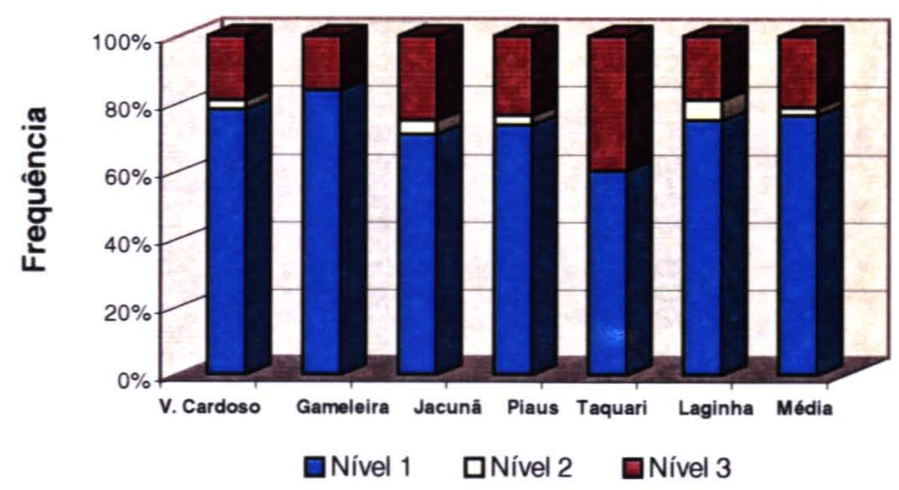

Figura 39 Local utilizado para defecar antes do saneamento, segundo frequência, níveis de saneamento e localidades do semi árido baiano, 2002.

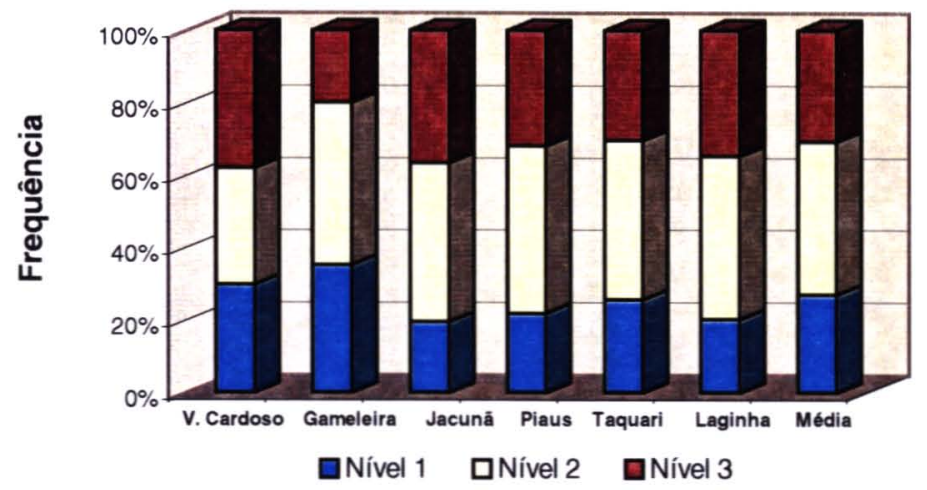

Figura 41 Práticas sanitárias antes do saneamento segundo frequência, níveis de saneamento e localidades do semi árido baiano, 2002

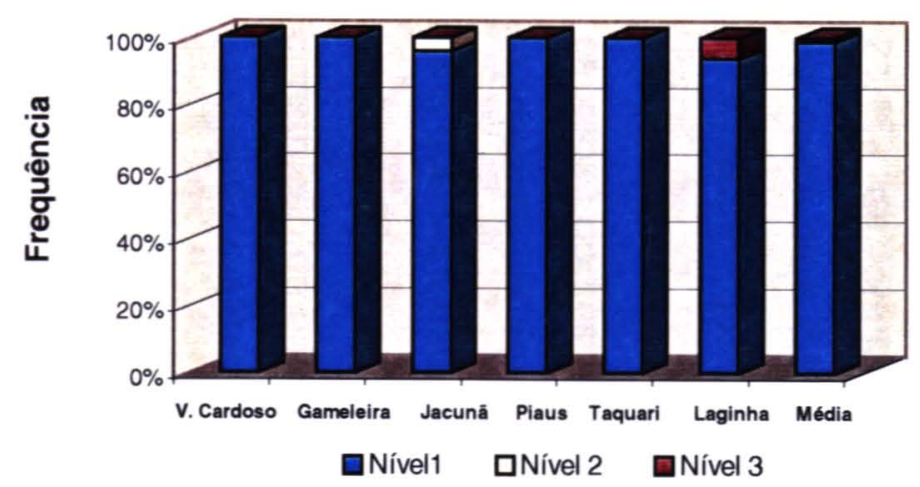

Figura $\mathbf{4 0}$

Local utilizado para defecar depois do saneamento, segundo frequência, níveis de saneamento e localidades do semi árido baiano, 2002.

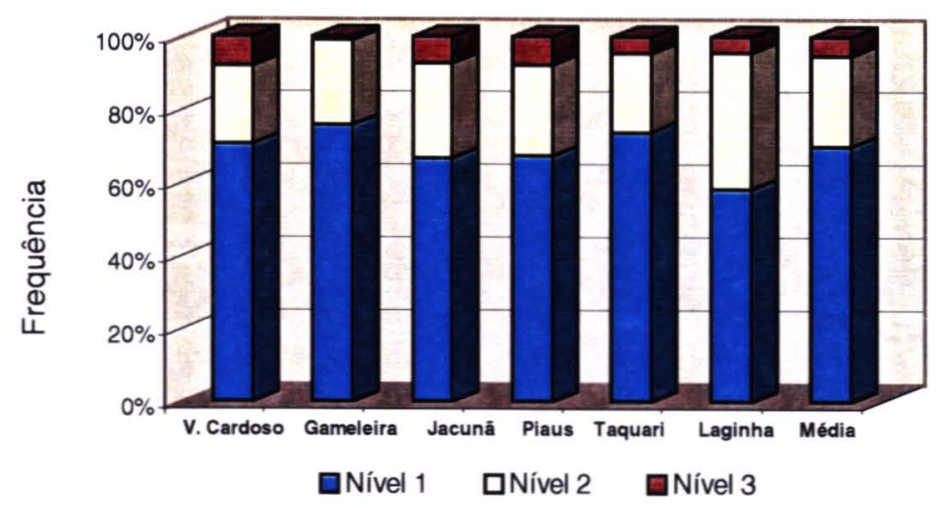

Figura 42 Práticas sanitárias depois do saneamento segundo frequência, níveis de saneamento e localidades do semi árido baiano, 2002. 
O local de defecar é um fator importante no controle de doenças associadas com o esgoto sanitário. Anteriormente ao programa havia uma frequência de $21,1 \%$ de práticas sanitárias inadequadas (Nível 3). Essa frequência decresce para $0,6 \%$, diferentemente da do Nível 1 - práticas sanitariamente adequadas - que passou para $98,8 \%$. A construção dos sanitários, prevista pelo programa, é um fator importante para garantia da destinação dos esgotos domésticos. Seu custo orçado em $\mathbf{R} \$ 350,00$ por domicílio representa um acréscimo no custo per capita de aproximadamente $\mathrm{R} \$ 70,00$, mas que sem este equipamento, os benefícios à saúde e ao meio ambiente podem não ser alcançados. GUIMARÃES (1987) ressalta que a prática de construção de esgotamento sanitária é como o início das suas obras a partir da ligação predial, e não a partir do sanitário pelo fato de que historicamente o poder público tem implantado esses sistemas em área da cidade de classe média e alta, cujas residências já possuiam, evidentemente, instalação sanitária domiciliar.

$\mathrm{Na}$ condição anterior a frequência das atividades do Nível 1 era de $27 \%$ passando posteriormente para $69,9 \%$ representando um acréscimo de $35,9 \%$ ao passo que a frequência do Nível 3 decresceu de $30,6 \%$ para $5,2 \%$.

Tanto antes quanto depois da implantação do sistema de saneamento, observa-se que as localidades de Jacunã, Piaus e Lajinha, são as que apresentam esses indicadores com valores abaixo da média.

Em Lajinha, a disponibilidade de um rio perene junto à localidade contribui para a continuidade uma maior continuidade dos seus hábitos anteriores.

Gameleira e Jacunã pertencem ao mesmo município (Jaguarari) e distam-se cerca de $5 \mathrm{~km}$, porém a assimilação da nova realidade apresenta-se diferente para cada uma dessas duas localidades. Também, Piaus e Taquari 
pertencem ao mesmo município (Itiúba) e distam-se a menos de $10 \mathrm{~km}$ com sistemas implantados simultaneamente, mas os resultados são diferentes.

Jacunã e Piaus são comunidades com menos capacidade organizacional e recursos financeiros e percebe-se essas consequências nos aspectos de limpeza, infra-estrutura, trato da população com a fachada e a calçada da sua casa.

As tabelas 27,28 e 29 a seguir sintetizam os relatos dos presidentes das associações de moradores das localidades estudadas em relação às mudanças ocorridas nas mesmas, após a implantação dos sistemas de saneamento.

Tabela 27 Alterações no valor do imóvel para compra e aluguel e número de residências nas localidades, segundo informação dos presidentes das associações de moradores das localidades estudadas, após a implantação dos sistemas de saneamento.

\begin{tabular}{|l|l|l|}
\hline Localidade & \multicolumn{1}{|c|}{ Valor do imóvel } & \multicolumn{1}{|c|}{ Aumento do numero de casas } \\
\hline V. Cardoso & $\begin{array}{l}\text { Hoje é difícil encontrar casa para alugar. } \\
\text { O aluguel de uma casa era de } \mathrm{R} \$ 15,00 \text { a } \\
\mathrm{R} \$ 20,00 \text { por mês. Hoje vai de } \mathrm{R} \$ 50,00 \text { a } \\
\mathrm{R} \$ 80,00 \text {. Uma casa que se vendia por } \\
\mathrm{R} \$ 2.500, \text { hoje é vendida por } \mathrm{R} \$ 5.000 \text { a } \\
\mathrm{R} \$ 6.000 .\end{array}$ & $\begin{array}{l}\text { Antes } \\
\text { fechadas. Hoje estão ocupadas e } \\
\text { com mais construções. }\end{array}$ \\
& $\begin{array}{l}\text { Com a chegada do programa, aluguéis e } \\
\text { venda de terrenos aumentaram numa } \\
\text { faixa de } 50 \% .\end{array}$ & $\begin{array}{l}\text { Estão surgindo novas construções, } \\
\text { por conta do retorno de famílias } \\
\text { que residiam em outras cidades, } \\
\text { expulsas pela carência de água. } \\
\text { No momento são 12 casas novas }\end{array}$ \\
\hline Jacunã & $\begin{array}{l}\text { O preço de aluguel e de venda } \\
\text { permanece os mesmos }\end{array}$ & $\begin{array}{l}\text { Já tem uma rua nova com } 26 \\
\text { casas }\end{array}$ \\
\hline Piaus & $\begin{array}{l}\text { Depois do programa valorizou bastante } \\
\text { para venda de casas. }\end{array}$ & $\begin{array}{l}\text { Surgiram alguns moradores e mais } \\
\text { algumas construções. }\end{array}$ \\
\hline Taquari & $\begin{array}{l}\text { Antes o valor do aluguel era menor e } \\
\text { dificilmente se vendia uma casa. Depois } \\
\text { esse valor aumentou e a venda também. }\end{array}$ & $\begin{array}{l}\text { Aumentou o número de casas, } \\
\text { habitantes e 6 novas construções } \\
\text { foram feitas. }\end{array}$ \\
\hline Lajinha & $\begin{array}{l}\text { Até o momento não houve nenhuma } \\
\text { alteração em aluguel. As casas têm mais } \\
\text { valor se são de bloco, ou alvenaria, Se é } \\
\text { de adobe e não tem água fica difícil até } \\
\text { de alugar. }\end{array}$ & $\begin{array}{l}\text { Apesar de Lajinha, não poder } \\
\text { crescer muito porque é cercada de } \\
\text { fazendas, cresceu um pouco. Os } \\
\text { terrenos vazios já foram quase } \\
\text { todos construídos. }\end{array}$ \\
\hline
\end{tabular}


Tabela 28 Mudanças nas localidades após implantação de sistema de saneamento segundo informação dos presidentes das associações de moradores das localidades estudadas, após a implantação dos sistemas de saneamento.

\begin{tabular}{|l|l|}
\hline Localidade & \multicolumn{1}{c|}{ Mudanças na Localidade } \\
\hline V. Cardoso & $\begin{array}{l}\text { Antes aqui era abandonado. O pessoal da prefeitura de Caém veio aqui e } \\
\text { parabenizou 100\%. A água é sadia, eu mesmo quando vou para a roça, me } \\
\text { acostumei que não bebo mais a água de lá. Levo água daqui. }\end{array}$ \\
\hline Gameleira & $\begin{array}{l}\text { Muitas: A qualidade de vida como consequência do saneamento básico. O } \\
\text { ritmo de vida das pessoas: economia de tempo por não carregar mais água } \\
\text { e a diminuição das doenças. }\end{array}$ \\
\hline Jacunã & A água e o tratamento de esgoto evita doenças \\
\hline Piaus & Sim, por que temos água tratada e hoje temos telefone residencial. \\
\hline Taquari & Sim, houve, principalmente na saúde. \\
\hline Lajinha & $\begin{array}{l}\text { Claro, sem dúvida nenhuma. Água 24 horas na torneira que antes era } \\
\text { grande o sofrimento da população, até mesmo para a construção de casas, } \\
\text { reformas e tudo mais. }\end{array}$ \\
\hline
\end{tabular}

Tabela 29 Outras atividades comunitárias das associações de moradores das localidades estudadas, após a implantação dos sistemas de saneamento.

\begin{tabular}{|l|c|c|c|c|c|c|c|}
\hline Localidade & $\begin{array}{c}\text { Operação } \\
\text { do } \\
\text { SAA/SES }\end{array}$ & $\begin{array}{c}\text { Casa } \\
\text { de } \\
\text { Farinha }\end{array}$ & $\begin{array}{c}\text { Coleta } \\
\text { de } \\
\text { Lixo }\end{array}$ & Festas & $\begin{array}{c}\text { Auxílio } \\
\text { à } \\
\text { Saúde }\end{array}$ & $\begin{array}{c}\text { Auxílio para } \\
\text { Aposentadoria }\end{array}$ & Fábrica \\
\hline V. Cardoso & $\mathrm{X}$ & & $\mathrm{X}$ & & $\mathrm{X}$ & & $\mathrm{X}$ \\
\hline Gameleira & $\mathrm{X}$ & $\mathrm{X}$ & & $\mathrm{X}$ & $\mathrm{X}$ & & \\
\hline Jacunã & $\mathrm{X}$ & & $\mathrm{X}$ & & & & \\
\hline Piaus & $\mathrm{X}$ & & $\mathrm{X}$ & & & & \\
\hline Taquari & $\mathrm{X}$ & & & & $\mathrm{X}$ & $\mathrm{X}$ & \\
\hline Lajinha & $\mathrm{X}$ & $\mathrm{X}$ & $\mathrm{X}$ & & & & \\
\hline
\end{tabular}

Percebe-se que todas as associações acrescentaram pelo menos uma atividade comunitária após o inicio da operação do SAASES. O tipo de atividade depende da demanda da comunidade, da capacidade organizacional da associação e das oportunidades existentes na região.

Em Piaus, foi observado que a coleta e a disposição final do lixo era visivelmente inadequada e demonstrava um mau trato da população pelo seu local de morada. Sendo um local de comércio de feira de abastecimento também para as localidades vizinhas, havia uma produção de lixo adicional e sem uma responsabilidade direta da coleta. Em Lajinha, os lotes são pequenos e não há quintais com fundo aberto, pois a localidade é 
contornada por fazendas de gado e a população costuma lançar o lixo na rua, causando mau cheiro e proliferando vetores de doenças. Em ambos os casos a Associação de moradores mostrou-se ativa em organizar a coleta dos resíduos sólidos.

Quanto à atividade relativa à casa de farinha, esta tem uma construção simples, mas ainda assim com um custo de implantação superior à capacidade financeira das associaçōes. Como nos sistemas de água e de esgoto, esse tipo de equipamento é, na maioria das vezes, construído pelo Governo do Estado, através de programas para geração de renda, e entregues às associações locais em regime de comodato.

A atividade de auxílio à saúde refere-se ao custeio parcial do transporte de pacientes para a sede municipal para atendimento de emergência, assim como o auxilio à aposentadoria. A associação auxilia também o preenchimento de formulários e obtenção de documentos necessários para se solicitar a aposentadoria ao INSS.

A localidade de Gameleira é visivelmente mais organizada e a população demonstra maior envolvimento em atividades comunitárias. As festas que a associação promove visam, além do entretenimento, à arrecadação de verbas para melhorias na localidade. Muitas destas são organizadas em parceria com o sindicato rural e organizações pastorais da igreja católica inferindo-se assim que um sistema de abastecimento de água e de esgotamento implantado nesse modo associativo passa a ser um vetor de mobilização comunitária para melhoria de outros serviços de saneamento (coleta de resíduos sólidos), saúde e bem estar. GÜNTHER e RIBEIRO (2000) relatam mudanças na população com relação a atitudes e de práticas arraigadas para uma forma sanitária e ambientalmente adequada, bem como a criação e fortalecimento de grupos comunitários, após ações de educação ambiental em comunidades rurais do estado de São Paulo. 
A maioria dos presidentes relatou a ocorrência do aumento do valor do imóvel, sendo que no caso de Gameleira e Vila Cardoso, é citado um acréscimo de $50 \%$ no valor de venda. A procura desses imóveis se dá geralmente por antigos moradores do local que hoje vivem na sede do município e em muitos casos por aqueles que migraram para o estado de São Paulo, e que, já aposentados, adiavam o retorno pela falta de condições de infra-estrutura da localidade, em especial a inexistência de "água encanada".

Observa-se que quando o valor do terreno ou do imóvel é baixo, a população tende a fazer poucas benfeitorias nas residências, pois este investimento agrega pouco valor ao patrimônio. A tendência é fazer o mínimo de melhorias e, se houver mais recursos financeiros, mudar para um local com melhor estrutura de apoio (geralmente as cidades maiores), aumentando assim o grau de urbanização da população. No sentido inverso tem-se a fixação da população no campo.

Nas localidades em que não houve mudança de valor de aluguel e de venda de imóveis, a construção de novas casas tem suprido a demanda dos novos moradores.

A localidade de Lajinha, diferentemente das outra localidades da pesquisa, sempre teve água disponivel ao longo de todo o ano e em quantidade para todos, não havendo problemas de cotas nem de filas para sua obtenção. A população utilizava (e ainda utiliza parcialmente) o rio, como extensão das suas moradias no que se refere às tarefas que necessitem de água. A roupa e os utensílios domésticos eram lavados no rio, e, em pontos distintos e reservados, as mulheres e os homens utilizavam 0 rio para banho $e$ sanitário. A água de beber era captada da chuva, ou mesmo trazida de outras fontes, mas o pequeno volume não representava maiores transtornos. O problema relatado ocorria por ocasião da necessidade de se trazer água para a residência para uso na construção civil. 
A tabela 30 apresenta a destinação dada ao valor arrecadado pela cobrança mensal da conta de água referente ao serviço de saneamento prestado, conforme relato do entrevistados.

Tabela 30 Destino do valor arrecadado pela conta de água após implantação do SAA e SES, segundo localidades do semi-árido baiano, 2002.

\begin{tabular}{c|c|c|c|c|c|c|c}
\hline \multirow{2}{*}{ Destino } & \multicolumn{6}{|c|}{ Localidades } & Valor \\
\cline { 2 - 7 } & $\begin{array}{c}\text { Vila } \\
\text { Cardoso }\end{array}$ & Lajinha & Jacunã & Piaus & Taquari & Gameleira & médio \\
\hline $\begin{array}{c}\text { Operador, Energia } \\
\text { e Manutenção. }\end{array}$ & $13,5 \%$ & $37,5 \%$ & $12,0 \%$ & $14,7 \%$ & $30,0 \%$ & $6,0 \%$ & $14,6 \%$ \\
\hline $\begin{array}{c}\text { Operador, Energia } \\
\text { e Central. }\end{array}$ & $2,7 \%$ & $0,0 \%$ & $0,0 \%$ & $2,9 \%$ & $0,0 \%$ & $0,0 \%$ & $1,2 \%$ \\
\hline Central & $8,1 \%$ & $0,0 \%$ & $4,0 \%$ & $5,9 \%$ & $10,0 \%$ & $10,0 \%$ & $7,0 \%$ \\
\hline Manutenção & $8,1 \%$ & $0,0 \%$ & $0,0 \%$ & $0,0 \%$ & $10,0 \%$ & $6,0 \%$ & $4,1 \%$ \\
\hline CERB & $2,7 \%$ & $0,0 \%$ & $4,0 \%$ & $5,9 \%$ & $10,0 \%$ & $0,0 \%$ & $2,9 \%$ \\
\hline Não sabe & $64,9 \%$ & $62,5 \%$ & $80,0 \%$ & $70,6 \%$ & $40,0 \%$ & $78,0 \%$ & $70,4 \%$ \\
\hline Total & $100,0 \%$ & $100,0 \%$ & $100,0 \%$ & $100,0 \%$ & $100,0 \%$ & $100,0 \%$ & $100,0 \%$ \\
\hline
\end{tabular}

A maioria dos entrevistados (70\%) respondeu que desconhecia a forma como é gasta a arrecadação da conta de água e 26,1\% mostraram conhecimento. A resposta correta (operador, energia e manutenção, ou operador, energia e Central) foi respondida por $15,1 \%$ dos entrevistados, embora as respostas "Central" e "Manutenção", possam também ser consideradas corretas, e por isso leva o percentual para $26,2 \%$, pois demonstra um conhecimento sobre o sistema. A referência à CERB é pequena $(23,0 \%)$.

O desconhecimento da atividade da Central e desse tipo de saneamento foi observado também quando da coleta de dados nas secretarias municipais de saúde. Embora estas secretarias tenham um trabalho de campo com visita aos postos de saúdes das localidades, as equipes de todas as secretarias desconheciam a existência deste sistema de saneamento com fornecimento de água ininterrupto e com esgotamento sanitário e tratamento. O comentário do presidente da associação de Caém registrado na tabela 27 
refere-se a uma visita da equipe da secretaria de saúde à localidade, após a coleta de dados da pesquisa.

As equipes das secretarias de saúde têm um papel importante na promoção de hábitos sanitários na população e, nesse caso, poderiam trabalhar em conjunto com a equipe Central, principalmente com o apoio dos Agentes Comunitários de Saúde. Os resultados positivos na saúde podem ser também instrumentos para o planejamento de ações de saneamento em outras localidades do município.

As professoras das localidades, naturalmente, conhecem e utilizam o sistema de saneamento, porém em conversa com duas profissionais, foi constatado que as atividades de ensino não prevêem tópicos de educação sanitária focados no sistema de saneamento implantado.

A tabela 31 a seguir apresenta o entendimento da população a respeito do destino final dos esgotos domésticos.

Tabela 31 Destino final dos esgotos domésticos citados pela população depois da implantação do SAA e SES, segundo localidades do semi-árido baiano, 2002.

\begin{tabular}{c|c|c|c|c|c|c|c}
\hline \multirow{2}{*}{$\begin{array}{c}\text { Destino } \\
\text { Final }\end{array}$} & \multicolumn{6}{c|}{ Localidades } & \multirow{2}{*}{ Médio } \\
\cline { 2 - 6 } & $\begin{array}{c}\text { V. } \\
\text { Cardoso }\end{array}$ & Lajinha & Jacunã & Piaus & Taquari & Gameleira & \\
\hline Fossa & $54,05 \%$ & $31,25 \%$ & $32,00 \%$ & $97,06 \%$ & $100,00 \%$ & $14,00 \%$ & $48,26 \%$ \\
\hline Rede Geral & $40,54 \%$ & $56,25 \%$ & $60,00 \%$ & $0,00 \%$ & $0,00 \%$ & $84,00 \%$ & $47,09 \%$ \\
\hline Escoa na rua & $5,41 \%$ & $12,50 \%$ & $8,00 \%$ & $2,94 \%$ & $0,00 \%$ & $2,00 \%$ & $4,65 \%$ \\
\hline Total & $100,00 \%$ & $100,00 \%$ & $100,00 \%$ & $100,00 \%$ & $100,00 \%$ & $100,00 \%$ & $100,00 \%$
\end{tabular}

Todos os entrevistados informaram corretamente não haver sistema de esgotamento sanitário anteriormente ao programa da Central, porém, para a condição atual nas localidades do projeto com sistemas de esgotamento sanitário composto de rede coletora seguida de tratamento, a informação nem sempre foi a correta. Em Gameleira houve um acerto de $84 \%$ enquanto em Vila Cardoso o acerto foi de 40,54\%. Em Piaus e Taquari, onde os 
esgotos são encaminhados para fossa séptica, houve o maior percentual de acerto, $97,06 \%$ e $100 \%$ respectivamente.

É importante observar que a demanda básica da população é a implantação de um sistema de abastecimento de água, que conforme CAIRNCROSS (1993), motivada pela qualidade e pela economia por não mais comprar água de aguadeiros ou de caminhão pipa.

Neste programa de saneamento a previsão inicial era da implantação do sistema de abastecimento de água e do esgotamento sanitário sem os módulos sanitários. Estes foram incluídos posteriormente, por uma demanda da população, porém a rede de esgotamento sanitário não fazia parte da demanda natural da população, mesmo porque como o consumo de água era muito pequeno e por quase não haver instalações sanitárias, praticamente não havia também, a presença de esgotos nas ruas das localidades, não sendo assim um problema cotidiano da população local.

O conceito que a população convive em sua rotina é que as águas servidas não apresentam risco de contaminação e as águas dos sanitários sim, logo estas devem ser afastadas da residência e encaminhadas para uma caixa fechada, ficando assim, uma percepção de destinação inadequada do esgoto, quando a unidade de tratamento do sistema de esgotamento sanitário gera efluente.

Nas localidades de Piaus, Taquari os efluentes do sistema tanque séptico/weltand infiltram e evaporam a poucas dezenas de metros da estação e em Vila Cardoso e Gameleira, os proprietários das áreas vizinhas utilizam o efluente para irrigação, não havendo assim, objeções por parte da população local.

O problema resiste em Lajinha e em Jacunã. No primeiro caso, a população tem reclamado do lançamento de efluentes no rio do Aipim, embora o 
lançamento esteja dentro dos padrões legais, em ponto a jusante do local de uso da população e sua diluição no corpo receptor não causar alteração na qualidade das águas do mesmo. No segundo caso, em Jacunã, o presidente da associação de moradores relata a Lagoa de Estabilização como presença de esgoto a céu aberto.

CYNAMON (1969), advoga a necessidade de implantação de sistemas de esgotos sanitários para pequenas comunidades que já possuem sistemas de abastecimento de água, sendo necessária a institucionalização de um método de ação e comportamento que abranja desde os aspectos de promoção e mobilização das comunidades, da execução até a administração e manutenção de serviços.

Embora os resultados na saúde venham a aparecer predominantemente a médio e longo prazo, a incidência de diarréia infantil pode apresentar reduçōes em um curto espaço de tempo, podendo assim ser utilizado como um indicador dos efeitos na saúde de uma população após a implantação do programa de saneamento. Certamente a carência da condição de saneamento não é o único fator para a ocorrência desse agravo e que, portanto, deverá continuar a ocorrer, mas provavelmente, é uma frequência menor, como também as outras doenças relacionadas com água e esgoto tanto em crianças quanto em adultos.

As figuras 43 a 48 a seguir mostram os dados de diarréia em crianças menores de 2 anos nas localidades da pesquisa em período anterior $e$ posterior à implantação do SAA e do SES. Esses períodos variam em função da época de implantação do SAA e SES em cada localidade, da implantação do programa SIAB e da sua própria disponibilidade. São apresentados, para os mesmos períodos, os dados de diarréia em crianças menores de 2 anos para as demais localidades da zona rural do respectivo município, com o objetivo de comparar o comportamento das incidências de diarréia infantil nas localidades em que foram implantados os sistemas de saneamento com 
as localidades do mesmo município (cujas características físicas e sócioeconômicas são semelhantes), que não tiveram intervenção de saneamento nesse período. Desse modo tem-se uma situação anterior, em que as localidades do município tinham algum tipo de sistema de saneamento (geralmente sistema simplificado de abastecimento de água, com funcionamento precário), e, ao se modificar as condições de um grupo de localidades, se afere as alterações na saúde por meio do indicador diarréia em crianças menores de 2 anos. Os dados mensais de número de crianças de cada localidade e os números de crianças com diarréia são apresentados no Anexo E.

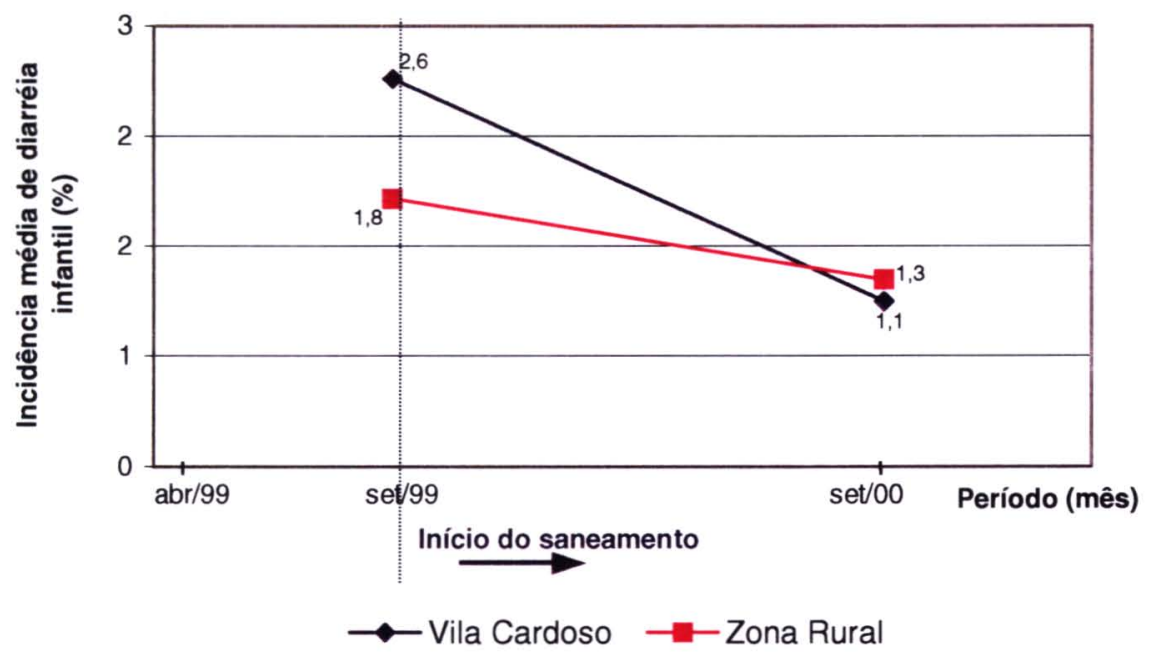

Figura 43

Incidência média anual da diarréia infantil no período de abril a setembro de 1999 (antes do saneamento) e de outubro de 1999 a setembro de 2000, em Vila Cardoso e demais localidade do município de Caém-BA.

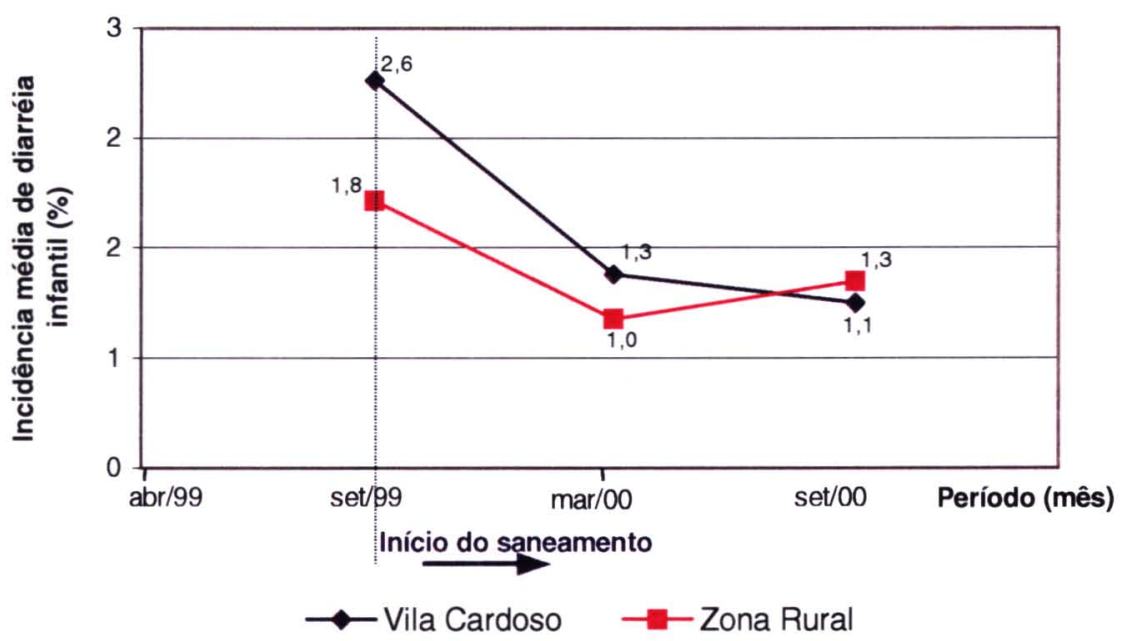

Figura 44 Incidência média semestral da diarréia infantil no período de abril de 1999 à setembro de 2000 , em Vila Cardoso e demais localidade do município de Caém-BA. 


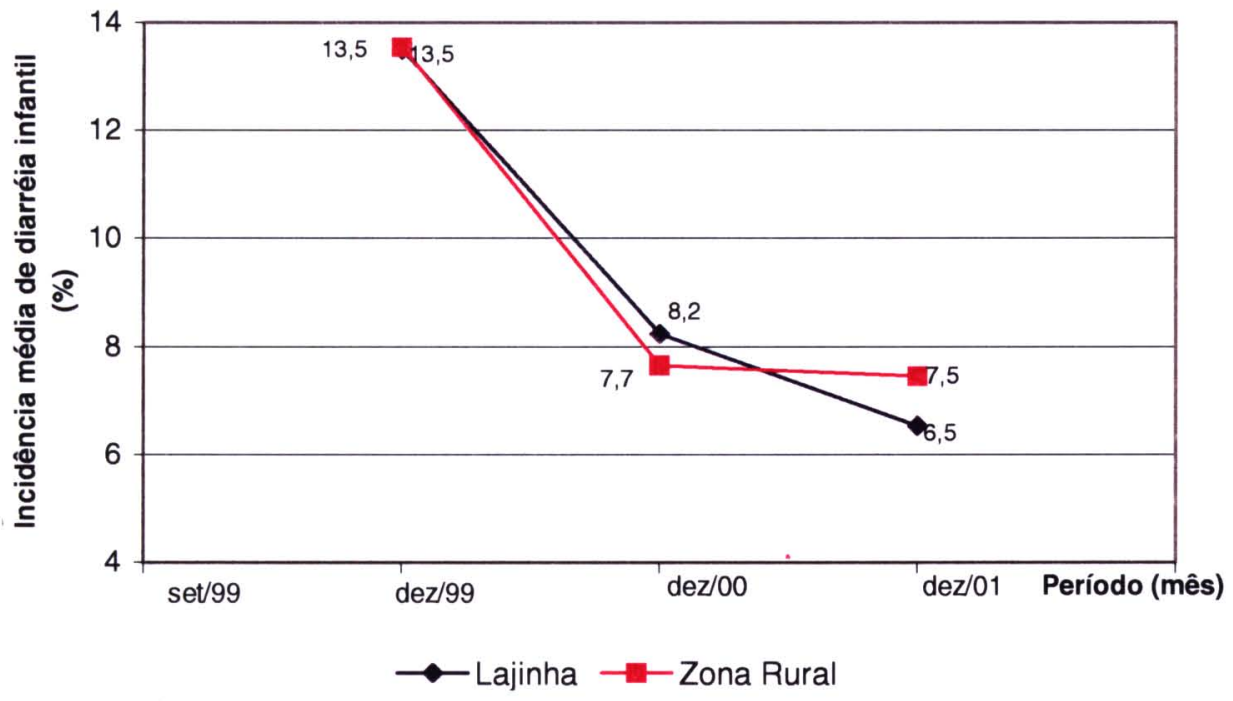

Figura $45 \quad$ Incidência média anual da diarréia infantil no período de setembro a dezembro de 1999, 2000 e 2001, em Lajinha e demais localidades do município de Pindobaçu-BA.



Figura 46 Incidência média semestral de diarréia infantil nos períodos de 2000 e 2001, em Lajinha e demais localidades do município de Pindobaçu BA. 


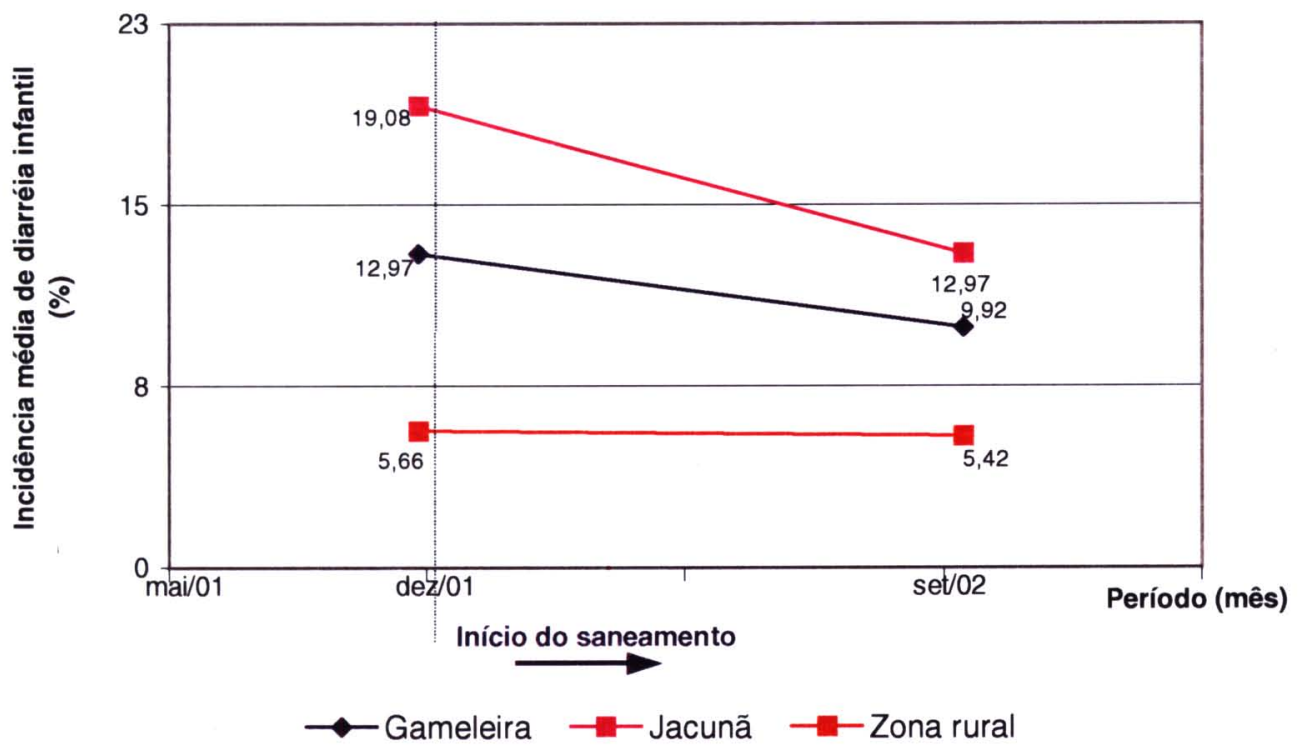

Figura 47 Incidência média anual da diarréia infantil dos períodos de maio a dezembro de 2001 e janeiro a setembro de 2002, em Gameleira, Jacunã e demais localidade do município de Jaguarari-BA.

Os resultados indicam que os valores de diarréia infantil anteriores à implantação SAA e SES são diferentes em cada localidade estudada. O acesso à água antes da implantação do SAA e SES variava em tipo, qualidade e quantidade disponível, resultando também em diferentes práticas e rotinas diárias relacionadas com a água e consequentemente com efeitos na saúde.

A localidade de Vila Cardoso possuía anteriormente um sistema composto de poço, captação por bomba e distribuição parcial para a comunidade. Nesse local os valores de redução de diarréia infantil apresentavam percentuais inferiores a $3 \%$, ao passo que nas outras localidades onde a principal fonte de água de abastecimento era superficial, com captação direta pela população, os valores excediam a $8 \%$, alcançando $19 \%$ em Jacunã.

Nesta localidade houve um decréscimo de $49,1 \%$ da diarréia infantil entre os seis meses anteriores e os seis meses posteriores à implantação do sistema enquanto nas demais localidades o decréscimo foi de $44,1 \%$. O decréscimo 
referente ao período de um ano após a implantação do sistema (outubro de 1999 a setembro de 2000) foi de $57,4 \%$, sendo o decréscimo das demais localidades de $37,0 \%$. Comparando o período de abril a setembro nas situaçōes de antes e depois do saneamento, o decréscimo das incidências média de diarréia infantil foi de $57,4 \%$ e $30,2 \%$ para Vila Cardoso e demais localidades respectivamente.

Em Lajinha, e nas outras localidades da zona rural do município, os dados disponíveis de incidência de diarréia infantil abrangem um período de 16 meses antes e de 12 meses após o início da operação do sistema de saneamento (janeiro de 2001).

Os resultados de incidência de diarréia infantil em Lajinha evidenciam os efeitos do início da entrada da atividade do PACS nessa localidade e, posteriormente, o início da entrada da operação do sistema de saneamento.

Nos primeiros 4 meses de atividade do PACS (setembro a dezembro de 1999), os valores médios de incidência de diarréia infantil para Lajinha e demais localidades eram de 13,5\%. Após 12 meses (final de 2000) os valores passam para $6,5 \%$ e $7,5 \%$. O decréscimo do valor médio de incidência de diarréia infantil em Lajinha, após o sistema de saneamento foi de $20,7 \%$, mas para as demais localidades o decréscimo foi de $2,6 \%$.

Comparando os periodos semestrais (janeiro/março, abril/junho, julho/setembro) antes e após a implantação dos sistemas encontram-se os decréscimos de $25,3 \%$ para Lajinha e $5,6 \%$ e $18,2 \%$ para as demais localidades.

Nas localidades de Gameleira e Jacunã, a coleta de dados pelo PACS/SIAB teve início em maio de 2001 e o funcionamento do sistema de saneamento em janeiro de 2002. No final do ano de 2001, antes da implantação do SAA e SES, os valores médios de incidência de diarréia infantil de ambas 
localidades eram de $13,0 \%$ e $19,1 \%$ respectivamente, superiores ao encontrado para as demais localidades da zona rural do município (6,6\%). Estes altos valores podem ser atribuídos à água utilizada pela população, escassa e provenientes de fontes não protegidas de contaminação.

Após a implantação do sistema de saneamento, os valores de incidência de diarréia infantil das duas localidades passam para 9,9\% e 13,0\% respectivamente, representando um decréscimo de $23,5 \%$ e de $32,0 \%$ para as respectivas localidades. Nas demais localidades da zona rural do município de Jaguarari o decréscimo foi de 17,4\%.

Esses valores finais de incidência de diarréia infantil, ainda altos comparados com os dados das demais localidades da pesquisa, justificamse provavelmente pelo menor período de operação do sistema de saneamento, podendo haver ainda um decréscimo nos meses seguintes.

A figura 48 a seguir apresenta os valores de incidência média de diarréia infantil para os períodos de 6 meses antes e 9 meses depois da implantação do sistema a determinação deste período deve-se ao fato de serem estes os períodos de observação comuns a todas as localidades.

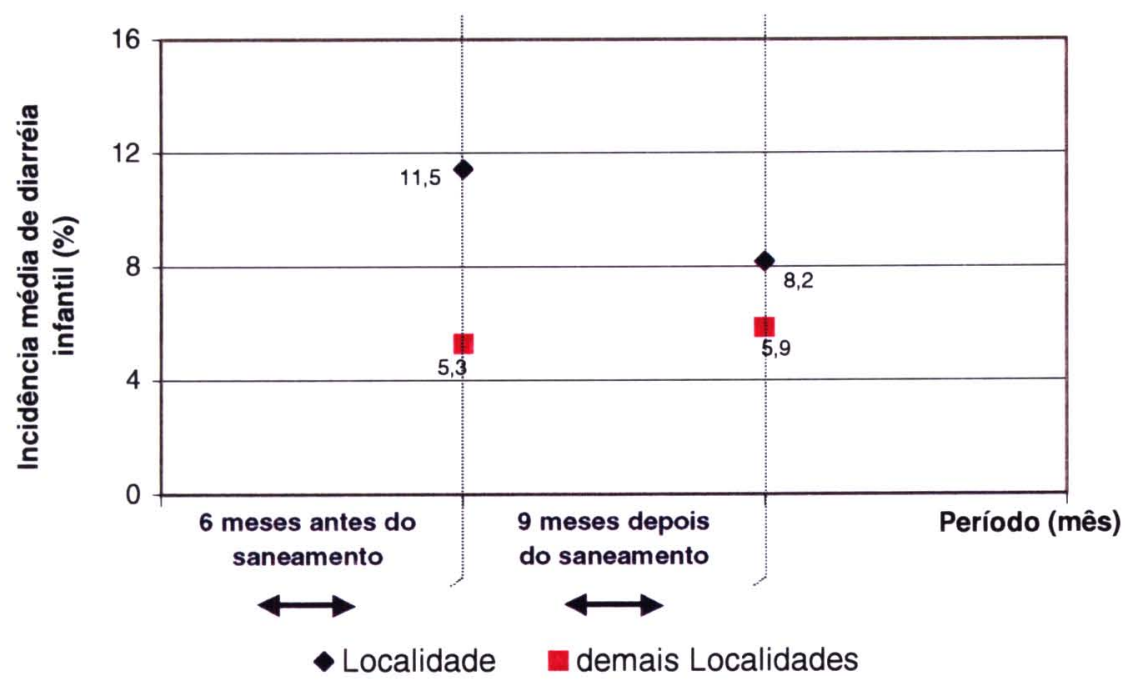

Figura 48 Incidência média de diarréia infantil nos períodos de 6 meses antes à 9 meses depois da implantação do sistema de saneamento segundo localidades das pesquisas e demais localidades das zonas rurais dos respectivos municípios. 
Para o conjunto das 4 localidades com dados disponíveis de diarréia infantil, a incidência média de diarréia infantil dos 9 meses posteriores à implantação do sistema de saneamento representa um decréscimo de $28,6 \%$ em relação à incidência média dos 6 meses anteriores à implantação do referido sistema. No conjunto das demais localidades dos respectivos municípios, houve um acréscimo de $10,6 \%$. O aumento da quantidade e melhoria da qualidade da água consumida, a disponibilidade da água sem intermitência, e as mudanças de práticas sanitárias, em especial o uso do sanitário são fatores que levam à redução da diarréia infantil, porém sendo a diarréia de origem multifatorial, outras causas podem também ter interferido positiva ou negativamente nesses resultados.

Segundo informaçōes da equipe da Secretaria Municipal, muito provavelmente, a redução do número de casos em relação ao período anterior à implantação deve ser ainda maior do que o registrado. Isto porque o sistema de coleta de informações (SIAB), ao ser iniciado em 1999, ainda não tinha a devida experiência na coleta de dados, havendo assim o subregistro de diarréia infantil como de outros agravos.

Durante a coleta de dados de diarréia infantil registrados pelo PACS/SIAB, percebeu-se que em algumas secretarias o sistema de acesso ao banco de dados se dava pelo nome da localidade (ou parte, quando havia mais de um agente para uma localidade), ou pelo próprio nome do agente de saúde. Em outros casos o sistema incluía mais de uma localidade para um mesmo agente, impossibilitando distinguir as informações de cada uma das localidades. Essas sistemáticas dificultam e às vezes impedem o uso dos dados do SIAB desagregados por localidade.

O fato também de as áreas cobertas pelos agentes comunitários não coincidirem com as zonas censitárias do IBGE impede de se fazer associações com as informações desse banco de dados. 
Uma revisão bibliográfica efetuada em 144 artigos relativa a estudos de redução de diarréia infantil atribuída a melhorias no abastecimento de água ou no esgotamento sanitário realizada por Esrey (1991) citado por HELLER (1997a, p.56), encontrou um valor médio de $20 \%$ para melhoria conjunta de água e de esgotamento sanitário.

Num estudo similar na zona rural de Bangladesh (AZIZ e col. 1990) comparando dois grupos de localidades semelhantes, onde em um dos grupos foram instaladas bombas manuais, vasos sanitários nas residências e implementadas ações de educação sanitária, foi constatada uma redução de $25 \%$ da incidência de diarréia em menores de 6 anos, em relação ao grupo de localidade em que não houve qualquer tipo de intervenção.

A simples redução da incidência de diarréia infantil pode ser um fator de melhoria para o atendimento a outros agravos. Em um Posto de Saúde (FORTES e col. 2001), verificou-se através de uma pesquisa com estudantes de medicina (futuros profissionais) que estes, tendem a priorizar o atendimento à criança em relação a um idoso. Assim, se poderia supor que num posto de saúde da região pesquisada, os profissionais tenderão a atender os pacientes infantis com doenças gastrointestinais em detrimento de idosos com doenças crônicas e degenerativas quando as doenças gastrointestinais poderiam ter sua incidência reduzida tão somente por um programa de saneamento. Segundo MARTINS (1995), o custo do tratamento de doenças relacionadas com a falta de saneamento básico, para uma população não atendida por sistema de saneamento, varia entre 33,02 US\$/habitante.ano e 79,45 US\$/habitante.ano, ao passo que para uma população atendida por sistema de saneamento este custo varia entre 10,15 US $\$$ /habitante.ano e 14,17 US $\$$ /habitante.ano.

Os resultados descritos acima se referem a uma população que corresponde a $98,2 \%$ do total de habitantes das localidades pesquisadas, visto que $1,8 \%$ 
das residências não possui ligação de água, incluindo nesse grupo, as residências recém construídas em ruas novas, onde ainda não há rede de distribuição.

Este índice de abastecibilidade (98,8\%), juntamente com o índice de inadimplência inferior a 4\%, são indicadores da aceitação da população ao sistema de saneamento implantado. Certamente o emprego de tecnologias apropriadas é um fator significativo na obtenção dos valores desses índices citados acima, pois outras localidades de porte semelhante $e^{\prime}$ sedes municipais do estado da Bahia também possuem sistemas de abastecimento de água, porém com resultados operacionais e índices de abastecimento $e$ de inadimplência diferentes dos encontrados nas localidades da pesquisa. Nos municípios brasileiros com menos de 20.000 habitantes, o percentual de domicílios conectados à rede de distribuição de água é de 46,5\% (FUNDAÇÃO IBGE 2002). No presente caso a tecnologia apropriada apresenta-se do ponto de vista dos projetos de engenharia e do modelo gerencial em que prevê a participação de população local através das associações de moradores.

No aspecto técnico, os projetos de abastecimento de água e de esgotamento sanitário previam o atendimento de $100 \%$ da população, diferentemente da prática usual de se prever um atendimento a $90 \%$ e $80 \%$ da população para o abastecimento de água e esgotamento sanitário respectivamente. Esta prática usual, baseada na meta do PLANASA, de abastecimento de água para $90 \%$ da população do País, significa no âmbito municipal, em não contemplar $10 \%$ da população do município e, no caso de esgotamento sanitário, na permanência de um ambiente insalubre com a presença de esgoto a céu aberto nas ruas e córregos não despoluídos.

A tabela 32 a seguir apresenta a população dos municípios que pertencem às localidades da pesquisa, nos anos de 1991, 1996 e 2000 e a taxa de crescimento populacional referente ao período de 1991 a 2000. 
Tabela 32 População dos municípios Caém, Jaguarari e Pindobaçu, nos anos de 1991, 1996 e 2000 e respectivas taxas de crescimento.

\begin{tabular}{|c|c|c|c|c|}
\hline \multirow[b]{2}{*}{ Município } & \multicolumn{3}{|c|}{ População } & \multirow{2}{*}{$\begin{array}{c}\text { Taxa de } \\
\text { crescimento } \\
2000 / 1991(\%)\end{array}$} \\
\hline & 1991 & 1996 & 2000 & \\
\hline Caém & 17.116 & 17.120 & 12.562 & $-3,38$ \\
\hline Jaguarari & 31.141 & 37.365 & 27.395 & $-1,41$ \\
\hline Itiúba & 34.403 & 34.804 & 35.550 & 0,37 \\
\hline Pindobaçu & 24.647 & 24.551 & 20.813 & $-1,59$ \\
\hline $\begin{array}{l}\text { Total } \\
\text { =undação । }\end{array}$ & 106.707 & 113.840 & 96.320 & $-1,13$ \\
\hline
\end{tabular}

O cálculo de população das localidades feito pela CERB em 1998 para uso nos projeto baseou-se na contagem das casas e em uma taxa de ocupação de 5 hab./res, porém muitas das residências estavam desocupadas. A taxa de ocupação encontrada na pesquisa é em média 4hab./res. Verificou-se também que esses valores não coincidem com as informações da Central referente aos números de ligações.

Assim, optou-se em se fazer uma estimativa do crescimento da população local com base no aumento número de casas construídas após a implantação do sistema, no número de ligações e no índice de adesão. Quando da visita em campo, além da observação, os presidentes das associações responderam sobre a construção de novas casas, porém em localidades como Gameleira e Jacunã, os sistemas de saneamento tinham apenas 4 meses de funcionamento, sendo um período pequeno para haver esse tipo de mudança. Nesse sentido, preferiu-se atualizar essa informação no mês de dezembro de 2002, como também o número de ligações.

A tabela 33 a seguir apresenta, para cada localidade, o número de ligações, o índice de adesão, o número estimado de casas existentes antes da implantação do sistema de saneamento, o número de casas construídas após, e a taxa de crescimento de moradias previstas. 
Tabela 33 Número de ligações, índice de adesão, total de casas, número de casas novas e taxa de crescimento de moradias, segundo localidades do semi-árido baiano, 2002.

\begin{tabular}{l|c|c|c|c|c|c|c}
\hline Localidade & $\begin{array}{c}\text { Número } \\
\text { de } \\
\text { ligações } \\
\star\end{array}$ & $\begin{array}{c}\text { Índice } \\
\text { de } \\
\text { Adesão } \\
\star \star\end{array}$ & $\begin{array}{c}\text { Total } \\
\text { de } \\
\text { casas }\end{array}$ & $\begin{array}{c}\text { Novas } \\
\text { casas }^{\star \star}\end{array}$ & $\begin{array}{c}\text { Numero de } \\
\text { casas antes } \\
\text { do sistema. }\end{array}$ & $\begin{array}{c}\text { Período } \\
\text { de } \\
\text { operação } \\
{ }^{* *} \text { (anos) }\end{array}$ & $\begin{array}{c}\text { Taxa de } \\
\text { crescimento } \\
\text { (\%) }\end{array}$ \\
\hline V. Cardoso & 382 & 98,7 & 387 & 28 & 359 & 3,3 & 2,34 \\
\hline Gameleira & 526 & 100,0 & 526 & 12 & 514 & 1 & 2,33 \\
\hline Jacunã & 233 & 96,5 & 241 & 16 & 225 & 1 & 7,10 \\
\hline Piaus & 255 & 100,0 & 255 & 12 & 243 & 2,5 & 1,95 \\
\hline Taquari & 122 & 97,0 & 1.26 & 6 & 120 & 2,5 & 1,97 \\
\hline Lajinha & 200 & 98,8 & 202 & 20 & 182 & 2 & 5,34 \\
\hline $\begin{array}{l}\text { TOTAL } \\
\text { *Fonte Presidente das Associações }\end{array}$ & $\mathbf{1 . 7 1 8}$ & $\mathbf{9 8 , 8}$ & $\mathbf{1 . 7 3 8}$ & $\mathbf{9 4}$ & $\mathbf{1 . 6 4 4}$ & & \\
${ }^{* * F o n t e ~ C e n t r a l ~}$
\end{tabular}

O crescimento populacional das localidades estimado pelo método descrito acima pode não representar com absoluta precisão o crescimento real ocorrido, porém tem-se que, em todas as localidades estudadas, o crescimento populacional foi positivo variando entre $1,95 \%$ a $7,10 \%$, ao passo que nos respectivos municípios, a taxa média de crescimento foi negativa de 1,13\%, havendo apenas o município de Itiúba que teve uma taxa de crescimento populacional positivo de $0,37 \%$.

Esses resultados indicam um grande impacto de crescimento populacional em pequenas comunidades, quando se implantam obras de infra-estrutura como as de saneamento. Usualmente a projeção de crescimento populacional é feita com base no crescimento populacional das últimas décadas associado às condições sócioeconômicas da região, sem, no entanto, incorporar o próprio sistema de saneamento como um fator modificador desta realidade.

A opção pelo tratamento de águas superficiais com Filtro Lento ao invés da estação de tratamento convencional não tem sido usualmente feita nas últimas décadas, visto que a técnica predominante segue ainda os preceitos do modelo do PLANASA. Uma estação de tratamento de água convencional 
pode vir a produzir uma água tratada com melhor qualidade, mas a um custo mais alto e requerendo condições operacionais difíceis de se garantir numa localidade pequena, como o suprimento frequente de produtos químicos, controle laboratorial e equipamentos mecanizados, cujas possibilidades de falhas podem levar a uma qualidade da água inferior à produzida por uma estação com Filtro Lento, podendo então este ser o mais eficaz para a realidade local.

As águas dos poços utilizados para abastecimento das localidades estudadas na presente pesquisa têm os seus parâmetros físicos, químicos e bacteriológicos enquadrados aos padrões de potabilidade estabelecidos pela Portaria 1.469 de 2000 do Ministério da Saúde (MS 2001) necessitando apenas de desinfecção após captação. O sistema de cloração, utilizando sal de cozinha, se apresenta também como uma alternativa tecnológica apropriada para pequenas comunidades, pois o sal, além do seu baixo custo de aquisição, é disponível em qualquer dessas localidades. Um estudo realizado pela Companhia de Saneamento do Paraná - SANEPAR, utilizando esse sistema de cloração em cinco localidades (DECONTO \& SANTOS 1995) verificou que os níveis de qualidade de água desinfetada são os mesmos dos obtidos pelos sistemas convencionais. O estudo constatou também um potencial de redução de custos de $91,2 \%$ em relação ao uso do hipoclorito de sódio.

No campo, o controle do cloro residual na rede é feito pelo método colorimétrico, pois, segundo informações da Central, seria difícil e economicamente inviável a coleta de amostra diára e o seu envio para um laboratório. A precisão deste método é menor, porém, num sistema operando com pressão positiva constante na rede, numa eventual ocorrência de um vazamento, o fluxo da água de dentro para fora reduz as possibilidades de contaminação da rede. 
A concepção do esgotamento sanitário mostra-se adequada à realidade local com o emprego de rede condominial e da opção por sistemas de escoamento exclusivamente por gravidade (sem estação de bombeamento de esgoto). O modelo condominial reduz os custos de implantação e de operação e estimula a inserção da população na implantação do sistema, reforçando a condição de associativismo e da co-responsabilidade. As reuniões para aprovação do traçado e escolha do síndico são também instrumentos de educação ambiental e de cidadania.

Os sistemas coletivos definidos como preferenciais aos individuais têm menores custos de implantação e de manutenção per capita, além de possibilitar a ligação de novas residências construídas posteriormente à implantação do sistema. $O$ uso de fossa séptica foi indicado para residências isoladas ou para as situadas em pontos baixos que demandariam a construção e a operação de uma estação elevatória.

Segundo SANTOS (1990), embora havendo uma gama de soluções técnicas de baixo custo para o abastecimento de água e de esgotamento sanitário, o fator humano reside como o principal problema para implantação das mesmas.

Os tratamentos adotados consistem em sistemas não mecanizados e de operação simples. O Tanque Imhoff requer uma baixa frequência de descarga do lodo (semestral) que é removido e transportado por caminhão próprio para um local de secagem próximo à cidade de Jacobina. $O$ Leito de Macrófitas ("wetland") após o Tanque Imhoff aumenta a remoção da matéria orgânica e dos patogênicos, alcançando eficiência de remoção de DBO superior a $80 \%$ e de coliformes fecais superior a $90 \%$, enquadrando-se à Resolução 2.288/00 do Conselho de Meio Ambiente do Estado da Bahia (CEPRAM 2000).

Quanto à Lagoa de Estabilização - utilizada na localidade de Jacunã embora haja restrição por parte da população, por conta de ser um sistema 
ao ar livre, trata-se também de uma alternativa tecnológica de tratamento apropriada para a realidade local, requerendo pouca manutenção e com baixo custo. Sua eficiência de remoção de matéria orgânica e de coliformes também atende à legislação ambiental do estado da Bahia.

Nos paises em desenvolvimento como $\circ$ Brasil, os serviços de saúde convivem tanto com doenças infecto contagiosas com maior prevalência na população de menor poder aquisitivo, quanto com as crônicas degenerativas com maior prevalência na população de maior poder aquisitivo. Do mesmo modo, a engenharia convive com a demanda de obras de infra-estrutura, cuja tecnologia apropriada caracteriza-se pelo emprego intensivo de mãode-obra e de poucos equipamentos sofisticados, e outras demandas cuja tecnologia apropriada caracteriza-se pelo uso intensivo de equipamentos e de mão-de-obra especializada. Infelizmente, esta última situação é privilegiada nos curso de engenharia, fazendo com que haja uma resistência na maior parte do corpo técnico em adotar soluções consideradas de baixo aporte tecnológico, visto que o conceito de tecnologia é geralmente associado ao alto aporte de capital, equipamento e mão-de-obra especializada.

No aspecto gerencial, a estrutura implantada pelo modelo Central II caracteriza-se pela descentralização, associativismo, auto gestão e auto sustentação financeira (no tocante à receita e despesa operacional). A descentralização da operação do sistema permite uma maior agilidade dos serviços, principalmente considerando as distâncias entre as localidades, cujo tempo de deslocamento varia entre 1 e 3 horas. Permite também uma maior possibilidade de cobrança dos moradores pela qualidade do serviço, já que o operador é também um morador da localidade. A descentralização de parte do serviço para a associação representa ao mesmo tempo a coresponsabilidade, pois esta, por ser filiada à Central, tanto tem direitos quanto obrigações, fazendo com que a sua atuação na Assembléia Geral 
seja comprometida com os interesses da localidade, mas dentro das reais possibilidades técnicas e econômicas.

Essa estrutura é semelhante ao modelo existente no estado do Ceará denominado SISAR (SCHWEIZER e NIERADTKA 2001), também implantado através de um convênio com o mesmo banco alemão é vinculado à Companhia de Águas e Esgoto do Ceará - CAGECE, empresa estatal concessionária dos serviços de água e de esgoto; no caso da Central, tratase de uma sociedade civil, cujo conselho administrativo é majoritariamente formado por presidentes das associações de moradores das localidades.

No caso do SISAR, há uma delimitação do seu campo de atuação que se restringe a comunidades com população de até 1.000 habitantes, que, segundo a CAGECE, seriam deficitárias se fossem operadas pelo modelo convencional da empresa. A política de modelo de saneamento fica nesse caso definida de modo que, onde há possibilidade de lucro, a empresa (estatal, ainda) assume a responsabilidade total pela implantação, operação e manutenção e onde não há possibilidade de lucro adota-se um modelo de co-gestão.

O modelo da Central não tem essa limitação, possibilitando assim a incorporação de localidades de maior população e viabilizando o funcionamento de sistemas de saneamento naquelas de menor porte. A abrangência de uma maior população atendida possibilita também o rateio das despesas de operação por uma maior número de consumidores o que possibilita a redução da tarifa ou pelo menos uma amortização da elevação de outros custos como o da energia elétrica, combustível e mão-de-obra.

O modelo da SISAR apresenta a vantagem de ter claramente uma definição do gestor desse modelo. No caso da Bahia, a gestão é feita em parte pela CERB e em parte pela Secretaria de Infra Estrutura, não havendo uma gestão institucionalizada que pudesse centralizar as ações de manutenção e 
ampliação desse modelo em consonância com os planos e programa de saneamento do governo, em que também está incluída a EMBASA, concessionária da maioria dos municípios do Estado.

De acordo com a metodologia utilizada pelo PMSS (IPEA 2001) para avaliação dos serviços de água e esgoto, o sistema de abastecimento de água com paradas ocasionais, e não de manobras, na rede de distribuição pode ser considerado como de fornecimento ininterrupto, pois as paradas referem-se apenas à manutenção. Nesta classificação, encontram-se 33,7\% dos sistemas de abastecimento de água operados por instituições municipais e $22,1 \%$ dos sistemas operados por empresas estaduais. A constância do fornecimento de água pela rede de distribuição estimula o hábito do consumo e paulatinamente a população reduz a prática de acumular água em vasilhames que, além do desperdício, da falta de conforto e da pouca higiene que propicia, é, atualmente, um dos focos mais comuns da larva do Aedes aegypti. 


\section{CONCLUSÕES E RECOMENDAÇÕES}

O estudo realizado em localidades do semi-árido baiano após a implantação de um sistema de saneamento associativo, constituído de abastecimento de água com distribuição domiciliar e hidrometração e de esgotamento sanitário composto de rede coletora e tratamento de módulos sanitários nas residências, aponta mudanças significativas dos hábitos sanitários da população. Tais mudanças evidenciam-se pela associação inversa com o indicador incidência de diarréia infantil, pelo aumento da renda local e pela melhoria no valor econômico dos imóveis, bem como promovem o fortalecimento e o crescimento das atividades das associações de moradores locais, incentivando a participação social, reduzindo os fatores de risco à saúde e melhorando as condições de vida da população.

A população das localidades estudadas incorporou novas práticas sanitárias relacionadas com o uso da água, tais como: adequação do armazenamento e tratamento dado à água no domicílio; adequação do local de lavagem das mãos, alimentos e roupas; e regularidade na prática do uso de vaso sanitário, que passou a ser utilizado pela quase totalidade da população estudada. Uma parcela de $43,5 \%$ dessa população ainda utiliza água para beber proveniente de outras fontes que não do sistema implantado, sendo que $20,5 \%$ deste percentual provêm da coleta de água de chuva. Após a implantação dos sistemas de saneamento, a frequência das práticas sanitárias inadequadas no domicílio decresceu de $30,2 \%$ para $5,2 \%$ ao passo que a frequência das práticas sanitárias adequadas cresceu de $27 \%$ para $70 \%$.

A maior percepção que a população apresenta dos benefícios em saúde diz respeito a aspectos corporais e posturais. A população relata como maior agravo de saúde associado à falta da água as dores nas costas, devido ao transporte de vasilhames d'água na cabeça e à postura corporal inadequada, ao lavar roupas e utensílios em bacias colocadas no chão. A 
diarréia, dor de barriga e doenças de pele são também relatadas como doenças relacionadas com a falta de água.

Nas localidades onde foram implantados os sistemas de saneamento estudados, houve um decréscimo de $28,6 \%$ na incidência média de diarréia infantil (crianças menores de 2 anos), ao passo que, nas demais localidades do município, onde o quadro de infra-estrutura de saneamento não sofreu alteraçōes, o acréscimo da incidência média de diarréia foi de $10,6 \%$. Embora esses valores não possam ser atribuídos exclusivamente ao saneamento, pois a diarréia infantil possui causas multifatoriais, ficam evidentes os efeitos da implantação de um sistema de saneamento do modelo estudado na saúde infantil, especialmente ao se comparar com localidades que permaneceram com os seus sistemas de saneamento existentes, independentemente do seu modelo tecnológico, abrangência e eficácia.

As ações do PACS existentes nas localidades estudadas também promovem a redução da incidência de diarréia infantil, mediante o acompanhamento periódico pelo agente comunitário de saúde, implementando ações curativas e preventiva de saúde, porém seu alcance é limitado, reduzindo os valores da incidência de diarréia a um patamar que, para ser ultrapassado, necessita associar-se a outras intervenções em promoção de saúde, como, por exemplo, a implantação e/ou melhoria dos serviços de saneamento local ora analisado.

O sistema de saneamento implantado, com fornecimento domiciliar de água ininterrupto sob pressão, estimula a construção e melhoria das instalações hidráulicas prediais, destacando-se como prioritária a instalação do tanque de lavar roupa e da pia de cozinha.

A valorização do patrimônio decorrente da implantação do sistema de saneamento foi também um fator de estímulo para a melhoria das 
instalações prediais que passam a agregar 0 valor do investimento ao patrimônio.

Nas localidades estudadas, a demanda por moradia resultou na ocupação das casas disponíveis, na construção de novas casas e no acréscimo do valor de venda e de aluguel dos imóveis em percentuais de $50 \%$ a $100 \%$, demonstrando uma maior atratividade pela localidade tanto pela mudança de pessoas oriundas de outros povoados que não foram contemplados com sistema de abastecimento de água, quanto pelo retorno de antigos moradores, que haviam migrado para cidades maiores e retornam na condição de aposentados, contribuindo para o acréscimo da renda local. As taxas de crescimento populacional das localidades estudadas, após dois anos de implantação do sistema de saneamento, variaram entre 1,95\% e $7,10 \%$ ao ano. Nos respectivos municípios, essas taxas variaram entre $3,38 \%$ e $0,37 \%$ sendo o valor médio de $-1,13 \%$.

Programas dessa natureza, viabilizados principalmente no nordeste brasileiro, poderiam favorecer uma maior fixação do homem ao local de origem, bem como a volta dos que migraram para os grandes centros urbanos buscando melhores condições de vida, diminuindo assim, certas condições de miséria. O impacto na localidade e nos centro urbanos, resultaria em melhoria na qualidade de vida em ambas as situações.

A população costumava despender aproximadamente 1 hora e 20 minutos por dia para a tarefa de transporte de água para suas residências. Em períodos de seca, em que se comprava água distribuída por caminhão pipa, o custo do metro cúbico da água era de R\$160 por $10 \mathrm{~m}^{3}$. Atualmente o custo do metro cúbico de água potável canalizada é de $R \$ 6,50$ e $R \$ 8,50$, dependendo da localidade, valores estes compativeis com a possibilidade de pagamento dos moradores locais. $O$ consumo de água per capita aumentou de 23L/hab.dia para 69L/hab.dia. Essa nova situação representa um aumento do conforto em decorrência de não mais necessitar de transportar a 
água da fonte para a casa, proporcionando uma maior disponibilidade de tempo tanto para atividades de trabalho quanto de lazer e cuidados com os filhos, reduzindo o risco de acidentes com crianças. A redução do custo da água representa também uma economia na despesa familiar e como consequência mais direta 0 aumento do consumo de uma água sanitariamente segura reduzindo os riscos à saúde.

O fortalecimento das associações de moradores, necessário para a operação dos sistemas de saneamento implantados tem estimulado essas associações ao desenvolvimento de novas ações comunitárias participativas, voltadas para a melhoria de oportunidades de emprego, para a discussão dos problemas locais, levando a medidas concretas como a coleta e destinação final do lixo doméstico, o lazer, o apoio aos associados em soluções de problemas de saúde e de aposentadoria, contribuindo assim para o exercício da cidadania e da participação social.

Na região, o modelo Central tem a sua ação ainda de forma segmentada, atrelada apenas ao setor saneamento, havendo pouco relacionamento com os setores saúde e educação. A inter-relação desses setores seria de fundamental importância para a saúde pública, o que poderia promover ações conjuntas dentro de uma visão mais ampla de prevenção de riscos e promoção da saúde, com o objetivo de reduzir os fatores de risco à saúde e provocar melhoria da qualidade de vida das populações, e o próprio fortalecimento e expansão do modelo Central na região.

Outro aspecto a ser assinalado é a existência de macro e micro medição do consumo de água na totalidade das ligações domiciliares, o que possibilita um melhor conhecimento do consumo de água per capita e as suas variações diárias e sazonais podendo assim se obter informaçōes que possam ser utilizadas em futuros projetos de saneamento evitando 0 emprego de valores padrōes estabelecidos pela Norma Brasileira, nem sempre condizentes com as realidades regionais. 
As estruturas dos sistemas de abastecimento de água e de esgotamento sanitário implantados pela Central II apresentaram um custo de implantação inferior a $\mathrm{R} \$ 234,00$ por habitante, sendo adotadas técnicas construtivas modelos operacionais que possibilitam o uso da mão-de-obra local. As unidades de tratamento de água não requerem consumo de produtos químicos e o sistema de desinfecção requer apenas a compra de sal de cozinha, que é disponível nas próprias localidades. Os sistemas têm sido capazes de manter o fornecimento ininterrupto de água, com paradas de manutenção, conquistando a confiança da população sobre o aspecto de qualidade e de disponibilidade da água. Fatores como esses fazem com que estas estruturas sejam consideradas como de tecnologia apropriada à realidade sócioeconômica ambiental da região.

O sistema de esgotamento sanitário também se apresentou como um modelo de tecnologia apropriada a esta realidade. Os sistemas de coleta, transporte e tratamento não possuem equipamentos eletro - mecânicos e a operação e a manutenção são feitas de forma simples com a mão-de-obra local. Esses modelos simples de tratamento apresentam eficiência de remoção da matéria orgânica de $80 \%$ e de organismos patogênicos da ordem de $90 \%$, encontrando-se em acordo com a legislação ambiental.

O modelo operacional da Central, em que as comunidades são co-gestoras e também beneficiadas pelos sistemas de saneamento, possibilita aos afiliados assumirem uma ação responsável e compatível com a sua realidade. O modelo gerencial e operacional implantado, com a descentralização da operação é um fator positivo, e a atribuição da operação às associações de moradores locais uma forma inédita e adequada que se mostrou viável nas localidades da região do semi-árido baiano.

Este modelo, diferente do comumente adotado na operação de sistemas de saneamento, mas que tendo como objetivo principal a melhoria da infra- 
estrutura do saneamento, mostrou-se também importante, necessário, sintonizado com a tecnologia utilizada nas estruturas de saneamento e adequado para o estímulo da cidadania com valorização econômica e social das localidades.

No caso do saneamento rural, além da necessidade de se verificar as tecnologias apropriadas para a condição específica, deve-se ter também atenção às diferenças do que representa a implantação de uma obra de saneamento num centro urbano e na zona rural. A implantação de serviços de saneamento em um novo bairro de uma cidade é vista como um tópico da infra-estrutura como telefonia, transporte público, etc., em que a população tem previamente um entendimento do seu uso nos moldes em que é implantado. No caso da zona rural, em que a população convive com a pouca água disponibilidade de água e que seus hábitos estão adaptados a essa escassez, a implantação do saneamento deve ser feita levando em conta essa realidade para que se possa alcançar objetivos positivos. Para isso é necessária uma atenção ao viés urbano, característica da maioria das pessoas responsáveis por intervenções na zona rural.

Os resultados dessa pesquisa com relação aos benefícios diretos e indiretos adquiridos pela população decorrentes da implantação de um sistema de saneamento sintonizam com resultados encontrados em outros estudos. MARA (2000) relata o fato de que aproximadamente 360 a 400 bilhões de dias de trabalho foram perdidos na África, Ásia e América Latina devido a doenças relacionadas a água e excreta. As melhorias em saneamento e higiene poderiam ter aumentado o PIB em até 49-54\%. Independentemente destes valores, torna-se claro que a economia do mundo em desenvolvimento é seriamente afetada por investimentos inadequados em saneamento e higiene.

Assim sendo, após o desenvolvimento dessa investigação é recomendável que: 
Seja dada continuidade aos estudos relativos à avaliação da alteração das condições de saúde da população atendida pelos sistemas de saneamento estudados, utilizando-se, além da diarréia infantil, de outros indicadores como a prevalência de verminose e um aprofundamento do estudo dos efeitos, a longo prazo, na coluna vertebral das mulheres e crianças da comunidade que antes desenvolviam práticas associadas ao transporte de vasilhas de água na cabeça e às posições ocupacionais inadequadas.

Seja reforçado o processo de educação ambiental desenvolvido na comunidade, para estimular o aumento da preferência pelo uso da água distribuída pela Central para abastecimento, como também o uso do esgoto tratado para irrigação controlada, dada à baixa pluviosidade da região. Considerando-se esta como uma ação ambientalmente apropriada porque otimiza os recursos utilizados para a captação da água, e promove ó retorno da matéria orgânica ao solo, que, ao invés de poluir os corpos d'água retorna para o solo e o fertiliza.

Sejam realizados estudos de acompanhamento da eficiência e da qualidade operacional das unidades implementadas e consideradas como de tecnologia apropriada, tais como a estação de tratamento de água por Filtro Lento, a desinfecção por eletrólise, o ramal condominial de esgotamento sanitário e a estação de tratamento por Tanque Imhoff e "Wetland", as quais, embora freqüentemente preconizadas como soluções indicadas para a realidade da região, não têm sido adotadas nos projetos de saneamento.

Haja uma maior inserção e discussão do conceito de tecnologia apropriada nos cursos de saneamento das diversas formações profissionais.

Sejam efetuados estudos da variaçāo sazonal e diária de consumo de água utilizando sistemas da Central, dado que estes sistemas possuem macromedição e micromedição na totalidade das suas ligações, o que 
possibilita delimitar valores desses coeficientes de variação de vazão em acordo com a realidade da região.

Seja feita uma divulgação dos resultados alcançados pela implantação desses sistemas de saneamento e a busca de parcerias de trabalho com as secretarias municipais de saúde e de educação, no sentido do desenvolvimento de ações integradas voltadas para a mudança de hábitos sanitários da população e para a melhoria das condições de vida local.

Sejam feitos ajustes metodológicos no $\mathrm{PACS} / \mathrm{SIAB}$, em relação à delimitação e nomenclatura das micro-áreas, para que estas possam ser associadas às zonas censitárias do IBGE de modo que seja possível a agregação de informação do dois bancos de dados e que se possa também obter informações das localidades diretamente dos bancos de dados e não apenas os dados globais do município.

Haja uma maior divulgação deste tipo de sistemas junto às comunidades da região, com o objetivo de aumentar o número de comunidades filiadas, garantindo a sua sustentabilidade econômica e operacional a longo prazo.

Seja feito um acompanhamento durante e depois da implantação de programas de saneamento com o objetivo de avaliar as vantagens $e$ desvantagens para um aperfeiçoamento constante dos métodos gerenciais e das tecnologias utilizadas, atualizando e verificando a sua real adequação.

Seja feita a regulamentação, pelo governo do estado, desse tipo de sistema de saneamento dentro da sua política de saneamento e/ou dos seus programas de saneamento, saúde e desenvolvimento regional, possibilitando assim maior garantia da continuidade e replicabilidade em outros locais, respeitadas as devidas adaptações. 


\section{REFERÊNCIAS BIBLIOGRÁFICAS}

1. [ABNT] Associação Brasileira de Normas Técnicas. NBR-7229: projeto, construção de sistemas de tanques sépticos. Rio de Janeiro; 1993.

2. [ABNT] Associação Brasileira de Normas Técnicas. NBR-12216: Projeto de estação de tratamento de água para abastecimento público. Rio de Janeiro; 1992.

3. [ABNT] Associação Brasileira de Normas Técnicas. NBR-12217: Projeto de reservatório de água para abastecimento público. Rio de Janeiro; 1994a.

4. [ABNT] Associação Brasileira de Normas Técnicas. NBR-12218: Projeto de rede de água para abastecimento público. Rio de Janeiro; 1994b.

5. [ABNT] Associação Brasileira de Normas Técnicas. NBR-13969: Tanques sépticos - Unidades de tratamento complementar e disposição final dos efluentes líquidos - Projeto, construção e operação. Rio de Janeiro; 1997.

6. Almeida Filho N, Rouquaryol $M Z$. Introdução à epidemiologia moderna. Rio de Janeiro: ABRASCO; 1990.

7. Almeida Filho N, Rouquaryol M Z. Epidemiologia e saúde. $5^{a}$ ed. Rio de Janeiro: Editora Médico e Científica Ltda.; 1999; p. 5.

8. [Anonymus]. Rio Grande do Sul fornece esgoto para irrigação. Rev Bio. 2001; 11(18): p33. 
9. Andrade Neto CO. Uma solução eficaz e de baixo custo para o esgotamento sanitário urbano. Rev Engenharia Sanitária e Ambiental. 1985; 2(24): $239-241$.

10. Andrade Neto CO. Participação da comunidade na implantação e na operação de sistemas de esgotos. Anais do $20^{\circ}$ Congresso Brasileiro de Engenharia Sanitária e Ambiental; 1999 mai 10 -14; Rio de Janeiro - Brasil. Associação Brasileira de Engenharia Sanitária e Ambiental; 1999. 10p.

11. Azevedo Netto J M de. Tanques sépticos: conhecimentos atuais. Rev Engenharia Sanitária e Ambiental. 1985. 2: 222 - 229.

12. Azevedo Netto JM de. Aproveitamento de águas de chuva para abastecimento. Rev Bio. 1991; abr/jun: 44-48.

13. Azevedo Netto J M. Tecnologias innovadoras $Y$ de bajo costo utilizadas en los sistemas de alcantarillado. Washington, D.C: Organizacion Panamericana De La Salud; 1992.

14. Aziz KM, Bilquis AH, Hasan KhZ, Patwary MY, Huttly SR, Rahaman MM et al. Reduction in diarrhoeal diseases in children in rural Bangladesh by environmental and behavioural modifications. Transactions of the Royal Society of Tropical Medicine and Hygiene. 1990; 84(3): 323466.

15. Barros RTV, Chernicharo CAL, HELLER I, Von Sperling $M$, editores. Manual de saneamento e proteção ambiental para os municípios. Belo Horizonte: Escola de Engenharia da UFMG; 1995. v.2.

16. Brasil. Constituição da República Federativa do Brasil. Brasília: Senado Federal, Centro Gráfico; 1988. 
17. Brasil. Código de Defesa do Consumidor: lei no 8.078 de 11/09/1990. Brasília: Senado Federal, Centro Gráfico; 1990.

18. Britto N, Lima NT. Saúde e nação: a proposta do saneamento rural: um estudo da Revista Saúde (1918 - 1919). In: Estudos de História e Saúde 3, Rio de Janeiro: 1991. p.1-33.

19. Burger SE, Esrey SA. Water and sanitation: health and nutrition benefits to children. In: Andersen $P$ et al. Child growth and nutrition in developing countries: priorities for action. Ithaca NY: Pinstrup; 1995. 153-175.

20. Cairncross S, Feachem RG. Environmental health engineering in the tropics. $2^{\mathrm{a}}$ ed. London: John Wiley \& Sons, 1993.

21. Cairncross S. Modelos conceituais para a relação entre a saúde e o saneamento básico. In: Heller L. et al., organizadores. Saúde e saneamento em países em desenvolvimento. Rio de Janeiro: CC\&P Editores Ltda; 1997. 169 - 219.

22. Carvalho FM, Cruz M, Mathias C, Matos MAA, Pereira PMS, Orrico SRM et al. Diarréia aguda e contaminação da água. Rev Bio. 1990; jul/set: $45-47$.

23. [CEI] Centro de Estatística e Informação. Riscos de seca na Bahia: Salvador: CEI. 1991; v.2. (séries especiais CEI 2).

24. [CEI] Centro de Estatística e Informação. Informações básicas dos municípios baianos - Piemonte da Diamantina. Salvador: CEI. 1994. v.12. 
25. [CEPRAM] Conselho Estadual do Meio Ambiente. Resolução no 2288 de 28 de abril de 2000. Estabelece os padrões de lançamento para efluentes sanitários nos corpos hídricos situados na Região Metropolitana de Salvador - RMS e demais municípios do Estado da Bahia, gerados a partir da implantação de empreendimentos imobiliários habitacionais (NT-002/2000). Diário Oficial do Estado da Bahia. Salvador, 03 mai 2000.

26. [CERB] Companhia de Engenharia Rural da Bahia. Relatório de impacto ambiental da barragem de Ponto Novo. Salvador: CERB; 1996.

27. [CERB] Companhia de Engenharia Rural da Bahia. Projeto executivo de abastecimento de água de Vila Cardoso, município de Caém. Salvador: CERB; 1998a.

28. [CERB] Companhia de Engenharia Rural da Bahia. Projeto executivo de abastecimento de água de Gameleira e Jacunã, município de Jaguarari. Salvador: CERB; 1998b.

29. [CERB] Companhia de Engenharia Rural da Bahia. Projeto executivo de abastecimento de água de Taquari e Piaus, município de Itiúba. Salvador: CERB; 1998c.

30. [CERB] Companhia de Engenharia Rural da Bahia. Projeto executivo de abastecimento de água de Lajinha, município de Pindobaçu. Salvador: CERB; 1998d.

31. [CERB] Companhia de Engenharia Rural da Bahia. Projeto executivo de esgotamento sanitário de Lajinha, município de Pindobaçu. Salvador: CERB; 1998 e. 
32. [CERB] Companhia de Engenharia Rural da Bahia. Perfil sócio econômico da população das localidades do Programa Saneamento Bahia II. Salvador: CERB; $1998 f$.

33. [CERB] Companhia de Engenharia Rural da Bahia. Projeto executivo de esgotamento sanitário de Vila Cardoso, município de Caém. Salvador: CERB; 1999a.

34. [CERB] Companhia de Engenharia Rural da Bahia. Projeto executivo de esgotamento sanitário de Piaus e Taquari, município de Itiúba. Salvador: CERB; 1999b.

35. [CERB] Companhia de Engenharia Rural da Bahia. Projeto executivo de esgotamento sanitário de Gameleira, município de Jaguarari. Salvador: CERB; 2000a.

36. [CERB] Companhia de Engenharia Rural da Bahia. Projeto executivo de esgotamento sanitário de Jacunã, município de Jaguarari. Salvador: CERB; 2000b.

37. [CETESB] - Companhia de Tecnologia de Saneamento Ambiental: Técnica de abastecimento e tratamento de água. $2^{\mathrm{a}}$ ed. São Paulo: CETESB, 1977; v.2.

38. Chioro A, Almeida ES, Zioni F. Políticas públicas, organização do sistema de saúde antecedentes da reforma sanitária e do SUS. São Paulo; 1997. [Texto didático - Faculdade de Saúde Pública da USP].

39. Chernicharo CA de L. Princípios do tratamento biológico de águas residuárias - Reatores anaeróbios. Belo Horizonte: Departamento de Engenharia Sanitária e Ambiental - UFMG, 1997. v.5. 
40. Conroy, R. M., Meegan, M. E., Joyce, T., McGuigan, K., Barnes, J. Solar disinfection of water reduces diarrhoea disease: an update. [publicação on line]. Archive of Disease Childhood. London: 1999. Disponivel <URL: http://www.archdischild.com>. [30 abr 2002].

41. Cynamon SE. Procedimentos para equacionamento e projetos de esgotos sanitários de pequenas comunidades. São Paulo: 1969. [Tese de Doutoramento - Faculdade de Saúde Pública da USP].

42. Cynamon SE. Sistema não convencional de esgotos sanitários a custo reduzido para pequenas coletividades e áreas periféricas. $2^{\mathrm{a}}$ ed. Rio de Janeiro: Escola Nacional de Saúde Pública; 1987.

43. D'Aguila P S, Roque O C, Miranda C A, Ferreira A P. Avaliação da qualidade de água para abastecimento público do Município de Nova Iguaçu. Cad. Saúde Pública, Rio de Janeiro. 2000; 16 (3): 1 - 11.

44. Deconto L, Santos JCR. Produção de desinfetantes "in loco" Experiência da SANEPAR. SANARE Revista Técnica da SANEPAR, Curitiba. 1995; 4(4): 15-21.

45. Dias MG. Frutos Mirrados. Rev Bio. 1994; 2: 7 - 10.

46. Dias MFS, Araújo DRSM. O uso de pedra de enxofre para conservação da qualidade da água em reservatórios domiciliares Projeto de Pesquisa. Feira de Santana; 1997.

47. Ennes YM. Contribuição à memória do saneamento rural em Minas operacionalização dos programas estaduais. Rev Bio. 1990; 4: 50 - 59.

48. Ennes YM. O saneamento no Brasil, repassado à luz da tecnologia apropriada. Rev Mineira de Engenharia. 1989; 6(3): 13- 16. 
49. [EPA] Environmental Protection Agency. Manual wastewater treatment / disposal for small communities. Washington (DC): EPA, 1992.

50. Fortes P, Zoboli ELCP, Spinetti S. R. Critérios sociais na seleção de pacientes em serviços de emergência. Rev Saúde Pública. 2001; 35(5) 451-455.

51. Freitas ICC de, Peçanha JEM, Heller L. Considerações quanto ao emprego da "avaliação de impacto sobre a saúde-ais" às ações de saneamento. Anais do IV Simpósio Luso Brasileiro de Engenharia Sanitária e Ambiental. 1990 dez 9 - 13; Minas Gerais, Brasil. Belo Horizonte: Associação Brasileira de Engenharia Sanitária e Ambiental; 1990. 22p.

52. Fundação IBGE. Informações básicas sobre municípios. [publicação on line]. Fundação IBGE. Rio de Janeiro: 2001. Disponível <URL: http://www.ibge.net/cidadesat/default.php>. [03 jul 2002].

53. Fundação IBGE. Pesquisa Nacional de Saneamento Básico: 2000. Rio de Janeiro; 2002.

54. Getaneh T, Assefa A, Tadesse Z. Diarrhoea Morbidity in an Urban Area of Southwest Ethiopia. The East African Medical Journal. 1997; 74, 8: $491-494$.

55. Guimarães ASP. O planejamento e saneamento de baixo custo: o exemplo do esgotamento. In: Anais do Seminário de Habitação para População de Baixa Renda; 1987 set 14 - 18; Rio Grande do Norte, Brasil. Natal: Ministério do Desenvolvimento Urbano e Meio Ambiente; 1987. 16p. 
56. Günther WMR, Ribeiro H. Saneamento ambiental e promoção da saúde a partir da educação em pequenas comunidades do estado de São Paulo. Anais do 22ㅇ Congresso Interamericano de Engenharia Sanitária e Ambiental. $2000 \mathrm{dez} 16$ - 20; Porto Alegre - Brasil. Associação Brasileira de Engenharia Sanitária e Ambiental; 2000. 7p.

57. Harbel R, Green MB, Cooper PF, Brix H, Vymazal J. Constructed wetlands for wastewater treatment in Europe. Leiden: Backhuys Publishers, 1998.

58. Heller L. Saneamento e saúde. Brasília: OPAS/OMS; 1997a.

59. Heller L. Moraes LRS, Monteiro TC do N, Salles MJ, Almeida LM de, Câncio J, et al. Saúde e saneamento em países em desenvolvimento. Rio de Janeiro: CC\&P Editores Ltda; $1997 \mathrm{~b}$.

60. [IPEA] Instituto de Pesquisa Econômica e Aplicada. Sistema Nacional de informações sobre saneamento (SNIS) - Diagnóstico dos serviços de água e esgotos 2000. [publicação on line]. IPEA. Brasília: 2001. Disponível <URL: http://www.snis.gov.br>. [15 out 2002].

61. Jordão, EP, Pessoa CA. Tratamento de esgoto doméstico. $3^{\mathrm{a}}$ ed. Rio de Janeiro: ABES, 1995.

62. Kiyu A, Hardin S. Latrine use in rural Sarawak, Malaysia. The Southeast Asian Journal of Tropical Medicine and Public Health. 1993; 24(1): $40-42$.

63. Lima AS, Bernardes RS. Levantamento epidemiológico das condições sanitárias da água para abastecimento público na cidade de Redenção (PA). Anais do 21ํ Congresso Brasileiro de Engenharia Sanitária e 
Ambiental. 2001 set 16 - 20; João Pessoa - Brasil. Associação Brasileira de Engenharia Sanitária e Ambiental; 2001. 4p.

64. Lopes J. Argolo SN, Couto DP, Jesus IOM de et al. Participação comunitária e educação sanitária como fatores de implementação de ações de saneamento básico no meio rural. Anais do $18^{\circ}$ Congresso de Engenharia Sanitária e Ambiental. 1995 șet 17 - 21; Salvador Brasil. Associação Brasileira de Engenharia Sanitária e Ambiental; 1995. $11 \mathrm{p}$.

65. Mahmud MA, Chappell C, Hossain MM, Habib M, Dupont HL. Risk factors for development of first symptomatic Giardia infection among infants of a birth cohort in rural Egypt. The American Journal of Tropical Medicine and Hygiene. 1995; 53, 1: 84-88.

66. Mara D. Saneamento em países de desenvolvimento: uma nova perspectiva para o novo milênio. Rev Engenharia Sanitária e Ambiental. 2000; 5(3 e 4): $109-111$.

67. Mara D, Feachen R. Aspectos técnicos de saúde pública no planejamento de programas de saneamento a baixo custo. Rev Engenharia Sanitária, Rio de Janeiro: 1981; 20(1): 85 - 92.

68. Martins G. Benefícios e custos do abastecimento de água e esgotamento sanitário em pequenas comunidades. São Paulo; 1995. [Dissertação de Mestrado - Faculdade de Saúde Pública da Universidade de São Paulo].

69. Melo JCR de. Sistemas condominiais de esgotos. Rev Engenharia Sanitária e Ambiental. 1985; 2(24): 237 - 238. 
70. Minayo MCS. O desafio do conhecimento: pesquisa qualitativa em saúde. $7^{a}$ ed. São Paulo: Hucitec; Rio de Janeiro: Abrasco; 2000.

71. [MMA] Ministério do Meio Ambiente, dos Recursos Hídricos e da Amazônia Legal / Associação Brasileira de Educação Agrícola Superior. Cisterna de placas, que danado é isso? Manual de construção. Brasília; 1998 [Cartilha do III Programa de Suporte Técnico à Gestão de Recursos Hídricos].

72. Moraes LRS. Avaliação do impacto sobre a saúde das ações de saneamento ambiental em áreas pauperizadas de Salvador - projeto AISAM. In Heller $L$ et al., organizadores. Saúde e saneamento em países em desenvolvimento. Rio de Janeiro: CC\&P Editores Ltda.; 1997. p. $281-305$.

73. Moraes LRS, Borja PC, Tosta CS. Qualidade de água da rede de distribuição e de beber em assentamento periurbano: estudo de caso. Anais do 20 Congresso Brasileiro de Engenharia Sanitária e Ambiental; 1999 maio 10 -14; Rio de Janeiro - Brasil. Associação Brasileira de Engenharia Sanitária e Ambiental; 1999. 11p.

74. Moraes LRS, Borja PC. Política e regulamentação do saneamento na Bahia: Situação atual e necessidade de arcabouço jurídico-institucional. In: Anais do 21 Congresso Brasileiro de Engenharia Sanitária e Ambiental; 2001 set 16-20; João Pessoa - Brasil. Associação Brasileira de Engenharia Sanitária e Ambiental; 2001. 19p.

75. Motta RD. Epistemología de la tecnologia: Una aproximación a la definición de tecnología y a las nociones de tecnologías adecuadas y/o apropiadas [monografia on line]. Universidad Del Salvador. Buenos aires: Instituto Internacional para El Pensamiento Complejo; 1996. 
Disponível <URL: http://www.compleijidad.org/iipc/voodtec.doc>. [05 mai 2002].

76. [MS] Ministério da Saúde. Fundação Serviços de Saúde Pública - 45 anos: Pioneirismo em saúde pública. Rio de Janeiro: Fundação SESP. 1987.

77. [MS] Ministério da Saúde - Fundação Nacional de Saúde. Manual de Saneamento. 3르 ed. Brasília: FUNASA; 1999.

78. [MS] Ministério da Saúde. Portaria no 1469 de 29/12/2000. Estabelece os procedimentos e responsabilidades relativas ao controle e vigilância da qualidade da água para consumo humano e seu padrão de potabilidade, e dá outras providências. Diário Oficial da União no 1-E de 02/01/2001. Seção I, p.19 e republicada no DOU no 7-E de 10/01/2001. Seção I, p. 26.

79. Najar AL. Políticas públicas no Brasil: Estado de bem-estar social ou de segurança nacional? Uma discussão sobre a política de saneamento para as áreas urbanas entre 1970/1984. Rio de Janeiro; 1991. [Dissertação de Mestrado - Centro de Ciências Jurídicas e Econômicas da Universidade Federal do Rio de Janeiro].

80. Northrop-Clewes CA, Ahmad N, Paracha P, Thurnham D. Impact of health service provision on mothers and infants in a rural village in North West Frontier Province, Pakistan. Public Health Nutrition.1998; 1, 1: 51 - 59.

81. Orrico SRM. The feasibility of uasb reactor to treat different feedstock. Manchester; 1992. [Dissertação de Mestrado - UMIST Victoria University of Manchester]. 
82. Ottani V, Rivero RH, Oliveira ML, Londoño A, Pereira DS, Velasco V de et al, Subsídios para elaboração de programas estaduais de saneamento rural. Série Saneamento Rural 3, IPEA/IPLAN. Brasília: $1989 ; 11-67$.

83. Ovalles $\mathrm{O}$, Viezzer ML. Manual Latino-Americano de educ-ação ambiental. São Paulo: Gaia, 1995.

84. Paganini W da S. Disposição de Esgotos no solo: (escoamento à superfície). $2^{\text {a }}$ ed. São Paulo: AESABESP; 1997.

85. [PLANARQ] Planejamento Ambiental e Arquitetura LTDA. Avaliação ambiental da barragem de Pindobaçu. Salvador: PLANARQ; 2001.

86. Prieto PA, Martín J, Marie GC. La calidad del agua de consumo y las enfermedades diarreicas en Cuba, 1996 - 1997. Rev Panam Salud Publica/ Pan Am Journal of Public Health, 2000; 7, 5: 313 - 318.

87. Quick RE, Venczel LV, Mintz ED, Soleto L, Aparicio J, Gironaz M et al. Diarrhoea prevention in Bolivia through point-of-use water treatment and safe storage: a promising new strategy. Epidemiology Infection. 1999. 122, 1: $83-90$.

88. Rebouças A da C, Braga B, Tundisi JG. Águas doces do Brasil Capital Ecológico, uso e conservação. São Paulo: Escritura; 1999. [Instituto de Estudos Avançados da USP e Academia Brasileira de Ciências]

89. Rezende SC, Heller L. O saneamento no Brasil. Belo Horizonte: UFMG; 2002. 
90. Roberts L. Conclusion from literature: an overview if epidemiological associations between water, sanitation, and disease. In: Heller L. Moraes LRS, Monteiro TC do N, Salles MJ, Almeida LM de, Câncio J, et al. Saúde e saneamento em países em desenvolvimento. Rio de Janeiro: CC\&P Editores Ltda; 1997. p. 220-237.

91. Rocha AL, Barreto D. Perfil do consumo de água de uma habitação unifamiliar. Anais do 20 Congresso Brasileiro de Engenharia Sanitária e Ambiental; 1999 mai 10 - 14; Rio de Janeiro - Brasil. Associação Brasileira de Engenharia Sanitária e Ambiental; 1999. 7p.

92. Rodrigues JMC. Avaliação de projetos de saneamento básico. Rev DAE. 1985; 45(141): $127-141$.

93. Salles MJ. Indicadores das Condições de Saneamento do Ambiente. Rio de Janeiro; 1994. [Dissertação de Mestrado - Escola Nacional de Saúde Pública da Fundação Oswaldo Cruz].

94. Santos J A de O. Soluções de baixo custo para problemas de saneamento ambiental. São Paulo; 1990 [Dissertação de Mestrado Faculdade de Saúde Pública da USP].

95. Schweizer LT., Nieradtka K. "Publicização", uma alternativa aos extremos da privatização e da estatização: um estudo do caso do Sisar, no setor de água e saneamento. Rev de Administração Pública. 2001. 24(2): 153-191.

96. Sperling MV. Lagoas de estabilização. Belo Horizonte: Departamento de Engenharia Sanitária e Ambiental - UFMG; 1996. v. 3 


\section{APÊNDICE}


Apêndice A Modelo do Questionário aplicado na população das localidades 
UNIVERSIDADE ESTADUAL DE FEIRA DE SANTANA DOUTORADO EM SAÚDE PÚBLICA USP/UEFS

\begin{tabular}{|c|c|c|}
\hline Município: & Localidade: & Questionário: \\
\hline Nome: & Endereço: & \\
\hline
\end{tabular}

\section{I-ANTES DA CHEGADA DO PROGRAMA DE SANEAMENTO BÁSICO}

Q1 - Quantas pessoas moravam na casa?

Antes
Depois... - -

Q2 - De onde vinha a água para o uso doméstico?

1)...Chafariz (2)

2)...Carro pipa (2)

3)...Ligação domiciliar (1)

4)...Rio (3)

5)...Barragem/Presa (3)

6)...Fonte (2)

7)...Cacimba (2)

8)...Outros...(especificar)

9)...NS/NR

8. Outros

8.3. Cisterna e Cisterna do vizinho (2)

8.4. Cisterna (2)

8.5. Chuva (2)

8.6. Vizinho (2)

Q3 - Qual era o consumo diário de água?
1)... 1 Lata
2)... 2 Latas
3)... 2 a 4 Latas
4)... 4 a 6 Latas
5)...Mais de 6 Latas
8)...Outros...(Especificar)
9)...NS/NR

Q4 - Quem transportava a água?

1)...Membros da família (vá para $Q 7$ )

2)...Comprava de terceiros (vá para Q5 e Q6)

8)...Outros (especificar) (vá para Q7)

Q5 - Se comprava quanto pagava por litro(ou outra medida) para ter água em sua casa?

Q6 - Com que frequência comprava a água?
1) Diariamente
2) 2 vezes por semana
3) 3 vezes por semana
4) Semanalmente
8) Outros...(Especificar)
9) $\mathrm{NS} / \mathrm{NR}$

Q7 - Quanto tempo gastava para pegar água durante o dia? (h/dia)
1) 30 minutos
2) 1 Hora
3) 2 Horas
4) 3 Horas
5) 4 Horas
6) Mais de 4 Horas
9) NS/NR 
Q8 - Onde armazenava a água?
1) Caixa d'água (1)
2) Tonel (2)
3) Baldes (3)
4) Latas (3)
5) Não armazenava (1)
8) Outros...(especificar)
9) NS/NR

8. Outros

8.3. Potes (1)

8.4. Cisterna (1)

8.5. Chuva (1)

8.6. Potes e Cisterna (1)

8.7. Potes c Camburão (1)

Q9 - Qual água usava para beber?
1) Chafariz (2)
2) Carro pipa (2)
3) Ligação domiciliar (1)
4) Rio (3)
5) Barragem/presa (3)
6) Fonte (2)
7) Cacimba (2)
8) Outros...(especificar)
9) NS/NR

8.3. Cisterna (2)

\section{Outros}

8.4. Vizinho (2)

8.5. Chuva (2)

8.6.

8.7. Cisterna e Vizinho (2)

Q10- A água que bebia era saudável?
1) $\mathrm{Sim}$
2) Não
3) Sim, mas precisava tratar.
9) NS/NR

Q11- Qual tipo de tratamento utilizava para a água de beber?
1) Filtrava (2)
2) Coava (2)
3) Fervia (1)
4) Filtrava/Fervia (2)
5) Coava/Filtrava (2)
6) Coava/Fervia (1)
7) Cloro (1)
9) NS/NR
10) Decantava (2)
12) Nenhum

11) Peixes (2) * * hábito de criar peixe para evitar proliferação de insetos

Q12- Possuía:
1) Pia de cozinha
2) Tanque de lavar roupa
3) Chuveiro
4) Privada com vaso sanitário
5) Descarga
6) Lavatório
7) Fossa seca
8) Fossa séptica
9) NS/NR

Q13- Na localidade existia rede de esgoto?

1) $\mathrm{Sim}$

2) Não 
Q14- Onde lavava os alimentos?

1) Pia de cozinha (1)

2) Bacia (2)

3) Rio (3)

4) Tanque de lavar roupa (2)

8) Outros...(especificar)

Q15- Onde lavava os utensílios domésticos?

1) Pia de cozinha (1)

2) Bacia (2)

3) Rio (3)

4) Tanque de lavar roupa (2)

8) Outros...(especificar)

\section{Outros}

8.3. Presa (3) * pequena represa. 8.4. Rio (3)

\section{Q16- Onde lavava as mãos?}

1) Lavatório (1)

2) Bacia (2)

8) Outros...(especificar)

\section{Outros}

8.3. Pia de cozinha (1)

8.4. Tanque de lavar roupa (1)

8.5. Pia de cozinha e tanque de lavar roupa (1)

\title{
Q17- Onde escovava os dentes?
}
1) Lavatório
2) Céu Aberto
8) Outros...(especificar)

8. Outros

8.3. Tanque de Lavar Roupa

\section{Q18- Onde lavava as roupas? \\ 1) Lavanderia Pública (1) \\ 2) Bacia (1) \\ 3) Tanque de lavar roupa (1) \\ 8) Outros...(especificar)}

\section{Outros}

8.3. Presa (3)

8.4. Rio (2)

8.5. Fonte (2)

Q19- Onde tomava banho?
1) Banheiro (1)
2) Casa do vizinho (1)
3) Rio (2)
4) Bacia (2)
5) Céu aberto
8) Outros...(especificar)

\section{Outros}

8.3. Presa (3)

8.4. Fonte (2)

\section{Q20- Qual a frequência diária do banho?}
1) Uma vez (1)
2) Duas ou mais vezes (1)
3) Nem todos os dias (2)
8) Outros...(especificar)

\author{
Q21- Onde fazia cocô? \\ 1) Sanitário (1) \\ 2) Casa do vizinho (1) \\ 3) Mato (3) \\ 4) Fossa seca (2) \\ 5) Em recipiente e jogava fora (balão) (3) \\ 8) Outros...(especificar)
}

\section{Outros \\ 8.3. Buraco no chão (3)}


Q22 - Possui ligação domiciliar (água da CENTRAL)?
1)...Sim
2)...Não, mas já tive.
3)...Não, mas vou ligar.
4).... Não e não quero

Q23 - Qual o consumo mensal de água?
1)...Até $10 \mathrm{~m}^{3}$
2)...Entre 10 e $12 \mathrm{~m}^{3}$
3)...Entre $12 \mathrm{e} 15 \mathrm{~m}^{3}$

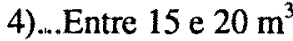
5)...Mais de $20 \mathrm{~m}^{3}$
8)...Outros...(especificar)
9)...NS/NR

Q24 - Qual o valor da última conta de água?
1)...até 6 reais
2)...Entre 6 e 8 reais
3)...Entre 8 e 10 reais
4)...Entre 10 e 15 reais
5)...Mais de 20 reais
8)...Outros...(especificar)
9)...NS/NR

Q25 - Qual a água utilizada para beber?
1)...Rede da CENTRAL (1)
2)...Água Mineral (1)
3)...Fonte (3)
4)...Poço (3)
5)...Barragem/Presa (3)
6)...Rio (3)
8)...Outros (especificar)

8.3. Cisterna (1)

8.4. Vizinho (2)

8.5. Chuva e casa do vizinho (2)

8.6. Chuva (1)

8.7. Cacimba (2)

8.8. Cisterna e vizinho (2)

Q26 - Onde armazena a água de beber?
1)...Caixa d'água (1)
2)...Tonel (2)
3)...Baldes (3)
4)...Latas (3)
5)...Não armazena
8)...Outros (especificar)

8. Outros

Q27 - Qual o tratamento utilizado para a água de beber?

1)...Filtra (2)

2)...Côa (2)

3)...Ferve (1)

4)...Filtra/Ferve (2)

5)...Côa/Filtra (1)

6)...Côa/Ferve (1)

7)...Ozonizador (1)

8)...Outros (especificar)

9)...NS/NR
8.3. Potes (1)

8.4. Cisterna (1)

8.5. Potes e Cisterna (1)

8.6. Filtro (1)

\section{Outros}


Q28 - Fez alguma melhoria na casa depois da chegada da água (Programa)?
1)...Pia de cozinha
2)...Chuveiro
3)...Tanque de lavar roupa
4)...Descarga
5)...Lavatório
6)...Ampliação do sanitário
8)...Outros (especificar)
9)...NS/NR

Q29 - Pretende fazer alguma melhoria?

1)...Pia de cozinha

2)...Chuveiro

3)...Tanque de lavar roupa

4)...Descarga

5)...Lavatório

6)...Ampliação do sanitário

8)...Outros...(especificar)

9)...NS/NR

Q30 - Onde lava os alimentos?

1)...Pia de cozinha (1)

2)...Bacia (2)

3)...Tanque de lavar roupa (1)

8)...Outros...(especificar)

9)...NS/NR

Q31 - Onde lava os utensílios?

1)...Pia de cozinha (1)

2)...Bacia (2)

3)...Tanque de lavar roupa (1)

4)...Presa (3)

5)...Rio (3)

6)...Chafariz (2)

8)...Outros (especificar)

9)...NS/NR

Q32 - Onde lava as mãos?

1)...Lavatório (1)

2)...Bacia (2)

3)...Tanque de lavar roupa (1)

8)...Outros (especificar)

9)...NS/NR

Q33 - Onde escova os dentes?

1)...Lavatório (1)

2)...Céu aberto (2)

3)...Tanque de lavar roupa (1)

8)...Outros (especificar)

9)...NS/NR

Cisterna

8.5. Ampliou o Hotel 
Q34 - Onde lava as roupas?

1)...Pia de cozinha (2)

2)...Bacia (1)

3)...Tanque de lavar roupa (1)

8. Outros

4)...Presa (3)

8.3. Presa (3)

5)...Rio (3)

6)...Chafariz (2)

8.4. Fonte (2)

8)...Outros (especificar)

9)...NS/NR

Q35 - Onde toma banho?

1)...Banheiro (1)

2)...Casa do vizinho (1)

3)...Rio (3)

4)...Céu aberto (2)

8. Outros

8)...Outros...(especificar)

8.4. Quartinho (2) *Sanitário improvisado em pequeno espaço fechado.

Q36 - Qual a frequência do banho?
1)...Uma vez ao dia (1)
2)...Duas ou mais vezes ao dia (1)
3)...Nem todos os dias (2)
8)...Outros...(especificar)

\section{Q37 - Onde faz cocô?}

1)...Sanitário (1)

2)...Casa do vizinho (1)

3)...Mato (3)

4)...Fossa seca (2)

5)...Em Recipiente e joga fora (3)

8)...Outros...(especificar)

Q38 - Qual o destino dos esgotos?
1)...Fossa
2)...Rede geral
3)...Escoa na rua (a céu aberto)
8)...Outros...(especificar)

Q39 - Percebe alguma mudança na saúde depois da chegada da água e do esgotamento sanitário, com relação a:
1)...Diarréia
2)...Dores de barriga
3)...Dores nas costas, cansaço.
4)...Doença de pele
5)...Não mudou nada
8)...Outros...(especificar)

9)...NS/NR

Q40 - Com a chegada da água, você acha que ganhou mais tempo para:
1)...Cuidar da casa
2)...Cuidar dos filhos
3)...Trabalhar em casa
4)...Descansar
5)...Trabalhar fora
6)...Lazer
8)...Outros...(especificar)
9)...NS/NR 
Q41- Você acha que sua propriedade valorizou mais com a chegada da água (programa)?

1)...Sim

2)...Não

9)...NS/NR

Q42 - Você sabe como é gasto o dinheiro da conta de água?

Q43 Você acha que melhorou a qualidade de vida em sua casa?

1)...Sim

2)...Não

9)...NS/NR 
Apêndice B Modelo do Questionário aplicado aos presidentes das associações de moradores das localidades 


\section{III - PERGUNTAS PARA O PRESIDENTE DA ASSOCIAÇÃo}

1 - DEPOIS DA CHEGADA DO PROGRAMA DE SANEAMENTO BÁSICO:

1.1 - Como ficou o valor do aluguel e/ou venda de casas (antes e depois)?

1.2 - Aumentou o fluxo de pessoas? de casas habitadas? de novas construções?

1.3 - Houve alguma melhoria na localidade?

1.4 - Quais as atividades da Associação?

( ) Sistema da água ( ) Casa de farinha ( ) Coleta de lixo ( ) Festas

( ) Auxílio para tratamento de saúde ( ) Outras

1.5 - Alguma nova reivindicação da comunidade para a Associação: 
Tabelas 34 a 51

Tabela 34 Local de armazenagem de água antes do saneamento, segundo localidades do semi-áridọ baiano, 2002.

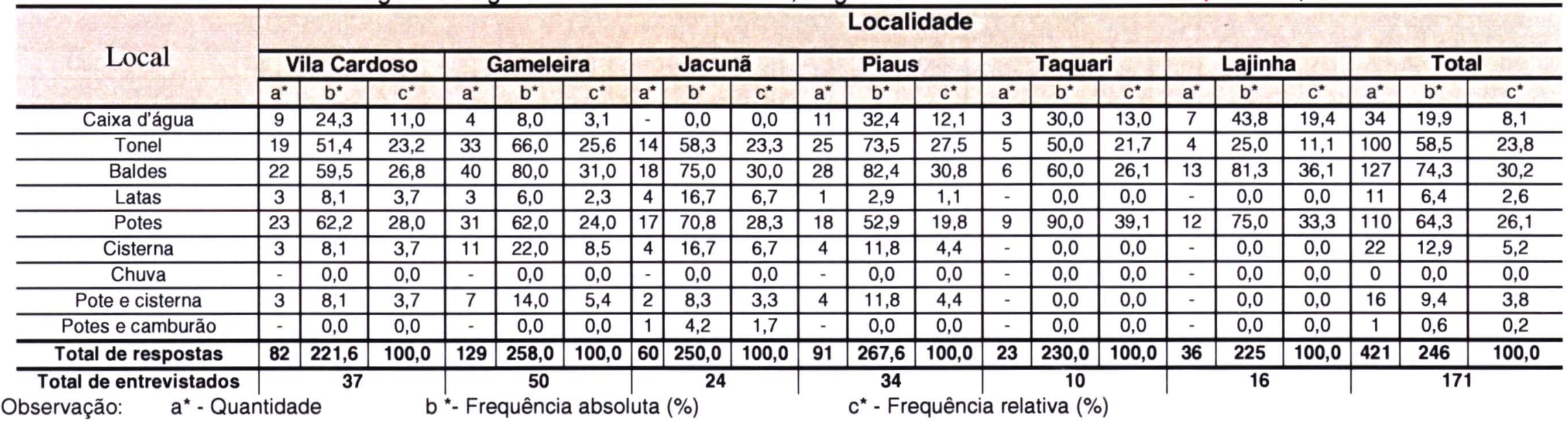

Tabela 35 Local de armazenagem de água depois do saneamento, segundo localidades do semi-árido baiano, 2002.

\begin{tabular}{|c|c|c|c|c|c|c|c|c|c|c|c|c|c|c|c|c|c|c|c|c|c|}
\hline \multirow{3}{*}{ Local } & \multicolumn{21}{|c|}{ Localidade } \\
\hline & \multicolumn{3}{|c|}{ Vila Cardoso } & \multicolumn{3}{|c|}{ Gameleira } & \multicolumn{3}{|c|}{ Jacunã } & \multicolumn{3}{|c|}{ Piaus } & \multicolumn{3}{|c|}{ Taquari } & \multicolumn{3}{|c|}{ Lajinha } & \multicolumn{3}{|c|}{ Total } \\
\hline & $a^{*}$ & $\overline{b^{*}}$ & $\mathrm{C}^{\star}$ & $a^{*}$ & $\mathrm{~b}^{*}$ & $\mathrm{C}^{*}$ & $a^{*}$ & $\mathrm{~b}^{*}$ & $\mathrm{C}^{*}$ & $a^{*}$ & $\mathrm{~b}^{*}$ & $\mathrm{C}^{*}$ & $a^{*}$ & $\mathrm{~b}^{*}$ & $\mathrm{c}^{*}$ & $a^{*}$ & $\mathrm{~b}^{*}$ & $\mathrm{C}^{*}$ & $a^{*}$ & $\mathrm{~b}^{*}$ & $\mathrm{C}^{*}$ \\
\hline Caixa d'água & 10 & 27,0 & 16,4 & 26 & 53,1 & 34,2 & 2 & 8,3 & 4,9 & 8 & 23,5 & 14,3 & 3 & 30,0 & 21,4 & 11 & 68,8 & 68,8 & 60,0 & 35,3 & 22,7 \\
\hline Tonel & 9 & 24,3 & 14,8 & \begin{tabular}{|l|}
10 \\
\end{tabular} & 20,4 & 13,2 & 6 & 25,0 & 14,6 & 10 & \begin{tabular}{|l|}
29,4 \\
\end{tabular} & 17,9 & 2 & 20,0 & 14,3 & - & 0,0 & 0,0 & 37 & 21,8 & 14,0 \\
\hline Baldes & 11 & 29,7 & 18,0 & 2 & 4,1 & 2,6 & 12 & 50,0 & 29,3 & 8 & 23,5 & 14,3 & 3 & 30,0 & 21,4 & - & 0,0 & 0,0 & 36 & 21,2 & 13,6 \\
\hline Latas & 1 & 2,7 & 1,6 & - & 0,0 & 0,0 & - & 0,0 & 0,0 & - & 0,0 & 0,0 & - & 0,0 & 0,0 & - & 0,0 & 0,0 & 1 & 0,6 & 0,4 \\
\hline Não armazena & 5 & 13,5 & 8,2 & 1 & 2,0 & 1,3 & - & 0,0 & 0,0 & - & 0,0 & 0,0 & - & 0,0 & 0,0 & - & 0,0 & 0,0 & 6 & 3,5 & 2,3 \\
\hline Potes & 19 & 51,4 & 31,1 & \begin{tabular}{|l|}
15 \\
\end{tabular} & 30,6 & 19,7 & 14 & 58,3 & 34,1 & 18 & \begin{tabular}{|l|}
52,9 \\
\end{tabular} & 32,1 & 1 & 10,0 & 7,1 & 4,0 & 25,0 & 25,0 & 71 & 41,8 & 26,9 \\
\hline Cisterna & 4 & 10,8 & 6,6 & \begin{tabular}{|l|}
17 \\
\end{tabular} & 34,7 & 22,4 & 7 & 29,2 & 17,1 & 8 & \begin{tabular}{|l|}
23,5 \\
\end{tabular} & 14,3 & 5 & 50,0 & 35,7 & - & 0,0 & 0,0 & 41 & 24,1 & 15,5 \\
\hline Pote e cisterna & 2 & 5,4 & 3,3 & 4 & 8,2 & 5,3 & - & 0,0 & 0,0 & 4 & 11,8 & 7,1 & - & 0,0 & 0,0 & - & 0,0 & 0,0 & 10 & 5,9 & 3,8 \\
\hline Filtro & - & 0,0 & 0,0 & 1 & 2,0 & 1,3 & - & 0,0 & 0,0 & - & 0,0 & 0,0 & - & 0,0 & 0,0 & 1,0 & 6,3 & 6,3 & 2 & 1,2 & 0,8 \\
\hline Total de respostas & 61 & 164,9 & 100,0 & 76 & 155,1 & 100,0 & 41 & 170,8 & 100,0 & 56 & 164,7 & 100,0 & 14 & 140,0 & 100,0 & 16 & 100 & 100,0 & 264 & 155 & 100,0 \\
\hline Total de entrevistados & \multicolumn{3}{|c|}{37} & \multicolumn{3}{|c|}{49} & \multicolumn{3}{|c|}{24} & \multirow{2}{*}{\multicolumn{3}{|c|}{34}} & \multirow{2}{*}{\multicolumn{3}{|c|}{$\begin{array}{c}10 \\
a(\%)\end{array}$}} & \multirow{2}{*}{\multicolumn{3}{|c|}{16}} & \multirow{2}{*}{\multicolumn{3}{|c|}{170}} \\
\hline Observação: & ntida & & & 更 & quênci & a absc & $d a$ & & & & & & & & & & & & & & \\
\hline
\end{tabular}


Tabela 36 Origem da água de beber antes do saneamento, segundo localidades do semi-árido baiano, 2002.

\begin{tabular}{|c|c|c|c|c|c|c|c|c|c|c|c|c|c|c|c|c|c|c|c|c|c|}
\hline \multirow{3}{*}{ Origem } & \multicolumn{21}{|c|}{ Localidade } \\
\hline & \multicolumn{3}{|c|}{ Vila Cardoso } & \multicolumn{3}{|c|}{ Gameleira } & \multicolumn{3}{|c|}{ Jacunã } & \multicolumn{3}{|c|}{ Piaus } & \multicolumn{3}{|c|}{ Taquari } & \multicolumn{3}{|c|}{ Lajinha } & \multicolumn{3}{|c|}{ Total } \\
\hline & $a^{\star}$ & $b^{*}$ & $c^{*}$ & $a^{\star}$ & $b^{*}$ & $\mathrm{c}^{\star}$ & $a^{\star}$ & $\mathbf{b}^{\star}$ & $\mathrm{c}^{\star}$ & $a^{\star}$ & $b^{\star}$ & $\mathrm{c}^{\star}$ & $a^{\star}$ & $\mathbf{b}^{\star}$ & $c^{*}$ & $\mathbf{a}^{*}$ & $\mathbf{b}^{*}$ & $\mathrm{c}^{*}$ & $a^{*}$ & $\mathbf{b}^{\star}$ & $c^{*}$ \\
\hline Carro pipa & 25 & 67,6 & 32,1 & 48 & 96 & 33,8 & 24 & 100,0 & 33,8 &  & 0,0 & 0,0 & & 0,0 & 0,0 & & 0,0 & 0,0 & 97 & 56,7 & 26,0 \\
\hline Ligação d & 4 & 10,8 & 5,1 & - & 0,0 & 0,0 & 23 & 95 & 32,4 & - & 0,0 & 0,0 & - & 0,0 & 0,0 & 13 & 81,3 & 38,2 & 13 & 7,6 & 3,5 \\
\hline B & 28 & 75,7 & 35,9 & - & 0,0 & 0,0 & - & 0,0 & 0,0 & 6 & 17 & 9,2 & 4 & 40,0 & 40,0 &  & 0,0 & 0,0 & 38 & 22,2 & 10,2 \\
\hline onte & - & 0,0 & 0,0 & 45 & 90,0 & 31,7 & - & 0,0 & 0,0 & 19 & 55,9 & 29,2 & 3 & 30,0 & 30,0 & - & 0,0 & 0,0 & 67 & 39,2 & 18,0 \\
\hline Cacin & - & 0,0 & 0,0 & - & 0,0 & 0,0 & - & 0,0 & 0,0 & 27 & 79,4 & 41,5 & - & 0,0 & 0,0 & - & 0,0 & 0,0 & 27 & 15,8 & 7,2 \\
\hline Chafariz & - & 0,0 & 0,0 & - & 0,0 & 0,0 & - & 0,0 & 0,0 & - & 0,0 & 0,0 & - & 0,0 & 0,0 & 8,0 & 50,0 & 23,5 & 8 & 4,7 & 2,1 \\
\hline & - & 0,0 & 0,0 & - & 0,0 & 0,0 & - & 0,0 & 0,0 & - & 0 & 0,0 & - & 0,0 & 0,0 & 13 & 81,3 & 38,2 & 13 & 7,6 & 3,5 \\
\hline Cist & 11 & 29,7 & 4,1 & 35 & 70,0 & 24,6 & 8 & 33,3 & 11,3 & 8 & 23,5 & 12,3 & 3 & 30,0 & 30,0 & - & 0,0 & 0,0 & 65 & 38,0 & 17,4 \\
\hline Chuva & 10 & 27,0 & 12,8 & 14 & 28,0 & 9,9 & 16 & 66,7 & 22,5 & 4 & 11,8 & 6,2 & - & 0,0 & 0,0 & - & 0,0 & 0,0 & \begin{tabular}{|l|}
44 \\
\end{tabular} & 25,7 & 11,8 \\
\hline Cist. e Vizinho. & - & 0,0 & 0,0 & - & 0,0 & 0,0 & - & 0,0 & 0,0 & 1 & 2,9 & 1,5 & - & 0,0 & 0,0 & - & 0,0 & 0,0 & 1 & 0,6 & 0,3 \\
\hline Total de resposta & 78 & 210,8 & 100,0 & 142 & 284,0 & 100,0 & 71 & 295,8 & 100,0 & 65 & 191,2 & 100,0 & 10 & 100,0 & 100,0 & 34 & 213 & 100,0 & 373 & 218 & 100, \\
\hline Total de entrevistados & & 37 & & & 50 & & & 24 & & & 34 & & & 10 & & & 16 & & & 171 & \\
\hline$\tilde{n}$ & antic & ade & & & requenc & cla a a & . Soluc & $a(\%)$ & & & $c-r_{1}$ & requenc & & va & & & & & & & \\
\hline
\end{tabular}

Tabela 37 Origem da água de beber depois do saneamento, segundo localidades do semi-árido baiano, 2002.

\begin{tabular}{|c|c|c|c|c|c|c|c|c|c|c|c|c|c|c|c|c|c|c|c|c|c|}
\hline \multirow{3}{*}{ Origem } & \multicolumn{21}{|c|}{ Localidades } \\
\hline & \multicolumn{3}{|c|}{ Vila Cardoso } & \multicolumn{3}{|c|}{ Gameleira } & \multicolumn{3}{|c|}{ Jacunã } & \multicolumn{3}{|c|}{ Piaus } & \multicolumn{3}{|c|}{ Taquari } & \multicolumn{3}{|c|}{ Lajinha } & \multicolumn{3}{|c|}{ Total } \\
\hline & $a^{*}$ & $\mathbf{b}^{\star}$ & $c^{*}$ & $a^{*}$ & $\mathbf{b}^{*}$ & $c^{*}$ & $a^{*}$ & $\mathbf{b}^{*}$ & $\overline{c^{*}}$ & $a^{*}$ & $\mathbf{b}^{*}$ & $c^{*}$ & $\mathbf{a}^{*}$ & $\mathbf{b}^{*}$ & $\mathrm{c}^{\star}$ & $a^{\star}$ & $\mathbf{b}^{*}$ & $c^{*}$ & $\mathbf{a}^{*}$ & $\mathbf{b}^{\star}$ & $\mathrm{c}^{*}$ \\
\hline Central & 19 & 51,4 & 38,0 & 42 & 84,0 & 66,7 & 22 & 91,7 & 75,9 & 25 & 73,5 & 48,1 & 3 & 27,3 & 33,3 & 15 & 93,8 & 93,8 & 126 & 73,3 & 57,5 \\
\hline Barra/Presa & 13 & 35,1 & 26,0 & 2 & 4,0 & 3,2 & - & 0,0 & 0,0 & - & 0,0 & 0,0 & - & 0,0 & 0,0 & - & 0,0 & 0,0 & 15 & 8,7 & 6,8 \\
\hline Fonte & - & 0,0 & 0,0 & - & 0,0 & 0,0 & 2 & 8,3 & 6,9 & \begin{tabular}{|l|}
14 \\
\end{tabular} & 41,2 & 26,9 & - & 0,0 & 0,0 & - & 0,0 & 0,0 & 16 & 9,3 & 7,3 \\
\hline Rio & - & 0,0 & 0,0 & - & 0,0 & 0,0 & - & 0,0 & 0,0 & - & 0,0 & 0,0 & - & 0,0 & 0,0 & 1,0 & 6,3 & 6,3 & 1 & 0,6 & 0,5 \\
\hline Cisterna & 10 & 27,0 & 20,0 & 17 & 34,0 & 27,0 & 1 & 4,2 & 3,4 & 12 & 35,3 & 23,1 & 5 & 45,5 & 55,6 & - & 0,0 & 0,0 & 45 & 26,2 & 20,5 \\
\hline Chuva & \begin{tabular}{|l|}
8 \\
\end{tabular} & 21,6 & 16,0 & 2 & 4,0 & 3,2 & 4 & 16,7 & 13,8 & - & 0,0 & 0,0 & 1 & 9,1 & 11,1 & - & 0,0 & 0,0 & 15 & 8,7 & 6,8 \\
\hline Cacimba & - & 0,0 & 0,0 & - & 0,0 & 0,0 & - & 0,0 & 0,0 & 1 & 2,9 & 1,9 & - & 0,0 & 0,0 & - & 0,0 & 0,0 & 1 & 0,6 & 0,5 \\
\hline Total de respostas & 50 & 135,1 & 100,0 & 63 & 126,0 & 100,0 & 29 & 120,8 & 100,0 & 52 & 152,9 & 100,0 & 9 & 81,8 & 100,0 & 16 & 100 & 100,0 & 219 & 127 & 100,0 \\
\hline Total de entrevistados & \multicolumn{3}{|c|}{37} & \multirow{2}{*}{\multicolumn{3}{|c|}{$\begin{array}{c}50 \\
\text { Frequência a }\end{array}$}} & \multirow{2}{*}{\multicolumn{3}{|c|}{24}} & \multirow{2}{*}{\multicolumn{3}{|c|}{34}} & \multirow{2}{*}{\multicolumn{3}{|c|}{$\begin{array}{l}10 \\
\text { tiva (\%) }\end{array}$}} & \multirow{2}{*}{\multicolumn{3}{|c|}{16}} & \multirow{2}{*}{\multicolumn{3}{|c|}{171}} \\
\hline Observação: & antid & lade & & $b^{*}-F$ & & & & & & & & que & & & & & & & & & \\
\hline
\end{tabular}


Tabela 38 Tipo de tratamento de água antes do saneamento, segundo localidades do semi-árido baiano, 2002.

\begin{tabular}{|c|c|c|c|c|c|c|c|c|c|c|c|c|c|c|c|c|c|c|c|c|c|}
\hline \multirow{3}{*}{ Tratamento } & \multicolumn{21}{|c|}{ Localidade } \\
\hline & \multicolumn{3}{|c|}{ Vila Cardoso } & \multicolumn{3}{|c|}{ Gameleira } & \multicolumn{3}{|c|}{ Jacunã } & \multicolumn{3}{|c|}{ Piaus } & \multicolumn{3}{|c|}{ Taquari } & \multicolumn{3}{|c|}{ Lajinha } & \multicolumn{3}{|c|}{ Total } \\
\hline & $a^{*}$ & $\mathbf{b}^{\star}$ & $c^{\star}$ & $a^{\star}$ & $\mathbf{b}^{\star}$ & $c^{\star}$ & $a^{*}$ & $\mathbf{b}^{\star}$ & $c^{*}$ & $a^{*}$ & $\mathbf{b}^{\star}$ & $c^{\star}$ & $a^{\star}$ & $\mathbf{b}^{\star}$ & $c^{*}$ & $a^{*}$ & $\mathbf{b}^{\star}$ & $c^{*}$ & $a^{*}$ & $\mathbf{b}^{\star}$ & $c^{*}$ \\
\hline Côa & 8 & 21,6 & 13,1 & 22 & 44,0 & 16,7 & 9 & 37,5 & \begin{tabular}{|l|}
18,4 \\
\end{tabular} & 14 & 41,2 & 29,8 & 5 & 50,0 & 41,7 & 1 & 6,7 & 5,0 & 59 & 34,7 & 18,4 \\
\hline Côa e filtra & 29 & 78,4 & 47,5 & 29 & 58,0 & 22,0 & 15 & \begin{tabular}{ll|}
62,5 \\
\end{tabular} & 30,6 & 19 & \begin{tabular}{|l|}
55,9 \\
\end{tabular} & 40,4 & 5 & 50,0 & 41,7 & 11 & 73,3 & 55,0 & 108 & 63,5 & 33,6 \\
\hline Cloro & 9 & 24,3 & 14,8 & 32 & 64,0 & 24,2 & 13 & 54,2 & 26,5 & 8 & 23,5 & 17,0 & 1 & 10,0 & 8,3 & 4,0 & 26,7 & 20,0 & 67 & 39,4 & 20,9 \\
\hline Decanta & 14 & 37,8 & 23,0 & 24 & 48,0 & 18,2 & 11 & 45,8 & 22,4 & 4 & \begin{tabular}{|l|}
11,8 \\
\end{tabular} & 8,5 & - & 0,0 & 0,0 & 2,0 & 13,3 & 10,0 & 55 & 32,4 & 17,1 \\
\hline Peixe & 1 & 2,7 & 1,6 & 25 & 50,0 & 18,9 & 1 & 4,2 & 2,0 & - & 0,0 & 0,0 & - & 0,0 & 0,0 & - & 0,0 & 0,0 & 27 & 15,9 & 8,4 \\
\hline Filtra & - & 0,0 & 0,0 & - & 0,0 & 0,0 & - & 0,0 & 0,0 & 1 & 2,9 & 2,1 & - & 0,0 & 0,0 & 2,0 & 13,3 & 10,0 & 3 & 1,8 & 0,9 \\
\hline Ferve & 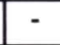 & 0,0 & 0,0 & - & 0,0 & 0,0 & - & 0,0 & 0,0 & 1 & 2,9 & 2,1 & 1 & 10,0 & 8,3 & - & 0,0 & 0,0 & 2 & 1,2 & 0,6 \\
\hline Total de respostas & 61 & 164,9 & 100,0 & 132 & 264,0 & 100,0 & 49 & 204,2 & 100,0 & 47 & 138,2 & 100,0 & 12 & 120,0 & 100,0 & 20 & 133 & 100,0 & 321 & 189 & 100,0 \\
\hline Total de entrevistados & & 37 & & & 50 & & & 24 & & & 34 & & & 10 & & & 15 & & & 170 & \\
\hline & & & & &  & & & & & & & & & iva ( & & & & & & & \\
\hline
\end{tabular}

Tabela 39 Tipo de tratamento de água depois do saneamento, segundo localidades do semi-árido baiano, 2002.

\begin{tabular}{|c|c|c|c|c|c|c|c|c|c|c|c|c|c|c|c|c|c|c|c|c|c|}
\hline \multirow{3}{*}{ Tratamento } & \multicolumn{21}{|c|}{ Localidade } \\
\hline & \multicolumn{3}{|c|}{ Vila Cardoso } & \multicolumn{3}{|c|}{ Gameleira } & \multicolumn{3}{|c|}{ Jacunã } & \multicolumn{3}{|c|}{ Piaus } & \multicolumn{3}{|c|}{ Taquari } & \multicolumn{3}{|c|}{ Lajinha } & \multicolumn{3}{|c|}{ Total } \\
\hline & $a^{\star}$ & $\mathbf{b}^{\star}$ & $c^{*}$ & $\mathbf{a}^{*}$ & $\mathbf{b}^{*}$ & $c^{\star}$ & $\mathbf{a}^{\mathbf{*}}$ & $\mathbf{b}^{\star}$ & $c^{\star}$ & $a^{*}$ & $\mathbf{b}^{\star}$ & $c^{\star}$ & $\mathbf{a}^{\mathbf{*}}$ & $\mathbf{b}^{\star}$ & $c^{*}$ & $a^{*}$ & $\mathbf{b}^{\star}$ & $c^{*}$ & $a^{*}$ & $\mathbf{b}^{*}$ & $c^{*}$ \\
\hline Filtra & - & 0,0 & 0,0 & & 0,0 & 0,0 & 2 & 8,3 & 6,9 & 27 & 81,8 & 34,6 & & 0,0 & 0,0 & $\overline{9}$ & 60,0 & 60,0 & 38 & 22,5 & 15,6 \\
\hline Côa & 8 & 21,6 & 21,1 & 27 & 54,0 & 36,5 & 2 & 8,3 & 6,9 & 27 & 81,8 & 34,6 & 3 & 30,0 & 30,0 & 1,0 & 6,7 & 6,7 & 68 & 40,2 & 27,9 \\
\hline Ferve & - & 0,0 & 0,0 & - & 0,0 & 0,0 & - & 0,0 & 0,0 & - & 0,0 & 0,0 & - & 0,0 & 0,0 & - & 0,0 & 0,0 & 0 & 0,0 & 0,0 \\
\hline Côa e Filtra & 29 & 78,4 & 76,3 & 31 & 62,0 & 41,9 & 20 & 83,3 & 69,0 & 21 & 63,6 & 26,9 & 7 & 70,0 & 70,0 & 5,0 & 33,3 & 33,3 & 113 & 66,9 & 46,3 \\
\hline Ozônio & - & 0,0 & 0,0 & 1 & 2,0 & 1,4 & - & 0,0 & 0,0 & - & 0,0 & 0,0 & - & 0,0 & 0,0 & - & 0,0 & 0,0 & 1 & 0,6 & 0,4 \\
\hline Peixe & 1 & 2,7 & 2,6 & 14 & 28,0 & 18,9 & - & 0,0 & 0,0 & - & 0,0 & 0,0 & - & 0,0 & 0,0 & - & 0,0 & 0,0 & 15 & 8,9 & 6,1 \\
\hline Cloro & - & 0,0 & 0,0 & - & 0,0 & 0,0 & 5 & 20,8 & 17,2 & 3 & 9,1 & 3,8 & - & 0,0 & 0,0 & - & 0,0 & 0,0 & 8 & 4,7 & 3,3 \\
\hline Água. sanitária & - & 0,0 & 0,0 & 1 & 2,0 & 1,4 & - & 0,0 & 0,0 & - & 0,0 & 0,0 & - & 0,0 & 0,0 & & 0,0 & 0,0 & 1 & 0,6 & 0,4 \\
\hline Total de respostas & 38 & 102,7 & 100,0 & 74 & 148,0 & 100,0 & 29 & 120,8 & 100,0 & 78 & 236,4 & 100,0 & 10 & 100,0 & 100,0 & 15 & 100 & 100,0 & 244 & 144 & 100,0 \\
\hline Total de entrevistados & & 37 & & & 50 & & & 24 & & & 33 & & & 10 & & & 15 & & & 169 & \\
\hline Dbservação: & atid & lade & & $b^{*}-F$ & quê & $n$ & soluta & a (\%) & & & $\mathrm{c}^{*}-\mathrm{Fr}$ & requên & cha te & tiva $\left(^{\circ}\right.$ & & & & & & & \\
\hline
\end{tabular}


Tabela 40 Local de lavagem de alimentos antes do saneamento, segundo localidades do semi-árido baiano, 2002.

\begin{tabular}{|c|c|c|c|c|c|c|c|c|c|c|c|c|c|c|c|c|c|c|c|c|c|}
\hline \multirow{3}{*}{ Origem } & \multicolumn{21}{|c|}{ Localidades } \\
\hline & \multicolumn{3}{|c|}{ Vila Cardoso } & \multicolumn{3}{|c|}{ Gameleira } & \multicolumn{3}{|c|}{ Jacunã } & \multicolumn{3}{|c|}{ Piaus } & \multicolumn{3}{|c|}{ Taquari } & \multicolumn{3}{|c|}{ Lajinha } & \multicolumn{3}{|c|}{ Total } \\
\hline & $a^{\star}$ & $\mathbf{b}^{\star}$ & $c^{\star}$ & $a^{\star}$ & $\mathbf{b}^{\star}$ & $\mathbf{c}^{\star}$ & $\mathbf{a}^{\star}$ & $\mathbf{b}^{\star}$ & $c^{\star}$ & $a^{\star}$ & $\mathbf{b}^{*}$ & $c^{\star}$ & $a^{\star}$ & $\mathbf{b}^{\star}$ & $c^{\star}$ & $a^{*}$ & $\mathbf{b}^{*}$ & $c^{\star}$ & $\mathbf{a}^{\star}$ & $\mathbf{b}^{*}$ & $\mathrm{c}^{\star}$ \\
\hline Pia de cozinha & 22 & 59,5 & $\overline{59,5}$ & 29 & 58,0 & 58,0 & $\overline{9}$ & 37,5 & 37,5 & 22 & 64,7 & 66,7 & 7 & 70,0 & 70,0 & $\overline{4}$ & 25,0 & 66,7 & 93 & 54,4 & $\overline{58,1}$ \\
\hline Bacia & 15 & 40,5 & 40,5 & 21 & 42,0 & 42,0 & 15 & 62,5 & 62,5 & \begin{tabular}{|l|}
11 \\
\end{tabular} & 32,4 & 33,3 & 3 & 30,0 & 30,0 & 2,0 & 12,5 & 33,3 & 67 & 39,2 & 41,9 \\
\hline Total de respostas & 37 & 100,0 & 100,0 & 50 & 100,0 & 100,0 & 24 & 100,0 & 100,0 & 33 & 97,1 & 100,0 & 10 & $\overline{100,0}$ & 100,0 & 6 & 38 & 100,0 & 160 & 94 & $\overline{100,0}$ \\
\hline Total de entrevistados & \multicolumn{3}{|c|}{37} & \multicolumn{3}{|c|}{50} & \multicolumn{3}{|c|}{24} & \multicolumn{3}{|c|}{34} & \multirow{2}{*}{\multicolumn{3}{|c|}{10}} & \multicolumn{3}{|c|}{16} & \multirow{2}{*}{\multicolumn{3}{|c|}{$\overline{171}$}} \\
\hline Observação: & ti & dade & & $b^{*}$ & equêt & ncia a & oluta & $a(\%)$ & & & $c^{*}-F$ & qu & cia & & & & & & & & \\
\hline
\end{tabular}

Tabela 41 Local de lavagem de alimentos depois do saneamento, segundo localidades do semi-árido baiano, 2002.

\begin{tabular}{|c|c|c|c|c|c|c|c|c|c|c|c|c|c|c|c|c|c|c|c|c|c|}
\hline \multirow{3}{*}{ Origem } & \multicolumn{21}{|c|}{ Localidades } \\
\hline & \multicolumn{3}{|c|}{ Vila Cardoso } & \multicolumn{3}{|c|}{ Gameleira } & \multicolumn{3}{|c|}{ Jacunã } & \multicolumn{3}{|c|}{ Piaus } & \multicolumn{3}{|c|}{ Taquari } & \multicolumn{3}{|c|}{ Lajinha } & \multicolumn{3}{|c|}{ Total } \\
\hline & $a^{*}$ & $\mathbf{b}^{\star}$ & $c^{*}$ & $\mathbf{a}^{*}$ & $\mathbf{b}^{*}$ & $c^{*}$ & $\mathbf{a}^{*}$ & $\mathbf{b}^{\star}$ & $\mathrm{c}^{\star}$ & $a^{*}$ & $\mathbf{b}^{\star}$ & $c^{*}$ & $a^{*}$ & $\mathbf{b}^{*}$ & $c^{*}$ & $a^{*}$ & $\mathbf{b}^{*}$ & $c^{*}$ & $\mathbf{a}^{*}$ & $\mathbf{b}^{\star}$ & $c^{*}$ \\
\hline Pia de cozinha & 22 & 59,5 & 59,5 & 29 & 58,0 & 58,0 & 9 & 37,5 & 37,5 & 22 & 64,7 & 66,7 & 7 & 70,0 & 70,0 & 4 & 25,0 & 66,7 & 93 & 54,4 & 58,1 \\
\hline Bacia & 15 & 40,5 & 40,5 & 21 & 42,0 & 42,0 & 15 & 62,5 & 62,5 & 11 & 32,4 & 33,3 & 3 & 30,0 & 30,0 & 2,0 & 12,5 & 33,3 & 67 & 39,2 & 41,9 \\
\hline Total de respostas & 37 & 100,0 & 100,0 & 50 & 100,0 & 100,0 & 24 & 100,0 & 100,0 & 33 & 97,1 & 100,0 & 10 & 100,0 & 100,0 & 6 & 38 & 100,0 & 160 & 94 & $\overline{100,0}$ \\
\hline Total de entrevistados & \multicolumn{3}{|c|}{37} & \multicolumn{3}{|c|}{50} & \multirow{2}{*}{\multicolumn{3}{|c|}{$\begin{array}{r}24 \\
\text { oluta }(\%)\end{array}$}} & \multicolumn{3}{|c|}{34} & \multirow{2}{*}{\multicolumn{3}{|c|}{$\begin{array}{c}10 \\
\text { ia relativa (\%) }\end{array}$}} & \multirow{2}{*}{\multicolumn{3}{|c|}{16}} & \multirow{2}{*}{\multicolumn{3}{|c|}{171}} \\
\hline Observação: & antid & lade & & $b^{*}-F$ & Frequêr & ncia ab & & & & & $c^{\star}-F$ & requên & & & & & & & & & \\
\hline
\end{tabular}


Tabela 42 Local de lavagem de utensílios domésticos antes do saneamento, segundo localidades do semi-árido baiano, 2002.

\begin{tabular}{|c|c|c|c|c|c|c|c|c|c|c|c|c|c|c|c|c|c|c|c|c|c|}
\hline \multirow{3}{*}{ Local } & \multicolumn{21}{|c|}{ Localidades } \\
\hline & \multicolumn{3}{|c|}{ Vila Cardoso } & \multicolumn{3}{|c|}{ Gameleira } & \multicolumn{3}{|c|}{ Jacunã } & \multicolumn{3}{|c|}{ Piaus } & \multicolumn{3}{|c|}{ Taquari } & \multicolumn{3}{|c|}{ Lajinha } & \multicolumn{3}{|c|}{ Total } \\
\hline & $a^{*}$ & $\mathbf{b}^{\star}$ & $\overline{c^{*}}$ & $a^{*}$ & $\overline{b^{*}}$ & $\mathrm{c}^{\star}$ & $a^{*}$ & $\mathbf{b}^{*}$ & $\overline{c^{*}}$ & $a^{*}$ & $\mathbf{b}^{*}$ & $\overline{c^{\star}}$ & $a^{\star}$ & $\mathbf{b}^{\star}$ & $\mathrm{c}^{\star}$ & $a^{*}$ & $\mathbf{b}^{\star}$ & $\mathrm{c}^{*}$ & $a^{\star}$ & $\mathbf{b}^{\star}$ & $\overline{c^{*}}$ \\
\hline Pia & 13 & 35,1 & 29,5 & 23 & 46,0 & 46,0 & 8 & 33,3 & 32,0 & 9 & 26,5 & 22,5 & 3 & 30,0 & 27,3 & 4 & 25,0 & 15,4 & 60 & 35,1 & 30,6 \\
\hline Bacia & 24 & 64,9 & 54,5 & 27 & 54,0 & 54,0 & 16 & 66,7 & 64,0 & 25 & 73,5 & 62,5 & 6 & 60,0 & 54,5 & \begin{tabular}{|l|}
12 \\
\end{tabular} & 75,0 & 46,2 & 110 & 64,3 & 56,1 \\
\hline Tanque & 3 & 8,1 & 6,8 & - & 0,0 & 0,0 & 1 & 4,2 & 4,0 & 2 & 5,9 & 5,0 & - & 0,0 & 0,0 & - & 0,0 & 0,0 & 6 & 3,5 & 3,1 \\
\hline Rio & - & 0,0 & 0,0 & - & 0,0 & 0,0 & - & 0,0 & 0,0 & - & 0,0 & 0,0 & - & 0,0 & 0,0 & 9,0 & 56,3 & 34,6 & 9 & 5,3 & 4,6 \\
\hline Presa & 4 & 10,8 & 9,1 & - & 0,0 & 0,0 & - & 0,0 & 0,0 & 4 & 11,8 & 10,0 & 2 & 20,0 & 18,2 & - & 0,0 & 0,0 & 10 & 5,8 & 5,1 \\
\hline Rio & - & 0,0 & 0,0 & - & 0,0 & 0,0 & - & 0,0 & 0,0 & - & 0,0 & 0,0 & - & 0,0 & 0,0 & 1,0 & 6,3 & 3,8 & 1 & 0,6 & 0,5 \\
\hline Total de respostas & 44 & 118,9 & 100,0 & 50 & 100,0 & 100,0 & 25 & 104,2 & 100,0 & 40 & 117,6 & 100,0 & 11 & 110,0 & 100,0 & 26 & 163 & 100,0 & 196 & 115 & 100,0 \\
\hline Total de entrevistados & \multicolumn{3}{|c|}{37} & \multicolumn{3}{|c|}{50} & \multicolumn{3}{|c|}{24} & \multirow{2}{*}{\multicolumn{3}{|c|}{34}} & \multirow{2}{*}{\multicolumn{3}{|c|}{$\begin{array}{c}10 \\
\text { tiva }(\%)\end{array}$}} & \multirow{2}{*}{\multicolumn{3}{|c|}{16}} & \multirow{2}{*}{\multicolumn{3}{|c|}{171}} \\
\hline Observação: & antic & & & $b^{*}-$ & requê & ncia ab & 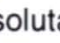 & (\%) & & & & & & & & & & & & & \\
\hline
\end{tabular}

Tabela 43 Local de lavagem de utensílios domésticos depois do saneamento, segundo localidades do semi-árido baiano, 2002.

\begin{tabular}{|c|c|c|c|c|c|c|c|c|c|c|c|c|c|c|c|c|c|c|c|c|c|}
\hline \multirow{3}{*}{ Local } & \multicolumn{21}{|c|}{ Localidades } \\
\hline & \multicolumn{3}{|c|}{ Vila Cardoso } & \multicolumn{3}{|c|}{ Gameleira } & \multicolumn{3}{|c|}{ Jacunã } & \multicolumn{3}{|c|}{ Piaus } & \multicolumn{3}{|c|}{ Taquari } & \multicolumn{3}{|c|}{ Lajinha } & \multicolumn{3}{|c|}{ Total } \\
\hline & $a^{*}$ & $\mathbf{b}^{\star}$ & $c^{*}$ & $a^{*}$ & $\mathbf{b}^{*}$ & $c^{\star}$ & $a^{*}$ & $\mathbf{b}^{\star}$ & $c^{*}$ & $a^{*}$ & $\mathbf{b}^{\star}$ & $c^{*}$ & $a^{*}$ & $\mathbf{b}^{*}$ & $c^{\star}$ & $a^{*}$ & $\mathbf{b}^{\star}$ & $c^{*}$ & $a^{*}$ & $\mathbf{b}^{*}$ & $c^{*}$ \\
\hline Pia de cozinha & 22 & 59,5 & 57,9 & 29 & 58,0 & 58,0 & 9 & 36,0 & 36,0 & 22 & 64,7 & 66,7 & 7 & 70,0 & 70,0 & 4 & 20,0 & 20,0 & 93 & 52,8 & 52,8 \\
\hline Tonel & 14 & 37,8 & 36,8 & 21 & 42,0 & 42,0 & 15 & 60,0 & 60,0 & 11 & 32,4 & 33,3 & 3 & 30,0 & 30,0 & - & 0,0 & 0,0 & 64 & 36,4 & 36,4 \\
\hline Tanque de roupa & 2 & 5,4 & 5,3 & - & 0,0 & 0,0 & 1 & 4,0 & 4,0 & - & 0,0 & 0,0 & - & 0,0 & 0,0 & - & 0,0 & 0,0 & 3 & 1,7 & 1,7 \\
\hline Bacia & - & 0,0 & 0,0 & - & 0,0 & 0,0 & - & 0,0 & 0,0 & - & 0,0 & 0,0 & - & 0,0 & 0,0 & 12 & 60,0 & 60,0 & 12 & 6,8 & 6,8 \\
\hline Rio & - & 0,0 & 0,0 & - & 0,0 & 0,0 & - & 0,0 & 0,0 & - & 0,0 & 0,0 & - & 0,0 & 0,0 & 4,0 & 20,0 & 20,0 & 4 & 2,3 & 2,3 \\
\hline Total de respostas & 38 & 102,7 & 100,0 & 50 & 100,0 & 100,0 & 25 & 100,0 & 100,0 & 33 & 97,1 & 100,0 & 10 & 100,0 & 100,0 & 20 & 100 & 100,0 & 176 & 100 & 100,0 \\
\hline Total de entrevistados & & 37 & & & 50 & & & 25 & & & 34 & & & 10 & & & 20 & & & 176 & \\
\hline
\end{tabular}


Tabela 44 Local de lavagem das mãos antes do saneamento, segundo localidades do semi-árido baiano, 2002.

\begin{tabular}{|c|c|c|c|c|c|c|c|c|c|c|c|c|c|c|c|c|c|c|c|c|c|}
\hline \multirow{3}{*}{ Local } & \multicolumn{21}{|c|}{ Localidades } \\
\hline & \multicolumn{3}{|c|}{ Vila Cardoso } & \multicolumn{3}{|c|}{ Gameleira } & \multicolumn{3}{|c|}{ Jacunã } & \multicolumn{3}{|c|}{ Piaus } & \multicolumn{3}{|c|}{ Taquari } & \multicolumn{3}{|c|}{ Lajinha } & \multicolumn{3}{|c|}{ Total } \\
\hline & $a^{*}$ & $\mathbf{b}^{\star}$ & $c^{*}$ & $a^{*}$ & $\mathbf{b}^{\star}$ & $c^{*}$ & $a^{*}$ & $\mathbf{b}^{\star}$ & $c^{\star}$ & $a^{*}$ & $\mathbf{b}^{*}$ & $c^{\star}$ & $a^{\star}$ & $\mathbf{b}^{\star}$ & $c^{\star}$ & $a^{\star}$ & $\mathbf{b}^{*}$ & $c^{*}$ & $a^{*}$ & $\mathbf{b}^{*}$ & $c^{*}$ \\
\hline Lavatório & 8 & 21,6 & 20,5 & 16 & 32,0 & 29,1 & 3 & 12,5 & 11,1 & 5 & 13,9 & 13,9 & 2 & 20,0 & 20,0 & 3 & 18,8 & 17,6 & 37 & 21,4 & 20,1 \\
\hline Bacia & 19 & 51,4 & 48,7 & 32 & 64,0 & 58,2 & 18 & 75,0 & 66,7 & 23 & 63,9 & 63,9 & 8 & 80,0 & 80,0 & 12 & 75,0 & 70,6 & 112 & 64,7 & 60,9 \\
\hline Pia de cozinha & 7 & 18,9 & 17,9 & 5 & 10,0 & 9,1 & 4 & 16,7 & 14,8 & 6 & 16,7 & 16,7 & - & 0,0 & 0,0 & 1,0 & 6,3 & 5,9 & 23 & 13,3 & 12,5 \\
\hline Tanque de roupa & 4 & 10,8 & 10,3 & 2 & 4,0 & 3,6 & 2 & 8,3 & 7,4 & 2 & 5,6 & 5,6 & - & 0,0 & 0,0 & - & 0,0 & 0,0 & 10 & 5,8 & 5,4 \\
\hline Pia e tanque & 1 & 2,7 & 2,6 & - & 0,0 & 0,0 & - & 0,0 & 0,0 & - & 0,0 & 0,0 & & 0,0 & 0,0 & 1,0 & 6,3 & 5,9 & 2 & 1,2 & 1,1 \\
\hline Total de respostas & 39 & 105,4 & 100,0 & 55 & 110,0 & 100,0 & 27 & 112,5 & 100,0 & 36 & 100,0 & 100,0 & 10 & 100,0 & 100,0 & 17 & 106 & 100,0 & 184 & 106 & 100,0 \\
\hline Total de entrevistados & \multicolumn{3}{|c|}{37} & \multicolumn{3}{|c|}{50} & \multicolumn{3}{|c|}{24} & \multirow{2}{*}{\multicolumn{3}{|c|}{36}} & \multirow{2}{*}{\multicolumn{3}{|c|}{$\begin{array}{l}10 \\
\text { iva (o }\end{array}$}} & \multirow{2}{*}{\multicolumn{3}{|c|}{16}} & \multirow{2}{*}{\multicolumn{3}{|c|}{$\overline{173}$}} \\
\hline Observação: & ntid & lade & & $b^{\star}-$ & requê & ncia at & SO। & (\%) & & & & quê & & & & & & & & & \\
\hline
\end{tabular}

Tabela 45 Local de lavagem das mãos depois do saneamento, segundo localidades do semi-árido baiano, 2002.

\begin{tabular}{|c|c|c|c|c|c|c|c|c|c|c|c|c|c|c|c|c|c|c|c|c|c|}
\hline \multirow{3}{*}{ Local } & \multicolumn{21}{|c|}{ Localidades } \\
\hline & \multicolumn{3}{|c|}{ Vila Cardoso } & \multicolumn{3}{|c|}{ Gameleira } & \multicolumn{3}{|c|}{ Jacunã } & \multicolumn{3}{|c|}{ Piaus } & \multicolumn{3}{|c|}{ Taquari } & \multicolumn{3}{|c|}{ Lajinha } & \multicolumn{3}{|c|}{ Total } \\
\hline & $a^{\star}$ & $\mathbf{b}^{\star}$ & $\mathbf{c}^{\star}$ & $a^{*}$ & $\mathbf{b}^{\star}$ & $c^{\star}$ & $a^{*}$ & $\mathbf{b}^{*}$ & $C^{*}$ & $a^{*}$ & $\mathbf{b}^{\star}$ & $c^{*}$ & $a^{*}$ & $\mathbf{b}^{\star}$ & $c^{*}$ & $a^{\star}$ & $\mathbf{b}^{\star}$ & $c^{*}$ & $a^{*}$ & $\mathbf{b}^{\star}$ & $c^{*}$ \\
\hline Lavatório & 12 & 32,4 & 30,8 & 21 & 42,0 & 38,2 & 5 & 20,8 & 20,0 & 12 & 35,3 & 30,8 & 3 & 30,0 & 30,0 & 6 & 37,5 & 35,3 & 59 & 34,5 & 31,9 \\
\hline Bacia & 10 & 27,0 & 25,6 & 22 & 44,0 & 40,0 & 14 & \begin{tabular}{|l|}
58,3 \\
\end{tabular} & 56,0 & 16 & 47,1 & 41,0 & 4 & 40,0 & 40,0 & 10 & 62,5 & 58,8 & 76 & 44,4 & 41,1 \\
\hline Tanque & 10 & 27,0 & 25,6 & 5 & 10,0 & 9,1 & 3 & 12,5 & 12,0 & 2 & 5,9 & 5,1 & - & 0,0 & 0,0 & - & 0,0 & 0,0 & 20 & 11,7 & 10,8 \\
\hline Pia de cozinha & \begin{tabular}{|l|}
7 \\
\end{tabular} & 18,9 & 17,9 & 7 & 14,0 & \begin{tabular}{l|}
12,7 \\
\end{tabular} & 3 & 12,5 & 12,0 & 9 & 26,5 & 23,1 & 3 & 30,0 & 30,0 & 1,0 & 6,3 & 5,9 & 30 & 17,5 & 16,2 \\
\hline Total de respostas & 39 & 105,4 & 100,0 & 55 & 110,0 & 100,0 & 25 & 104,2 & 100,0 & 39 & 114,7 & 100,0 & 10 & 100,0 & 100,0 & 17 & 106 & 100,0 & 185 & 108 & 100,0 \\
\hline Total de entrevistados & \multicolumn{3}{|c|}{37} & \multicolumn{3}{|c|}{50} & \multicolumn{3}{|c|}{24} & \multicolumn{3}{|c|}{36} & \multicolumn{3}{|c|}{10} & \multirow{2}{*}{\multicolumn{3}{|c|}{16}} & \multirow{2}{*}{\multicolumn{3}{|c|}{$\overline{173}$}} \\
\hline Observação: & . & ade & & & Frequêr & Itrat & 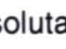 & $(\%)$ & & & $\mathrm{c}^{\star}-\mathrm{Fr}$ & 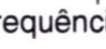 & & tiva (\% & & & & & & & \\
\hline
\end{tabular}


Tabela 46 Local de lavagem de roupas antes do saneamento, segundo localidades do semi-árido baiano, 2002.

\begin{tabular}{|c|c|c|c|c|c|c|c|c|c|c|c|c|c|c|c|c|c|c|c|c|c|}
\hline \multirow{3}{*}{ Local } & \multicolumn{21}{|c|}{ Localidades } \\
\hline & \multicolumn{3}{|c|}{ Vila Cardoso } & \multicolumn{3}{|c|}{ Gameleira } & \multicolumn{3}{|c|}{ Jacunã } & \multicolumn{3}{|c|}{ Piaus } & \multicolumn{3}{|c|}{ Taquari } & \multicolumn{3}{|c|}{ Lajinha } & \multicolumn{3}{|c|}{ Total } \\
\hline & $a^{*}$ & $\mathbf{b}^{*}$ & $\mathrm{c}^{\star}$ & $a^{*}$ & $\mathbf{b}^{\star}$ & $c^{*}$ & $a^{*}$ & $\mathbf{b}^{\star}$ & $c^{*}$ & $a^{*}$ & $\mathbf{b}^{*}$ & $c^{*}$ & $a^{*}$ & $\mathbf{b}^{*}$ & $c^{*}$ & $a^{*}$ & $\mathbf{b}^{\star}$ & $c^{*}$ & $a^{*}$ & $\mathbf{b}^{\star}$ & $\mathrm{c}^{*}$ \\
\hline Bacia & 26 & 70,3 & 45,6 & 36 & 72,0 & 45,6 & 21 & 87,5 & 48,8 & 31 & 91,2 & 47,7 & 8 & 80,0 & 47,1 & 13 & 81,3 & 43,3 & 135 & 78,9 & 46,4 \\
\hline Tanque & 11 & 29,7 & 19,3 & 19 & 38,0 & 24,1 & 3 & 12,5 & 7,0 & 3 & 8,8 & 4,6 & 1 & 10,0 & 5,9 & 3,0 & 18,8 & 10,0 & 40 & 23,4 & 13,7 \\
\hline Presa & 20 & 54,1 & 35,1 & - & 0,0 & 0,0 & - & 0,0 & 0,0 & 31 & 91,2 & 47,7 & 8 & 80,0 & 47,1 & 1,0 & 6,3 & 3,3 & 60 & 35,1 & 20,6 \\
\hline Rio & - & 0,0 & 0,0 & - & 0,0 & 0,0 & - & 0,0 & 0,0 & - & 0,0 & 0,0 & - & 0,0 & 0,0 & \begin{tabular}{|l|}
13 \\
\end{tabular} & 81,3 & 43,3 & 13 & 7,6 & 4,5 \\
\hline Fonte & - & 0,0 & 0,0 & 24 & 48,0 & 30,4 & 19 & 79,2 & 44,2 & - & 0,0 & 0,0 & - & 0,0 & 0,0 & & 0,0 & 0,0 & 43 & 25,1 & 14,8 \\
\hline Total de respostas & 57 & 154,1 & 100,0 & 79 & 158,0 & 100,0 & 43 & 179,2 & 100,0 & 65 & 191,2 & 100,0 & 17 & 170,0 & 100,0 & 30 & 188 & 100,0 & 291 & 170 & 100,0 \\
\hline Total de entrevistados & \multicolumn{3}{|c|}{37} & \multicolumn{3}{|c|}{50} & \multicolumn{3}{|c|}{24} & \multirow{2}{*}{\multicolumn{3}{|c|}{34}} & \multicolumn{3}{|c|}{10} & \multirow{2}{*}{\multicolumn{3}{|c|}{16}} & \multirow{2}{*}{\multicolumn{3}{|c|}{171}} \\
\hline Observação: & antic & & & $b^{*}-F$ & Frequê & ncia abs & 5014 & $(\%)$ & & & & quêr & & ativa $(\%$ & & & & & & & \\
\hline
\end{tabular}

Tabela 47 Local de lavagem de roupas depois do saneamento, segundo localidades do semi-árido baiano, 2002.

\begin{tabular}{|c|c|c|c|c|c|c|c|c|c|c|c|c|c|c|c|c|c|c|c|c|c|}
\hline \multirow{3}{*}{ Local } & \multicolumn{21}{|c|}{ Localidades } \\
\hline & \multicolumn{3}{|c|}{ Vila Cardoso } & \multicolumn{3}{|c|}{ Gameleira } & \multicolumn{3}{|c|}{ Jacunã } & \multicolumn{3}{|c|}{ Piaus } & \multicolumn{3}{|c|}{ Taquari } & \multicolumn{3}{|c|}{ Lajinha } & \multicolumn{3}{|c|}{ Total } \\
\hline & $a^{*}$ & $\mathbf{b}^{\star}$ & $c^{\star}$ & $a^{\star}$ & $\mathbf{b}^{*}$ & $c^{\star}$ & $a^{*}$ & $\mathbf{b}^{\star}$ & $c^{*}$ & $a^{*}$ & $\mathbf{b}^{*}$ & $c^{*}$ & $a^{\star}$ & $\mathbf{b}^{\star}$ & $c^{*}$ & $a^{*}$ & $\mathbf{b}^{*}$ & $c^{*}$ & $a^{*}$ & $\mathbf{b}^{*}$ & $c^{*}$ \\
\hline Bacia & 24 & 64,9 & 48,0 & 27 & 54,0 & 50,0 & 20 & 83,3 & 80,0 & 27 & 79,4 & 61,4 & 7 & 70,0 & 53,8 & 12 & 75,0 & 44,4 & 117 & 68,4 & 54,9 \\
\hline Tanque & 14 & 37,8 & 28,0 & 27 & 54,0 & 50,0 & 4 & 16,7 & 16,0 & 7 & 20,6 & 15,9 & 2 & 20,0 & 15,4 & 4,0 & 25,0 & 14,8 & 58 & 33,9 & 27,2 \\
\hline Presa & 12 & 32,4 & 24,0 & - & 0,0 & 0,0 & - & 0,0 & 0,0 & 10 & 29,4 & 22,7 & 4 & 40,0 & 30,8 & - & 68,8 & 40,7 & 37 & 21,6 & 17,4 \\
\hline Fonte & - & 0,0 & 0,0 & - & 0,0 & 0,0 & 1 & 4,2 & 4,0 & - & 0,0 & 0,0 & - & 0,0 & 0,0 & - & 0,0 & 0,0 & 1 & 0,6 & 0,5 \\
\hline Total de respostas & 50 & 135,1 & 100,0 & 54 & 108,0 & 100,0 & 25 & 104,2 & 100,0 & 44 & 129,4 & 100,0 & 13 & 130,0 & 100,0 & 27 & 169 & 100,0 & 213 & 125 & 100,0 \\
\hline Total de entrevistados & \multicolumn{3}{|c|}{37} & \multicolumn{3}{|c|}{50} & \multicolumn{3}{|c|}{24} & \multirow{2}{*}{\multicolumn{3}{|c|}{34}} & \multicolumn{3}{|c|}{10} & \multirow{2}{*}{\multicolumn{3}{|c|}{16}} & \multirow{2}{*}{\multicolumn{3}{|c|}{171}} \\
\hline Observação: & tid & lade & & $b^{\star}-$ & equêr & ncia al & olute & $a(\%)$ & & & & & ia & lativa ( & & & & & & & \\
\hline
\end{tabular}


Tabela 48 Local de banho antes do saneamento, segundo localidades do semi-árido baiano, 2002.

\begin{tabular}{|c|c|c|c|c|c|c|c|c|c|c|c|c|c|c|c|c|c|c|c|c|c|}
\hline \multirow{3}{*}{ Local } & \multicolumn{21}{|c|}{ Localidades } \\
\hline & \multicolumn{3}{|c|}{ Vila Cardoso } & \multicolumn{3}{|c|}{ Gameleira } & \multicolumn{3}{|c|}{ Jacunã } & \multicolumn{3}{|c|}{ Piaus } & \multicolumn{3}{|c|}{ Taquari } & \multicolumn{3}{|c|}{ Lajinha } & \multicolumn{3}{|c|}{ Total } \\
\hline & $a^{*}$ & $\mathbf{b}^{\star}$ & $c^{\star}$ & $a^{*}$ & $\mathbf{b}^{\star}$ & $c^{*}$ & $a^{*}$ & $\mathbf{b}^{\star}$ & $c^{*}$ & $a^{*}$ & $\mathbf{b}^{*}$ & $c^{*}$ & $a^{*}$ & $\mathbf{b}^{*}$ & $c^{*}$ & $a^{*}$ & $\mathbf{b}^{*}$ & $\mathrm{c}^{*}$ & $a^{*}$ & $\mathbf{b}^{*}$ & $c^{\star}$ \\
\hline Banheiro & 23 & 62,2 & 38,3 & 42 & 84,0 & 82,4 & 15 & 62,5 & 57,7 & 17 & 50,0 & 28,8 & 4 & 40,0 & 28,6 & 8 & 50,0 & 29,6 & 109 & 63,7 & 46,0 \\
\hline Banheiro do vizinho & 3 & 8,1 & 5,0 & - & 0,0 & 0,0 & 2 & 8,3 & 7,7 & - & 0,0 & 0,0 & - & 0,0 & 0,0 & - & 0,0 & 0,0 & 5 & 2,9 & 2,1 \\
\hline Bacia & 2 & 5,4 & 3,3 & - & 0,0 & 0,0 & - & 0,0 & 0,0 & 1 & 2,9 & 1,7 & - & 0,0 & 0,0 & - & 0,0 & 0,0 & 3 & 1,8 & 1,3 \\
\hline Céu aberto & 12 & 32,4 & 20,0 & 8 & 16,0 & 15,7 & 9 & 37,5 & 34,6 & 16 & 47,1 & 27,1 & 4 & 40,0 & 28,6 & 7,0 & 43,8 & 25,9 & 56 & 32,7 & 23,6 \\
\hline Rio & - & 0,0 & 0,0 & - & 0,0 & 0,0 & - & 0,0 & 0,0 & - & 0,0 & 0,0 & - & 0,0 & 0,0 & \begin{tabular}{|l|}
12 \\
\end{tabular} & 75,0 & 44,4 & 12 & 7,0 & 5,1 \\
\hline Presa & 20 & 54,1 & 33,3 & - & 0,0 & 0,0 & - & 0,0 & 0,0 & 25 & 73,5 & 42,4 & 6 & 60,0 & 42,9 & - & 0,0 & 0,0 & 51 & 29,8 & 21,5 \\
\hline Fonte & - & 0,0 & 0,0 & 1 & 2,0 & 2,0 & - & 0,0 & 0,0 & - & 0,0 & 0,0 & - & 0,0 & 0,0 & - & 0,0 & 0,0 & 1 & 0,6 & 0,4 \\
\hline Total de respostas & 60 & 162,2 & 100,0 & 51 & 102,0 & 100,0 & 26 & 108,3 & 100,0 & 59 & 173,5 & 100,0 & 14 & 140,0 & 100,0 & 27 & 168,8 & 100,0 & 237 & 138,6 & 100,0 \\
\hline Total de entrevistados & \multicolumn{3}{|c|}{37} & \multicolumn{3}{|c|}{50} & \multirow{2}{*}{\multicolumn{3}{|c|}{24}} & \multirow{2}{*}{\multicolumn{3}{|c|}{34}} & \multirow{2}{*}{\multicolumn{3}{|c|}{$\begin{array}{c}10 \\
\text { tiva (\%) }\end{array}$}} & \multirow{2}{*}{\multicolumn{3}{|c|}{16}} & \multirow{2}{*}{\multicolumn{3}{|c|}{171}} \\
\hline Observação: & atic & & & 0 & equêr & ncia abs & & & & & & quêr & & & & & & & & & \\
\hline
\end{tabular}

Tabela 49 Local de banho depois do saneamento, segundo localidades do semi-árido baiano, 2002.

\begin{tabular}{|c|c|c|c|c|c|c|c|c|c|c|c|c|c|c|c|c|c|c|c|c|c|}
\hline \multirow{3}{*}{ Local } & \multicolumn{21}{|c|}{ Localidades } \\
\hline & \multicolumn{3}{|c|}{ Vila Cardoso } & \multicolumn{3}{|c|}{ Gameleira } & \multicolumn{3}{|c|}{ Jacunã } & \multicolumn{3}{|c|}{ Piaus } & \multicolumn{3}{|c|}{ Taquari } & \multicolumn{3}{|c|}{ Lajinha } & \multicolumn{3}{|c|}{ Total } \\
\hline & $a^{*}$ & $\mathbf{b}^{*}$ & $c^{*}$ & $a^{*}$ & $\mathbf{b}^{*}$ & $c^{*}$ & $a^{*}$ & $\mathbf{b}^{*}$ & $c^{*}$ & $a^{*}$ & $\mathbf{b}^{*}$ & $c^{*}$ & $a^{\star}$ & $\mathbf{b}^{*}$ & $c^{*}$ & $a^{*}$ & $\mathbf{b}^{*}$ & $c^{\star}$ & $a^{*}$ & $\mathbf{b}^{*}$ & $c^{*}$ \\
\hline Banheiro & 33 & 89,2 & 86,8 & 50 & 100,0 & 100,0 & 22 & 91,7 & 91,7 & 33 & 97,1 & 91,7 & 9 & 90,0 & 90,0 & 14 & 87,5 & 77,8 & 161 & 94,2 & 91,5 \\
\hline Céu aberto & 4 & 10,8 & 10,5 & - & 0,0 & 0,0 & 1 & 4,2 & 4,2 & 1 & 2,9 & 2,8 & - & 0,0 & 0,0 & 2,0 & 12,5 & 11,1 & 8 & 4,7 & 4,5 \\
\hline Presa & 1 & 2,7 & 2,6 & - & 0,0 & 0,0 & 1 & 4,2 & 4,2 & 2 & 5,9 & 5,6 & 1 & 10,0 & 10,0 & & 0,0 & 0,0 & 5 & 2,9 & 2,8 \\
\hline Rio & - & 0,0 & 0,0 & - & 0,0 & 0,0 & - & 0,0 & 0,0 & - & 0,0 & 0,0 & - & 0,0 & 0,0 & 2,0 & 12,5 & 11,1 & 2 & 1,2 & 1,1 \\
\hline Total de respostas & 38 & 102,7 & 100,0 & 50 & 100,0 & 100,0 & 24 & 100,0 & 100,0 & 36 & 105,9 & 100,0 & 10 & 100,0 & 100,0 & 18 & 112,5 & 100,0 & 176 & 103 & 100,0 \\
\hline Total de entrevistados & \multicolumn{3}{|c|}{37} & \multicolumn{3}{|c|}{50} & \multirow{2}{*}{\multicolumn{3}{|c|}{$\begin{array}{r}24 \\
\text { soluta }(\%)\end{array}$}} & \multirow{2}{*}{\multicolumn{3}{|c|}{34}} & \multirow{2}{*}{\multicolumn{3}{|c|}{$\begin{array}{c}10 \\
\text { tiva }(\%)\end{array}$}} & \multirow{2}{*}{\multicolumn{3}{|c|}{16}} & \multirow{2}{*}{\multicolumn{3}{|c|}{171}} \\
\hline Observação: & inti & ade & & $b^{\star}$ & Frequêr & ncia ab & & & & & & & & & & & & & & & \\
\hline
\end{tabular}


Tabela 50 Local de utilizado para defecar antes do saneamento, segundo localidades do semi-árido baiano, 2002.

\begin{tabular}{|c|c|c|c|c|c|c|c|c|c|c|c|c|c|c|c|c|c|c|c|c|c|}
\hline \multirow{3}{*}{ Local } & \multicolumn{21}{|c|}{ Localidades } \\
\hline & \multicolumn{3}{|c|}{ Vila Cardoso } & \multicolumn{3}{|c|}{ Gameleira } & \multicolumn{3}{|c|}{ Jacunã } & \multicolumn{3}{|c|}{ Piaus } & \multicolumn{3}{|c|}{ Taquari } & \multicolumn{3}{|c|}{ Lajinha } & \multicolumn{3}{|c|}{ Total } \\
\hline & $a^{*}$ & $\mathbf{b}^{*}$ & $c^{*}$ & $a^{*}$ & $\mathbf{b}^{\star}$ & $c^{*}$ & $a^{*}$ & $\mathbf{b}^{*}$ & $c^{\star}$ & $a^{\star}$ & $\mathbf{b}^{\star}$ & $c^{*}$ & $a^{*}$ & $\mathbf{b}^{\star}$ & $c^{*}$ & $a^{*}$ & $\mathbf{b}^{*}$ & $c^{*}$ & $a^{*}$ & $\mathbf{b}^{*}$ & $c^{*}$ \\
\hline Sanitário & 28 & 75,7 & 68,3 & 43 & 86,0 & 76,8 & 14 & 58,3 & 56,0 & 25 & 73,5 & 59,5 & 6 & 60,0 & 42,9 & 12 & 75,0 & 63,2 & 128 & 74,9 & 65,0 \\
\hline Sanitário do vizinho & 2 & 5,4 & 4,9 & - & 0,0 & 0,0 & 3 & 12,5 & 12,0 & 1 & 2,9 & 2,4 & - & 0,0 & 0,0 & - & 0,0 & 0,0 & 6 & 3,5 & 3,0 \\
\hline Mato & 4 & 10,8 & 9,8 & 6 & 12,0 & 10,7 & 2 & 8,3 & 8,0 & 7 & 20,6 & 16,7 & 4 & 40,0 & 28,6 & 3,0 & 18,8 & 15,8 & 26 & 15,2 & 13,2 \\
\hline Fossa Seca & 1 & 2,7 & 2,4 & - & 0,0 & 0,0 & 1 & 4,2 & 4,0 & 1 & 2,9 & 2,4 & - & 0,0 & 0,0 & 1,0 & 6,3 & 5,3 & 4 & 2,3 & 2,0 \\
\hline $\begin{array}{c}\text { Recipiente e joga fora } \\
\text { (balão) }\end{array}$ & 6 & 16,2 & 14,6 & 5 & 10,0 & 8,9 & 4 & 16,7 & 16,0 & 8 & 23,5 & 19,0 & 4 & 40,0 & 28,6 & 3,0 & 18,8 & 15,8 & 30 & 17,5 & 15,2 \\
\hline Buraco no chão & - & 0,0 & 0,0 & 2 & 4,0 & 3,6 & 1 & 4,2 & 4,0 & - & 0,0 & 0,0 & - & 0,0 & 0,0 & - & 0,0 & 0,0 & 3 & 1,8 & 1,5 \\
\hline Total de respostas & 41 & 110,8 & 100,0 & 56 & 112,0 & 100,0 & 25 & 104,2 & 100,0 & 42 & 123,5 & 100,0 & 14 & 140,0 & 100,0 & 19 & 118,8 & 100,0 & 197 & 115,2 & 100,0 \\
\hline Total de entrevistados & \multicolumn{3}{|c|}{37} & \multicolumn{3}{|c|}{50} & \multicolumn{3}{|c|}{24} & \multicolumn{3}{|c|}{34} & \multicolumn{3}{|c|}{10} & \multirow{2}{*}{\multicolumn{3}{|c|}{16}} & \multirow{2}{*}{\multicolumn{3}{|c|}{171}} \\
\hline Observação: & ntic & & & $b^{*}-F$ & Frequêr & ncia at & 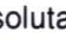 & a (\%) & & & $c^{*}-F$ & quế & a & ativa & & & & & & & \\
\hline
\end{tabular}

Tabela 51 Local de utilizado para defecar antes do saneamento, segundo localidades do semi-árido baiano, 2002.

\begin{tabular}{|c|c|c|c|c|c|c|c|c|c|c|c|c|c|c|c|c|c|c|c|c|c|}
\hline \multirow{3}{*}{ Local } & \multicolumn{21}{|c|}{ Localidades } \\
\hline & \multicolumn{3}{|c|}{ Vila Cardoso } & \multicolumn{3}{|c|}{ Gameleira } & \multicolumn{3}{|c|}{ Jacunã } & \multicolumn{3}{|c|}{ Piaus } & \multicolumn{3}{|c|}{ Taquari } & \multicolumn{3}{|c|}{ Lajinha } & \multicolumn{3}{|c|}{ Total } \\
\hline & $a^{\star}$ & $\mathbf{b}^{\star}$ & $\mathbf{c}^{\star}$ & $a^{*}$ & $\mathbf{b}^{\star}$ & $c^{*}$ & $a^{*}$ & $\mathbf{b}^{\star}$ & $c^{\star}$ & $a^{*}$ & $\mathbf{b}^{*}$ & $c^{\star}$ & $a^{\star}$ & $\mathbf{b}^{*}$ & $c^{*}$ & $a^{*}$ & $\mathbf{b}^{\star}$ & $c^{*}$ & $a^{\star}$ & $\mathbf{b}^{*}$ & $\mathrm{c}^{\star}$ \\
\hline Sanitário & 35 & 94,6 & 89,7 & 50 & 100,0 & 98,0 & 22 & 91,7 & \begin{tabular}{|l|}
91,7 \\
\end{tabular} & 34 & 100,0 & 100,0 & \begin{tabular}{|c|}
10 \\
\end{tabular} & 100,0 & 100,0 & 15 & 88,2 & 88,2 & 166 & 96,5 & 94,9 \\
\hline Mato & 2 & 5,4 & 5,1 & 1 & 2,0 & 2,0 & - & 0,0 & 0,0 & - & 0,0 & 0,0 & - & 0,0 & 0,0 & 1,0 & 5,9 & 5,9 & 4 & 2,3 & 2,3 \\
\hline $\begin{array}{l}\text { Recipiente e joga fora } \\
\text { (balão) }\end{array}$ & 2 & 5,4 & 5,1 & - & 0,0 & 0,0 & - & 0,0 & 0,0 & - & 0,0 & 0,0 & - & 0,0 & 0,0 & 1,0 & 5,9 & 5,9 & 3 & 1,7 & 1,7 \\
\hline Casa do vizinho & - & 0,0 & 0,0 & - & 0,0 & 0,0 & 1 & 4,2 & 4,2 & - & 0,0 & 0,0 & - & 0,0 & 0,0 & - & 0,0 & 0,0 & 1 & 0,6 & 0,6 \\
\hline Buraco no chão & - & 0,0 & 0,0 & - & 0,0 & 0,0 & 1 & 4,2 & 4,2 & - & 0,0 & 0,0 & - & 0,0 & 0,0 & - & 0,0 & 0,0 & 1 & 0,6 & 0,6 \\
\hline Total de respostas & 39 & 105,4 & 100,0 & 51 & 102,0 & 100,0 & 24 & 100,0 & 100,0 & 34 & 100,0 & 100,0 & 10 & 100,0 & 100,0 & 17 & 100 & 100,0 & 175 & 102 & 100,0 \\
\hline Total de entrevistados & & 37 & & & 50 & & & 24 & & & 34 & & & 10 & & & 17 & & & 172 & \\
\hline
\end{tabular}




\section{Apêndice D Tabelas 52 a 71}

Tabela 52 Frequência de armazenamento da água antes do saneamento, segundo níveis de saneamento e localidades do semi-árido baiano, 2002.

\begin{tabular}{|c|c|c|c|c|c|c|c|c|}
\hline \multicolumn{2}{|c|}{ Nível } & Vila Cardoso & Gameleira & Jacunã & Piaus & Taquari & Lajinha & Média \\
\hline \multirow[b]{2}{*}{1} & Quant. & 6 & 3 & 0 & 0 & 2 & 2 & 13 \\
\hline & $\%$ & 16,2 & 6,1 & 0,0 & 0,0 & 20,0 & 12,5 & 7,6 \\
\hline \multirow[b]{2}{*}{2} & Quant & 7 & 5 & 2 & 5 & 2 & 1 & 22 \\
\hline & $\%$ & 18,9 & 10,2 & 8,3 & 14,7 & 20,0 & 6,3 & 12,9 \\
\hline \multirow{3}{*}{3} & Quant & 24 & 41 & 22 & 29 & 6 & 13 & 135 \\
\hline & $\%$ & 64,9 & 83,7 & 91,7 & 85,3 & 60,0 & 81,3 & 79,4 \\
\hline & Quant & 37 & 49 & 24 & 34 & 10 & 16 & 170 \\
\hline TOTAL & $\%$ & 100,0 & 100,0 & 100,0 & 100,0 & 100,0 & 100,0 & 100,0 \\
\hline
\end{tabular}

Tabela 53 Frequência de armazenamento da água depois do saneamento, segundo níveis de saneamento e localidades do semi-árido baiano, 2002.

\begin{tabular}{c|l|c|c|c|c|c|c|c}
\hline Nível & & Vila Cardoso & Gameleira & Jacunã & Piaus & Taquari & Lajinha & Média \\
\hline \multirow{3}{*}{1} & Quant & 21 & 37 & 8 & 17 & 8 & 16 & 107 \\
\cline { 2 - 9 } & $\%$ & 56,8 & 75,5 & 33,3 & 50,0 & 80,0 & 100,0 & $\mathbf{6 2 , 9}$ \\
\hline \multirow{3}{*}{2} & Quant & 4 & 10 & 4 & 9 & & & 27 \\
\cline { 2 - 9 } 3 & 10,8 & 20,4 & 16,7 & 26,5 & 0,0 & 0,0 & $\mathbf{1 5 , 9}$ \\
\hline \multirow{3}{*}{3} & Quant & 12 & 2 & 12 & 8 & 2 & 0 & 36 \\
\cline { 2 - 9 } TOTAL & 32,4 & 4,1 & 50,0 & 23,5 & 20,0 & 0,0 & $\mathbf{2 1 , 2}$ \\
\cline { 2 - 9 } & Quant & $\mathbf{3 7}$ & $\mathbf{4 9}$ & $\mathbf{2 4}$ & $\mathbf{3 4}$ & $\mathbf{1 0}$ & $\mathbf{1 6}$ & $\mathbf{1 7 0}$ \\
\hline \multirow{2}{*}{} & $\mathbf{1 0 0 , 0}$ & $\mathbf{1 0 0 , 0}$ & $\mathbf{1 0 0 , 0}$ & $\mathbf{1 0 0 , 0}$ & $\mathbf{1 0 0 , 0}$ & $\mathbf{1 0 0 , 0}$ & $\mathbf{1 0 0 , 0}$
\end{tabular}

Tabela 54 Frequência de origem da água de beber antes do saneamento, segundo níveis de saneamento e localidades do semi-árido baiano, 2002.

\begin{tabular}{c|c|c|c|c|c|c|c|c}
\hline \multicolumn{2}{c|}{ Nível } & Vila Cardoso & Gameleira & Jacunã & Piaus & Taquari & Lajinha & Média \\
\hline \multirow{3}{*}{1} & Quant & 1 & 0 & 0 & 0 & 0 & 2 & 3 \\
\cline { 2 - 9 } & $\%$ & 2,7 & 0,0 & 0,0 & 0,0 & 0,0 & 12,5 & $\mathbf{1 , 8}$ \\
\hline \multirow{3}{*}{2} & Quant & 8 & 50 & 24 & 28 & 6 & 1 & 117 \\
\cline { 2 - 9 } & $\%$ & 21,6 & 100,0 & 100,0 & 82,4 & 60,0 & 6,3 & $\mathbf{6 8 , 4}$ \\
\hline \multirow{3}{*}{3} & Quant & 28 & 0 & 0 & 6 & 4 & 13 & 51 \\
\cline { 2 - 9 } & $\%$ & 75,7 & 0,0 & 0,0 & 17,6 & 40,0 & 81,3 & $\mathbf{2 9 , 8}$ \\
\hline \multirow{2}{*}{ TOTAL } & Quant & $\mathbf{3 7}$ & $\mathbf{5 0}$ & $\mathbf{2 4}$ & $\mathbf{3 4}$ & $\mathbf{1 0}$ & $\mathbf{1 6}$ & $\mathbf{1 7 1}$ \\
\cline { 2 - 10 } & $\mathbf{1 0 0 , 0}$ & $\mathbf{1 0 0 , 0}$ & $\mathbf{1 0 0 , 0}$ & $\mathbf{1 0 0 , 0}$ & $\mathbf{1 0 0 , 0}$ & $\mathbf{1 0 0 , 0}$ & $\mathbf{1 0 0 , 0}$
\end{tabular}

Tabela 55 Frequência de origem da água de beber depois do saneamento, segundo níveis de saneamento e localidades do semi-árido baiano, 2002.

\begin{tabular}{c|l|c|c|c|c|c|c|c}
\hline \multicolumn{2}{c|}{ Nível } & Vila Cardoso & Gameleira & Jacunã & Piaus & Taquari & Lajinha & Média \\
\hline \multirow{3}{*}{1} & Quant & 20 & 47 & 22 & 16 & 8 & 15 & 128 \\
\cline { 2 - 9 } & $\%$ & 54,1 & 94,0 & 91,7 & 47,1 & 80,0 & 93,8 & $\mathbf{7 4 , 9}$ \\
\hline \multirow{3}{*}{2} & Quant & 4 & 1 & 0 & 4 & 2 & 0 & 11 \\
\cline { 2 - 9 } & $\%$ & 10,8 & 2,0 & 0,0 & 11,8 & 20,0 & 0,0 & $\mathbf{6 , 4}$ \\
\hline \multirow{3}{*}{3} & Quant & 13 & 2 & 2 & 14 & 0 & 1 & 32 \\
\cline { 2 - 9 } & $\%$ & 35,1 & 4,0 & 8,3 & 41,2 & 0,0 & 6,3 & $\mathbf{1 8 , 7}$ \\
\hline \multirow{2}{*}{ TOTAL } & Quant & $\mathbf{3 7}$ & $\mathbf{5 0}$ & $\mathbf{2 4}$ & $\mathbf{3 4}$ & $\mathbf{1 0}$ & $\mathbf{1 6}$ & $\mathbf{1 7 1}$ \\
\cline { 2 - 9 } & $\mathbf{1 0 0 , 0}$ & $\mathbf{1 0 0 , 0}$ & $\mathbf{1 0 0 , 0}$ & $\mathbf{1 0 0 , 0}$ & $\mathbf{1 0 0 , 0}$ & $\mathbf{1 0 0 , 0}$ & $\mathbf{1 0 0 , 0}$
\end{tabular}


Tabela 56 Frequência de tipo de tratamento de água antes do saneamento, segundo níveis de saneamento e localidades do semi-árido baiano, 2002.

\begin{tabular}{c|c|c|c|c|c|c|c|c}
\hline \multicolumn{2}{c|}{ Nível } & Vila Cardoso & Gameleira & Jacunã & Piaus & Taquari & Lajinha & Média \\
\hline \multirow{3}{*}{1} & Quant & 0 & 0 & 0 & 0 & 0 & 0 & 0 \\
\cline { 2 - 9 } & $\%$ & 0,0 & 0,0 & 0,0 & 0,0 & 0,0 & 0,0 & $\mathbf{0 , 0}$ \\
\hline \multirow{3}{*}{2} & Quant & 37 & 50 & 24 & 34 & 10 & 15 & 170 \\
\cline { 2 - 9 } & $\%$ & 100,0 & 100,0 & 100,0 & 100,0 & 100,0 & 100,0 & $\mathbf{1 0 0 , 0}$ \\
\hline \multirow{3}{*}{3} & Quant & 0 & 0 & 0 & 0 & 0 & 0 & 0 \\
\hline \multirow{2}{*}{ TOTAL } & 0,0 & 0,0 & 0,0 & 0,0 & 0,0 & 0,0 & $\mathbf{0 , 0}$ \\
\cline { 2 - 9 } & Quant & $\mathbf{3 7}$ & $\mathbf{5 0}$ & $\mathbf{2 4}$ & $\mathbf{3 4}$ & $\mathbf{1 0}$ & $\mathbf{1 5}$ & $\mathbf{1 7 0}$ \\
\cline { 2 - 9 } & $\mathbf{1 0 0 , 0}$ & $\mathbf{1 0 0 , 0}$ & $\mathbf{1 0 0 , 0}$ & $\mathbf{1 0 0 , 0}$ & $\mathbf{1 0 0 , 0}$ & $\mathbf{1 0 0 , 0}$ & $\mathbf{1 0 0 , 0}$
\end{tabular}

Tabela 57 Frequência de tipo de tratamento de água depois do saneamento, segundo níveis de saneamento e localidades do semi-árido baiano, 2002.

\begin{tabular}{c|c|c|c|c|c|c|c|c}
\hline \multicolumn{2}{c|}{ Nível } & Vila Cardoso & Gameleira & Jacunã & Piaus & Taquari & Lajinha & Média \\
\hline \multirow{3}{*}{1} & Quant & 29 & 21 & 20 & 21 & 7 & 5 & 103 \\
\cline { 2 - 9 } & $\%$ & 78,4 & 42,0 & 83,3 & 63,6 & 70,0 & 33,3 & $\mathbf{6 0 , 9}$ \\
\hline \multirow{3}{*}{2} & Quant & 8 & 29 & 4 & 12 & 3 & 10 & 66 \\
\cline { 2 - 9 } & $\%$ & 21,6 & 58,0 & 16,7 & 36,4 & 30,0 & 66,7 & $\mathbf{3 9 , 1}$ \\
\hline \multirow{3}{*}{3} & Quant & 0 & 0 & 0 & 0 & 0 & 0 & 0 \\
\cline { 2 - 9 } & $\%$ & 0,0 & 0,0 & 0,0 & 0,0 & 0,0 & 0,0 & $\mathbf{0 , 0}$ \\
\hline \multirow{2}{*}{ TOTAL } & Quant & $\mathbf{3 7}$ & $\mathbf{5 0}$ & $\mathbf{2 4}$ & $\mathbf{3 3}$ & $\mathbf{1 0}$ & $\mathbf{1 5}$ & $\mathbf{1 6 9}$ \\
\cline { 2 - 9 } & $\mathbf{1 0 0 , 0}$ & $\mathbf{1 0 0 , 0}$ & $\mathbf{1 0 0 , 0}$ & $\mathbf{1 0 0 , 0}$ & $\mathbf{1 0 0 , 0}$ & $\mathbf{1 0 0 , 0}$ & $\mathbf{1 0 0 , 0}$
\end{tabular}

Tabela 58 Frequência de local de lavagem de alimentos antes do saneamento, segundo níveis de saneamento e localidades do semi-árido baiano, 2002.

\begin{tabular}{c|c|c|c|c|c|c|c|c}
\hline \multicolumn{2}{c|}{ Nível } & Vila Cardoso & Gameleira & Jacunã & Piaus & Taquari & Lajinha & Média \\
\hline \multirow{2}{*}{1} & Quant & 13 & 22 & 7 & 9 & 3 & 4 & 58 \\
\cline { 2 - 9 } & $\%$ & 17,6 & 22,0 & 14,6 & 13,2 & 15,0 & 12,5 & $\mathbf{1 7 , 0}$ \\
\hline \multirow{3}{*}{2} & Quant & 24 & 28 & 17 & 25 & 7 & 12 & 113 \\
\cline { 2 - 9 } & $\%$ & 32,4 & 28,0 & 35,4 & 36,8 & 35,0 & 37,5 & $\mathbf{3 3 , 0}$ \\
\hline \multirow{3}{*}{3} & Quant & 37 & 50 & 24 & 34 & 10 & 16 & 171 \\
\cline { 2 - 9 } & $\%$ & 50,0 & 50,0 & 50,0 & 50,0 & 50,0 & 50,0 & $\mathbf{5 0 , 0}$ \\
\hline \multirow{2}{*}{ TOTAL } & Quant & $\mathbf{7 4}$ & $\mathbf{1 0 0}$ & $\mathbf{4 8}$ & $\mathbf{6 8}$ & $\mathbf{2 0}$ & $\mathbf{3 2}$ & $\mathbf{3 4 2}$ \\
\cline { 2 - 9 } & $\mathbf{1 0 0 , 0}$ & $\mathbf{1 0 0 , 0}$ & $\mathbf{1 0 0 , 0}$ & $\mathbf{1 0 0 , 0}$ & $\mathbf{1 0 0 , 0}$ & $\mathbf{1 0 0 , 0}$ & $\mathbf{1 0 0 , 0}$
\end{tabular}

Tabela 59 Frequência de local de lavagem de alimentos depois do saneamento, segundo níveis de saneamento e localidades do semi-árido baiano, 2002.

\begin{tabular}{|c|c|c|c|c|c|c|c|c|}
\hline \multicolumn{2}{|c|}{ Nível } & Vila Cardoso & Gameleira & Jacunã & Piaus & Taquari & Lajinha & Média \\
\hline \multirow[b]{2}{*}{1} & Quant & 22 & 29 & 9 & 22 & 7 & 4 & 93 \\
\hline & $\%$ & 59,5 & 58,0 & 37,5 & 64,7 & 70,0 & 25,0 & 54,4 \\
\hline \multirow[b]{2}{*}{2} & Quant & 15 & 21 & 15 & 12 & 3 & 12 & 78 \\
\hline & $\%$ & 40,5 & 42,0 & 62,5 & 35,3 & 30,0 & 75,0 & 45,6 \\
\hline \multirow[b]{2}{*}{3} & Quant & 0 & 0 & 0 & 0 & 0 & 0 & 0 \\
\hline & $\%$ & 0,0 & 0,0 & 0,0 & 0,0 & 0,0 & 0,0 & 0,0 \\
\hline & Quant & 37 & 50 & 24 & 34 & 10 & 16 & 171 \\
\hline $1 \mathrm{~A}$ & $\%$ & 100,0 & 100,0 & 100,0 & 100,0 & 100,0 & 100,0 & 100,0 \\
\hline
\end{tabular}


Tabela 60 Frequência de local de lavagem dos utensílios domésticos antes do saneamento, segundo níveis de saneamento e localidades do semi-árido baiano, 2002.

\begin{tabular}{c|c|c|c|c|c|c|c|c}
\hline \multicolumn{2}{c|}{ Nível } & Vila Cardoso & Gameleira & Jacunã & Piaus & Taquari & Lajinha & Média \\
\hline \multirow{2}{*}{1} & Quant & 13 & 23 & 8 & 9 & 3 & 3 & 59 \\
\cline { 2 - 9 } & $\%$ & 35,1 & 46,0 & 33,3 & 26,5 & 30,0 & 18,8 & $\mathbf{3 4 , 5}$ \\
\hline \multirow{3}{*}{2} & Quant & 20 & 27 & 16 & 21 & 5 & 3 & 92 \\
\cline { 2 - 9 } & $\%$ & 54,1 & 54,0 & 66,7 & 61,8 & 50,0 & 18,8 & $\mathbf{5 3 , 8}$ \\
\hline \multirow{3}{*}{3} & Quant & 4 & 0 & 0 & 4 & 2 & 10 & 20 \\
\cline { 2 - 9 } TOTAL & 10,8 & 0,0 & 0,0 & 11,8 & 20,0 & 62,5 & $\mathbf{1 1 , 7}$ \\
\cline { 2 - 9 } & $\%$ & $\mathbf{3 7}$ & $\mathbf{5 0}$ & $\mathbf{2 4}$ & $\mathbf{3 4}$ & $\mathbf{1 0}$ & $\mathbf{1 6}$ & $\mathbf{1 7 1}$ \\
\hline \multirow{2}{*}{ Quant } & $\mathbf{1 0 0 , 0}$ & $\mathbf{1 0 0 , 0}$ & $\mathbf{1 0 0 , 0}$ & $\mathbf{1 0 0 , 0}$ & $\mathbf{1 0 0 , 0}$ & $\mathbf{1 0 0 , 0}$ & $\mathbf{1 0 0 , 0}$
\end{tabular}

Tabela 61 Frequência de local de lavagem dos utensílios domésticos depois do saneamento, segundo níveis de saneamento e localidades do semi-árido baiano, 2002.

\begin{tabular}{c|c|c|c|c|c|c|c|c}
\hline \multicolumn{2}{c|}{ Nível } & Vila Cardoso & Gameleira & Jacunã & Piaus & Taquari & Lajinha & Média \\
\hline \multirow{3}{*}{1} & Quant & 23 & 29 & 9 & 22 & 7 & 3 & 93 \\
\cline { 2 - 9 } & $\%$ & 62,2 & 58,0 & 37,5 & 64,7 & 70,0 & 18,8 & $\mathbf{5 4 , 4}$ \\
\hline \multirow{3}{*}{2} & Quant & 14 & 21 & 15 & 12 & 3 & 9 & 74 \\
\cline { 2 - 9 } & $\%$ & 37,8 & 42,0 & 62,5 & 35,3 & 30,0 & 56,3 & $\mathbf{4 3 , 3}$ \\
\hline \multirow{3}{*}{3} & Quant & 0 & 0 & 0 & 0 & 0 & 4 & 4 \\
\cline { 2 - 9 } TOTAL & 0,0 & 0,0 & 0,0 & 0,0 & 0,0 & 25,0 & $\mathbf{2 , 3}$ \\
\cline { 2 - 10 } & $\%$ & $\mathbf{3 7}$ & $\mathbf{5 0}$ & $\mathbf{2 4}$ & $\mathbf{3 4}$ & $\mathbf{1 0}$ & $\mathbf{1 6}$ & $\mathbf{1 7 1}$ \\
\hline \multirow{2}{*}{$\mathbf{1 0 0 , 0}$} & $\mathbf{1 0 0 , 0}$ & $\mathbf{1 0 0 , 0}$ & $\mathbf{1 0 0 , 0}$ & $\mathbf{1 0 0 , 0}$ & $\mathbf{1 0 0 , 0}$ & $\mathbf{1 0 0 , 0}$
\end{tabular}

Tabela 62 Frequência de local de lavagem das mãos antes do saneamento, segundo níveis de saneamento e localidades do semi-árido baiano, 2002.

\begin{tabular}{c|l|c|c|c|c|c|c|c}
\hline \multicolumn{2}{c|}{ Nível } & Vila Cardoso & Gameleira & Jacunã & Piaus & Taquari & Lajinha & Média \\
\hline \multirow{3}{*}{1} & Quant & 18 & 18 & 6 & 11 & 2 & 4 & 59 \\
\cline { 2 - 9 } & $\%$ & 48,6 & 36,0 & 25,0 & 32,4 & 20,0 & 25,0 & $\mathbf{3 4 , 5}$ \\
\hline \multirow{3}{*}{2} & Quant & 19 & 32 & 18 & 23 & 8 & 12 & 112 \\
\cline { 2 - 9 } & $\%$ & 51,4 & 64,0 & 75,0 & 67,6 & 80,0 & 75,0 & $\mathbf{6 5 , 5}$ \\
\hline \multirow{3}{*}{3} & Quant & 0 & 0 & 0 & 0 & 0 & 0 & 0 \\
\cline { 2 - 9 } TOTAL & 0,0 & 0,0 & 0,0 & 0,0 & 0,0 & 0,0 & $\mathbf{0 , 0}$ \\
\cline { 2 - 10 } & $\%$ & $\mathbf{3 7}$ & $\mathbf{5 0}$ & $\mathbf{2 4}$ & $\mathbf{3 4}$ & $\mathbf{1 0}$ & $\mathbf{1 6}$ & $\mathbf{1 7 1}$ \\
\hline \multirow{2}{*}{ Quant } & $\mathbf{1 0 0 , 0}$ & $\mathbf{1 0 0 , 0}$ & $\mathbf{1 0 0 , 0}$ & $\mathbf{1 0 0 , 0}$ & $\mathbf{1 0 0 , 0}$ & $\mathbf{1 0 0 , 0}$ & $\mathbf{1 0 0 , 0}$
\end{tabular}

Tabela 63 Frequência de local de lavagem das mãos depois do saneamento, segundo níveis de saneamento e localidades do semi-árido baiano, 2002.

\begin{tabular}{c|l|c|c|c|c|c|c|c}
\hline \multicolumn{2}{c|}{ Nível } & Vila Cardoso & Gameleira & Jacunã & Piaus & Taquari & Lajinha & Média \\
\hline \multirow{3}{*}{1} & Quant & 22 & 26 & 8 & 14 & 3 & 6 & 79 \\
\cline { 2 - 9 } & $\%$ & 68,8 & 54,2 & 36,4 & 46,7 & 42,9 & 37,5 & $\mathbf{5 1 , 0}$ \\
\hline \multirow{3}{*}{2} & Quant & 10 & 22 & 14 & 16 & 4 & 10 & 76 \\
\cline { 2 - 9 } & $\%$ & 31,3 & 45,8 & 63,6 & 53,3 & 57,1 & 62,5 & $\mathbf{4 9 , 0}$ \\
\hline \multirow{3}{*}{3} & Quant & 0 & & 0 & 0 & 0 & & 0 \\
\cline { 2 - 9 } TOTAL & 0,0 & 0,0 & 0,0 & 0,0 & 0,0 & 0,0 & $\mathbf{0 , 0}$ \\
\cline { 2 - 9 } & Quant & $\mathbf{3 2}$ & $\mathbf{4 8}$ & $\mathbf{2 2}$ & $\mathbf{3 0}$ & $\mathbf{7}$ & $\mathbf{1 6}$ & $\mathbf{1 5 5}$ \\
\cline { 2 - 9 } & $\mathbf{1 0 0 , 0}$ & $\mathbf{1 0 0 , 0}$ & $\mathbf{1 0 0 , 0}$ & $\mathbf{1 0 0 , 0}$ & $\mathbf{1 0 0 , 0}$ & $\mathbf{1 0 0 , 0}$ & $\mathbf{1 0 0 , 0}$
\end{tabular}


Tabela 64 Frequência de local de lavagem das roupas antes do saneamento, segundo níveis de saneamento e localidades do semi-árido baiano, 2002.

\begin{tabular}{c|l|c|c|c|c|c|c|c}
\hline \multicolumn{2}{c|}{ Nível } & Vila Cardoso & Gameleira & Jacunã & Piaus & Taquari & Lajinha & Média \\
\hline \multirow{3}{*}{1} & Quant & 17 & 26 & 5 & 3 & 2 & 2 & $\mathbf{5 5}$ \\
\cline { 2 - 9 } & $\%$ & 45,9 & 52,0 & 9,1 & 27,3 & 100,0 & 12,5 & $\mathbf{3 2 , 2}$ \\
\hline \multirow{3}{*}{2} & Quant & & 24 & 19 & 0 & 0 & 14 & 57 \\
\cline { 2 - 9 } & $\%$ & 0,0 & 48,0 & 34,5 & 0,0 & 0,0 & 87,5 & $\mathbf{3 3 , 3}$ \\
\hline \multirow{3}{*}{3} & Quant & 20 & 0 & 31 & 8 & 0 & & 59 \\
\cline { 2 - 9 } & $\%$ & 54,1 & 0,0 & 56,4 & 72,7 & 0,0 & 0,0 & $\mathbf{3 4 , 5}$ \\
\hline \multirow{3}{*}{ TOTAL } & $\%$ & $\mathbf{3 7}$ & $\mathbf{5 0}$ & $\mathbf{5 5}$ & $\mathbf{1 1}$ & $\mathbf{2}$ & $\mathbf{1 6}$ & $\mathbf{1 7 1}$ \\
\cline { 2 - 4 } & $\mathbf{1 0 0 , 0}$ & $\mathbf{1 0 0 , 0}$ & $\mathbf{1 0 0 , 0}$ & $\mathbf{1 0 0 , 0}$ & $\mathbf{1 0 0 , 0}$ & $\mathbf{1 0 0 , 0}$ & $\mathbf{1 0 0 , 0}$ \\
\end{tabular}

Tabela 65 Frequência de local de lavagem das roupas depois do saneamento, segundo níveis de saneamento e localidades do semi-árido baiano, 2002.

\begin{tabular}{|c|c|c|c|c|c|c|c|c|}
\hline \multicolumn{2}{|c|}{ Nível } & Vila Cardoso & Gameleira & Jacunã & Piaus & Taquari & Lajinha & Média \\
\hline \multirow[b]{2}{*}{1} & Quant & 25 & 50 & 23 & 24 & 6 & 5 & 133 \\
\hline & $\%$ & 67,6 & 100,0 & 95,8 & 70,6 & 60,0 & 31,3 & 77,8 \\
\hline \multirow[b]{2}{*}{2} & Quant & 12 & 0 & 1 & 10 & 4 & 11 & 38 \\
\hline & $\%$ & 32,4 & 0,0 & 4,2 & 29,4 & 40,0 & 68,8 & 22,2 \\
\hline \multirow[b]{2}{*}{3} & Quant & 0 & 0 & 0 & 0 & 0 & 0 & 0 \\
\hline & $\%$ & 0,0 & 0,0 & 0,0 & 0,0 & 0,0 & 0,0 & 0,0 \\
\hline & Quant & 37 & 50 & 24 & 34 & 10 & 16 & 171 \\
\hline TA & $\%$ & 100,0 & 100,0 & 100,0 & 100,0 & 100,0 & 100,0 & 100,0 \\
\hline
\end{tabular}

Tabela 66 Frequência de local de banho antes do saneamento, segundo níveis de saneamento e localidades do semi-árido baiano, 2002.

\begin{tabular}{c|l|c|c|c|c|c|c|c}
\hline \multicolumn{2}{c|}{ Nível } & Vila Cardoso & Gameleira & Jacunã & Piaus & Taquari & Lajinha & Média \\
\hline \multirow{3}{*}{1} & Quant & 13 & 41 & 15 & 8 & 4 & 3 & 84 \\
\cline { 2 - 9 } & $\%$ & 35,1 & 82,0 & 30,6 & 53,3 & 100,0 & 18,8 & $\mathbf{4 9 , 1}$ \\
\hline \multirow{3}{*}{2} & Quant & 4 & 9 & 9 & 1 & 0 & 13 & 36 \\
\cline { 2 - 9 } & $\%$ & 10,8 & 18,0 & 18,4 & 6,7 & 0,0 & 81,3 & $\mathbf{2 1 , 1}$ \\
\hline \multirow{3}{*}{3} & Quant & 20 & 0 & 25 & 6 & 0 & 0 & 51 \\
\cline { 2 - 9 } TOTAL & 54,1 & 0,0 & 51,0 & 40,0 & 0,0 & 0,0 & $\mathbf{2 9 , 8}$ \\
\cline { 2 - 10 } & Quant & $\mathbf{3 7}$ & $\mathbf{5 0}$ & $\mathbf{4 9}$ & $\mathbf{1 5}$ & $\mathbf{4}$ & $\mathbf{1 6}$ & $\mathbf{1 7 1}$ \\
\hline & $\mathbf{1 0 0 , 0}$ & $\mathbf{1 0 0 , 0}$ & $\mathbf{1 0 0 , 0}$ & $\mathbf{1 0 0 , 0}$ & $\mathbf{1 0 0 , 0}$ & $\mathbf{1 0 0 , 0}$ & $\mathbf{1 0 0 , 0}$
\end{tabular}

Tabela 67 Frequência de local de banho depois do saneamento, segundo níveis de saneamento e localidades do semi-árido baiano, 2002.

\begin{tabular}{|c|c|c|c|c|c|c|c|c|}
\hline \multicolumn{2}{|c|}{ Nível } & Vila Cardoso & Gameleira & Jacunã & Piaus & Taquari & Lajinha & Média \\
\hline \multirow[b]{2}{*}{1} & Quant & 33 & 50 & 22 & 32 & 9 & 13 & 159 \\
\hline & $\%$ & 89,2 & 100,0 & 84,6 & 97,0 & 81,8 & 92,9 & 93,0 \\
\hline \multirow[b]{2}{*}{2} & Quant & 3 & 0 & 2 & 0 & 0 & 1 & 6 \\
\hline & $\%$ & 8,1 & 0,0 & 7,7 & 0,0 & 0,0 & 7,1 & 3,5 \\
\hline \multirow{3}{*}{3} & Quant & 1 & 0 & 2 & 1 & 2 & 0 & 6 \\
\hline & $\%$ & 2,7 & 0,0 & 7,7 & 3,0 & 18,2 & 0,0 & 3,5 \\
\hline & Quant & 37 & 50 & 26 & 33 & 11 & 14 & 171 \\
\hline TOTAL & $\%$ & 100,0 & 100,0 & 100,0 & 100,0 & 100,0 & 100,0 & 100,0 \\
\hline
\end{tabular}


Tabela 68 Frequência de local utilizado para defecar antes do saneamento, segundo níveis de saneamento e localidades do semi-árido baiano, 2002.

\begin{tabular}{c|c|c|c|c|c|c|c|c}
\hline \multicolumn{2}{c|}{ Nível } & Vila Cardoso & Gameleira & Jacunã & Piaus & Taquari & Lajinha & Média \\
\hline \multirow{3}{*}{1} & Quant & 29 & 42 & 17 & 25 & 6 & 12 & 131 \\
\cline { 2 - 9 } & $\%$ & 78,4 & 84,0 & 70,8 & 73,5 & 60,0 & 75,0 & $\mathbf{7 6 , 6}$ \\
\hline \multirow{3}{*}{2} & Quant & 1 & 0 & 1 & 1 & 0 & 1 & 4 \\
\cline { 2 - 9 } & $\%$ & 2,7 & 0,0 & 4,2 & 2,9 & 0,0 & 6,3 & $\mathbf{2 , 3}$ \\
\hline \multirow{3}{*}{3} & Quant & 7 & 8 & 6 & 8 & 4 & 3 & 36 \\
\cline { 2 - 9 } & $\%$ & 18,9 & 16,0 & 25,0 & 23,5 & 40,0 & 18,8 & $\mathbf{2 1 , 1}$ \\
\hline \multirow{2}{*}{ TOTAL } & Quant & $\mathbf{3 7}$ & $\mathbf{5 0}$ & $\mathbf{2 4}$ & $\mathbf{3 4}$ & $\mathbf{1 0}$ & $\mathbf{1 6}$ & $\mathbf{1 7 1}$ \\
\cline { 2 - 9 } & $\mathbf{1 0 0 , 0}$ & $\mathbf{1 0 0 , 0}$ & $\mathbf{1 0 0 , 0}$ & $\mathbf{1 0 0 , 0}$ & $\mathbf{1 0 0 , 0}$ & $\mathbf{1 0 0 , 0}$ & $\mathbf{1 0 0 , 0}$
\end{tabular}

Tabela 69 Frequência de local utilizado para defecar depois do saneamento, segundo níveis de saneamento e localidades do semi-árido baiano, 2002.

\begin{tabular}{c|l|c|c|c|c|c|c|c}
\hline \multicolumn{2}{c|}{ Nível } & Vila Cardoso & Gameleira & Jacunã & Piaus & Taquari & Lajinha & Média \\
\hline \multirow{3}{*}{1} & Quant & 35 & 49 & 23 & 34 & 10 & 15 & 166 \\
\cline { 2 - 10 } & $\%$ & 100,0 & 100,0 & 95,8 & 100,0 & 100,0 & 93,8 & $\mathbf{9 8 , 8}$ \\
\hline \multirow{3}{*}{2} & Quant & 0 & 0 & 1 & 0 & 0 & 0 & 1 \\
\cline { 2 - 9 } & $\%$ & 0,0 & 0,0 & 4,2 & 0,0 & 0,0 & 0,0 & $\mathbf{0 , 6}$ \\
\hline \multirow{3}{*}{3} & Quant & 0 & 0 & 0 & 0 & 0 & 1 & 1 \\
\cline { 2 - 9 } TOTAL & 0,0 & 0,0 & 0,0 & 0,0 & 0,0 & 6,3 & $\mathbf{0 , 6}$ \\
\cline { 2 - 10 } & $\%$ & $\mathbf{3 5}$ & $\mathbf{4 9}$ & $\mathbf{2 4}$ & $\mathbf{3 4}$ & $\mathbf{1 0}$ & $\mathbf{1 6}$ & $\mathbf{1 6 8}$ \\
\cline { 2 - 9 } & $\mathbf{1 0 0 , 0}$ & $\mathbf{1 0 0 , 0}$ & $\mathbf{1 0 0 , 0}$ & $\mathbf{1 0 0 , 0}$ & $\mathbf{1 0 0 , 0}$ & $\mathbf{1 0 0 , 0}$ & $\mathbf{1 0 0 , 0}$
\end{tabular}

Tabela 70 Frequência de práticas sanitárias antes do saneamento, segundo níveis de saneamento e localidades do semi-árido baiano, 2002.

\begin{tabular}{c|l|c|c|c|c|c|c|c}
\hline \multicolumn{2}{c|}{ Nível } & Vila Cardoso & Gameleira & Jacunã & Piaus & Taquari & Lajinha & Média \\
\hline \multirow{3}{*}{1} & Quant & 110 & 175 & 58 & 65 & 22 & 32 & $\mathbf{4 6 2}$ \\
\cline { 2 - 9 } & $\%$ & 29,7 & 35,1 & 19,6 & 21,8 & 25,6 & 20,1 & $\mathbf{2 7 , 0}$ \\
\hline \multirow{3}{*}{2} & Quant & 120 & 225 & 130 & 138 & 38 & 72 & $\mathbf{7 2 3}$ \\
\cline { 2 - 9 } & $\%$ & 32,4 & 45,1 & 43,9 & 46,3 & 44,2 & 45,3 & $\mathbf{4 2 , 3}$ \\
\hline \multirow{3}{*}{3} & Quant & 140 & 99 & 108 & 95 & 26 & 55 & $\mathbf{5 2 3}$ \\
\cline { 2 - 9 } & $\%$ & 37,8 & 19,8 & 36,5 & 31,9 & 30,2 & 34,6 & $\mathbf{3 0 , 6}$ \\
\hline \multirow{2}{*}{ TOTAL } & Quant & $\mathbf{3 7 0}$ & $\mathbf{4 9 9}$ & $\mathbf{2 9 6}$ & $\mathbf{2 9 8}$ & $\mathbf{8 6}$ & $\mathbf{1 5 9}$ & $\mathbf{1 . 7 0 8}$ \\
\cline { 2 - 10 } & $\mathbf{1 0 0 , 0}$ & $\mathbf{1 0 0 , 0}$ & $\mathbf{1 0 0 , 0}$ & $\mathbf{1 0 0 , 0}$ & $\mathbf{1 0 0 , 0}$ & $\mathbf{1 0 0 , 0}$ & $\mathbf{1 0 0 , 0}$
\end{tabular}

Tabela 71 Frequência de práticas sanitárias depois do saneamento segundo níveis de saneamento e localidades do semi-árido baiano, 2002.

\begin{tabular}{c|l|c|c|c|c|c|c|c}
\hline \multicolumn{2}{c|}{ Nível } & Vila Cardoso & Gameleira & Jacunã & Piaus & Taquari & Lajinha & Média \\
\hline \multirow{2}{*}{1} & Quant & 230 & 338 & 144 & 202 & 65 & 82 & $\mathbf{1 0 6 1}$ \\
\cline { 2 - 9 } & $\%$ & 70,6 & 75,8 & 66,7 & 67,3 & 73,9 & 58,2 & $\mathbf{6 9 , 9}$ \\
\hline \multirow{3}{*}{2} & Quant & 70 & 104 & 56 & 75 & 19 & 53 & $\mathbf{3 7 7}$ \\
\cline { 2 - 9 } & $\%$ & 21,5 & 23,3 & 25,9 & 25,0 & 21,6 & 37,6 & $\mathbf{2 4 , 9}$ \\
\hline \multirow{3}{*}{3} & Quant & 26 & 4 & 16 & 23 & 4 & 6 & $\mathbf{7 9}$ \\
\cline { 2 - 9 } & $\%$ & 8,0 & 0,9 & 7,4 & 7,7 & 4,5 & 4,3 & $\mathbf{5 , 2}$ \\
\hline \multirow{2}{*}{ TOTAL } & Quant & $\mathbf{3 2 6}$ & $\mathbf{4 4 6}$ & $\mathbf{2 1 6}$ & $\mathbf{3 0 0}$ & $\mathbf{8 8}$ & $\mathbf{1 4 1}$ & $\mathbf{1 . 5 1 7}$ \\
\cline { 2 - 10 } & $\mathbf{1 0 0 , 0}$ & $\mathbf{1 0 0 , 0}$ & $\mathbf{1 0 0 , 0}$ & $\mathbf{1 0 0 , 0}$ & $\mathbf{1 0 0 , 0}$ & $\mathbf{1 0 0 , 0}$ & $\mathbf{1 0 0 , 0}$
\end{tabular}


Tabela 72 Número de crianças com menos de 2 anos e crianças com diarréia em Vila Cardoso (Caém). No período de abril de 1999 a setembro de 2000.

\begin{tabular}{c|c|c|c}
\hline \multirow{2}{*}{ MÊs } & \multirow{2}{*}{$\begin{array}{c}\text { Total } \\
\text { de }\end{array}$} & \multicolumn{2}{|c}{ Crianças com diarréia } \\
\cline { 3 - 4 } crianças & Quantidade & $\%$ \\
\hline Abr/99 & 84 & 2 & 2,38 \\
\hline Mai/99 & 51 & 0 & 0,00 \\
\hline Jun/99 & 47 & 2 & 4,26 \\
\hline Jul/99 & 43 & 3 & 6,98 \\
\hline Ago/99 & 64 & 0 & 0,00 \\
\hline Set/99 & 52 & 2 & 3,85 \\
\hline Out/99 & 48 & 1 & $\mathbf{2 , 0 8}$ \\
\hline Nov/99 & 43 & 1 & $\mathbf{2 , 3 3}$ \\
\hline Dez/99 & 44 & 1 & $\mathbf{2 , 2 7}$ \\
\hline Total & $\mathbf{4 7 6}$ & $\mathbf{1 2}$ & $\mathbf{2 , 5 2}$ \\
\hline Jan/00 & $\mathbf{4 5}$ & $\mathbf{1}$ & $\mathbf{2 , 2 2}$ \\
\hline Fev/00 & $\mathbf{5 8}$ & $\mathbf{0}$ & $\mathbf{0 , 0 0}$ \\
\hline Mar/00 & $\mathbf{6 5}$ & $\mathbf{0}$ & $\mathbf{0 , 0 0}$ \\
\hline Abr/00 & $\mathbf{4 8}$ & $\mathbf{0}$ & $\mathbf{0 , 0 0}$ \\
\hline Mai/00 & $\mathbf{3 3}$ & $\mathbf{1}$ & $\mathbf{3 , 0 3}$ \\
\hline Jun/00 & $\mathbf{5 8}$ & $\mathbf{0}$ & $\mathbf{0 , 0 0}$ \\
\hline Jul/00 & $\mathbf{6 1}$ & $\mathbf{1}$ & $\mathbf{1 , 6 4}$ \\
\hline Ago/00 & $\mathbf{8 5}$ & $\mathbf{1}$ & $\mathbf{1 , 1 8}$ \\
\hline Set/00 & $\mathbf{7 1}$ & $\mathbf{1}$ & $\mathbf{1 , 4 1}$ \\
\hline Total & $\mathbf{5 2 4}$ & $\mathbf{5}$ & $\mathbf{0 , 9 5}$ \\
\hline Munn & & & \\
\hline
\end{tabular}

Fonte: Secretaria Municipal de Saúde de Caém/SIAB

observação: Os valores em negrito referem-se ao periodo após a implantação do sistema de saneamento. 
Tabela 73 Número de crianças com menos de 2 anos e crianças com diarréia nas demais localidades do município de Caém. No período de abril de 1999 a setembro de 2000.

\begin{tabular}{|c|c|c|c|}
\hline \multirow{2}{*}{ MÊS } & \multirow{2}{*}{$\begin{array}{c}\text { Total } \\
\text { de } \\
\text { crianças }\end{array}$} & \multicolumn{2}{|c|}{ Crianças com diarréia } \\
\hline & & Quantidade & $\%$ \\
\hline Abr/99 & 133 & 5 & 3,76 \\
\hline Mai/99 & 112 & 1 & 0,89 \\
\hline Jun/99 & 165 & 2 & 1,21 \\
\hline Jul/99 & 183 & 1 & 0,55 \\
\hline Ago/99 & 170 & 4 & 2,35 \\
\hline Set/99 & 171 & 4 & 2,34 \\
\hline Out/99 & 182 & 2 & 1,10 \\
\hline Nov/99 & 169 & 3 & 1,78 \\
\hline Dez/99 & 129 & 1 & 0,78 \\
\hline Total & 1.414 & 23 & 1,63 \\
\hline Jan/00 & 179 & 1 & 0,56 \\
\hline Fev/00 & 192 & 2 & 1,04 \\
\hline Mar/00 & 132 & 1 & 0,76 \\
\hline Abr/00 & 181 & 4 & 2,21 \\
\hline Mai/00 & 178 & 3 & 1,69 \\
\hline Jun/00 & 164 & 4 & 2,44 \\
\hline Jul/00 & 124 & 0 & 0,00 \\
\hline Ago/00 & 196 & 2 & 1,02 \\
\hline Set/00 & 180 & 0 & 0,00 \\
\hline Total & 1.526 & 17 & 1,11 \\
\hline
\end{tabular}

Fonte: Secretaria Municipal de Saúde de Caém/SIAB

Observação: Os valores em negrito referem-se ao período após a implantação do sistema de saneamento. 
Tabela 74 Número de crianças com menos de 2 anos e crianças com diarréia em Gameleira (Jaguarari). No período de maio de 2001 a outubro de 2002.

\begin{tabular}{|c|c|c|c|}
\hline \multirow{2}{*}{ MÊS } & \multirow{2}{*}{$\begin{array}{c}\begin{array}{c}\text { Total } \\
\text { de } \\
\text { crianças }\end{array} \\
\text {. }\end{array}$} & \multicolumn{2}{|c|}{ Crianças com diarréia } \\
\hline & & Quantidade & $\%$ \\
\hline Mai/01 & 68 & 9 & 13,24 \\
\hline Jun/01 & 83 & 10 & 12,05 \\
\hline Jul/01 & 81 & 9 & 11,11 \\
\hline Ago/01 & 63 & 14 & 22,22 \\
\hline Set/01 & 66 & 10 & 15,15 \\
\hline Out/01 & 66 & 7 & 10,61 \\
\hline Nov/01 & 69 & 7 & 10,14 \\
\hline Dez/01 & 59 & 6 & 10,17 \\
\hline Total & 555 & 72 & 12,97 \\
\hline Jan/02 & 85 & 15 & 17,65 \\
\hline Fev/02 & 75 & 5 & 6,67 \\
\hline Mar/02 & 62 & 7 & 11,29 \\
\hline Abr/02 & 62 & 6 & 1,47 \\
\hline Mai/02 & 68 & 1 & 1,47 \\
\hline Jun/02 & 54 & 4 & 7,41 \\
\hline Jul/02 & 40 & 5 & 12,50 \\
\hline Ago/02 & 58 & 8 & 13,79 \\
\hline Set/02 & 63 & 8 & 12,70 \\
\hline Out/02 & 58 & 3 & 5,17 \\
\hline Total & 625 & 62 & 9,92 \\
\hline
\end{tabular}
implantação do sistema de saneamento. 
Tabela 75 Número de crianças com menos de 2 anos e crianças com diarréia em Jacunã (Jaguarari). No período de maio de 2001 a outubro de 2002.

\begin{tabular}{c|c|c|c}
\hline \multirow{2}{*}{ MÊs } & \multirow{2}{*}{$\begin{array}{c}\text { Total } \\
\text { de } \\
\text { crianças }\end{array}$} & \multicolumn{2}{|c}{ Crianças com diarréia } \\
\cline { 3 - 4 } & 72 & 9 & $\%$ \\
\hline Mai/01 & Quantidade & 12,50 \\
\hline Jun/01 & 30 & 10 & 33,33 \\
\hline Jul/01 & 67 & 12 & 17,91 \\
\hline Ago/01 & 43 & 7 & 16,28 \\
\hline Set/01 & 69 & 11 & 15,94 \\
\hline Out/01 & 68 & 25 & 36,76 \\
\hline Nov/01 & 70 & 11 & 15,71 \\
\hline Dez/01 & 37 & 2 & 5,41 \\
\hline Total & $\mathbf{4 5 6}$ & $\mathbf{8 7}$ & $\mathbf{1 9 , 0 8}$ \\
\hline Jan/02 & $\mathbf{6 4}$ & $\mathbf{7}$ & $\mathbf{1 0 , 9 4}$ \\
\hline Fev/02 & $\mathbf{6 8}$ & $\mathbf{1 9}$ & $\mathbf{2 7 , 9 4}$ \\
\hline Mar/02 & $\mathbf{6 4}$ & $\mathbf{1 1}$ & $\mathbf{1 7 , 1 9}$ \\
\hline Abr/02 & $\mathbf{6 2}$ & $\mathbf{8}$ & $\mathbf{1 2 , 9 0}$ \\
\hline Mai/02 & $\mathbf{6 5}$ & $\mathbf{7}$ & $\mathbf{1 0 , 7 7}$ \\
\hline Jun/02 & $\mathbf{6 2}$ & $\mathbf{4}$ & $\mathbf{6 , 4 5}$ \\
\hline Jul/02 & $\mathbf{6 3}$ & $\mathbf{1 1}$ & $\mathbf{1 7 , 4 6}$ \\
\hline Ago/02 & $\mathbf{6 7}$ & $\mathbf{6}$ & $\mathbf{8 , 9 6}$ \\
\hline Set/02 & $\mathbf{3 4}$ & $\mathbf{3}$ & $\mathbf{8 , 8 2}$ \\
\hline Out/02 & $\mathbf{3 7}$ & $\mathbf{0}$ & $\mathbf{0 , 0 0}$ \\
\hline Total & $\mathbf{5 8 6}$ & $\mathbf{7 6}$ & $\mathbf{1 2 , 9 7}$ \\
\hline & & & \\
\hline & & & \\
\hline
\end{tabular}

Fonte: Secretaria Municipal de Saúde de Jaguarari/SIAB

Observação: Os valores em negrito referem-se ao período após a implantação do sistema de saneamento. 
Tabela 76 Número de crianças com menos de 2 anos e crianças com diarréia nas demais localidades do município de Jaguarari. No período de maio de 2001 a outubro de 2002.

\begin{tabular}{c|c|c|c}
\hline \multirow{2}{*}{ MÊs } & \multirow{2}{*}{$\begin{array}{c}\text { Total de } \\
\text { crianças }\end{array}$} & \multicolumn{2}{|c}{ Crianças com diarréia } \\
\cline { 3 - 4 } & Quanitidade & $\%$ \\
\hline Mai/01 & 488 & 24 & 4,92 \\
\hline Jun/01 & 510 & 56 & 10,98 \\
\hline Jul/01 & 486 & 27 & 5,56 \\
\hline Ago/01 & 516 & 13 & 2,52 \\
\hline Set/01 & 584 & 29 & 4,97 \\
\hline Out/01 & 486 & 26 & 5,35 \\
\hline Nov/01 & 530 & 25 & 4,72 \\
\hline Dez/01 & 447 & 29 & 6,49 \\
\hline Total & $\mathbf{4 . 0 4 7}$ & $\mathbf{2 2 9}$ & $\mathbf{5 , 6 6}$ \\
\hline Jan/02 & $\mathbf{5 2 0}$ & $\mathbf{2 9}$ & $\mathbf{5 , 5 8}$ \\
\hline Fev/02 & $\mathbf{4 6 6}$ & $\mathbf{4 2}$ & $\mathbf{9 , 0 1}$ \\
\hline Mar/02 & $\mathbf{5 0 4}$ & $\mathbf{2 3}$ & $\mathbf{4 , 5 6}$ \\
\hline Abr/02 & $\mathbf{5 0 6}$ & $\mathbf{2 7}$ & $\mathbf{5 , 3 4}$ \\
\hline Mai/02 & $\mathbf{4 9 9}$ & $\mathbf{2 4}$ & $\mathbf{4 , 8 1}$ \\
\hline Jun/02 & $\mathbf{5 2 3}$ & $\mathbf{2 9}$ & $\mathbf{5 , 5 4}$ \\
\hline Jul/02 & $\mathbf{5 2 9}$ & $\mathbf{1 5}$ & $\mathbf{2 , 8 4}$ \\
\hline Ago/02 & $\mathbf{5 6 5}$ & $\mathbf{3 5}$ & $\mathbf{6 , 1 9}$ \\
\hline Set/02 & $\mathbf{5 1 8}$ & $\mathbf{1 9}$ & $\mathbf{3 , 6 7}$ \\
\hline Out/02 & $\mathbf{5 2 0}$ & $\mathbf{3 6}$ & $\mathbf{6 , 9 2}$ \\
\hline Total & $\mathbf{5 . 1 5 0}$ & $\mathbf{2 7 9}$ & $\mathbf{5 , 4 2}$ \\
\hline & & & \\
\hline & & 29 & \\
\hline
\end{tabular}

Fonte: Secretaria Municipal de Saúde de Jaguarari/SIAB

Observação: Os valores em negrito referem-se ao período após a implantação do sistema de saneamento. 
Tabela 77 Número de crianças com menos de 2 anos e crianças com diarréia em Lajinha (Pindobaçu). No período de setembro de 1999 a dezembro de 2001.

\begin{tabular}{|c|c|c|c|}
\hline \multirow{2}{*}{ MÊS } & \multirow{2}{*}{$\begin{array}{c}\text { Total } \\
\text { de } \\
\text { crianças }\end{array}$} & \multicolumn{2}{|c|}{ Crianças com diarréia } \\
\hline & & Quantidade & $\%$ \\
\hline Set/99 & 19 & 0 & 0,00 \\
\hline Out/99 & 35 & 9 & 25,71 \\
\hline Nov/99 & 18 & 2 & 11,11 \\
\hline Dez/99 & 17 & 1 & 5,88 \\
\hline Total & 89 & 12 & 13,48 \\
\hline $\operatorname{Jan} / 00$ & 15 & 0 & 0,00 \\
\hline $\mathrm{Fev} / 00$ & 16 & 2 & 12,50 \\
\hline Mar/00 & 33 & 3 & 9,09 \\
\hline $\mathrm{Abr} / 00$ & 26 & 0 & 0,00 \\
\hline Marl00 & 33 & 2 & 6,06 \\
\hline Jun/00 & 24 & 5 & 20,83 \\
\hline Jul/00 & 30 & 2 & 6,67 \\
\hline Ago/00 & 37 & 5 & 13,51 \\
\hline Set/00 & 31 & 1 & 3,23 \\
\hline Out/00 & 12 & 1 & 8,33 \\
\hline Nov/00 & 11 & 1 & 9,09 \\
\hline Dez/00 & 11 & 1 & 9,09 \\
\hline Total & 279 & 23 & 8,24 \\
\hline Jan/01 & 19 & 2 & 10,53 \\
\hline Fev/01 & 14 & 0 & 0,00 \\
\hline Mar/01 & 9 & 1 & 11,11 \\
\hline Abr/01 & 17 & 1 & 5,88 \\
\hline Mai/01 & 10 & 0 & 0,00 \\
\hline Jun/01 & 13 & 1 & 7,69 \\
\hline Jul/01 & 15 & 1 & 6,67 \\
\hline Ago/01 & 14 & 0 & 0,00 \\
\hline Set/01 & 11 & 1 & 9,09 \\
\hline Out/01 & 10 & 0 & 0,00 \\
\hline Nov/01 & 10 & 1 & 10,00 \\
\hline Dez/01 & 11 & 2 & 18,18 \\
\hline Total & 153 & 10 & 6,54 \\
\hline
\end{tabular}

Fonte: Secretaria Municipal de Saúde de Pindobaçu/SIAB

Observação: Os valores em negrito referem-se ao período após a implantação do sistema de saneamento. 
Tabela 78 Número de crianças com menos de 2 anos e crianças com diarréia nas demais localidades do município de Pindobaçu. No período de setembro de 1999 a dezembro de 2001.

\begin{tabular}{|c|c|c|c|}
\hline \multirow{2}{*}{ MÊS } & \multirow{2}{*}{$\begin{array}{c}\text { Total } \\
\text { de } \\
\text { crianças }\end{array}$} & \multicolumn{2}{|c|}{ Crianças com diarréia } \\
\hline & & Quantidade & $\%$ \\
\hline set/99 & 536 & 89 & 16,60 \\
\hline out/99 & 608 & 90 & 14,80 \\
\hline nov/99 & 582 & 66 & 11,34 \\
\hline dez/99 & 485 & 54 & 11,13 \\
\hline Total & 294 & 40 & 13,53 \\
\hline jan/00 & 560 & 60 & 10,71 \\
\hline $\mathrm{fev} / 00$ & 616 & 59 & 9,58 \\
\hline $\mathrm{mar} / 00$ & 547 & 56 & 10,24 \\
\hline$a b r / 00$ & 662 & 42 & 6,34 \\
\hline $\mathrm{mai} / 00$ & 684 & 67 & 9,80 \\
\hline jun/00 & 670 & 55 & 8,21 \\
\hline jul/00 & 599 & 50 & 8,35 \\
\hline ago/00 & 600 & 42 & 7,00 \\
\hline set/00 & 448 & 26 & 5,80 \\
\hline out/00 & 560 & 40 & 7,14 \\
\hline nov/00 & 626 & 41 & 6,55 \\
\hline $\mathrm{dez} / 00$ & 546 & 25 & 4,58 \\
\hline Total & 337 & 26 & 7,66 \\
\hline jan/01 & 562 & 80 & 14,23 \\
\hline fev/01 & 485 & 27 & 5,57 \\
\hline Mar/01 & 279 & 22 & 7,89 \\
\hline Abr/01 & 525 & 45 & 8,57 \\
\hline Mai/01 & 168 & 33 & 19,64 \\
\hline Jun/01 & 541 & 38 & 7,02 \\
\hline jul/01 & 571 & 29 & 5,08 \\
\hline Ago/01 & 631 & 35 & 5,55 \\
\hline Set/01 & 465 & 22 & 4,73 \\
\hline Out/01 & 628 & 51 & 8,12 \\
\hline Nov/01 & 534 & 25 & 4,68 \\
\hline Dez/01 & 599 & 24 & 4,01 \\
\hline Total & 359 & 27 & 7,46 \\
\hline
\end{tabular}

Fonte: Secretaria Municipal de Saúde de Pindobaçu/SIAB

Observação: Os valores em negrito referem-se ao período após a implantação do sistema de saneamento. 
Tabela 79 Número de crianças com menos de 2 anos e crianças com diarréia nas localidades da pesquisa. No período de julho de 2001 a outubro de 2002.

\begin{tabular}{|c|c|c|c|}
\hline \multirow{2}{*}{ MÊS } & \multirow{2}{*}{$\begin{array}{c}\text { Total } \\
\text { de } \\
\text { crianças }\end{array}$} & \multicolumn{2}{|c|}{ Crianças com diarréia } \\
\hline & & Quantidade & $\%$ \\
\hline Jul/01 & 262 & 25 & 9,54 \\
\hline Ago/01 & 194 & 26 & 13,40 \\
\hline Set/01 & 213 & 24 & 11,27 \\
\hline Out/01 & 189 & 36 & 19,05 \\
\hline Nov/01 & 214 & 19 & 8,88 \\
\hline Dez/01 & 159 & 11 & 6,92 \\
\hline Total & 1.231 & 141 & 11,45 \\
\hline Jan/02 & 216 & 25 & 11,57 \\
\hline Fev/02 & 200 & 25 & 12,50 \\
\hline Mar/02 & 179 & 20 & 11,17 \\
\hline Abr/02 & 186 & 16 & 3,98 \\
\hline Mai/02 & 201 & 8 & 3,98 \\
\hline Jun/02 & 194 & 9 & 4,64 \\
\hline Jul/02 & 166 & 17 & 10,24 \\
\hline Ago/02 & 172 & 15 & 8,72 \\
\hline Set/02 & 166 & 12 & 7,23 \\
\hline Out/02 & 166 & 4 & 2,41 \\
\hline Total & 1.846 & 151 & 8,18 \\
\hline
\end{tabular}

Fonte: Secretarias Municipais de Saúde das cidades da pesquisa/SIAB

Observação: Os valores em negrito referem-se ao período após a implantação do sistema de saneamento. 
Tabela 80 Número de crianças com menos de 2 anos e crianças com diarréia nas demais localidades da pesquisa. No período de julho de 2001 a outubro de 2002.

\begin{tabular}{c|c|c|c}
\hline \multirow{2}{*}{ MÊS } & \multirow{2}{*}{$\begin{array}{c}\text { Total } \\
\text { de } \\
\text { crianças }\end{array}$} & \multicolumn{2}{|c}{ Crianças com diarréia } \\
\cline { 3 - 4 } & Quantidade & $\%$ \\
\hline Jul/01 & 1.218 & 82 & 6,73 \\
\hline Ago/01 & 1.228 & 56 & 4,56 \\
\hline Set/01 & 1.197 & 57 & 4,76 \\
\hline Out/01 & 1.229 & 67 & 5,45 \\
\hline Nov/01 & 1.326 & 70 & 5,28 \\
\hline Dez/01 & 1.164 & 58 & 4,98 \\
\hline Total & $\mathbf{7 . 3 6 2}$ & $\mathbf{3 9 0}$ & $\mathbf{5 , 3 0}$ \\
\hline Jan/02 & $\mathbf{1 . 2 6 4}$ & $\mathbf{1 1 1}$ & $\mathbf{8 , 7 8}$ \\
\hline Fev/02 & $\mathbf{1 . 1 2 0}$ & $\mathbf{7 2}$ & $\mathbf{6 , 4 3}$ \\
\hline Mar/02 & $\mathbf{9 1 2}$ & $\mathbf{4 6}$ & $\mathbf{5 , 0 4}$ \\
\hline Abr/02 & $\mathbf{1 . 2 1 0}$ & $\mathbf{7 3}$ & $\mathbf{6 , 0 3}$ \\
\hline Mai/02 & $\mathbf{8 5 9}$ & $\mathbf{5 9}$ & $\mathbf{6 , 8 7}$ \\
\hline Jun/02 & $\mathbf{1 . 1 9 6}$ & $\mathbf{6 8}$ & $\mathbf{5 , 6 9}$ \\
\hline Jul/02 & $\mathbf{1 . 2 8 1}$ & $\mathbf{4 8}$ & $\mathbf{3 , 7 5}$ \\
\hline Ago/02 & $\mathbf{1 . 3 7 4}$ & $\mathbf{7 3}$ & $\mathbf{5 , 3 1}$ \\
\hline Set/02 & $\mathbf{1 . 1 4 7}$ & $\mathbf{4 5}$ & $\mathbf{3 , 9 2}$ \\
\hline Out/02 & $\mathbf{1 . 2 7 2}$ & $\mathbf{8 7}$ & $\mathbf{6 , 8 4}$ \\
\hline Total & $\mathbf{1 1 . 6 3 5}$ & $\mathbf{6 8 2}$ & $\mathbf{5 , 8 6}$ \\
\hline Tunisipas & Saúde das cidades da pesquisa/SIAB & \\
\hline
\end{tabular}

Fonte: Secretarias Municipais de Saúde das cidades da pesquisa/SIAB

Observação: Os valores em negrito referem-se ao período após a implantação do sistema de saneamento. 


\section{Apêndice F Tabelas de Análise Estatística}

Tabela 81 T-Test-Média antes e depois das variáveis da planilha.

Paired Samples Statistics

\begin{tabular}{|ll|r|r|r|r|}
\hline & & Mean & $\mathrm{N}$ & Std. Deviation & $\begin{array}{c}\text { Std. Error } \\
\text { Mean }\end{array}$ \\
\hline Pair & DIARANTE & 7,7400 & 4 & 4,3976 & 2,1988 \\
1 & DIARDEP & 6,1425 & 4 & 3,0411 & 1,5206 \\
Pair & CONSANTE & 23,1683 & 4 & 1,7029 &, 8514 \\
2 & CONSDEP & 67,6294 & 4 & 5,6743 & 2,8372 \\
Pair & ARMANTE & 9,140 & 6 & 8,432 & 3,442 \\
3 & ARMDEP & 65,933 & 6 & 23,879 & 9,748 \\
Pair & BEBEANTE & 2,534 & 6 & 5,001 & 2,042 \\
4 & BEBEDEP & 76,755 & 6 & 21,054 & 8,595 \\
Pair & TRATANTE & 15,816 & 6 & 17,628 & 7,196 \\
5 & TRATDEP & 61,780 & 6 & 20,058 & 8,188 \\
Pair & LAVANTE & 15,814 & 6 & 3,497 & 1,428 \\
6 & LAVADEP & 52,444 & 6 & 17,408 & 7,107 \\
Pair & UTENANTE & 31,615 & 6 & 9,131 & 3,728 \\
7 & UTENDEP & 51,853 & 6 & 19,700 & 8,042 \\
Pair & MAOSNATE & 31,167 & 6 & 10,307 & 4,208 \\
8 & MAODEP & 46,491 & 6 & 11,101 & 4,532 \\
Pair & ROUPANTE & 41,135 & 6 & 33,601 & 13,718 \\
9 & ROUPDEP & 70,873 & 6 & 25,182 & 10,280 \\
Pair & BANANTE & 53,305 & 6 & 31,758 & 12,965 \\
10 & BANDEP & 90,908 & 6 & 7,048 & 2,877 \\
Pair & DEFANTE & 73,624 & 6 & 8,069 & 3,294 \\
11 & DEFDEP & 100,000 & 6 &, 000 &, 000 \\
\hline
\end{tabular}

Nota:

1 Cada variável possui o nome que segue a ordem da planilha. Ou seja, diarante=diarréia antes e diardep=diarréia depois e assim para as demais variáveis.

2 A descrição das variáveis acima segue a ordem da planilha, começando pela diarréia até hábitos de defecar. 
A tabela 82 a seguir mostra o t- teste emparelhado aplicado para verificar se ocorreram mudanças nos aspectos considerados. Observa-se que a maioria das comparações foi estatisticamente significante, ao nivel de $5 \%$, ou seja, apresentou p-valor abaixo de 0,05 . Isto levou a rejeição da hipótese nula $(\mathrm{Ho})$ e confirmou a hipótese alternativa $(\mathrm{H} 1)$ do pesquisador, ou seja, que ocorreram mudanças de comportamento nas localidades após a introdução de um novo fator, a água.

Tabela 82 T-Test emparelhado.

\begin{tabular}{|c|c|c|c|c|c|c|c|c|c|}
\hline \multicolumn{10}{|c|}{ Paired Samples Test } \\
\hline & & \multicolumn{5}{|c|}{ Paired Differences } & \multirow[b]{3}{*}{$t$} & \multirow[b]{3}{*}{$d f$} & \multirow[b]{3}{*}{ Sig. (2-tailed } \\
\hline & & \multirow[b]{2}{*}{ Mean } & \multirow[b]{2}{*}{ Std. Deviation } & \multirow{2}{*}{$\begin{array}{c}\text { Std. Error } \\
\text { Mean }\end{array}$} & \multicolumn{2}{|c|}{$\begin{array}{c}95 \% \text { Confidence } \\
\text { Interval of the } \\
\text { Difference }\end{array}$} & & & \\
\hline & & & & & Lower & Upper & & & \\
\hline Pair 1 & DIARANTE-DIARDEP & 1.5975 & 1.7347 & .8673 & $-1,1628$ & 4,3578 & 1,842 & 3 &, 163 \\
\hline Pair 2 & CONSANTE - CONSDEP & $-44,4611$ & 7.0617 & 3,5308 & $-55,6978$ & $-33,2244$ & $-12,592$ & 3 &, 001 \\
\hline Pair 3 & ARMANTE - ARMDEP & $-56,794$ & 19,862 & 8,109 & $-77,637$ & $-35,950$ & $-7,004$ & 5 &, 001 \\
\hline Pair 4 & BEBEANTE - BEBEDEP & $-74,221$ & 20.195 & 8,245 & $.95,414$ & $-53,028$ & $-9,002$ & 5 &, 000 \\
\hline Pair 5 & TRATANTE - TRATDEP & $-45,964$ & 21,911 & 8,945 & $-68,959$ & $-22,970$ & $-5,138$ & 5 &, 004 \\
\hline Pair 6 & LAVANTE - LAVADEP & $-36,630$ & 16,469 & 6,723 & $-53,913$ & $-19,347$ & $-5,448$ & 5 &, 003 \\
\hline Pair 7 & UTENANTE - UTENDEP & $-20,238$ & 17,299 & 7,062 & $-38,392$ & $-2,084$ & $-2,866$ & 5 & ,035 \\
\hline Pair 8 & MAOSNATE - MAODEP & $-15,325$ & 4,523 & 1,847 & $-20,072$ & $-10,577$ & $-8,298$ & 5 &, 000 \\
\hline Pair 9 & ROUPANTE - ROUPDEP & $-29,738$ & 41,994 & 17,144 & $-73,808$ & 14,331 & $-1,735$ & 5 & .143 \\
\hline Pair 10 & BANANTE - BANDEP & $-37,603$ & 32,878 & 13,422 & $-72,106$ & $-3,100$ & $-2,802$ & 5 & .038 \\
\hline Pair 11 & DEFANTE - DEFDEP & $-26,376$ & 8,069 & 3.294 & $-34,845$ & $-17,908$ & $-8,007$ & 5 &, 000 \\
\hline
\end{tabular}

Nota:

1 t-test emparelhado para média considerando os valores antes (DIARANTE, CONSANTE etc) e depois (DIARDEP, CONSDEP etc). 
9 ANEXO 
Anexo A Laudo de análise de águas residuária 


\section{UNIVERSIDADE ESTADUAL DE FEIRA DE SANTANA}

Autorizada pelo Decreto Federal No 77.498 de 27104176

Reconhecida pela Portaria Ministerial № 874/86 de 19/12/86

DEPARTAMENTO DE TECNOLOGIA

LABORATÓRIOS

\section{EXAME BACTERIOLÓGICO DA ÁGUA}

CERT. No 18102

INTERESSADO: Projeto de Avaliaçăo da Eficiência de Estaçōes de Tratamento de Esgoto de Baixo Custo

DATA DA, COLETA: $16 / 07 / 2002$

PERIODO DO EXAME: 24 horas TEMPO-Bom

COLETOR: "O Interessado"

PROCEDÉNCIA: Efluente de Esgoto

LOCAL: Comunidade de Vla Cardoso - Capim Grosso - Ba

\begin{tabular}{|c|c|c|}
\hline LOCAL DA COLETA & $\begin{array}{l}\text { COLIFORME TOTAL } \\
\text { NMP } 1100 \mathrm{~mL} \\
\end{array}$ & $\begin{array}{c}\text { COLIFORME FECAL } \\
\text { NMP } 1100 \mathrm{~mL}\end{array}$ \\
\hline Entratla para os Taruyues & $23.0 \times 10^{6}$ & $23.0 \times 10^{5}$ \\
\hline Saida dos Tanques & $23.0 \times 10^{5}$ & $23,0 \times 10^{5}$ \\
\hline Saida do leikr ile Brita & $12.0 \times 10^{3}$ & $12.0 \times 10^{3}$ \\
\hline
\end{tabular}

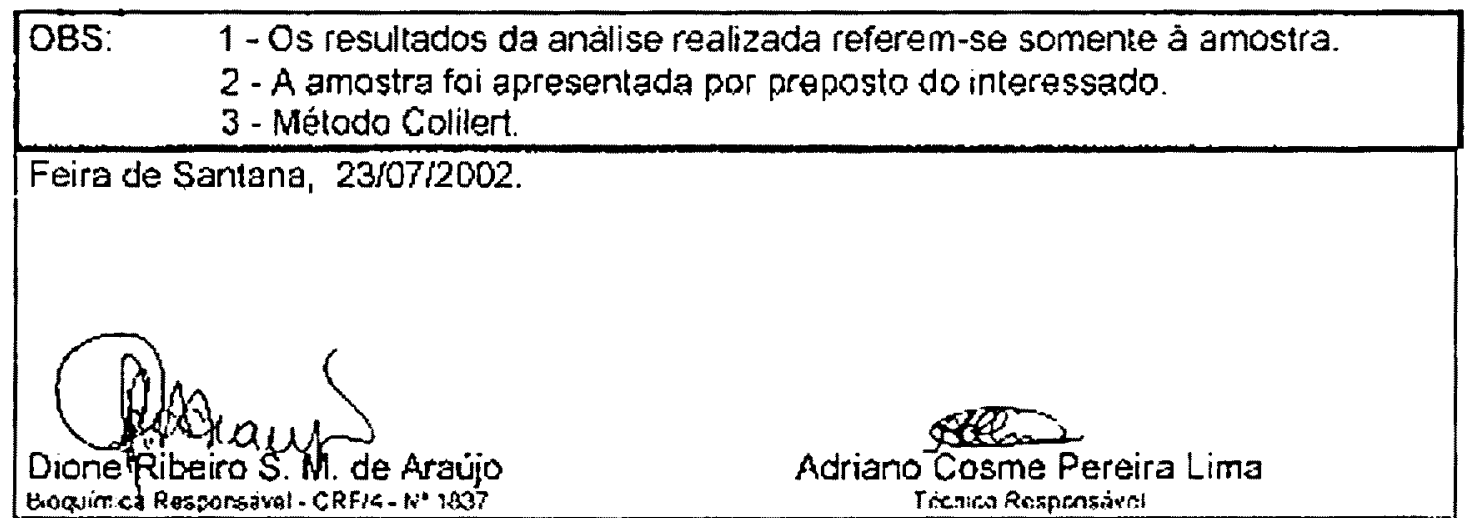

$\mathrm{Km}$ 03, BR 115 - CAMPUS UNIVERSITÁRIO - FEIRA DE SANTANAIBA $\rightarrow$ CEP $44031-460$ Telefone: (75) 224-8313 - FAX: (075)224-81 17-Tolax: (75) 2403 


\section{UNIVERSIDADE ESTADUAL DE FEIRA DE SANTANA \\ Autorizada pelo Decreto Foderal No 77.498 de 27/04/76. \\ Reconhecida pela Portaria Ministerial No $874 / 86$ de 19/12/86 \\ DEPARTAMENTO DE TECNOLOGIA \\ LABORATÓRIOS}

\section{EXAME PARA EFLUENTES}

CERT. No 181802

INTERESSADO: Projeto de Avaliação da Eficiencia de Estaçôes de Tratamento de Esgoto de Baixo Custo

DATA DA COLETA $1610 / 2002$

PERIODO DO EXAME:

COLETOR: "O Interessado"

PROCEDÉNCIA: Efluente de Esgoto

LOCAL: Comunidade de Vila Cardoso - Capim Grosso-Ba

\begin{tabular}{|c|c|c|}
\hline LOCAL DA COLETA & DQO & $\begin{array}{c}\text { DBO } \\
\text { mg/L DBO }\end{array}$ \\
\hline Entrada para os Tanques & 1500 & 780 \\
\hline Saida dos Tanilues & 500 & 320 \\
\hline Saidla do Leito de Brita & 250 & 80 \\
\hline
\end{tabular}

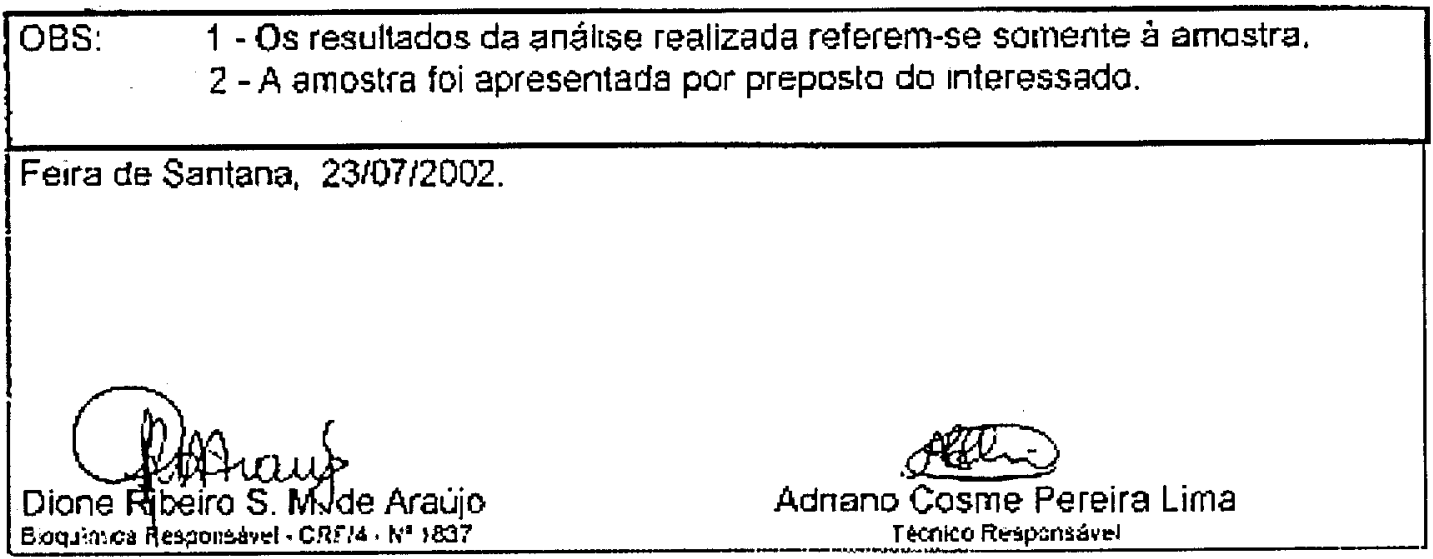

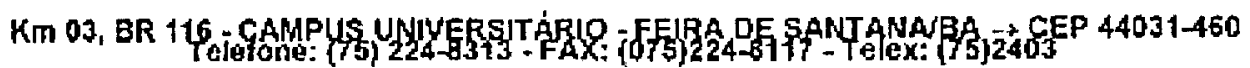




\section{UNIVERSIDADE ESTADUAL DE FEIRA DE SANTANA}

Autorizada pelo Decreto Federal No 77.498 de $27 / 04 / 76$

Reconhecida pola Portaria Ministerial № 874/86 de 19/12/86

DEPARTAMENTO DE TECNOLOGIA

LABORATÓRIOS

EXAME BACTERIOLOGICO DA ÁGUA

CERT. N $N^{\circ} 181 \mathrm{NO2}$

INTERESSADO: Projeto de Avaliaçăo da Eficiència de Estaçōes de Tratamento de Esgoto de Baixo Custo

DATA DA COLETA: $16 / 07 / 2002$

COLETOR: "O Interessado"

PROCEDÉNCIA: Efluente de Esgoto

LOCAL: Comunidade de Vila Cardoso - Capim Grosso - Ba

\begin{tabular}{|l|c|c|}
\hline LOCAL DA COLETA & $\begin{array}{c}\text { SOLIDOS TOTAIS } \\
\text { mgh }\end{array}$ & $\begin{array}{c}\text { SOLIDOS VOLÁTEIS } \\
\text { mgh }\end{array}$ \\
\hline Entrada para us Tanques & 2.260 & 1.196 \\
\hline Saida dos Tanizues & 1.818 & 1.130 \\
\hline Siida do Leito de Brita & 1.462 & 654 \\
\hline
\end{tabular}

OBS: $\quad 1$ - Os resultados da análise realizada referem-se somente a amostra.

2 - A amostra foi apresentada por preposto do interessado.

Feira de Santana, 23/07/2002.

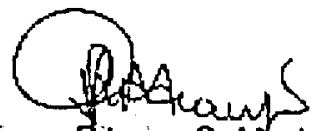

Dione Ribeiro S. M de Araújo

Bioquimica Responsdvel - CRT/4 - N० 1835

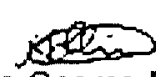

Adriano Cosme Pereira Lima Tónico Aasconstuel

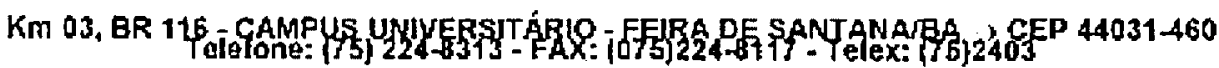

